ARGONNE CANCER RESEARCH HOSPITAL 950 EAST FIFTY.NINTH STREET - CHICAGO 37 - ILLINOIS

\title{
Semiannual Report to \\ THE ATOMIC ENERGY COMMISSION
}

SEPTEMBER 1962

LEON O. JACOBSON, M.D. Editor

MARGOT DOYLE, Ph.D. Associate Edifor

Facsimile Price \$ Microfilm Price \$

12.00 5,15

Available from the

Office of Technical Services

Department of Commerce

Washington 25, D. C.

\section{OPERATED BY THE UNIVERSITY OF CHICAGO UNDER}

\section{CONTRACT AT-(11-1)-69}




\section{DISCLAIMER}

This report was prepared as an account of work sponsored by an agency of the United States Government. Neither the United States Government nor any agency Thereof, nor any of their employees, makes any warranty, express or implied, or assumes any legal liability or responsibility for the accuracy, completeness, or usefulness of any information, apparatus, product, or process disclosed, or represents that its use would not infringe privately owned rights. Reference herein to any specific commercial product, process, or service by trade name, trademark, manufacturer, or otherwise does not necessarily constitute or imply its endorsement, recommendation, or favoring by the United States Government or any agency thereof. The views and opinions of authors expressed herein do not necessarily state or reflect those of the United States Government or any agency thereof. 


\section{DISCLAIMER}

Portions of this document may be illegible in electronic image products. Images are produced from the best available original document. 


\section{LEGAL NOTICE}

This report was prepared as an account of Government sponsored work. Neither the United States, nor the Commission, nor any person acting on behalf of the Commission:

A. Makes any warranty or representation, express or implied, with respect to the accuracy, completeness, or usefulness of the information contained in this report, or that the use of any information, apparatus, method, or process disclosed in this report may not infringe privately owned rights; or

B. Assumes any liabilities with respect to the use of, or for damages resulting from the use of any information, apparatus, method, or process disclosed in this report.

As used in the above, "person acting on behalf of the Commission" includes any employee or contractor of the Commission to the extent that such employee or contractor prepares, handles or distributes, or provides access to, any information pursuant to his employment or contract with the Commission.

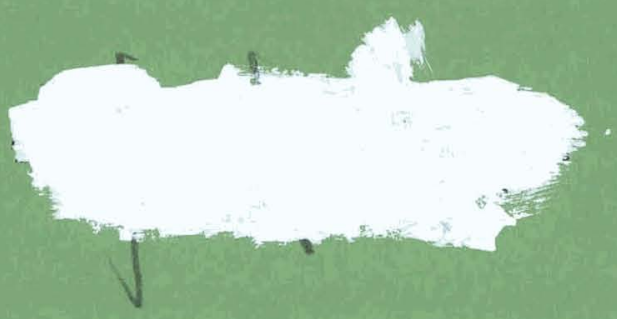


ACRH-18

ARGONNE CANCER RESEARCH HOSPITAL 950 EAST FIFTY-NINTH STREET - CHICAGO 37 . ILLINOIS

\section{Semiannual Report to \\ THE ATOMIC ENERGY COMMISSION}

SEPTEMBER 1962

LEON O. JACOBSON, M.D.

Editor

MARGOT DOYLE, Ph.D.

Associate Editor

OPERATED BY THE UNIVERSITY OF CHICAGO

UNDER

CONTRACT AT-(11-1)-69 


\section{TABLE OF CONTENTS}

A comparison of erythropoietin bioassays

R. L. DeGowin, D. Hofstra and C. W. Gurney . . . . . . . . . . . . .

The hypoxia-induced erythremic mouse, an erythropoietin bioassay animal

R. L. DeGowin, D. Hof stra and C. W. Gurney . . . . . . . . . . . .

Dynamics of the Stem Cell Compartment

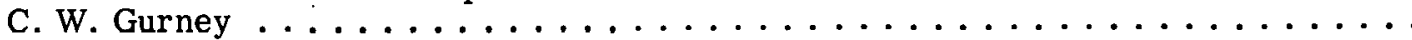

Hormonal factors influencing erythropoiesis in the hypophysectomized rat

J. W. Fisher, J. J. Crooks and P. H. Morse . . . . . . . . . . .

The lack of effect of plasma erythropoietin on formate incorporation into nucleic acids in vitro

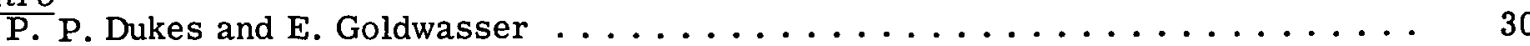

Further purification of sheep plasma erythropoietin

E. Goldwasser, W. F. White, and K. B. Taylor

Use of $\mathrm{I}^{125}$ as a protein label in immunology

F. W. Fitch, J. Winebright and P. V. Harper, Jr. .............

Antibody formation in the rat. I. Agglutinin response to particulate flagella from

Salmonella typhosa. II. Agglutinin response to soluble flagellin from Salmonella typhosa

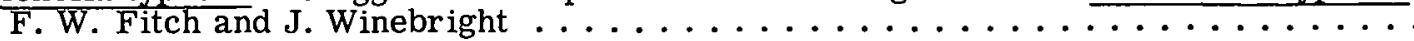

Combined inhibitory effect of antitumor antibody and an oncolytic virus on the solid

Ehrlich tumor

M. J. Stone, K. Dzoga and R. W. Wissler . . . . . . . . . . . . .

Techniques for parametrial irradiation using cobalt-60

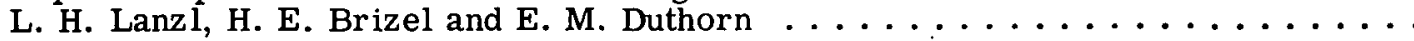

Preliminary observations on the use of six-hour $\mathrm{Tc}^{99 \mathrm{~m}}$ as a tracer in biology and medicine

P. V. Harper, G. Andros and K. Lathrop . . . . . . . . . . . .

Effect of RNA and yeast autolysate on experimental infection in irradiated and unirradiated mice

G. W. Hammond, S. K. Anderle and C. P. Miller . . . . . . . . . . .

Modification of the radiation effect on hair roots of the mouse by actinomycin $\mathrm{D}$

M. L. Griem and K. Ranniger . . . . . . . . . . . . . .

Modification of radiation response of tissue by colchicine: preliminary clinical evaluation

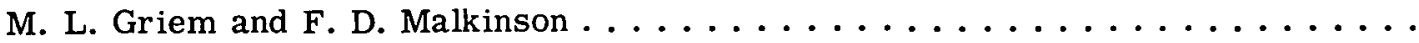

A new simplified method for perfusing dog skin

K. Adachi and D. C. Chow . . . ...................

Deoxyribonucleic acid microdetermination in human epidermis

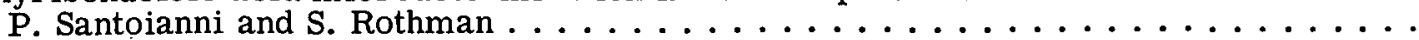

The biosynthesis of RNA: priming by polynucleotides

T. Nakamoto and S. B. Weiss . .................... 
The secondary structure of complementary RNA

E. P. Geiduschek, J. W. Moohr and S. B. Weiss . . . . . . . . . . . .

Steroid pyrogen studies in laboratory and domestic animals

R. H. Palmer, B. Ratkovitz and A. Kappas .........

Pyrogenic and inflammatory properties of certain bile acids in man

R. H. Palmer, P. B. Glickman and A. Kappas . . . . . . . .

Parathyroid hormone and whole body oxidation of glucose, pyruvate and citrate in the intact rat

J. L. Spratt and Gar Bo Ho . . . . . . . . . . . . . . . .

Peptide synthesis in bone marrow: insulin and thyroxine effects

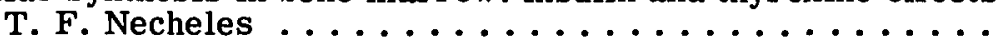

Biochemical studies on spontaneous carcinogenesis: in vivo effects of hormonal changes on $\mathrm{C}_{3} \mathrm{H}$ mice bearing hormone-dependent mammary carcinoma

G. T. Okita and E. Ezz . . . . . . . . . . . . . . . . .

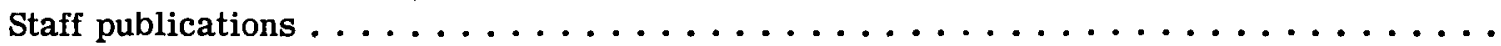




\section{A COMPARISON OF ERYTHROPOIETIN BIOASSAYS*}

By

R. L. DeGowin ${ }^{\dagger}$ D. Hof stra and C. W. Gurney ${ }^{\ddagger}$

Attempts to explain the mechanism by which the body reconstitutes its red blood cell mass after hemorrhage have led to the discovery of a humoral stimulant of erythropoiesis. ${ }^{1}$ This hormone, present in the plasma of anemic animals, has not yet been isolated, but analysis of highly purified preparations suggests that it is a glycoprotein. ${ }^{2}$ It has been suggested ${ }^{3}$ that short periods of hypoxia initiate erythropoietin secretion which in turn stimulates erythropoiesis, and with frequent minute adjustments the equilibrium of the normal red cell mass is thus maintained within normal limits.

While erythropoietic activity has been demonstrated in 10-fold concentrated Borsook extract of normal human plasma by using the hypophysectomized rat assay, ${ }^{4}$ erythropoietin has not been found in raw plasma from humans. Critics of the theory that erythropoietin normally regulates red cell production argue that the hormone is absent from plasma of non-anemic animals and that it is elicited as a "panic mechanism" ${ }^{5}$ to compensate for blood loss. Proponents of the theory contend that, because only slight steady stimulation is required to sustain homeostasis, a small concentration of the hormone is present normally and that the starved rat assay is not sufficiently sensitive to detect it at this low level.

The enhanced sensitivity of the transfused plethoric mouse ${ }^{6}$ to small quantities of erythropoietin is uniform in our experience; as a consequence, such mice have supplanted the starved rat as assay animals in our laboratory. Moreover, the increased sensitivity resulting from suppression of erythropoiesis occurs without apparent injury to the bone marrow. ${ }^{7}$ Purification of erythropoietin from anemic sheep plasma ${ }^{2}$ and the definition of an erythropoietin "unit" have enabled us to relate dose to erythropoietic response. Consequently, we will describe the accelerated erythropoiesis engendered by injecting incremental doses of erythropoietin into transfused plethoric mice and measuring the response as demonstrated by the incorporation of radioiron $\left(\mathrm{Fe}^{59}\right)$ into circulating red cells. The results will be compared with those obtained using the more frequently employed starved rat method. 8

\section{MATERIALS AND METHODS}

Male Sprague-Dawley rats weighing 100-120 g were used in the starved rat assay. They were allowed water only for 32 hours prior to the first intravenous injection of erythropoietin and for the duration of the experiment. Erythropoietin was given once daily for 2 days and on the third day $1.0 \mu \mathrm{c}$ of $\mathrm{Fe}^{59}$ (citrate) was administered intravenously. Sixteen hours later, the radioactivity of $1.0 \mathrm{ml}$ of blood obtained by cardiac aspiration was measured and calculated as per cent incorporation of the injected dose. 8

${ }^{*}{ }^{*}$ This report is taken from a paper appearing in Proc. Soc. Exptl. Biol. \& Med., 110:48;-5/(May/962)

${ }^{\dagger}$ Department of Medicine, University of Chicago.

$\ddagger_{\text {John }}$ and Mary R. Markle Scholar in the Medical Sciences. 
Transfused plethoric CF No. 1 young adult female mice were prepared by two $1.0 \mathrm{ml}$ intraperitoneal infusions of an 80 per cent saline suspension of washed packed red blood cells on consecutive days. ${ }^{6}$ Six days after the last infusion, hematocrits were at least 70 per cent, and in animals untreated with erythropoietin, reticulocytes were absent from the peripheral blood and incorporation of $\mathrm{Fe}^{59}$ into red cells was less than 0.2 per cent of the injected dose. Subcutaneous injections of erythropoietin were made on the third and fourth days ( 2 injections of erythropoietin). Radioiron $\left(\mathrm{Fe}^{59}\right.$ ) was administered intravenously on the fifth day. Preliminary studies indicated that the blood volume of mice prepared for assay by this method was 7 per cent of body weight, and the radioactivity of the red cells, expressed as per cent of the tracer dose, could be determined on the eighth day using this information.

In a subsequent modification of the model, erythropoietin was given to mice in a single subcutaneous injection ( 1 injection) 6 days after the transfusions. Fifty-six hours later, $0.5 \mu \mathrm{c}$ of ferric $\left(\mathrm{Fe}^{59}\right)$ chloride was injected into the tail vein. Three days thereafter, the animals were sacrificed, and blood from the thoracic aorta was counted in a well scintillation counter.

Erythropuietin was purified by repeatedly passing plasma from sheep rendered anemic by phenylhydrazine injections, through DEAE (Diethylaminoethyl cellulose) and Amberlite IRC-50 resin. ${ }^{* 2}$ The preparation was dissolved and diluted to the desired strength with 0.9 per cent saline and then injected subcutaneously in $0.2 \mathrm{ml}$ volumes. One "unit" of erythropoietin causes the same degree of incorporation of $\mathrm{Fe}^{59}$ into the red blood cells of the starved rat as does $5 \mu \mathrm{M}$ of cobaltous ion. ${ }^{6}$

Hematocrits were determined with the micro-hematocrit method.

The starved rat assay distinguishes between injections of saline and 2 units of erythropoietin, but doses of less than 1 unit produce a response less than or equal to that provoked by saline (Fig. 1). The transfused plethoric mouse is sensitive to doses of 0.125 units of erythropoietin by the 2-injection technique of assay, but the 1-injection technique detects a distinct effect with 0.05 units of erythropoietin. When the volume of saline diluent is 5 times $(1.0 \mathrm{ml}$ instead of $0.2 \mathrm{ml}$ ) the usual amount, there is no appreciable change in the response (Table 1). Increasing the dose of erythropoietin above 6 to 8 units causes only a small increase in radioiron incorporation. Apparently, there is a sigmoidal relationship between $\mathrm{Fe}^{59}$ incorporation and the log-dose of erythropoietin.

\section{DISCUSSION}

It is evident that the transfused plethoric mouse is more sensitive to small increments of erythropoietin than the starved rat in which discrimination is possible with a minimum of about 1 unit in our hands. Although persistently variable results prevented us from distinguishing between doses of erythropoietin less than 1 unit and saline, Schleuter et al. ${ }^{9}$ described a sigmoidal curve of $\mathrm{Fe}^{59}$ incorporation and $\log$-dose of purified erythropoietin ranging from 0.6 units and 25 units in the starved rat. In Schleuter's laboratory standardization of erythropoietin is dependent upon slightly greater discrimination at lower doses than we can regularly obtain, although it is not clear from his data that less than 1 unit can be determined with precision.

Previously, the erythropoietic stimuli were given in 2 daily injections, and the 16-hour - .

\footnotetext{
*Prepared under USPHS Grant H-5393 to the University of Chicago by Armour and Com-
} pany Research Division on March 16, 1961. 
Table 1

RESULTS

RELATION OF INCREMENTAL DOSES OF ERYTHROPOIETIN AND THE INCORPORATION OF $\mathrm{Fe}^{59}$ INTO CIRCULATING RED CELLS

\begin{tabular}{|c|c|c|c|c|c|c|c|c|}
\hline \multicolumn{3}{|c|}{ 1. Starved rat (2 injections) } & \multicolumn{3}{|c|}{ 2. Transfused mouse ( 2 injections) } & \multicolumn{3}{|c|}{ 3. Transfused mouse ( 1 injection) } \\
\hline Dose (units) & $\begin{array}{l}\text { Per cent } \\
\mathrm{Fe}^{59} \text { inc. }\end{array}$ & $\begin{array}{l}\text { No. of } \\
\text { animals }\end{array}$ & Dose (units) & $\begin{array}{l}\text { Per cent } \\
\mathrm{Fe}^{59} \text { inc. }\end{array}$ & $\begin{array}{l}\text { No. of } \\
\text { animals }\end{array}$ & Dose (units) & $\begin{array}{l}\text { Percent } \\
\text { Fe } 59 \text { inc. }\end{array}$ & $\begin{array}{l}\text { No. of } \\
\text { animals }\end{array}$ \\
\hline 12 & $21.2 \pm 4.2^{*}$ & 5 & 12 & $24.1 \pm 4.2$ & 5 & 24 & $59.1 \pm 7.0$ & 8 \\
\hline 8 & $18.5 \pm 6.8$ & 5 & 8 & $20.5 \pm 3.5$ & 5 & 9 & $53.1 \pm 16.0$ & 8 \\
\hline 4 & $12.9 \pm 1.1$ & 5 & 4 & $18.6 \pm 3.4$ & 5 & 6 & $47.1 \pm 10.1$ & 8 \\
\hline 2 & $12.8 \pm 2.2$ & 5 & 2 & $17.8 \pm 4.8$ & 5 & 3 & $30.5 \pm 4.7$ & 8 \\
\hline 1 & $8.6 \pm 4.1$ & 5 & 1 & $11.3 \pm 2.9$ & 5 & 1 & $14.7 \pm 4.0$ & 8 \\
\hline 0.5 & $4.7 \pm 1.6$ & 5 & 0.5 & $7.2 \pm 4.7$ & 5 & 0.5 & $7.6 \pm 2.5$ & 7 \\
\hline 0.25 & $6.6 \pm 1.1$ & 5 & 0.25 & $3.7 \pm 1.5$ & 5 & 0.1 & $1.8 \pm 1.4$ & 7 \\
\hline \multirow[t]{4}{*}{ Saline } & $6.1 \pm 0.8$ & 5 & 0.125 & $1.2 \pm 0.5$ & 5 & 0.05 & $0.9 \pm 0.3$ & 8 \\
\hline & & & 0.0625 & $0.4 \pm 0.3$ & 5 & Saline & $0.2 \pm 0.0$ & 8 \\
\hline & & & 0.03125 & $0.3 \pm 0.2$ & 5 & 3 units $/ \mathrm{ml}$ & $26.8 \pm 6.9^{\dagger}$ & 7 \\
\hline & & & Saline & $0.2 \pm 0.1$ & 5 & $1 \mathrm{unit} / \mathrm{ml}$ & $15.3 \pm 4.8^{\dagger}$ & 7 \\
\hline
\end{tabular}

* 1 standard deviation.

$\dagger$ Administered in $1.0 \mathrm{ml}$ saline. 




Figure 1. Radioiron incorporation in the rat and mouse following administration of erythropoietin.

erythrocyte incorporation of a tracer dose of $\mathrm{Fe}_{59}$ was determined 24 hours after the second dose of erythropoietin. This pattern was employed initially when the plethoric rat was explored as a bioassay animal. ${ }^{10,11}$ The results of recent physiological studies ${ }^{6}$ suggested that using a single dose of erythropoietin and postponing the radioiron injection (into the mouse) to more than 24 hours later would yield greater differentiation of the erythropoietic effect. We therefore undertook a brief investigation to determine the optimal time of intravenous $\mathrm{Fe}^{59}$ administration after a single subcutaneous injection of erythropoietin. Maximum values occurred at 48 and 60 hours, followed by a rapid decrease in total incorporation of the radioiron.

We abandoned the transfused plethoric rat as an assay animal, because although reticulocytes and $\mathrm{Fe}^{59}$ incorporation diminished, ${ }^{10}$ the low base readily achieved in the plethoric mouse could never be obtained in the rat. Gastric bleeding associated with plethora in the rat is a further undesirable feature which may provide the stimulus for continuing erythropoiesis in longer experiments. 12

The relation between the log-dose of small amounts of erythropoietin and radioiron incorporation in the mouse has not been reported before. It is conceivable that the sigmoidal doseresponse curve would be considered linear if only 1- to 6-unit doses were employed. Perhaps the linear relationship observed by others using urine concentrates ${ }^{13}$ and anemic plasma extracts ${ }^{11,14}$ falls within that dose range.

Although a single dose of 6 units of erythropoietin yielded a maximum reticulocytosis in the plethoric mouse, ${ }^{6}$ our results suggest that increased erythropoiesis is produced by doses greater than 6 units. Larger groups of animals may be required to lend some degree of statis- 
tical significance to this assertion.

Proof of the concept that erythropoietin is the sole regulator of physiological erythropoie$\operatorname{sis}^{3}$ (and not merely a "panic mechanism" assay which will demonstrate its presence in normal plasma. The transfused plethoric mouse described here, is to our knowledge, the most sensitive assay animal available, and in our experience is 10 to 20 times more sensitive than the starved rat when one is testing serum with slight erythropoietic potency. This enhanced discrimination doubtlessly will aid in the demonstration of activity in human plasma in concentrations well below those detected using the starved rat. Currently, we are investigating the presence of erythropoietic factor in the plasma of normal and mildly anemic patients.

\section{LITERATURE CITED}

1. Carnot, P., and C. Deflandre. Compt. Rend. Acad. Sc., 143:384, 1906.

2. Goldwasser, E., and W. F. White. Fed. Proc., 18:236, 1959.

3. Jacobson, L. O., and E. Goldwasser. Brookhaven Symposia in Biology, 10:110, 1958.

4. Gurney, C. W., E. Goldwasser, and C. Pan. J. Lab. Clin. Med., 50:534, 1957.

5. Stohlman, F., Jr. Proc. Soc. Exptl. Biol. and Med., 107:885, 1961.

6. Filmanowicz, E., and C. W. Gurney. J. Lab. Clin. Med., 57:65, 1961.

7. Jacobson, L. O., E. Goldwasser, and C. W. Gurney. "Haemopoiesis," Ciba Symposium, London, 1960, p. 423.

8. Fried, W., L. F. Plzak, L. O. Jacobson, and E. Goldwasser. Proc. Soc. Exptl. Biol. and Med., $94: 237,1957$.

9. Schleuter, R. J., H. Norgello, and W. F. White. Proc. Soc. Exptl. Biol. and Med., 103:43, 1960.

10. 'Gurney, C. W., and C. Pan. Proc. Soc. Exptl. Biol. and Med., 98:789, 1958.

11. Reichlin, M., and W. J. Harrington. Blood, 16:1298, 1960.

12. Dahl, J. D., R. K. Blaisdell, and E. Beútler. Proc. Soc. Exptl. Biol. and Med., 101:622, 1959.

13. Hodgson, G., M. Perrata, D. Yudilevich, and I. Eskuche. Proc. Soc. Expt1. Biol. and Med., 99:137, 1958.

14. Gallagher, N. I., D. Q. Hagan, J. M. McCarthy, and R. D. Lange. Proc. Soc. Exptl. Biol. and Med., 106:127, 1961. 


\section{THE HYPOXIA-INDUCED ERYTHREMIC MOUSE, AN ERYTHROPOIETIN BIOASSAY ANIMAL}

By

R. L. DeGowin,$^{\dagger}$ D. Hofstra and C. W. Gurney

The transfusion of mice provides plethoric bioassay animals sensitive to small amounts of erythropoietin. ${ }^{1-3}$ It has been our experience, however, that one transfusion requires the exsanguination of approximately two donor mice, and many tedious hours are involved in the preparation of 50 assay animals. If the plethoric state could be induced more simply, a great saving of time and animals would be realized.

Observations of the reduced rate of erythropoiesis in mountain dwellers after their descent to sea level, ${ }^{4}$ and the experience of Wildy and Cotes ${ }^{5}$ using a decompression chamber encouraged us to investigate hypoxia-induced erythremic assay mice. We will describe the diminished erythropoiesis which follows the return of these mice from a hypoxic environment to air at ambient pressure and report their reaction to injected erythropoietin. These observations confirm and extend those of Wildy and Cotes, ${ }^{5}$ and indicate the ease with which an ideal system for the study of erythropoiesis may be prepared.

\section{MATERIALS AND METHODS}

Transfusion plethora was induced by giving CF No. 1 adult female mice two $1.0 \mathrm{ml}$ intraperitoneal injections of an 80 per cent suspension of packed red blood cells in physiological saline on consecutive days. Six days after the second transfusion, when the hematocrits were about 75 per cent, erythropoiesis had diminished ${ }^{1}$ and the animals were ready for use.

Hypoxia was produced in a steel chamber (modified from a design by Wildy and Cotes) by a vacuum pump which evacuated 1.7 cubic feet of air per minute (Fig. 1). A valve composed of a weighted nylon ball floating on the incoming air column maintained the intramural pressure at one-half atmosphere, simulating an altitude of about 18,000 feet. A gauge at the pump's inlet registered the system's pressure.

Eight-week-old CF No. 1 female mice weighing from 20 to $23 \mathrm{~g}$ were provided with water and a regular laboratory mouse diet while they were in the chamber. They were removed from the chamber for one hour each day for cage cleaning and blood counts. Although exposure to light is not known to alter the erythropoietic response to hypoxia, cages were rotated so that they received similar exposure to light. Some of the mice received $1.0 \mathrm{mg}$ to $3.5 \mathrm{mg}$ of irondextran (Imferon) subcutaneously and intramuscularly. Exposure to hypoxic conditions lasted from two to four weeks. Measurements of the hematocrit (microhematocrit method), hemoglobin (cyanmethemoglobin method), and reticulocytes (brilliant cresyl blue stain, counts of 1,000 cells) were performed on blood taken from the tail vein.

\footnotetext{
*This report is taken from a paper appearing in J. Lab. and Clin. Med., 60:846/, 1962 .

$\dagger$ Department of Medicine, University of Chicago.

$\ddagger$ John and Mary R. Markle Scholar in the Medical Sciences.
} 


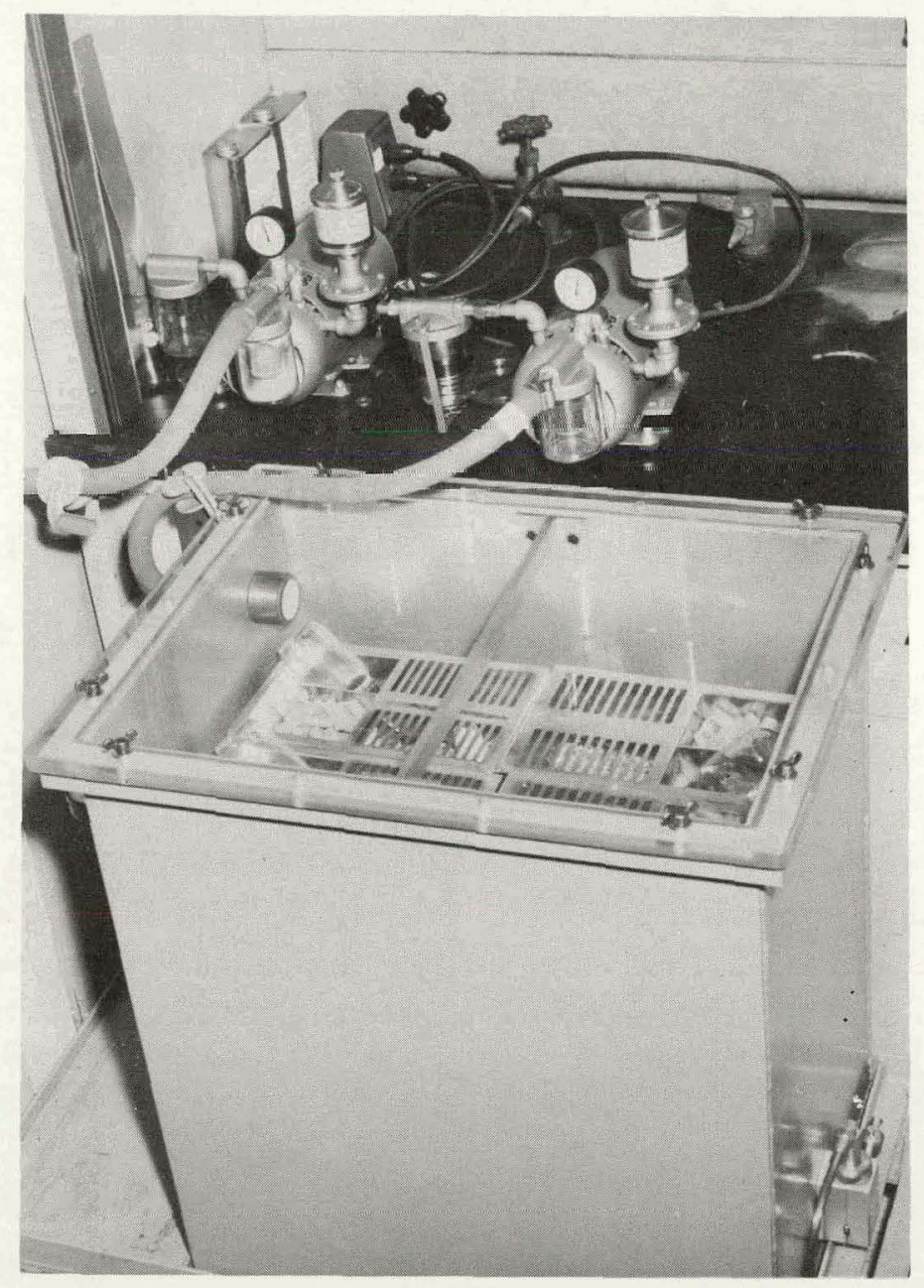

Figure 1. Decompression chamber: chamber is exhausted by single pump in upper center.

When the absence of reticulocytes in the peripheral blood of mice removed after several weeks in the hypoxia chamber indicated that erythropoiesis had ceased, the duration of the effect of hypoxia and the effect of exogenous erythropoietin were estimated simply with radioiron as follows:

After three weeks of hypoxia, four groups of mice were removed from the chamber. Group one received a radioiron tracer $\left(0.5 \mu \mathrm{c} \mathrm{Fe} \mathrm{Cl}_{3}\right)^{*}$ intravenously on the day of removal. Groups two and three received subcutaneous injections of 0.5 units of erythropoietin ${ }^{\dagger}$ and of normal saline respectively on the fifth day post-hypoxia, and both of these groups received the radioiron tracer 56 hours (seventh day post-hypoxia) after their injections. Group four received radioiron alone on the tenth day post-hypoxia. Erythrocyte radioactivity was determined as the per cent

\footnotetext{
* The specific activity of the radioiron tracer was $36 \mathrm{mc} / \mathrm{mg}$ Fe so that with the administration of $0.5 \mu \mathrm{c}$ of $\mathrm{Fe}^{59}$ each mouse receives $1 / 72 \mu \mathrm{g} \mathrm{Fe}$.

${ }^{\dagger}$ Prepared by Armour and Company Research Division under AEC Subcontract \#21 under Contract \#18 AT-(11-1)-69 with the University of Chicago.
} 
Table 1

THE HYPOXIA-INDUCED PLETHORIC MOUSE:RESPONSE TO ERYTHROPOIETIN

\begin{tabular}{|c|c|c|c|c|c|}
\hline & \multicolumn{4}{|c|}{ Incorporation of $\mathrm{Fe}^{59}$ (per cent \pm S.D.) } \\
\hline & & $\begin{array}{l}\text { No } \\
\text { erythropoietin }\end{array}$ & $\underset{\text { (per group) }}{\text { Animals }}$ & $\begin{array}{l}0.5 \text { units } \\
\text { erythropoietin }\end{array}$ & $\underset{\text { (per group) }}{\text { Animals }}$ \\
\hline & Days post-hypoxia ${ }^{*}$ & & & & \\
\hline Group 1 & $\begin{array}{l}0 \\
7\end{array}$ & $69.2 \pm 4.9$ & (9) & $122^{-}+35$ & - \\
\hline Group III & 7 & $0.2 \pm 0.0$ & (7) & - & - \\
\hline \multirow[t]{3}{*}{ Group IV } & 10 & $0.2 \pm 0.1$ & (7) & - & - \\
\hline & Days post-transfusion & & & & \\
\hline & 8 & $0.2 \pm 0.0$ & (7) & $7.0 \pm 2.8$ & (8) \\
\hline
\end{tabular}

* Day on which radioiron was administered.

of the injected $\mathrm{Fe}^{59}$ in all groups three days after the injection of $\mathrm{Fe}^{59}$, by counting a measured volume of blood in a scintillation well counter, using a blood volume of 7 per cent of the animal's body weight, and comparing the calculated total radioiron activity of the blood with a standard prepared from an aliquot of the radioiron at the time of injection. Preliminary experiments employing $\mathrm{Fe}^{59}$-labeled erythrocytes demonstrated that the blood volumes of the plethoric mice were approximately 7 per cent of the body weight. The intravenous radioiron was given 56 hours after the erythropoietin injections.

\section{RESULTS}

In animals which received $2 \mathrm{mg}$ of iron dextran (Imferon) intramuscularly before decompression, the average increase in hemoglobin was $1.9 \mathrm{~g}$ per cent greater after 2 weeks of hypoxia than was the increase in non-iron-treated animals. The average hematocrit of iron-treated animals exceeded that of the non-iron-treated group by 6 per cent (Fig. 2). Other experiments demonstrated that increasing the dose of iron dextran above a minimum of $1 \mathrm{mg}$ intramuscularly did not increase the final hematocrits significantly. A slightly greater mean hematocrit (average 76 per cent) was produced when the duration of hypoxia was increased to four weeks.

When iron-treated mice were removed from the chamber after two weeks' hypoxia, the initial mean hematocrit and hemoglobin declined during the ensuing ten days from 75 per cent and $20.6 \mathrm{~g}$ per cent to 63 per cent and $17.5 \mathrm{~g}$ per cent (Fig. 3). Reticulocyte counts fell from 2.6 per cent at the time of removal from the chamber to zero in six days and only an occasional reticulocyte was seen on daily films until after the tenth day.

When hypoxia was maintained for three weeks, the period during which the peripheral blood was essentially reticulocyte-free was extended to the 14th day. Erythrocyte incorporation of radioiron $\left(\mathrm{Fe}^{59}\right.$ ) remained at about 0.3 per cent from the seventh through the 14th day (Table 2).

Prolonging exposure to one-half atmosphere from three weeks to four weeks did not increase the duration of erythremia after the mice were returned to ambient pressure. After the first week post-hypoxia, during which the fall in hematocrit is retarded, the shape of the curve 


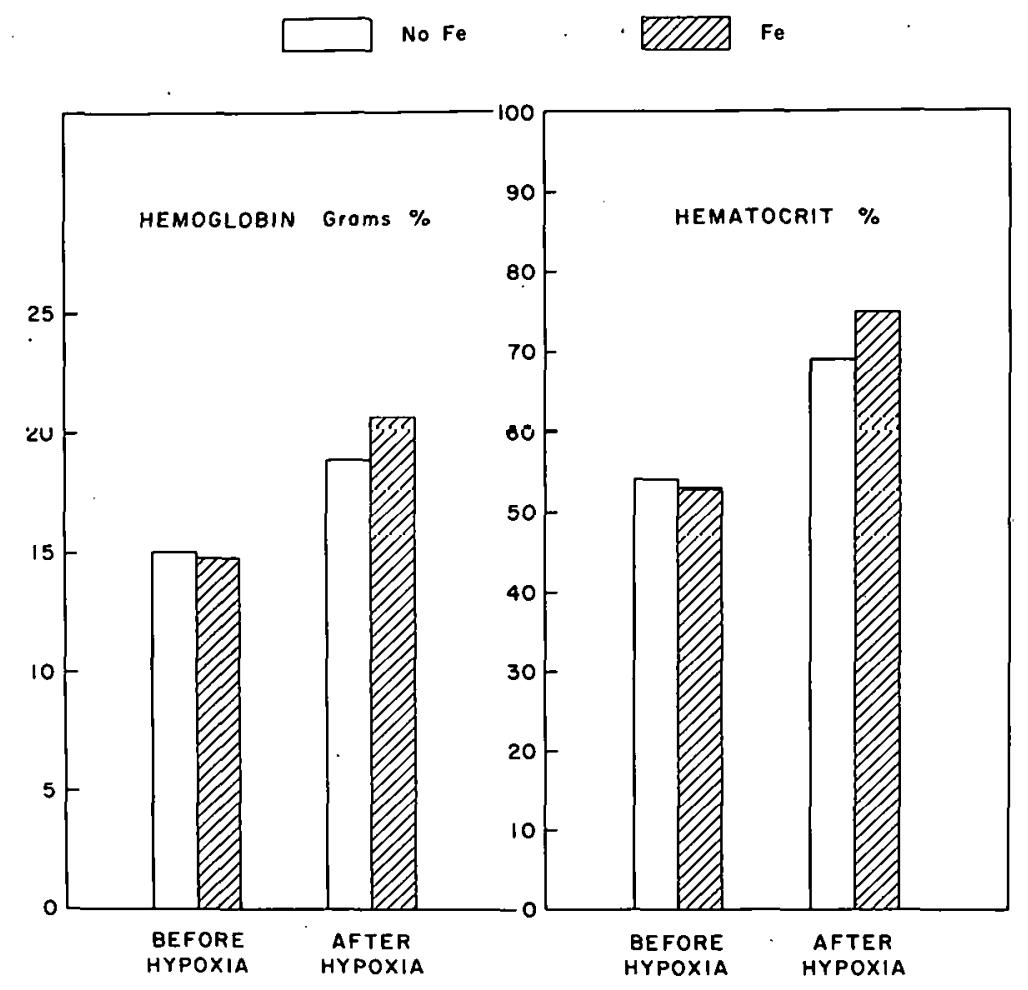

Figure 2. The effect of iron-dextran on hypoxiainduced erythremia.

representing the decline of the hematocrit in mice made plethoric by exposure to a hypoxic environment (Fig. 4), is similar to that produced by repeated erythropoietin injection or by transfusion. ${ }^{6}$

When radioiron was administered on the first day after three weeks of hypoxia, the 72hour $\mathrm{Fe}^{59}$ incorporation into circulating red cells was 69.2 per cent (Table 1). Animals receiving radioiron on the seventh post-hypoxia day demonstrated an incorporation identical with that low level ( 0.2 per cent) attained in the transfused plethoric mouse, ${ }^{2}$ and the 72 -hour incorporation in a group of chamber-mates given radioiron on the tenth post-hypoxia day was still only 0.2 per cent. When 0.5 units of erythropoietin was given on the fifth post-hypoxia day radioiron incorporation in hypoxigenic plethoric mice was 12.2 per cent as compared to 7.0 per cent in transfused plethoric mice. ${ }^{2}$ (Table 1.)

\section{DISCUSSION}

Controversy concerning the role of erythropoietin in the proposed cybernetic scheme regulating normal red cell production ${ }^{7}$ may largely be fostered by an inability to detect small quantities of the hormone with gross techniques. For example, the starved rat may incorporate three to five per cent of a radioiron tracer into its circulating red cells after receiving saline injections. ${ }^{8}$ In our experience, statistically significant increases in radioiron incorporation in this animal cannot regularly be obtained with less than 1 unit of erythropoietin.

Transfused plethoric mice however, consistently demonstrate a low baseline radioiron incorporation of 0.2 per cent, and reticulocyte-free peripheral blood after saline injection, and 


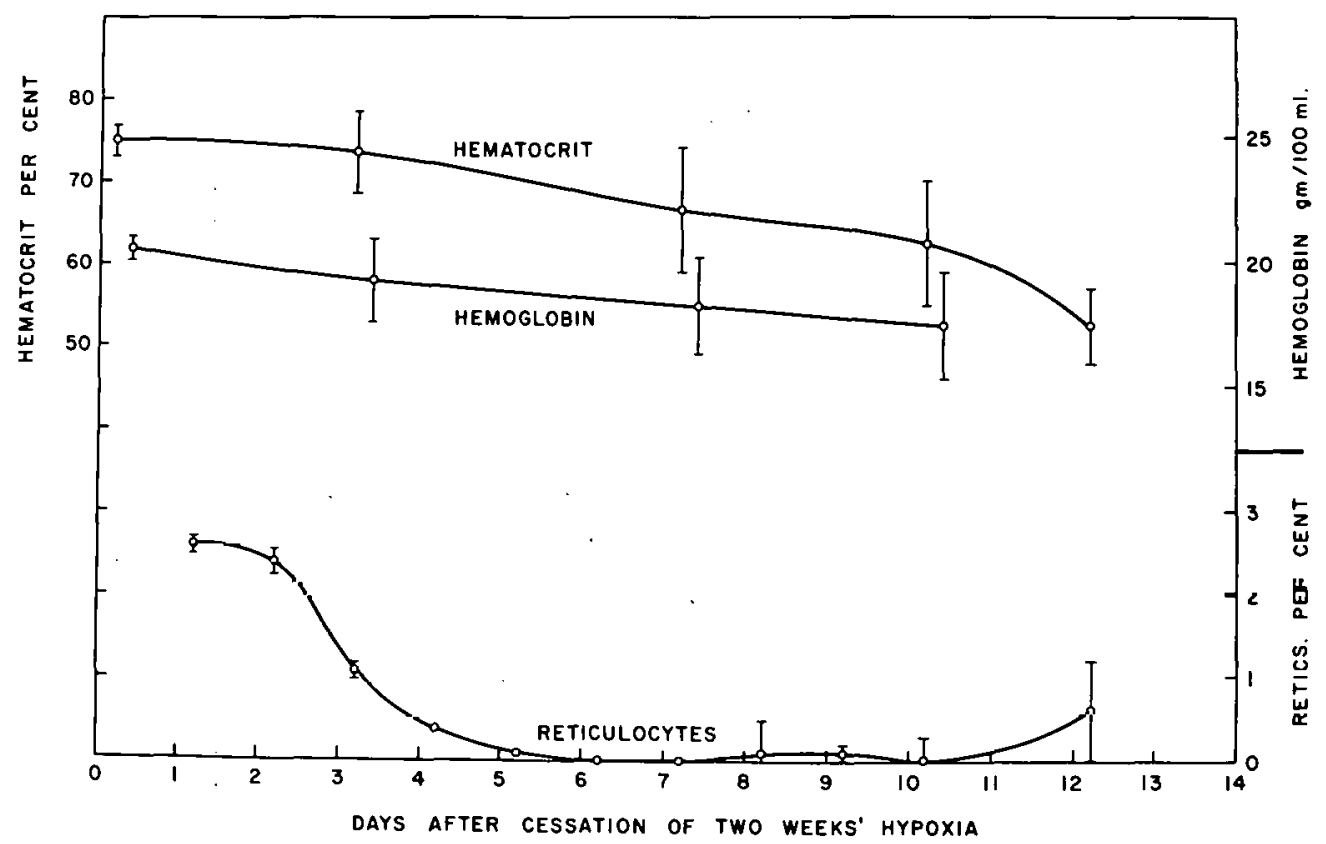

Figure 3. The decline of hematocrit, hemoglobin and reticulocytes after cessation of two weeks' hypoxia $(18,000 \mathrm{ft}$.).

Table 2

SUPPRESSION OF RETICULOCYTOSIS AND ERYTHROCYTE Fe INCORPORATION IN MICE AFTER CESSATION OF THREE WEEKS OF HYPOXIA

\begin{tabular}{c|c|c|c}
\hline Days post-hypoxia & $\begin{array}{c}\text { Reticulocyte count } \\
\text { (per cent } \pm \text { S.D.) }\end{array}$ & $\begin{array}{c}\text { Animals } \\
\text { (per group) }\end{array}$ & $\begin{array}{c}\text { Erythrocyte Fe } \\
\text { incorporation } \\
\text { (per cent } \pm \text { S.D.) }\end{array}$ \\
\hline 9 & $<0.1$ & $(8)$ & $0.31 \pm 0.1$ \\
11 & $<0.1$ & $(8)$ & $0.34 \pm 0.1$ \\
12 & $<0.1$ & $(7)$ & $0.31 \pm 0.1$ \\
15 & $<0.1 \ldots$ & $(6)$ & $0.29 \pm 0.1$ \\
\hline
\end{tabular}

Day on which radioiron was administered.

we have previously demonstrated the superiority of the plethoric mouse for bioassay of erythropoietin. 2,3

The time, cost and inconvenience of bleeding $80^{\circ}-100$ donor mice, washing and packing their red cells, transfusing recipient mice on the same day, and repeating the whole procedure the next day in order to obtain 50 assay animals has probably discouraged widespread acceptance of the plethoric mouse bioassay. The use of hypoxia to produce plethora dispenses with these difficulties. Sufficient numbers of mice can be maintained in a chamber and removed at the required intervals after the preliminary 3 -week period necessary for the production of hypoxia. The number of plethoric mice prepared in decompression chambers is limited only by 


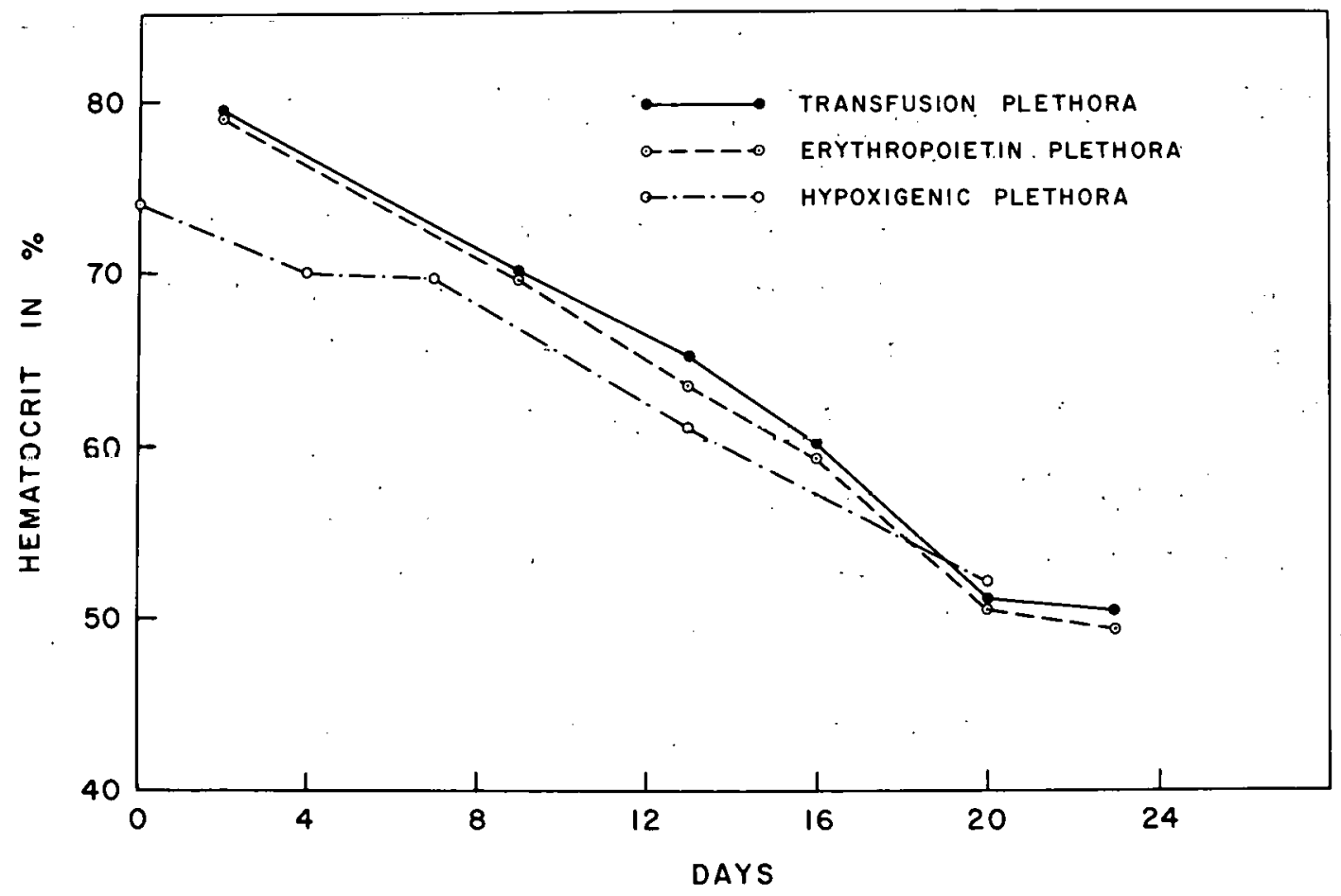

Figure 4. Decline in hematocrit in plethoric mice.

the number of chambers in operation, since only a few minutes daily is required to service a chamber.

Mice receiving parenteral iron before decompression attain average final hematocrits six per cent greater than those not so treated, therefore, we regularly give a minimum dose of 1.0 $\mathrm{mg}$ of Imferon intramuscularly to provide ample iron storage prior to the expected period of vigorous erythropoiesis. No mice have died in the hypoxia chamber under conditions described, although the animals are sluggish during the first few days, drink less, and initially lose one to two $g$ of body weight. However, they promptly regain their vigor and eat and drink voraciously if returned to ambient air, and they gradually resume normal behavior within the chamber after several days. A period of three weeks provides sufficient time for adjustment to a hypoxic environment: periods of longer than three weeks are unnecessary. It is suggested that a new state of equilibrium is being approached at this time, and more striking degrees of plethora might most efficiently be obtained by increasing the degree of hypoxia after 2 or 3 weeks.

We have found the following schedule to be optimal:

1. Removal from chamber after three weeks' hypoxia.

2. Maintenance at ambient pressure for five days.

3. Injection of test material on fifth day post-hypoxia at ambient pressure.

4. Administration of $\mathrm{Fe}^{59}$ tracer about 60 hours later.

5. Determination of erythrocyte incorporation of $\mathrm{Fe}^{59}$ on the tenth day at ambient pressure. Upon termination of the assay, the hematocrit of each animal's blood is determined. Results are valid only if hematocrits exceed 55 per cent, thereby excluding resumption of endogenously-stimulated erythropoiesis as a cause for a false positive result. 9 


\section{LITERATURE CITED}

1. Jacobson, L. O., E. Goldwasser, and C. W. Gurney. In Wolstenholme, G. E. W. and O'Connor, M., editors: Ciba Foundation Symposium on Haemopoiesis, London, 1960, J. and A. Churchill Ltd., Publishers, pp. 423-45.

2. DeGowin, R. L., D. Hofstra, and C. W. Gurney. Fed. Proc., 21:71, 1962.

3. DeGowin, R. L., D. Hof stra, and C. W. Gurney. Proc. Soc. Exptl. Biol. Med., 110:48, 1962.

4. Reynafarje, C., R. Lozano, and J. Valevieso. Blood, 14:433, 1959.

5. Wildy, J., and P. M. Cotes. Biochim. J., 82:6P, 1962.

6. Gurney, C. W., R. DeGowin, D. Hofstra, and J. Byron. In Jacobson, L. O. and Doyle, M:, editors: Erythropoiesis, New York, Grune and Stratton, Publishers, 1962, p. 151.

7. Stohlman, F., Jr. Proc. Soc. Exptl. Biol. Med., 107:885, 1961

8. Fried, W., L. F. Plzak, L. O. Jacobson, and E. Goldwasser. Proc. Suc. Exptl. Biol. Med., $94: 237,1957$.

9. Gurney, C. W., N. Wackman, and E. Filamanowicz. Blood, 17:531, 1961. 




Current concepts hold that blood production can be traced to one or several lines of primitive cells of the reticuloendothelium. While it appears reasonable to conclude that differentiation of the furmed elements of the blood can clearly be followed back as far as early differentiated cells, the conflicting opinions and concepts regarding hemopoiesis prior to the emergence of these early forms suggest that a hard core of factual information pertaining to the earliest stages of cellular differentiation and maturation is lacking. This is particularly unfortunate, since many of the most common and serious hematological disorders appear to be related to abnormalities of cellular production, differentiation, and maturation in precisely these early phases. Polycythemia vera, aplastic pancytopenias, myelofibrosis, and the leukemias may all be related to primary pathological processes afflicting the formed elements of the bone marrow before maturation has brought the cells to a stage where they can be recognized as primitive but already committed precursors. It is therefore of great practical as well as theoretical interest that a better understanding of the earliest phases of reticuloendothelial proliferation and differentiation be obtained.

Until recently, the most rewarding studies have been primarily morphological. These techniques, however, have serious limitations, and a series of experiments undertaken in our laboratory places primary emphasis on function rather than morphology. Our interest in the behaviour of stem cells arose when investigations into the nature of erythropoiesis led to the preparation of highly purified samples of erythropoietin, ${ }^{1}$ and our studies of erythropoiesis in the hypertransfused mouse led to the conclusion that erythropoietin acts by inducing differentiation of undifferentiated cells of the reticuloendothelium. ${ }^{2}$ We believe that erythropoietin acts upon a population of undifferentiated cells which we shall refer to as stem cells. This conclusion has also been reached independently by Alpen and Cranmore ${ }^{3}$ and $\operatorname{Erslev}^{4}$ who employed quite different methods of investigation.

A single injection of sheep erythropoietin will induce in the hypertransfused mouse, a burst of erythropoietic differentiation which ultimately culminates in a reticulocyte response in the peripheral blood. ${ }^{2}$ Not only are reticuloctyes absent from the blood prior to injection of erythropoietin in these animals, but incorporation into erythrocytes of radioactive iron is reduced almost to zero, and morphological studies show virtually no erythropoietic activity. Following a single injection of erythropoietin, a wave of erythropoiesis in the hematopoietic organ cells precedes the reticulocytosis observed in the peripheral blood.

These observations afforded us the information necessary to devise a system for the study of the "stem cell compartment." Since a given amount of erythropoietin will produce an erythropoietic response which can be quantitated, and since this response begins by the triggering of

* This paper was presented at the IX Congress of the International Society of Hematology, in Mexico City, September, 1962 and will appear in the Proceedings of the Congress.

${ }^{\dagger}$ John and Mary R. Markle Scholar in the Medical Sciences. 
undifferentiated cells, or stem cells, the response to a standard dose of erythropoietin may be considered to reflect the sensitivity or integrity of the stem cell compartment at the time of injection. We have therefore devised an "erythropoietin tolerance test" for the study of stem cells. The test animal is the polycythemic mouse, prepared by transfusion. ${ }^{5}$ Various stimuli, either separately or in combination, are applied to the "stem cell compartment" and the effect is measured in terms of reduction of the anticipated response to a standard dose of erythropoietin. Using this erythropoietin tolerance test, recovery of the stem cell compartment from injury as well as initial measurement of the injury, may be investigated.

\section{EXPERIMENTAL}

Large numbers of normal mice are transfused to hematocrits of about 75 per cent to eliminate erythropoiesis (Fig. 1). Six units of erythropoietin per animal will produce a predictable erythropoietic response which may be measured either by reticulocytosis, or as was determined here, by the per cent of a tracer dose of radioiron given 24 hours after the erythropoietin which is incorporated into newly formed red cells over the subsequent 72 hours. This value is 27 per cent. If however, immediately prior to erythropoietin, radiation is administered in



Figure 1. Impaired response to erythropoietin in the irradiated polycythemic mouse. 
the dose indicated, impairment of the response of stem cells to the erythropoietic challenge is observed. The two points of interest are first) the similarity of slope of radiation damage observed here, with the slope of the radiation damage curve in a number of other biological systems such as those of Puck and Marcus, ${ }^{6}$ Hewitt and Wilson, ${ }^{7}$ and Elkind and Sutton, ${ }^{8}$ and second) although the L.D. 50 at 30 days for this strain of mouse is well above $600 \mathrm{r}$, about 95 per cent of the stem cells, as measured by this test, are damaged with as little as $300 \mathrm{r}$.

Figure 2 shows the impairment of response to erythropoietin following injection of actinomycin D. Incorporation of a tracer dose of radioiron administered after the erythropoietin is .

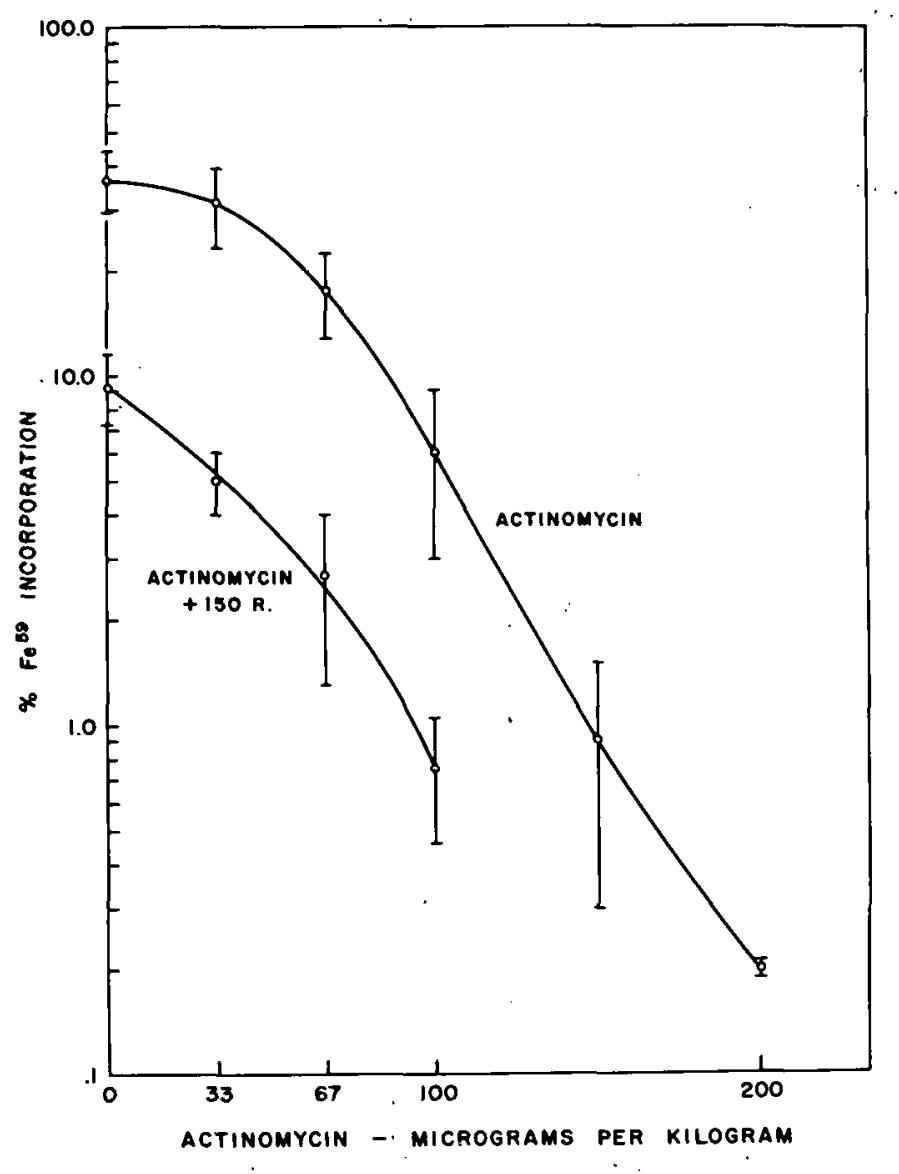

Figure 2. Impairment of stem cell response to erythropoietin by actinomycin or. actinomycin + $150 \mathrm{r}$ irradiation in the polycythemic mouse.

again used to determine the response to a given dose of erythropoietin. Results are plotted as average values plus or minus one standard deviation, and at least 7 animals are present in each group. Polycythemic animals incorporate 36 per cent of the tracer dose of radioiron administered 50 hours after the erythropoietin. Little stem cell damage is associated with extremely small doses of actinomycin, but after an initial plateau, a linear relationship exists between the dose of actinomycin and the log of the response, expressed as the per cent of the tracer dose of radioiron incorporated by newly formed red cells. A single dose of 200 micrograms per kilo- 
gram mouse body weight is sufficient to obliterate the stem cell responsiveness to erythropoietin. It is of interest to note that the shape of this curve resembles that seen for radiation damage to a number of biological systems, including the one employed here. The degree to which a fixed dose of 150 roentgens is additive to actinomycin damage upon stem cells is also demonstrated in this figure.

Figure 3 demonstrates yet another form of damage to the stem cell compartment. Colchicine, by virtue of its ability to arrest mitosis, is of great value in the study of cellular proliferation and differentiation, and it was for this reason that we explored the damaging effects of

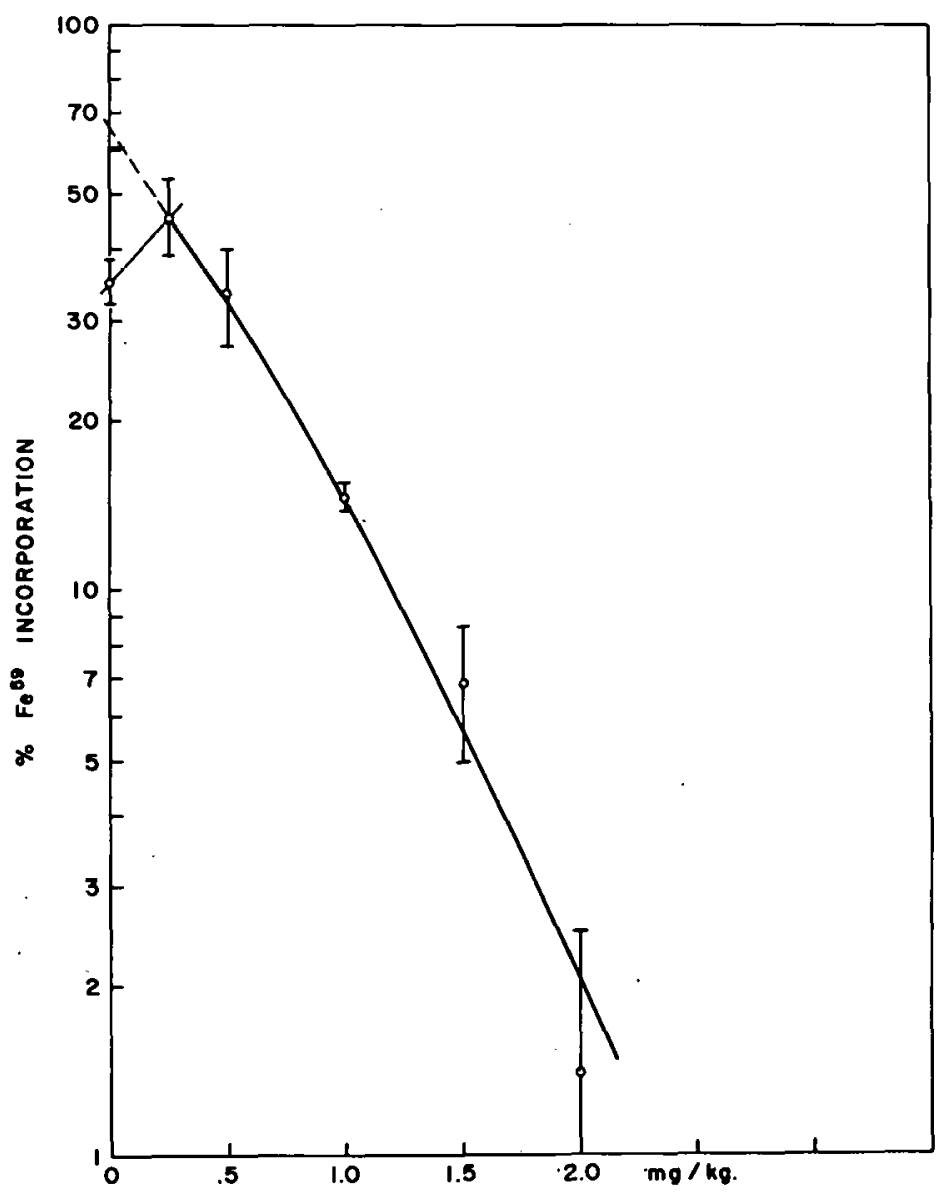

Figure 3. Impairment of stem cell response to erythropoietin by colchicine in the polycythemic mouse.

colchicine upon the stem cell compartment. It will again be noticed that there is a relationship between the dose of colchicine and the degree of impairment of the stem cell responsiveness to a standard dose of erythropoietin, and that the shape of this curve is similar to that obtained with irradiation or actinomycin. However, extremely small doses of colchicine demonstrate more than a plateau, and the response of the stem cell compartment, as measured in this system is actually increased when colchicine at the rate of .25 milligrams per kilogram of body weight is administered prior to injection of erythropoietin. 
We have repeatedly warned against the use of radioiron uptake as the sole measurement of erythropoietic response, and we believe it is essential that other functions of erythropoietic response be assessed periodically. Figure 4 shows the impairment of reticulocyte response to erythropoietin as a consequence of colchicine administration. Of interest are the overall decrease in area under the curve as a manifestation of total colchicine dosage, and the progres-

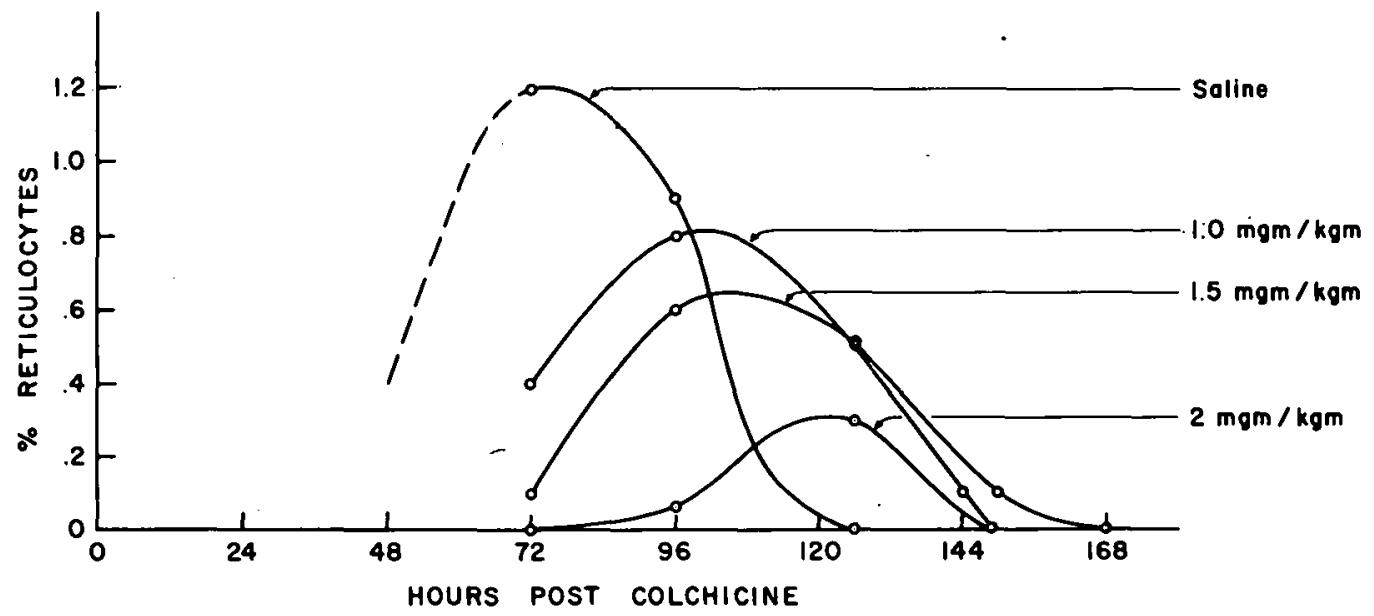

Figure 4. Reduction of reticulocyte response to erythropoietin in response to intravenous administration of colchicine.

sive delay in time of peak reticulocytosis occurring as the doses are increased. We believe that large doses of colchicine damage most of the stem cells so that they cannot respond to erythropoietin, but that mitosis is delayed without irreversible damage in a small number of stem cells and this lag is reflected in a delayed appearance of reticulocytes in the peripheral blood.

The recovery of responsiveness of the stem cell compartment to erythropoietin can also be determined by the erythropoietin tolerance test, and thus some insights may be gained regarding behaviour of the stem cell compartment. If large numbers of hypertransfused animals are subjected to the same degree of damage and different animals are given a stimulating dose of erythropoietin at different times after the insult, a pattern of recovery may be observed. Figure 5 shows such a pattern of recovery following 150 roentgens of radiation. When erythropoietin is given immediately after irradiation, the response as measured by radioiron incorporation is reduced to approximately 11 per cent. When, however, erythropoietin administration is delayed until 24 hours after irradiation, the incorporation of radioiron is even further reduced. There is in fact little evidence of recovery of the stem cell compartment from 150 roentgens of radiation for up to 6 days, but when administration of erythropoietin is delayed until the seventh day, a perfectly normal erythropoietic response ís obtained.

Different patterns of recovery are obtained when chemical agents are used to produce damage of the stem cell compartment. Figure 6 shows the pattern of recovery following actinomycin at a dose of 87 micrograms per kilogram of body weight. Although complete recovery of the stem cell compartment appears to have been achieved 96 hours after the administration of actinomycin, the magnitude of response is depressed a second time and impaired ability of the stem cell compartment to respond to erythropoietin is clearly evident 6 days following injury. 


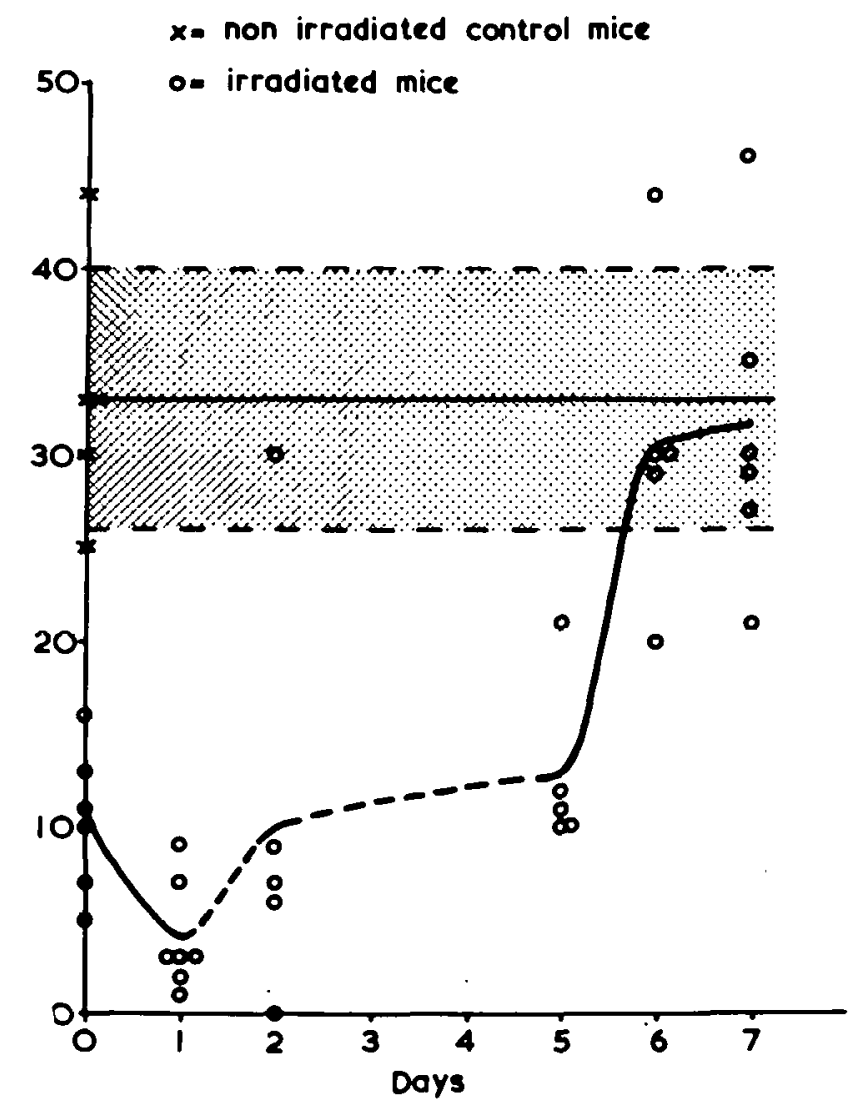

Figure 5. Stem cell recovery after 150 roentgens. Response related to time after irradiation at which erythropoietin is given.

A similar pattern is.observed with colchicine, as seen in Figure 7, and it would therefore appear that the pattern of recovery of stem cells following irradiation differs from the pattern of recovery which follows chemical change.

\section{DISCUSSION}

Time does not allow for a detailed consideration of the interpretation of these findings. It must be realized that the functional studies employing the erythropoietin tolerance test give a picture only of the number of stem cells in a receptive phase to the stimulus for differentiation into the red cell series at the time erythropoietin is given. This distinction must clearly be borne in mind.

The reconsitution of the stem cell compartment presents a problem of great interest and the fact that the adverse effect of irradiation of the stem cell compartment in the hypertransfused mouse will, after a period of time, disappear completely in the absence of erythropoiesis constitutes evidence for the multi-potential nature of the stem cell, for by analogy with at least one other. system, ${ }^{9}$ it is anticipated that radiation damage to a dormant population would be "stored" into the system and would be.demonstrable even after a protracted period of dor mancy. 


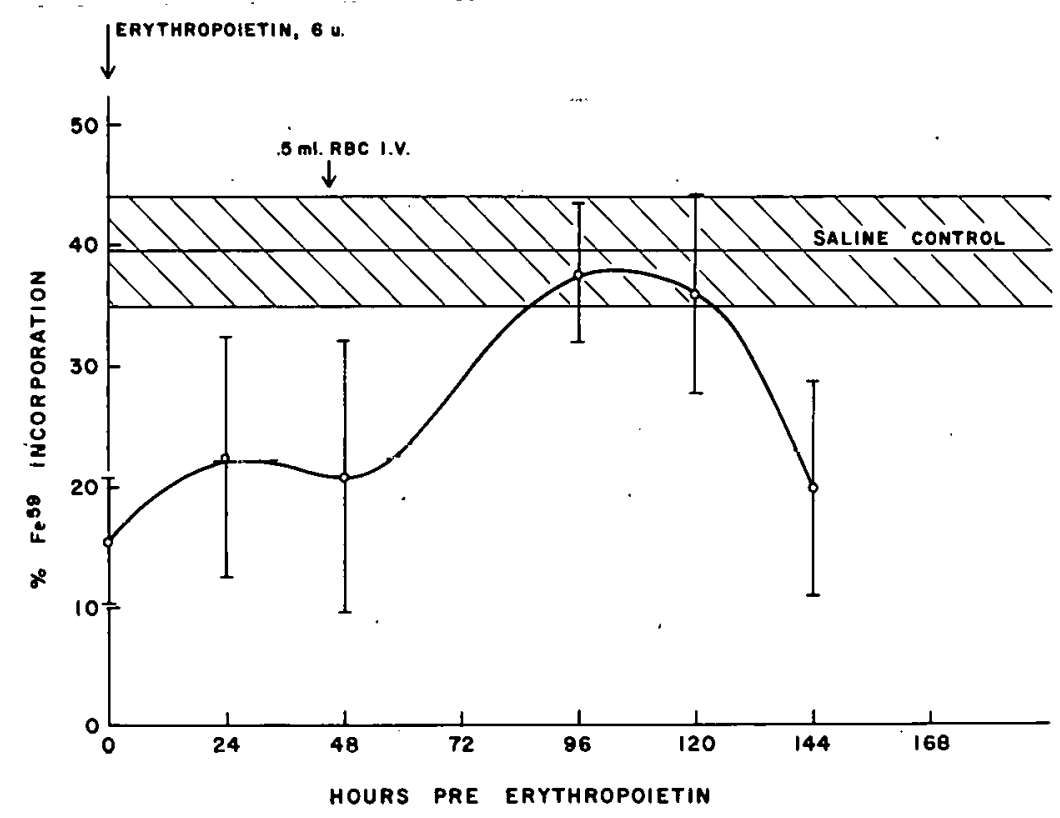

Figure 6. Stem cell response to erythropoietin following actinomycin D $87 \mu \mathrm{g} / \mathrm{kg}$ intravenously.

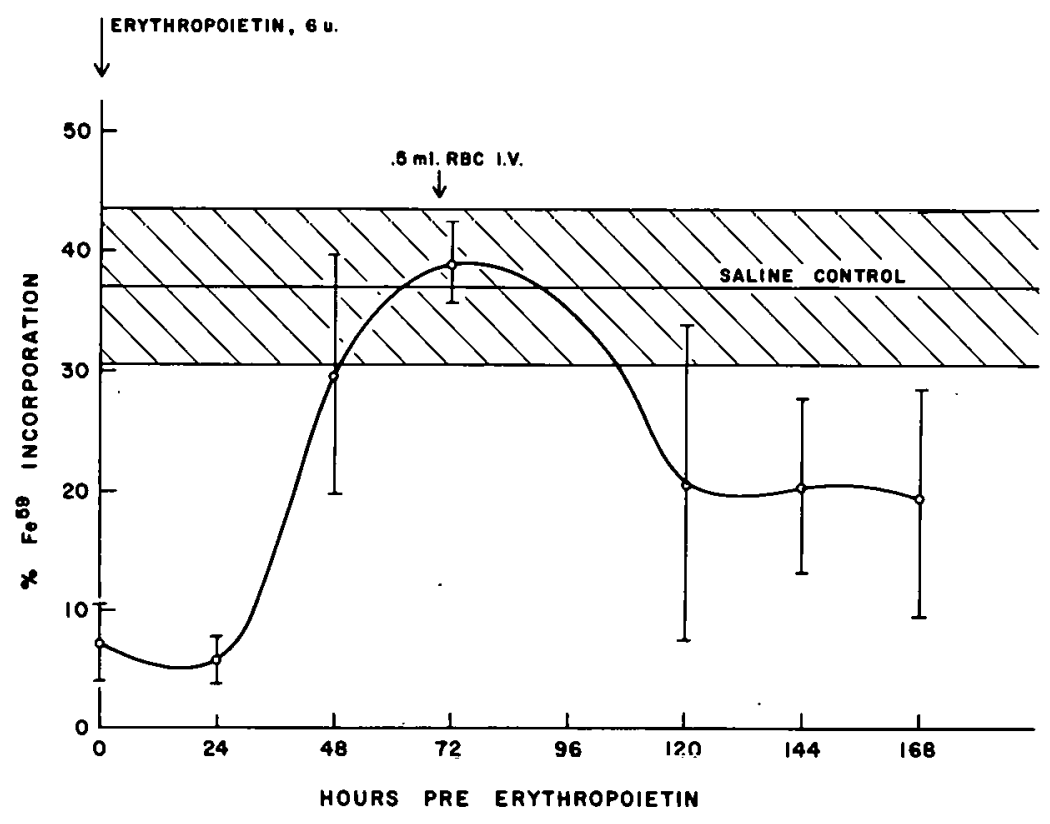

Figure 7. Stem cell response to erythropoietin following colchicine $1.125 \mathrm{mg} / \mathrm{kg}$ intravenously.

Some advantages offered by this model are:

1) Stem cells may be investigated in vivo and in situ.

2) Quantitative expressions of damage may be obtained. This is true only for damage less than that required to produce lethality. Although it is unfortunate that discrimination is lost in 
this system long before lethal levels of injury are reached, a great advantage is obtained in being able to quantitate low dose damage immediately or at any time after injury rather than having to wait 15 or 30 days to express per cent lethality.

3) Various chemotherapeutic, other poisonous chemical, and radiation doses may be equated one with another. Synergisms and antagonisms may thereby be sought.

4) Patterns of recovery of stem cells following damage give some insights into the k.inetics of the stem cell pool.

Although the data presented are open to a variety of interpretations, it is anticipated that additional functional, morphologic, and ultimately blochemical sludies of cellular differentiation and proliferation, employing the erythropoietin tolerance test or a modification thereof, will further our understanding of the properties of the stem cell pool.

\section{LITERATURE CI'IED}

1. White, W. F., C. W. Gurney, E. Goldwasser, and L. O. Jacobson. Recent Progress in Hormone Research, 16:219, 1960. Pincus, Ed. New York, Academic Press, Inc.

2. Filmanowicz, E., and C. W. Gurney. J. Lab. Clin. Med., 57:65, 1961.

3. Alpen, E. L., and D. Cranmore. In The Kinetics of Cellular Proliferation. F. S. Stohlman, Jr. Ed. New York, Grune and Stratton, Inc., 1959, pp. 290-300.

4. Erslev, A. J. Blood, 14:386, 1959.

5. DeGowin, R. L., D. Hofstra, and C. W. Gurney. Proc. Soc. Exptl. Biol. and Med., 110:48, 1962 .

6. Puck, T. T., and P. T. Marcus. J. Exptl. Med., 103:653, 1956.

7. Hewitt, H. B., and C. W. Wilson. Brit. J. Can., 13:69, 1959.

8. Elkind, M. M., and H. Sutton. Nature, 184:1293, 1959.

9. Crooks, J., W. R. Greg., A. G. Macgregor, and J. A. R. McIntósh. Second International Congress of Radiation Research, p. 28, 1962 (Abstract). 


\title{
INFLUENCE_OF SEVERAL HORMONES ON ERYTHROPOIESIS_AND_OXYGEN CONSUMPAION-IN THE HYPOPHYSECTOMIZED RAT ${ }^{*}$
}

\author{
By \\ J. W. Fisher ${ }^{\dagger}$ and J. J. Crook $^{\dagger}$
}

Although some recent evidence indicates that the kidney is the primary site of formation of erythropoietin, ${ }^{1-4}$ there is good evidence for the existence of extra-renal erythropoietic factors. ${ }^{5-7}$ We have postulated from our previous work that the partial response of the bilaterally nephrectomized animal to erythropoietic stimuli such as hypoxia may be due to the discharge of several hormones which alone or in combination produce an erythropoietic effect. ${ }^{3}$ In the present study, we have tested this postulate by determining the erythropoietic effects of several hormonal substances, some of which are known to be released during hypoxia. The hypophysectomized rat was selected as the test animal because of its known sensitivity to hormonal treatment. In an attempt to relate the ratio of tissue metabolic oxygen demand and supply with erythropoiesis, the influence of these compounds on oxygen consumption was also determined.

The hormonal substances studied were adrenocorticotrophic hormone, growth hormone, thyroid stimulating hormone, 3,5,3'-triiodothyronine, angiotensin, adrenocortical extract, corticosterone, 11-dehydrocorticosterone, 17- $\mathrm{OH}$ corticosterone, aldosterone and testosterone.

\section{MATERIALS AND METHODS}

Male rats of the Sprague Dawley strain were used in all studies, usually 10 in each assay. The procedure of Fried and co-workers ${ }^{8}$ was followed for the radioactive iron incorporation in RBC studies. Six week old animals were hypophysectomized by a standard technic ${ }^{\ddagger} 2$ to 3 weeks before assay. The hypophysectomized rats used in the adrenalectomy experiments were lightly anesthetized with ether and the adrenals removed through bilateral lumbar incisions. The animals were adrenalectomized three days prior to use and were maintained throughout on 0.9 per cent sodium chloride as drinking fluid. They were fed a diet consisting of milk, fresh vegetables and Rockland mouse diet ad libitum. The total dose of all test substances was injected subcutaneously (except for angiotensin which was injected intravenously) in 2 daily injections. On the third day $1 \mathrm{ml}$ of saline containing 1 microcurie of $\mathrm{Fe}^{59}$ citrate was given intravenously to each rat and standards were set up for later counting. Sixteen hours later, one $\mathrm{ml}$ of blood was obtained by cardiac aspiration, and the $\mathrm{Fe}^{59}$ incorporation into red cells was calculated accurding to the formula:

$$
\mathrm{Fe}^{59} \text { uptake }=\frac{\text { net counts per ml blood } \mathrm{x} 0.05 \text { body weight }}{\text { net counts injected }}
$$

\footnotetext{
* This report is taken from a paper appearing in Blood, 19:557, 1962. Part of the work was done while a guest investigator at the Argonne Cancer Research Hospital. Investigation supported by USPHS Grant A-2973 (C1) and USPHS Grant GM-K3-5990-C1 from the Institute of Arthritis and Metabolic Diseases.

- †Present address: Department of Pharmacology, University of Tennessee Medical Units, Memphis, Tennessee.

† Obtained from Hormones Assay Laboratories, Chicago, Illinois.
} 
The blood volume was assumed to be 5 per cent of the body weight. ${ }^{2}$ Statistical analysis was performed by analysis of variance. ${ }^{9}$

Total circulating red cell volume was determined with $\mathrm{Cr}^{51}$ tagged erythrocytes. ${ }^{10}$ Each animal was anesthetized with ether and $0.2 \mathrm{ml}$ of a tagged red cell suspension was injected into the saphenous vein. A ten minute interval was allowed for mixing, after which blood was removed via cardiac aspiration and delivered into a heparinized tube. The $\mathrm{Cr}^{51}$ was assayed on a $1.0 \mathrm{ml}$ aliquot of this blood using a scintillation counter. Hematocrits were determined on the cardiac blood with heparinized capillary tubes.

Bovine growth hormone (Armour Lot 50109) having a potency of approximately 1.0 U.S.P. units per $\mathrm{mg}$ and containing less than 0.02 U.S.P. units per $\mathrm{mg}$ of TSH as a contaminant was dissolved in 0.85 per cent saline before injection. ACTH injection (Parke-Davis Corticotropin injection solution, Lot No. 35-98-1) containing $5 \mathrm{mg}$ aminoacetic acid per 40 units and standardized in terms of U.S.P. corticotropin standard was dissolved in 0.85 per cent saline. The bovine thyroid stimulating hormone (TSH) preparation (Armour Lot No. 216-174-1) having a potency of approximately 0.9 U.S.P. units per $\mathrm{mg}$ and being negligibly contaminated with the remaining pituitary tropins was dissolved in 0.85 per cent saline. Each $\mathrm{ml}$ of N.F. adrenocortical extract (Parke-Davis Lot No. AJ 505) had a biological activity equivalent to that of 100 micrograms of U.S.P. hydrocortisone standard, contained less than 1 per cent of solid extractive material, was substantially free of the medullary hormone (less than one part in 1,000,000) and also contained 0.8 per cent sodium chloride. 17-hydroxycorticosterone acetate (Upjohn Lot No. LT697 GL), corticosterone (Upjohn Lot No. U-0569) were suspended in 0.85 per cent sodium chloride solution. d-aldosterone-21-acetate injectable (Ciba Lot No. E6409) was dissolved in sesame oil. Lyophilized crystals of angiotensin (Ciba-Hypertensin Lot No. E6286B) were dissolved in 0.85 per cent saline. 3,5,3'-triiodothyronine (Smith, Kline and French liothyronine sodium Lot No. RM 7310) was dissolved in $0.01 \mathrm{~N} \mathrm{NaOH}$ solution, placed in 0.85 per cent $\mathrm{NaCl}$ solution and $\mathrm{pH}$ adjusted to 9.0. An aqueous suspension of testosterone (Ayerst Labs Lot No. 545) containing 0.5 per cent acacia and 0.8 per cent $\mathrm{NaCl}$ was injected. Analytical grade cobaltous chloride hexahydrate (Matheson, Coleman \& Bell Lot No. 332188) with maximum impurity for lead of 0.005 per cent was dissolved in 0.85 per cent saline.

The oxygen consumptions were determined by a modified Watts and Gourley procedure $\mathrm{e}^{11}$ with a commercially available servo-activated apparatus. ${ }^{*}$ The oxygen consumption chamber contained a mixture of soda lime and calcium chloride as the carbon dioxide absorbent and desiccant and was partially immersed in a water bath maintained at $37^{\circ} \mathrm{C}$. After the rat was placed in the chamber, the gas cylinder of the spirometer was filled as the system was flushed with oxygen. After a 5 minute equilibration period, ten determinations, each of one minute's duration, were made with the animal resting quietly in the chamber. The mean was used for calculating $\mathrm{ml}$ oxygen consumed per 100 gram body weight per hour. Measurements were made during the afternoon 18-24 hours prior to the chromium-51 red cell volume determination.

\section{RESULTS}

1. Effects of anterior pituitary hormones on the incorporation of $\mathrm{Fe}^{59} \cdot \mathrm{Fe}^{59}$ incorporation in red cells was measured in hypophysectomized rats receiving saline, growth hormone

\footnotetext{
*Mouse Spirometer Model 160, obtained from Custom Engineering and Development Co., St. Louis, Missouri.
} 
( $4 \mathrm{mg} / \mathrm{kg}$ ), thyrotropic hormone $(4 \mathrm{mg} / \mathrm{kg})$, and ACTH $(25$ units $/ \mathrm{kg})$. Table 1 indicates the mean per cent radioactive iron incorporation in these four groups of rats.

$\mathrm{Fe}^{59}$ incorporation in both the ACTH and TSH treated rats was significantly greater than in saline injected controls. ACTH was the most potent of the anterior pituitary hormones assayed, which is in accord with the findings of Van Dyke et al. ${ }^{12,13}$ Growth hormone injections resulted in a slight but not significant elevation in $\mathrm{Fe}^{59}$ incorporation.

Table 1

EFFECTS OF SEVERAL HORMONES AND COBALT ON RADIOACTIVE IRON INCORPORATION IN RBC OF'HYPOPHYSECTOMIZED RATS

\begin{tabular}{|c|c|c|c|c|}
\hline Treatment & $\begin{array}{c}\text { Total dose } \\
\text { (per kg b.w.) }\end{array}$ & $\begin{array}{l}\text { No. } \\
\text { rats }\end{array}$ & $\begin{array}{l}\text { Body wt. } \\
\text { (g) }\end{array}$ & Per cent $\mathrm{Fe}^{59}$ incorporated \\
\hline \multicolumn{5}{|c|}{ Anterior pituitary hormones } \\
\hline Saline control & - & 25 & $138 \pm 4.9$ & $6.9 \pm 0.51$ \\
\hline Growth hormone & $4 \mathrm{mg}$ & 17 & $151 \pm 5.08$ & $8.4 \pm 1.27$ \\
\hline ACTH & 25 units & 10 & $127 \pm 2.61$ & $21.9 \pm 4.30^{*}$ \\
\hline TSH & $4 \mathrm{mg}$ & 10 & $118 \pm 2.56$ & $10.0 \pm 1.12 *$ \\
\hline \multicolumn{5}{|c|}{ Adrenocortical hormones } \\
\hline Adrenocortical extract ${ }^{2}$ & $380 \mu \mathrm{g}$ & 8 & $141 \pm 3.70$ & $12.2 \pm 2.5^{*}$ \\
\hline Corticosterone & $380 \mu \mathrm{g}$ & 5 & $151 \pm 2.86$ & $9.2 \pm 1.43$ \\
\hline Hydrocortisone acetate & $380 \mu \mathrm{g}$ & 5 & $157 \pm 1.50$ & $11.3 \pm 1.98^{*}$ \\
\hline Hydrocortisone acetate & $4000 \mu \mathrm{g}$ & 10 & $118 \pm 1.98$ & $4.3 \pm 0.46 *$ \\
\hline 11-dehydrocorticosterone & $380 \mu \mathrm{g}$ & 6 & $155 \pm 2.07$ & $11.3 \pm 0.96 *$ \\
\hline Aldosterone acetate & $380 \mu \mathrm{g}$ & 7 & $153 \pm 2.67$ & $6.3 \pm 0.87 *$ \\
\hline \multicolumn{5}{|c|}{ Thyroid hormone, testosterone and cobalt } \\
\hline $3,5,3^{\prime}$-triiodothyronine & $700 \mu \mathrm{g}$ & 16 & $113 \pm 1.73$ & $25.0 \pm 1.74 *$ \\
\hline Cobalt & $83 \mu \mathrm{M}$ & 10 & $139 \pm 7.02$ & $42.9 \pm 4.3^{*}$ \\
\hline Testosterone & $2 \mathrm{mg}$ & 5 & $166 \pm 2.32$ & $6.2 \pm 1.07$ \\
\hline
\end{tabular}

1. Divided into 2 daily injections.

2. $0.5 \mathrm{ml}$ adrenocortical extract per rat is equivalent to the biological activity of $380 \mu \mathrm{g} / \mathrm{kg}$ of hydrocortisone.

\pm Standard error of the mean.

* Means significantly different from hypophysectomized controls at the 5 per cent level.

2. Effects of adrenocortical steroids on the incorporation of $\mathrm{Fe}^{59}$. The mean radioactive iron incorporations in $\mathrm{RBC}$ of hypophysectomized rats receiving adrenocortical extract $(0.5 \mathrm{ml}$ per rat of $380 \mu \mathrm{g}$ hydrocortisone equivalent $/ \mathrm{kg}$ ), and $380 \mu \mathrm{g} / \mathrm{kg}$ respectively of corticosterone, hydrocortisone acetate, 11-dehydrocorticosterone and aldosterone acetate are given in Table 1. Adrenocortical extract, hydrocortisone acetate and 11-dehydrocorticosterone injections resulted in a significant increase in $\mathrm{Fe}^{59}$ incorporation. Corticosterone injections produced a slight but not significant increase in $\mathrm{Fe}^{59}$ incorporation. Adrenocortical extract was slightly more 
potent than either of the adrenocortical steroids tested separately. A dose of $4000 \mu \mathrm{g} / \mathrm{kg}$ of hydrocortisone acetate resulted in a significant decrease in $\mathrm{Fe}^{59}$ incorporation, while aldosterone acetate failed to produce any change.

3. Effects of thyroid hormone, testosterone and cobalt on $\mathrm{Fe}^{59}$ incorporation. Radioactive iron incorporations in $\mathrm{RBC}$ of hypophysectomized rats receiving 3,5,3'-triiodothyronine (700 $\mu \mathrm{g} / \mathrm{kg})$, cobaltous chloride $(83 \mu \mathrm{M} / \mathrm{kg})$ and testosterone $(2 \mathrm{mg} / \mathrm{kg})$ are also shown in Table 1. Cobalt and 3,5,3'-triiodothyronine injections resulted in significantly greater $\mathrm{Fe}^{59}$ incorporation than the saline treated controls and were the most potent compounds tested. Testosterone failed to produce a significant change in $\mathrm{Fe}^{59}$ incorporation which is in agreement with the findings of Prentice et al. ${ }^{5}$

4. Effects of angiotensin on $\mathrm{Fe}^{59}$ incorporation. The effects of angiotensin $(100 \mu \mathrm{g} / \mathrm{kg})$ on radioactive iron incorporation in RBC of hypophysectomized and hypophysectomized-adrenalectomized rats may be seen in Table 2. Angiotensin produced a significant elevation (123 per cent) in $\mathrm{Fe}^{59}$ incorporation when injected into hypophysectomized rats. When angiotensin was injected into the hypophysectomized-adrenalectomized rat, it also produced a slight but not slgnificant increase in $\mathrm{Fe}^{59}$ incorporation when compared with saline injected hypophysectomized-

Table 2

EFFECTS OF ANGIOTENSIN ON RADIOACTIVE IRON INCORPORATION IN RBC OF HYPOPHYSECTOMIZED AND HYPOPHYSECTOMIZED-ADRENALECTOMIZED RATS

\begin{tabular}{c|c|c|c}
\hline $\begin{array}{c}\text { Total dose angiotensin } \\
(\mu \mathrm{g} / \mathrm{kg}) 1\end{array}$ & $\begin{array}{c}\text { No. } \\
\text { rats }\end{array}$ & Body wt. (g) & Per cent Fe $\mathrm{F}^{59}$ incorporated \\
\hline \multicolumn{5}{c}{ Hypophysectomized } \\
\hline 0 & 17 & $143.6 \pm 3.92$ & $5.55 \pm 0.42$ \\
100 & 21 & $143.6 \pm 3.44$ & $12.5 \pm 1.12 *$ \\
\hline 0 & Hypophysectomized-adrenalectomized \\
\hline \multicolumn{6}{c}{} & 5 & $122.17 \pm 4.56$ & $.8 .0 \pm 1.27$ \\
\hline
\end{tabular}

1. Divided into 2 daily injections.

\pm Standard error of the mean.

* ' Means significantly different from either hypophysectomized or hypophysectomizedadrenalectomized controls at the 5 per cent level.

adrenalectomized controls. The baseline $\mathrm{Fe}^{59}$ incorporation in the hypophysectomized-adrenalectomized rats ( 8.0 per cent) was greater than the hypophysectomized controls (5.6 per cent). These results indicate that angiotensin stimulates erythropoiesis in the absence of the adrenals and therefore it may be concluded that the erythropoietic response to angiotensin is not entirely the result of its stimulatory action on the adrenal cortex.

5. Effects of hormones and cobalt on total circulating red cell volume and oxygen consumption. As may be seen from Table 3, hypophysectomized rats injected for 14 days with saline exhibited a significant decrease ( 8 per cent) in circulating RBC volume, accompanied by a significant decrease ( 28 per cent) in oxygen consumption. Hypophysectomized rats injected daily 
Table 3

INFLUENCE OF SEVERAL HORMONES AND COBALT ON TOTAL CIRCULATING RED CELL VOLUME, OXYGEN CONSUMPTION AND HEMATOCRIT IN HYPOPHYSECTOMIZED RATS

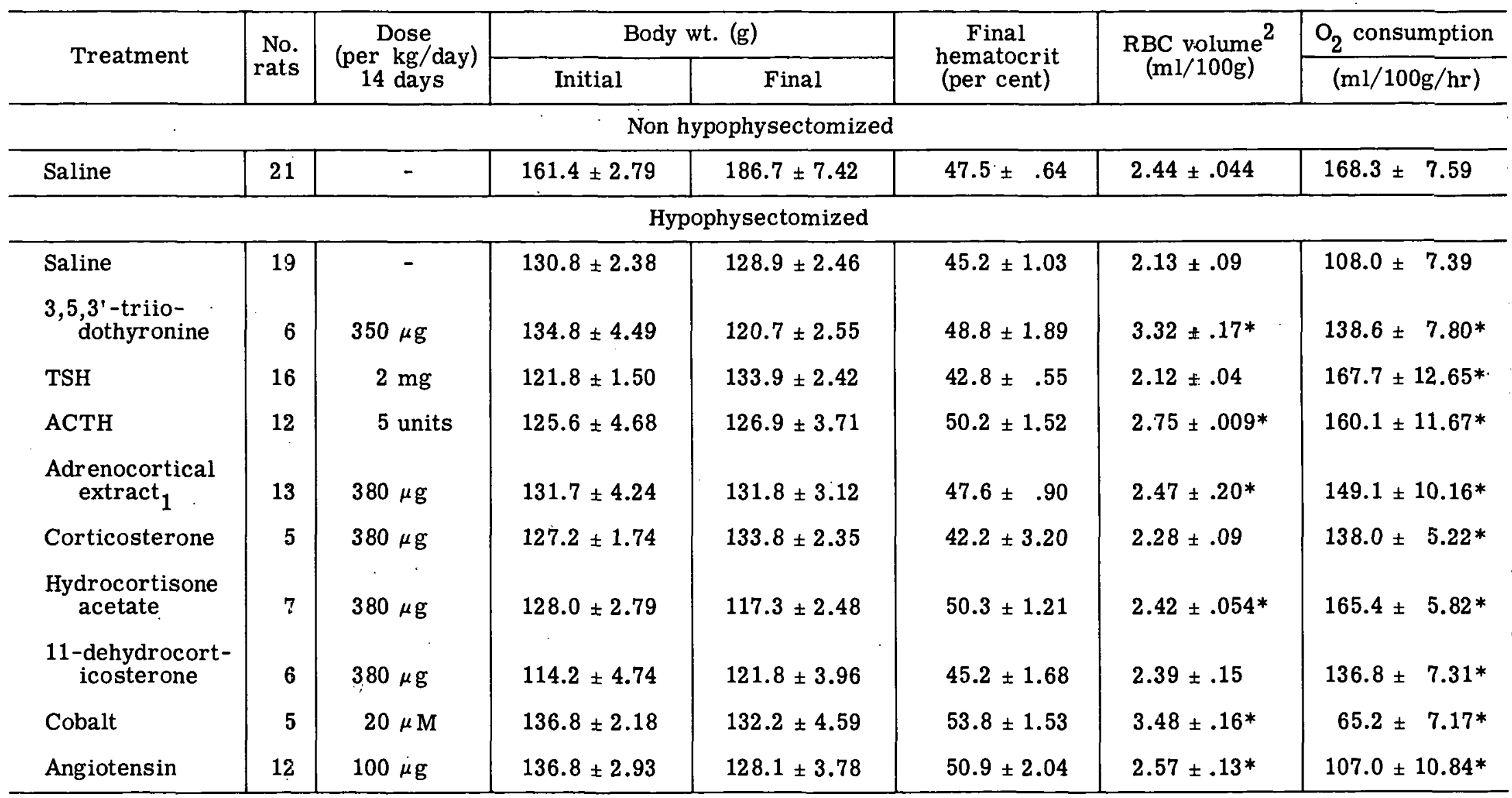

1. $0.5 \mathrm{ml}$ adrenocortical extract per rat is equivalent to the biological activity of $380 \mu \mathrm{g} / \mathrm{kg}$ of hydrscortisone standard.

\pm Standard error of the mean.

* Means significantly different from hypophysectomized controls at the 5 per cent level.

2. RBC volumes calculated on the basis of final body weight. 
for 14 days with $3,5,3^{\prime}$-triiodothyronine $(350 \mu \mathrm{g})$, ACTH (5 units), adrenocortical extract (0.5 ml per rat or $380 \mu \mathrm{g}$ hydrocortisone equivalent per $\mathrm{kg})$ and hydrocortisone acetate $(380 \mu \mathrm{g})$ induced a significant elevation in both RBC volume and oxygen consumption. Corticosterone and 11-dehydrocorticosterone produced a slight increase in RBC volume and a moderate elevation in oxygen consumption, while TSH failed to produce an elevation in RBC volume but resulted in a marked elevation in oxygen consumption.

$350 \mu \mathrm{g} / \mathrm{kg} /$ day of $3,5,3^{\prime}$-triiodothyronine appears to be quite toxic to hypophysectomized rats since four of the 10 rats injected died during the 14 days of treatment. This may account for the disproportionate rise in RBC volume compared with the increase in oxygen consumption. Treatment with angiotensin resulted in a significant increase in RBC volume but failed to elevate oxygen consumption. On the other hand, cobalt produced the most significant increase in RBC volume of any of the compounds tested but resulted in a significant depression of oxygen consumption. The effect of the thyroid, anterior pituitary and adrenocortical hormones on erythropoiesis is apparently correlated with their effect on oxygen consumption. On the other hand, cobalt and angiotensin must exert their effects on erythropoiesis through a mechanism which does not depend upon an increase in tissue oxygen demand.

\section{DISCUSSION}

The present study re-affirms and extends, using additional parameters, previous descriptions of the erythropoietic effects of $\mathrm{ACTH},{ }^{12,13}$ thyrotropic hormone, ${ }^{12}$ adrenocortical steroids, ${ }^{14,15,16}$ thyroid hormone, ${ }^{12,17}$ and cobaltous chloride ${ }^{18,22}$ in hypophysectomized rats. However, it is apparently the first report of an erythropoietic action of angiotensin. Approximately 123 per cent augmentation of $\mathrm{Fe}^{59}$ incorporation in $\mathrm{RBC}$ was found in hypophysectomized rats treated with angiotensin. The fact that angiotensin exerts an erythropoietic effect in hypophysectomized-adrenalectomized rats indicates that angiotensin is not dependent upon the adrenal cortex for its influence on erythropoiesis. Carpenter et al. ${ }^{19}$ found that angiotensin infusions into hypophysectomized-nephrectomized dogs resulted in the release of aldosterone and several other Porter-Silber chromagens. Our observations that adrenalectomy does not abolish the erythropoietic effect of angiotensin, that aldosterone does not stimulate erythropoiesis in the hypophysectomized rat and that angiotensin fails to stimulate oxygen consumption in hypophysectomized rats indicate that the effect of angiotensin on adrenocortical steroid release is independent of its effects on erythropoiesis. The juxtaglomerular apparatus is assumed to be the site of formation of renin, the protein which interacts with hypertensinogen to give rise to angiotensin. ${ }^{20}$ If this view is correct, renal ischemia produced by shock or experimental mechanical constriction of the kidney should result in an erythropoietic response. Mantz et al. ${ }^{21}$ found erythropoietic activity in blood from the renal vein after producing partial ischemia of the rat kidney.

The discharge of multiple target organ hormones has been postulated to explain the partial response of the nephrectomized animal to erythropoietic stimuli. ${ }^{3}$ Although none of the work included in the present study is concerned with the kidney per se it seems quite conceivable that one or more of the hormones assayed, with the exception of angiotensin, may be responsible for the erythropoietic response of the nephrectomized animal exposed to hypoxia. It would be interesting to know if hypoxic stimuli alone would provoke erythropoietin release in an animal in which nephrectomy has been combined with hypophysectomy, adrenalectomy or thyroidectomy.

Cobalt has been shown previously to repair the anemia of hypophysectomy. Furthermore 
the increase in red cell volume was of the same magnitude as that reported for normal rats. ${ }^{22}$ Cobalt injections also result in a significant elevation in plasma erythropoietin titers but fail to exert a characteristic erythropoietic effect in the absence of the kidney. ${ }^{18}$ Our finding that cobalt depresses oxygen consumption while increasing circulating red cell volume in hypophysectomized rats may help to explain how cobalt stimulates erythropoietin production. It has been postulated that the dynamic equilibrium of the erythron is regulated by erythropoietin in circulating blood, and that the quantity of this hormone is in some way determined by the relationship of tissue oxygen supply to oxygen demand. ${ }^{23}$ Cobalt may belong to the class of erythropoietic stimuli which produce histotoxic hypoxia, perhaps in the kidney, and may stimulate erythropoietin production by interfering with the metabolic oxygen requirements of this end organ. That adrenocortical extract as well as some individual corticoids stimulate $\mathrm{Fe}^{59}$ incorporation was not unexpected in view of previous work in which the corticoids produced an increase in RBC volume ${ }^{15}$ and a reticulocytosis. ${ }^{16}$ The erythropoietic activity of ACTH is hypophysectomized rats has been attributed by other investigators to the activity of the adrenal steroids. ${ }^{12}$ It is difficult to understand why a total dose of $380 \mu \mathrm{g}$ of hydrocortisone should produce an increase in $\mathrm{Fe}^{59}$ incorporation while the $4000 \mu \mathrm{g}$ dose resulted in a decrease, but the inhibitory effect of high doses of hydrocortisone may be related to the fact that large doses of cortisone inhibit protein synthesis. ${ }^{24}$

The mechanism by which the adrenocortical steroids stimulate erythropoiesis may be related to their effect on metabolic rate. Evans et al. ${ }^{25}$ have shown that ACTH increases metabolic rate in the hypophysectomized rat in the absence of the thyroid, but not in the absence of adrenals. In addition, these investigators found that hydrocortisone, injected into hypophysectomized rats, elevates the suppressed basal metabolic rate. The glucocorticoids tested in the present study produce a significant increase in oxygen consumption in the hypophysectomized rat. These steroids may produce an imbalance in the ratio of oxygen supply to demand and thus stimulate red cell formation by the same mechanism as that postulated for thyroxin. ${ }^{17}$

At present one can only speculate concerning the nature of the erythropoietically active substances found by Gurney et al. ${ }^{26}$ in human plasma. This activity was lost after boiling the plas$\mathrm{ma}$ and filtering the precipitate. The stimulatory effect of human plasma in the hypophysectomized, but not in the starved rat, may be due to the presence of anterior pituitary, thyroid and adrenocortical hormones. We find the hypophysectomized rat more sensitive to the erythropoietic effects of those hormones than the starved rat.

The primary site of action of the thyroid and adrenocortical hormones in stimulating erythropoiesis is not presently known. Cobalt apparently exerts its action through release of kidney erythropoietin. ${ }^{18}$ Utilizing recently developed technics for maintaining the life of nephrectomized animals, it should be possible to assay the corticoids and thyroid hormones in this preparation. It is also possible that these hormones exert a direct effect on erythroid tissue unrelated to their effects on metabolic rate. In this regard it would be of interest to know if these hormones could stimulate erythroid hyperplasia when perfused through the bone marrow of an isolated hind limb. ?

\section{ACKNOWLEDGMENTS}

The authors gratefully acknowledge the technical assistance of Mr. Douglas Kirkpatrick of the Argonne Cancer Research Hospital and of Mrs. Judy Parker, Mrs. Betty Tsakonas and Mr. 
Dan Knight of the University of Tennessee. We are indebted to Dr. Leon O. Jacobson for providing us with space and facilities at the Argonne Cancer Research Hospital; to Dr. Joseph Fisher, Armour Pharmaceutical Labs., for the growth hormone and TSH; to Dr. J. E. Gajewski, Parke, Davis \& Co., for the ACTH and adrenocortical extract; to A. F. Siegle, Smith, Kline \& French Labs., for the 3,5,3'-triiodothyronine; to Dr. William E. Wagner, Ciba Pharmaceutical Co., for the angiotensin and aldosterone acetate and to Dr. D. A. Shepherd, The Upjohn Co., for the hydrocortisone acetate, corticosterone and 11-dehydrocorticosterone.

\section{LITERATURE CITED}

1. Jacobson, L. O., E. Goldwasser, W. Fried, and L. Plzak. Nature, Lond., 179:633, 1957.

2. Goldwasser, E., W. Fried, and L. O. Jacobson. J. Lab. Clin. Med., 52:375, 1958.

3. Fisher, J. W., and B. J. Birdwell. Acta Haemat., 26:224, 1961.

4. Kuratowski, Z., B. Lewartowski, and E. Michalob. Bull. de l'acad. polonaise des sci., 8: $77,1960$.

5. Mirand, E. A., T. C. Prentice, and W. R. Slaunwhite. Ann. N. Y. Acad. Sci., 77:677, 1959.

6. Erslev, A. J. Ann. N. Y. Acad. Sci., 77:627, 1959.

7. Gallagher, N. I., J. M. McCarthy, and R. D. Lange. J. Lab. Clin. Med., 57:281, 1961.

8. Fried, W., L. F. Plzak, L. O. Jacobson, and E. Goldwasser. Proc. Soc. Exptl. Biol. Med., $92: 203,1956$.

9. Snedecor, G. W. Statistical Methods, 5th edition, Ames, Iowa State College Press, 1956, pp. 237-90.

10. Gray, S., and K. Sterling. J. Clin. Invest., 29:1614, 1950.

11. Watts, D. T., and D. R. H. Gourley. Proc. Soc. Exptl. Biol. Med., 84:585, 1953.

12. Van Dyke, D. C. Ann. N. Y. Acad. Sci., 77:543, 1959.

13. Garcia, J. F., D. C. Van Dyke, R. L. Huff, P. J. Elmlinger, and J. M. Oda. Proc. Soc. Exptl. Biol. Med., 76:707, 1951.

14. Fruhman, O. J., and A. S. Gordon. Acta. Haemat., 15:249, 1956.

15. Fisher, J. W. Proc. Soc. Exptl. Biol. Med., 97:502, 1958.

16. Gley, P., and J. Delor. Compt. Rend. Soc. Biol., 149:635, 1955.

17. Meineke, H. A., and R. C. Crafts. Proc. Soc. Exptl. Biol. Med., 102:121, 1959.

18. Goldwasser, E., L. O. Jacobson, W. Fried, and L. F. Plzak. Blood, 13:55, 1958.

19. Carpenter, C. C. J., J. O. Davis, and C. R. Ayers. Fed. Proc., 20:178, 1961.

20. Goormaghtigh, N. La fonction endocrine des arterioles renales. Son role dans la pathogenie de I' hypertension arterielle. Louvain, R. Fontayn, 1944.

21. Mantz, J. M., M. Cholevas, and J. Warter. Compt. Rend. Soc. Biol., 154:1068, 1960.

22. Garcia, J. F., D. C. Van Dyke, and N. I. Berlin. Proc. Soc. Exptl. Biol. Med., 80:472, 1952.

23. Fried, W., L. F. Plzak, L. O. Jacobson, and E. Goldwasser. Proc. Soc. Exptl. Biol. Med., $94: 237,1957$. 
24. Allfrey, V., A. E. Mirsky, and S. Osawa. The Chemical Basis of Heredity, Baltimore, Md., The Johns Hopkins Press, 1957, p. 209.

25. Evans, E. E., A. N. Contopoulos, and M. E. Simpson. Endocrinology, 60:403, 1957.

26. Gurney, C. W., and C. P. Pan. J. Lab. Clin. Med., 55:67, 1960. 


\section{THE LACK OF EFFECT OF PLASMA ERYTHROPOIETIN_ON-FORMATE INCORPORATION INTO NUCLEIC ACIDS IN VITRO* \\ By}

P. P. Dukes and E. Goldwasser

- Recently, Perretta and Thomson ${ }^{1}$ published an interesting report on the marked stimulatory action exerted by a preparation of erythropoietin on the incorporation of carbon-14-labeled formate into the bases of spleen and liver-slice nucleic acids. This same preparation, they reported, had no such action on marrow suspensions incubated under the same conditions. Since this finding appeared to offer a valuable approach to the biochemical study of the mechanism of action of erythropoietin and might also furnish a rapid, sensitive in vitro assay for the hurmone we undertook a confirmatory investigation. In place of the extract of alcohol-precipitated urine from anemic rabbits we used a partially purified sheep plasma fraction, with the results summarized below. These data do not confirm the findings of Perretta and Thomson.

Experimental details were essentially as reported by Perretta and Thomson with the following exceptions: as a source of erythropoietin, we used what we have termed the Step III frac$\operatorname{tion}^{2}$ which has an activity of about 3 units per $\mathrm{mg}$, the concentration used being $15 \mathrm{units} / \mathrm{ml}$, and the incubation time 130 minutes. The isolation and determination of specific activities of the purines and thymine were as described by Smellie et al. ${ }^{3}$ with some slight modifications. All samples were run in duplicate and the averages are reported.

It is clear from the data in Table 1 that we observed no marked stimulation of formate incorporation by any of the tissues. In the case of spleen RNA and marrow RNA and DNA, in fact, we observed some depression of incorporation as a result of incubation with the erythropoietincontaining material.

Among the differences between the experiments reported previously and those here, the most important may be differences in the amounts of erythropoietin used and in the non-erythropoietic contaminants in the two preparations. Although we do not know how much erythropoietin activity was used by Perretta and Thomson, our own experience in another experiment in which 5 and 10 units per $\mathrm{ml}$ were used, rather than 15 units per $\mathrm{ml}$ as in the experiment reported in Table 1, suggests no consistent dose effect.

We feel that the clue to the discrepancies we have seen may lie in the nature of the contaminants present in the preparations. The data reported by Perretta and Thomson show an appreciable depression of bone marrow formate incorporation caused by the control preparation from normal urine. This same extract caused no stimulation when incubated with spleen or liver slices. When the "anemic urine extract" was used the incorporation of formate of the marrow suspension was at about the normal level while there were large increases in the specific activities of the purines and thymine of spleen and liver. These data suggest that the "anemic urine extract" contained a substance which stimulated formate incorporation in all three tissues, that the marrow was sensitive to an inhibitory material present in both urine
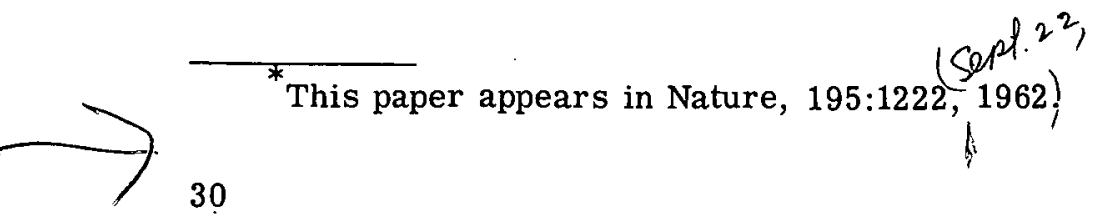

*This paper appears in Nature, 195:1222, 1962) 
extracts, and that the "anemic urine extract" was able to overcome the inhibitor action. If these inferences are correct, then the difference Perretta and Thomson observed between spleen and liver on one hand and marrow on the other was quantitative, and the stimulation observed was not the result of erythropoietin action.

Table 1

EFFECT OF ERYTHROPOIETIN ON INCORPORATION OF LABELED FORMATE INTO NUCLEIC ACID

BASES IN VITRO

\begin{tabular}{l|l|c|c|c|r}
\hline \multirow{2}{*}{ Tissue } & \multirow{2}{*}{ Base } & \multicolumn{2}{|c|}{ ANA } & \multicolumn{2}{c}{ DNA } \\
& & \multicolumn{2}{|c|}{$\mathrm{cpm} / \mu \mathrm{mole}$} & \multicolumn{2}{c}{ A $\mathrm{cpm} / \mu \mathrm{mole}$} \\
\hline \multirow{5}{*}{ Liver } & Guanine & 676 & 792 & 36 & 49 \\
& Adenine & 2087 & 2645 & 52 & 56 \\
& Thymine & - & - & 275 & 256 \\
& Guanine & 548 & 175 & 29 & 36 \\
& Adenine & 1330 & 576 & 18 & 21 \\
& Thymine & - & - & 56 & 69 \\
& Guanine & 735 & 180 & 364 & 201 \\
& Adenine & 1838 & 807 & 115 & 70 \\
& Thymine & - & - & 628 & 413 \\
\hline
\end{tabular}

$0.15 \mathrm{ml}$ packed marrow cells, $270 \mathrm{mg}$ of slices of liver or spleen per sample; formate concentration, $9.6 \mu$ moles $/ \mathrm{ml}(4.85 \mu \mathrm{C} / \mathrm{ml})$ incubation time 130' $\quad A=$ no added erythropoietin

$B=15$ units $/ \mathrm{ml}$ erythropoietin

\section{LITERATURE CITED}

1. Perretta, M. A., and R. Y. Thomson. Nature, 190:912, 1961.

2. White, W. F., C. W. Gurney, E. Goldwasser, and L. O. Jacobson. Recent Progress in Hormone Research, 16:219, 1960.

3. Smellie, R. M. S., R. Y. Thomson, and J. N. Davidson. Biochim. Biophys. Acta, 29:59, 1958. 


\title{
FURTHER PURIFICATION OF SHEEP PLASMA ERYTHROPOIETIN ${ }^{*}$
}

By

\author{
E. Goldwasser, W. F. White, ${ }^{\dagger}$ and K. B. Taylor ${ }^{\ddagger}$
}

In the past few years there has been a considerable revival of interest in erythropoietin, the hormone which stimulates the formation of red blood cells. The introduction of a relatively short assay method ${ }^{1}$ has made it feasible to attempt purification of this hormone, which in a purified state might be used for the treatment of some anemias, and will be of great value in studies of the early stages of red cell differentiation.

Although much evidence points to the kidney as the site of formation of erythropoietin, ${ }^{2,3}$ kidney extracts have only feeble erythropoietic activity, and plasma from anemic animals has been our source of the hormone. Recently there have been some studies on urinary crythrupoietin, especially of human origin, ${ }^{4,5}$ but as yet there is no body of evidence relating the properties of plasma and urinary hormones. The partial purification of rabbit plasma erythropoietin, which in general seems to resemble the sheep hormone, has been described. ${ }^{6,7}$

In previous communications from these laboratories we have reported on the partial purification of sheep plasma erythropoietin and on some properties of these preparations. ${ }^{8,9}$ This report is concerned with further progress in the purification of this hormone.

\section{MATERIALS AND METHODS}

The production of plasma from phenylhydrazine-treated sheep and several stages of its purification using ion-exchange methods have already been described. ${ }^{8}$. The four-day assay method, based on measurement of incorporation of radioiron into newly formed red cells in the fasted rat was used as previously described ${ }^{1,8}$ with one modification. Sprague-Dawley male rats weighing between 165 and $195 \mathrm{~g}$ before the start of the fasting period were selected for assay purposes.

One unit of erythropoietic activity has been defined as that amount of material which, when injected into rats under the standardized conditions of assay, will give rise to an increment of iron incorporation (over control values) equal to that given by $5 \mu$ moles of $\mathrm{CoCl}_{2}$ administered under the same conditions. ${ }^{8,10}$ We have chosen to retain this definition of a unit of activity rather than adopt the one proposed recently ${ }^{11}$ which is based on a fixed percentage of incorporation, since we feel that the latter fails to allow for the variable sensitivity from assay to assay. Each assay included a standardized preparation, or cobaltous chloride at 2 or more dose levels in order to evaluate activity in units, and interpolation was done from a plot of increment of per cent incorporation of $\mathrm{Fe}^{59}$ vs $\log$ of dose.

DEAE cellulose was obtained from the Brown Paper Co., XE-97 resin from Rohm and Haas,

\footnotetext{
*This paper will appear in Biochem. et Biophys. Acta, 64:487, 1962.

${ }^{\dagger}$ Research Department, Armour and Co., Chicago. Present address: Abbott Laboratories, North Chicago, Illinois.

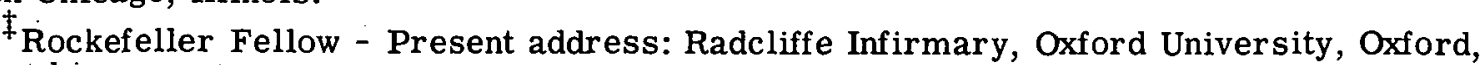
England.
} 
Bio-Rex 70 from Bio-Rad Laboratories, $\mathrm{Fe}^{59} \mathrm{Cl}_{3}$ from Abbott Laboratories and complete Freund adjuvant from Difco Laboratories. Hydroxylapatite was prepared according to the method of Tiselius ${ }^{12}$ and calcium phosphate gel by the method of Tsuboi and Hudson. ${ }^{13}$

The methods of both Lowry ${ }^{14}$ and Westley and Lambeth ${ }^{15}$ were used for protein determinations, crystalline bovine serum albumin (Armour) serving as a standard. Sialic acid determinations were done by using Mauzerall and Granick's modification ${ }^{16}$ of the direct Ehrlich's reaction. ${ }^{17}$ This method was first standardized using a sample of human orosomucoid (11 per cent sialic acid) kindly supplied by Dr. Richard Winzler of the University of Illinois School of Medicine, after which a crude sample of sheep orosomucoid (8.7 per cent sialic acid) was used as a standard.

Total carbohydrate was determined with the carbazole reagent ${ }^{18}$ using an equimolar mixture of glucose, fructose, ribose, galactose and mannose as a standard. Hexoseamine was determined by the method of Blix. 19

Gel electrophoresis was essentially as described by Smithies ${ }^{20}$ but on a smaller scale and using polyacrylamide ${ }^{21}$ as the supporting medium.

$1.2 \mathrm{ml}$ of 10 per cent dimethylaminoproprionitrile and $1.2 \mathrm{ml}$ of 10 per cent ammonium persulfate were added to $100 \mathrm{ml}$ of filtered 5 per cent cyanogum $41^{*}$ in $0.081 \mathrm{M}$ tris, $0.003 \mathrm{M} \mathrm{Na}_{2}$ EDTA and $0.012 \mathrm{M}$ boric acid at $\mathrm{pH}$ 8.7. The solution was mixed and poured into plastic troughs $88 \mathrm{~mm} \times 15 \mathrm{~mm} \times 4.5 \mathrm{~mm}$, covered with a strip of Parafilm and allowed to stand until the gel was firm (1 hour). About $20 \mu \mathrm{g}$ of the sample in the same buffer was applied to a piece of Whatman No. 40 filter paper (about $2 \times 6 \mathrm{~mm}$ ), held on a piece of razor blade and inserted into a slit about $30 \mathrm{~mm}$ from one end of the gel. The bottom surface of the trough was immersed in an ice bath throughout this procedure and the subsequent electrophoresis. After the sample was in place, about $21 \mathrm{~mm}$ of gel were cut off each end leaving a $46 \mathrm{~mm}$ strip of gel and two wells in the trough. The wells were filled with $\mathrm{pH} 9.2$ buffer 10 times as concentrated as that used to prepare the gel, platinum wire electrodes were clipped in place at the ends, and 25 ma were applied to the gel (at constant current) for 15 minutes. After this time, the gel strip was immersed in 1 per cent Buffalo black in acetic acid, methanol, water $(1: 5: 5)(\mathrm{v} / \mathrm{v} / \mathrm{v})$ for 2 minutes. The gel was then washed free of stain with several changes of the same solvent mixture. The somewhat dehydrated gel was next immersed in a 7.5 per cent acetic acid, 30 per cent glycerol mixture until it had regained its original transparency, at which time photographs were made.

Rabbits were immunized against partially purified erythropoietin (Step III) as follows: 50 $\mathrm{mg}$ of the erythropoietin concentrate was dissolved in $2.5 \mathrm{ml}$ of $0.15 \mathrm{M} \mathrm{NaCl} ; 7.5 \mathrm{ml}$ of complete Freund adjuvant was added and the mixture emulsified for 5 minutes by ejection from a 10-ml syringe through a wide-bore cannula. The emulsified antigens were given in doses of $50 \mathrm{mg}$ per rabbit by multiple simultaneous intramuscular and subcutaneous injections in the dorsal region between the scapulae. Each rabbit received 2 sets of injections 12 days apart. The antisera were collected 30 days after the second injection.

A similar procedure (but eliminating the second set of injections) was used with guinea pigs for the preparation of anti-sheep- $a-1$ glycoprotein.

Immuno-diffusion experiments were done on microscope slides using 1 per cent Ionagar $\dagger$

\footnotetext{
'Cyanogum 41 is a mixture of acrylamide and $N, N^{\prime}$-methylene-bis acrylamide made by American Cyanamid Co. and sold by E. C. Corporation.

†Consolidated Laboratories.
} 
containing 1 per cent sodium azide. After allowing time for diffusion, the agar gels were placed into $0.15 \mathrm{M} \mathrm{NaCl}$ in the cold overnight to remove the unprecipitated proteins. The washed gels were then stained with the same dye used for the polyacrylamide gels, washed free of dye with methanol, acetic acid, water $(5: 1: 5)(\mathrm{v} / \mathrm{v} / \mathrm{v})$ and allowed to dry in air to a very thin, tough film tightly adhering to the glass slide. The slides were then placed in a photographic enlarger and negative prints were made of the stained precipitin bands.

Preparation of starting material. The modified large scale production of erythropoietin concentrates by the pilot plant of the Armour Pharmaceutical Co. is carried out according to the following brief outline. The process differs in some respects from the three step method previously published, ${ }^{8}$ and the authors are indebted to Dr. Russel Kutz of the Armour Pharmaceutical Co. for details of these procedures. ${ }^{*}$

Fifty liters of the chilled plasma obtained from phenylhydrazine-treated sheep was brought to $\mathrm{pH} 4.5$ and dialyzed against 5 volumes of cold water for 12 hours. $750 \mathrm{~g}$ of DEAE cellulose, previously washed to remove fines and equilibrated with $0.0375 \mathrm{M} \mathrm{NaCl}: 0.025 \mathrm{M} \mathrm{NaH}_{2} \mathrm{PO}_{4}$ at pH 4.5, was added to the plasma, mixed for 90 minutes, the DEAE collected on a Büchner funnel, and washed with the same buffer until the $A_{280}$ of the wash was less than 0.2. Elution was done with $0.5 \mathrm{M} \mathrm{NaCl}: 0.1 \mathrm{M} \mathrm{Na}_{2} \mathrm{H} \mathrm{PO}_{4}$ until the $\mathrm{A}_{280}$ was less than 0.2; the eluate was dialyzed against water for 48 hours and lyophilized. This fraction is called Step I. The potency of Step I is usually about 0.5 to $1.0 \mathrm{units} / \mathrm{mg}$ of protein and the recovery of activity about $60-65$ per cent. The Step I fraction was dissolved in 10 volumes of $0.02 \mathrm{M} \mathrm{NaH}_{2} \mathrm{PO}_{4}: 0.18 \mathrm{M} \mathrm{NaCl}$ buffer at $\mathrm{pH} 6.0$ and added to a $15 \times 60 \mathrm{~cm}$ column of washed $\mathrm{XE}-97$ resin equilibrated at $\mathrm{pH} 6.0$. The input to the column was followed by the same buffer until the effluent $\mathrm{A}_{280}$ was less than 0.2 . The total effluent, usually 6-9 L, contains the erythropoietin fraction termed Step II. 'I'his fraction is no longer accumulated as such and therefore no characterization of the pilot plant material is available. This procedure used to obtain Step $\Pi$, as indicated in a previous paper, ${ }^{8}$ serves to remove much of the pyrogenic material contaminating Step I.

Step II effluent was immediately brought to $\mathrm{pH} 5.0$ and run through a smaller $(7.5 \times 45 \mathrm{~cm})$ column of $\mathrm{XE}-97$ equilibrated at $\mathrm{pH}$ 5.0. At this stage the active hormone is adsorbed by the resin. Elution is carried out as a batch process by raising the pH to 6.05 with $5 \mathrm{~N} \mathrm{NaOH}$ using an autotitrator over about a one-hour period. This eluate is dialyzed, lyophilized and is termed Step III. Step III potency is usually in the range 2-4 units/mg protein. A comparison of Step I and Step III fractions by gel electrophoresis is seen in Figure 1. Although in moving boundary electrophoresis Step III erythropoietin appears to be homogeneous at $\mathrm{pH} 8.0$ as shown in earlier work, ${ }^{8}$ the higher resolving power of the gel method makes clear the heterogeneity of this fraction.

Typical results of the combined ion-exchange purification methods are presented in Table 1 which shows an overall purification of about 400 -fold by these methods, with a recovery of about 35 per cent of the starting activity.

\section{RESULTS AND DISCUSSION}

When used to immunize rabbits, the Step III erythropoietin fraction proved to be antigenic,

The large scale production of erythropoietin concentrates was done under Contract H-5393-Cl between the U. S. Public Health Service and the University of Chicago. 

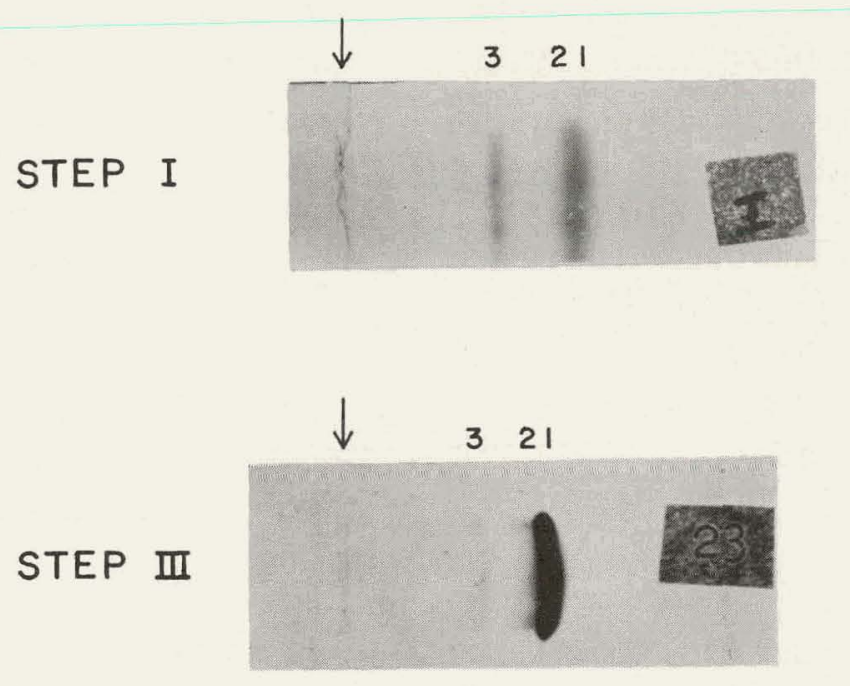

STEP IV

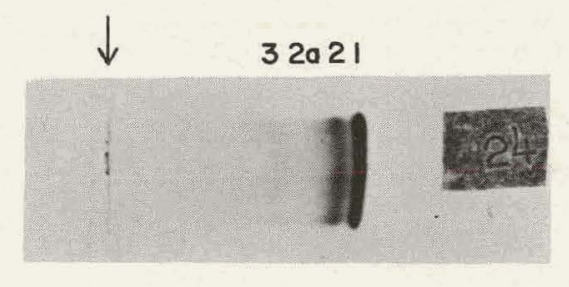

STEP $\mathbb{Z}$

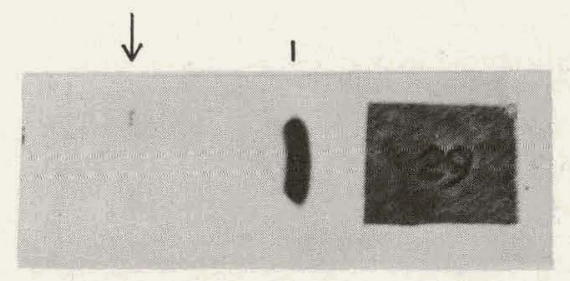

Figure 1. Gel electrophoresis of sheep plasma erythropoietin fractions. Arrows indicate starting positions. The numbers assigned to the various bands are arbitrary designations. All bands with the same number have been shown to have the same migratory rate.

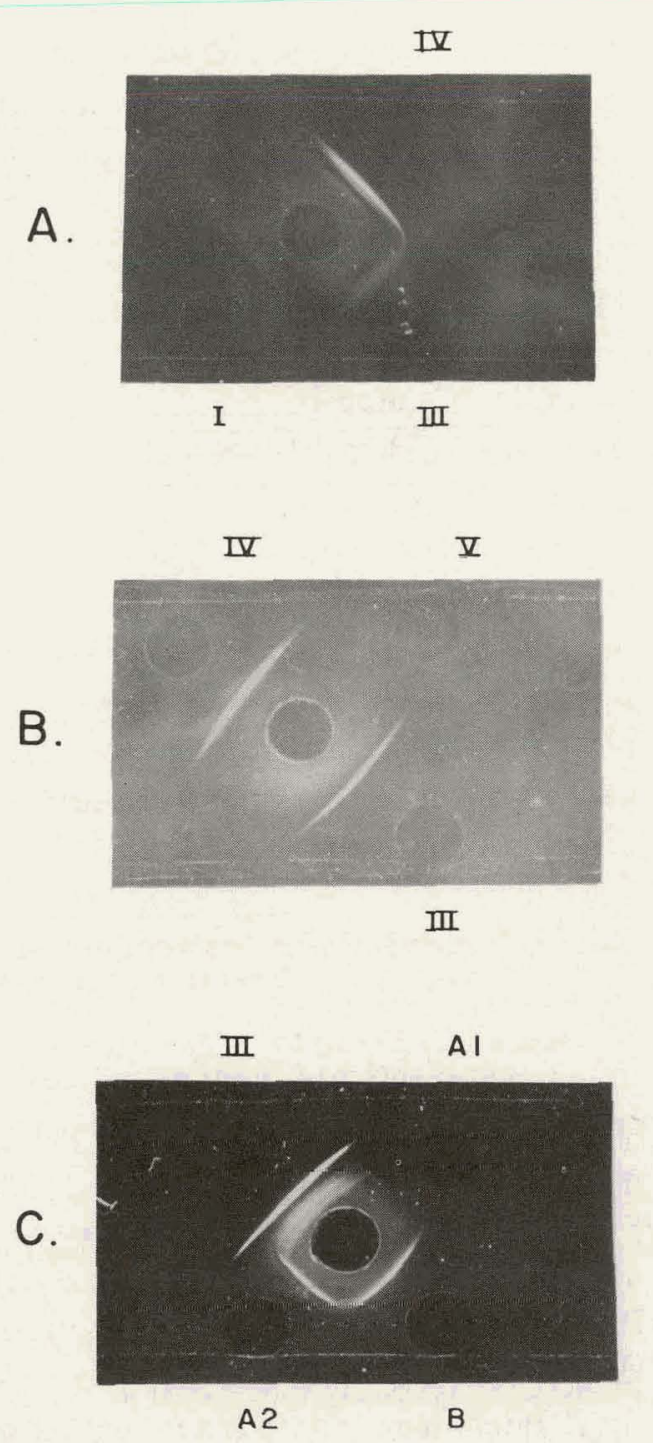

Figure 2. Immuno-diffusion of erythropoietin fractions. In each case the antiserum is in the central well and test substances are in peripheral wells.

giving rise to easily detectable precipitins (see Fig. 2). Neither precipitating nor neutralizing antibodies toward the active erythropoietin were demonstrated, however. When $1.5 \mathrm{ml}$ of antiserum and 10 units of the Step III fraction were mixed under conditions allowing precipitation of the antigen-antibody complex, the full activity was recovered in the supernatant fraction (Table 2). The table includes a control experiment done with normal serum since a small precipitate was observed when Step III and normal serum were mixed. In other experiments with widely differing ratios of antiserum to antigen the activity was always recovered almost completely in the supernatant, even when there was maximal precipitin formed. While these data do not rule out the possibility that a soluble complex did form which was dissociated upon injection in- 
Table 1

RESULTS OF TYPICAL LARGE SCALE PURIFICATION OF

50 LITERS OF ANEMIC SHEEP PLASMA

\begin{tabular}{l|c|l|c|c}
\hline \multicolumn{1}{c|}{ Fraction } & $\begin{array}{c}\text { Yield } \\
(\mathrm{g})\end{array}$ & $\begin{array}{c}\text { Units } / \mathrm{mg} \\
\text { protein }\end{array}$ & $\begin{array}{c}\text { Recovery } \\
\text { (per cent) }\end{array}$ & Purification \\
\hline Original plasma & 4000 & 0.007 & 100 & - \\
Step I & 22.5 & 0.8 & 64 & $112 \mathrm{X}$ \\
Step III & 3.3 & 3.0 & 35 & $430 \mathrm{X}$ \\
\hline
\end{tabular}

Table 2

TEST OF RABBIT ANTI-STEP III SERUM

\begin{tabular}{l|c|c}
\hline & $\begin{array}{c}\text { Anti-serum } \\
\text { (units) }\end{array}$ & $\begin{array}{c}\text { Normal serum } \\
\text { (units) }\end{array}$ \\
\hline Precipitate & 0.5 & 0.0 \\
Supernate & 6.5 & 7.0 \\
\hline
\end{tabular}

Precipitates were suspended in $0.15 \mathrm{M} \mathrm{NaCl}$. All injections for assay were done subcutaneously.

to the assay animals, further studies with the agar-gel immuno-diffusion technique demonstrated a vanishingly small amount of precipitin band formation with more highly purified fractions and the antiserum.

The anti-step III serum was used as a qualitative indicator of non-erythropoietin, antigenic materials by the immuno-diffusion technique. A comparison of such analyses of the various fractions will be discussed below. Preliminary experiments using partially purified antibody as a means of removing impurities have not yet yielded any fraction with increased specific activity.

Ammonium sulfate fractionation was carried out in the cold on Step III at a concentration of about $20 \mathrm{mg} / \mathrm{ml}$. At 0.53 saturation with ammonium sulfate at $\mathrm{pH} 6.3$ the precipitate had low activity; when the ammonium sulfate concentration was brought to 0.67 saturated at $\mathrm{pH} 3.3 \mathrm{a}$ second precipitate formed which contained about one-half the starting activity while the supernatant contained only a small fraction of the activity. The results of such a fractionation are summarized in Table 3. The 0.67 saturated precipitate obtained by this method we have termed Step IV. The overall purification factor at this stage is 4300 with a recovery of about 17 per cent of the original activity. Comparisons of Step I, III and IV by gel electrophoresis and by immuno-diffusion are shown in Figures 1 and $2 \mathrm{~A}$ and B.

When the fractions were examined by gel electrophoresis (Fig. 1) we could see that the ammonium sulfate procedure resulted in a lowered amount of component \#1, an increase in \#2 and the appearance of a component (\#2a) not previously seen. From data presented below it will be clear that neither component ( 2 nor $2 \mathrm{a}$ ) seems to be erythropoietin but that they appear to be only contaminants concentrated by the same procedures as the active hormone.

Immuno-diffusion revealed several antigenic materials still present in Step IV, despite the three- to four-fold increase in specific activity accompanying the loss of about 95 per cent of 
Table 3

AMMONIUM SULFATE FRACTIONATION OF STEP III ERYTHROPOIETIN

\begin{tabular}{l|c|c|c}
\hline \multicolumn{1}{c|}{ Fraction } & $\begin{array}{c}\text { Wt. } \\
\text { (g) }\end{array}$ & Units/mg protein & $\begin{array}{c}\text { Recovery of activity } \\
\text { (per cent) }\end{array}$ \\
\hline Step III & 6.09 & 8.9 & 100 \\
0.53 sat. pH 5.7 ppt. & 2.10 & 4.4 & 17 \\
0.67 sat. pH 3.3 ppt. & 0.89 & 30.0 & 49 \\
Supernate & - & 1.0 & $\frac{15}{81}$ \\
& & \multicolumn{2}{|c}{ overall recovery } \\
\hline
\end{tabular}

the protein of the Step III fraction.

In our previous work ${ }^{8}$ we had shown that Step III erythropoietin when chromatographed on $\mathrm{XE}-97$ according to the method of Schmid, ${ }^{8 \mathrm{a}}$ gave rise to a large amount of an inert $a_{1}$ acidic glycoprotein which seemed to be sheep orosomucoid, and a smaller active fraction which was eluted from the column with the $a_{2}$ glycoproteins and which we termed fraction 4B. We had also demonstrated that fraction $4 \mathrm{~B}$ was free of orosomucoid, but since the large scale method of purification described above is different from the earlier published method, this question was re-examined. The guinea pig anti-sheep $a_{1}$ glycoprotein serum was used as an indicator in immuno-diffusion and we found no indication of any precipitin band with the Step IV fraction under conditions where there was a band visible with the sheep orosomucoid.

Chromatography of Step IV on hydroxylapatite was carried out with the results shown in Figure 3. Of the 6 peaks obtained only the unadsorbed fraction (A) had erythropoietin at a higher specific activity than the starting material. This fraction usually contained about 5-10 per cent of the original protein and 30-50 per cent of its activity. When the A fraction was divided into two rough-

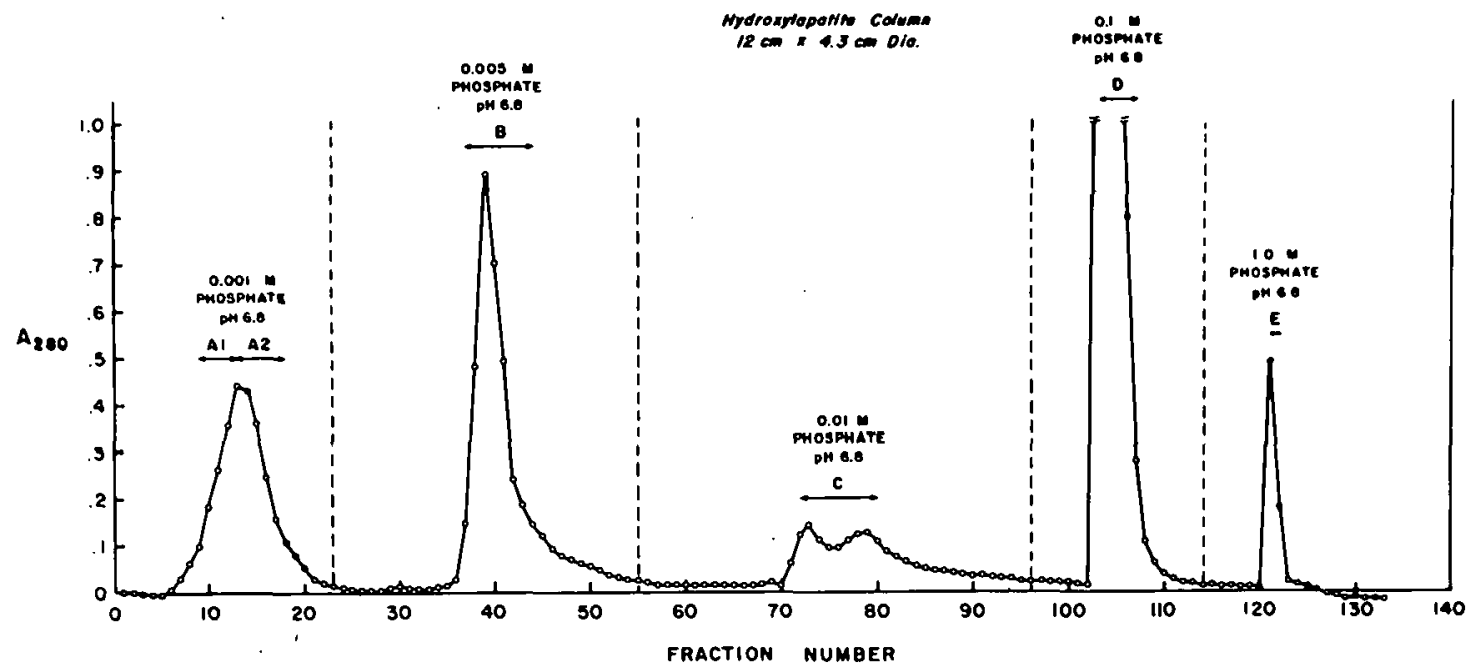

Figure 3. Hydroxylapatite chromatography of Step IV. Chromatography of Step IV erythropoictin on hydroxylapatile. Vertical broken lines indicate buffer changes. Horizontal arrows indicate fractions pooled for assay. 
ly equal parts, the leading half of the peak (A1) showed a significantly higher specific activity (150 units/mg protein) than did the trailing half (A2) (46 units/mg protein). The reason for this could be clearly seen when the two A fractions were compared with each other and with the B fraction from the same column by immuno-diffusion ( $\mathrm{Fig} .2 \mathrm{C}$ ). It is evident that some of the material represented by fraction B is present in A2, while A1 seems to be devoid of any antigenic material.

Since supplies of the Step III and Step IV fractions were severely limited we were forced to use the less active fractions derived from the ammonium sulfate process for further work. ${ }^{*}$ In order to arrive at a potency approximately the same as that of Step IV, we subjected the supernatant fraction, which has a potency of about $1 \mathrm{unit} / \mathrm{mg}$ protein, to chromatography on the cation exchange resin Bio-Rex 70, with the results seen in Figure 4. Contrary to expectations, the active fraction came off the column in the input buffer, somewhat retarded from the main protein peak. When the resin XE-97 (IRC-50) (which is very similar to Bio-Rex 70) was used for chromatography of Step III $^{8}$ the active fraction came off in the second buffer. This difference in chromatographic behavior we found to be due to differences between the supernatant fraction and Step III caused by the low $\mathrm{pH}$ ammonium sulfate procedure since upon chromatography of the latter on Bio-Rex 70 the active fraction was eluted only by the second buffer as with IRC-50.

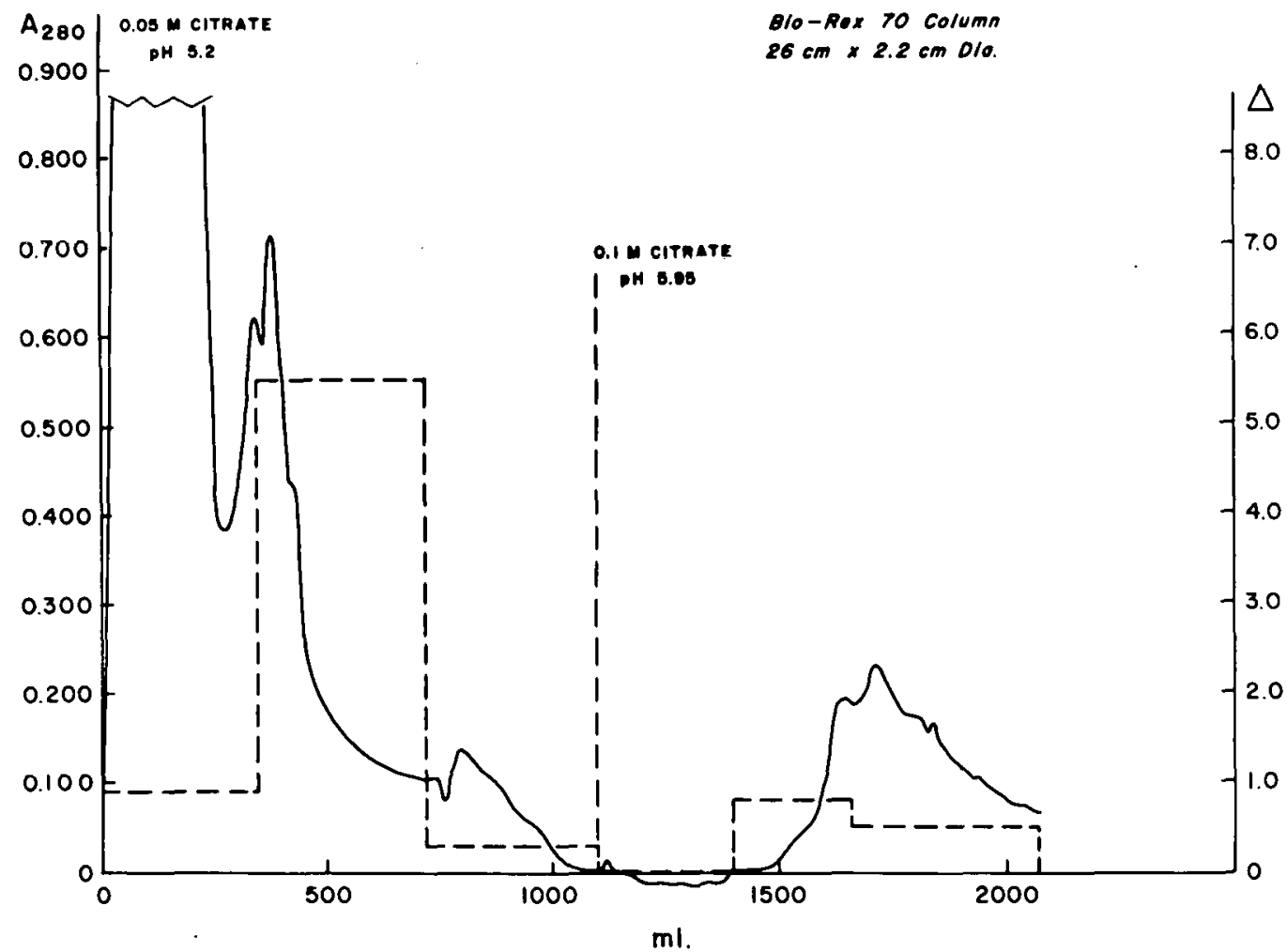

Figure 4. Chromatography of ammonium sulfate supernatant fraction on cation exchanger Bio-Rex-70. Chromatography of ammonium sulfate supernatant fraction on cation exchanger Bio-Rex-70. Right hand ordinate refers to assay values of pooled fractions indicated by broken line. Unbroken line indicates $\mathrm{A}_{280}$.

${ }^{*}$ We are grateful to the U.S. Public Health Service Study Section on Hematology for a supply of these fractions allocated to one of us (E.G.). 
Because of the lack of sharp resolution on hydroxylapatite and because of other difficulties in the use of this adsorbent we attempted further fractionation of the erythropoietin concentrate from the Bio-Rex 70 column using calcium phosphate gel in a batch process. Ten $\mathrm{ml}$ of the gel suspension in water at a dry weight concentration of $11.0 \mathrm{mg} / \mathrm{ml}$ was centrifuged to the bottom of a glass tube. The salt-free ${ }^{*}$ protein solution was added to the packed gel and mixed with it for one-half hour in the cold, after which the gel was removed by centrifugation. The supernatant from the first gel adsorption was pipetted on to a second gel pellet and the process repeated. Results of such a fractionation are shown in Figure 5. Under these conditions about one-half the active material remains in solution while about 95 per cent of the $280 \mathrm{~m} \mu$ absorbing material is taken out of the solution. Attempts to elute active material from the gel have not yet been successful. The purification factor obtained by this method is about 15 -fold. When the calcium

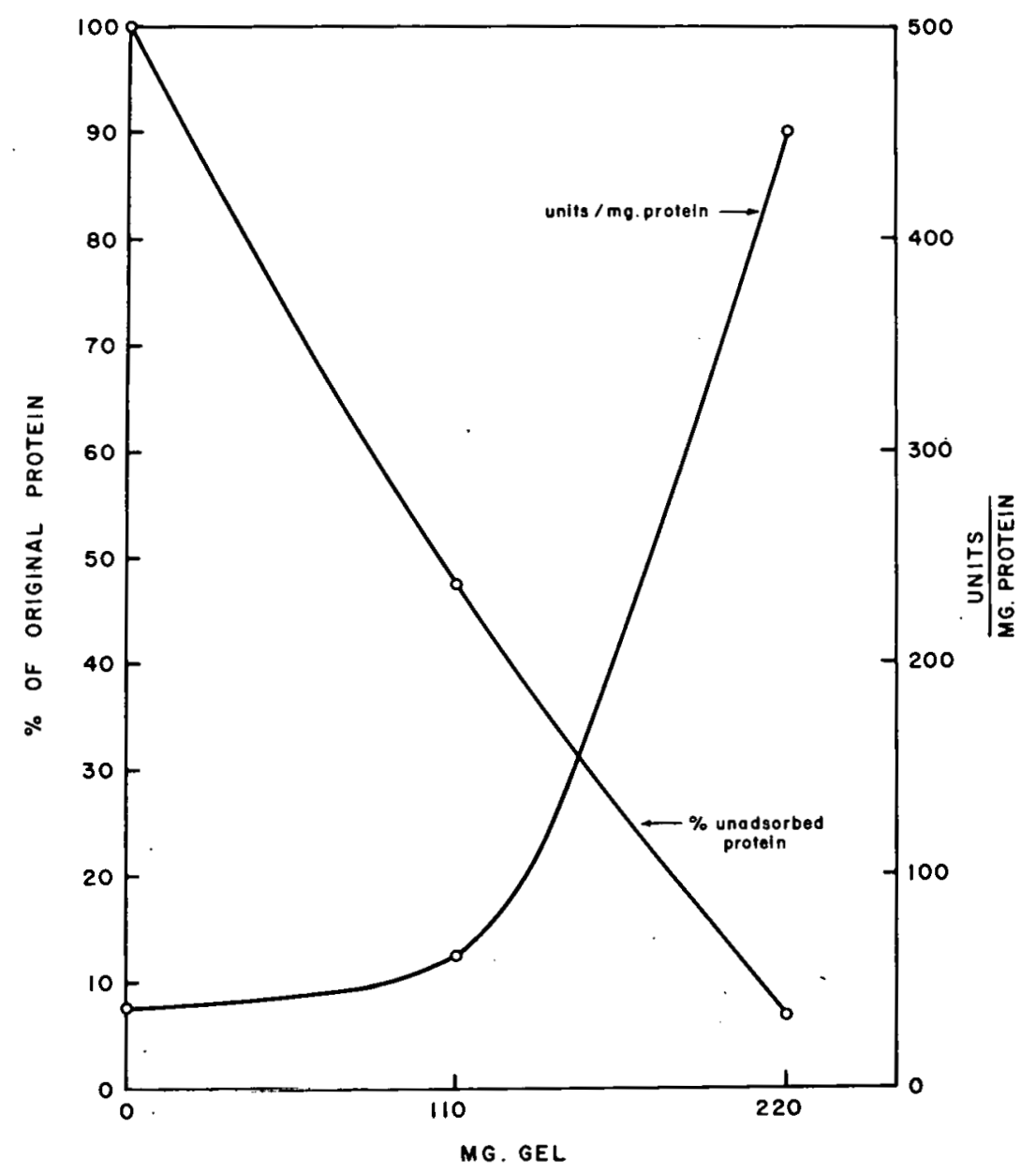

Figure 5. Calcium phosphate gel fractionation of erythropoietin.

\footnotetext{
*With fractions obtained from columns by the use of citrate buffers it may be necessary to use electrodialysis to reduce the citrate concentration to a level low enough for successful gel adsorption.
} 
phosphate gel supernatant (Step V) at 450 units/mg protein is compared to the original plasma at $0.007 \mathrm{units} / \mathrm{mg}$ protein the overall purification factor is 64000 . Unfortunately, no good estimate of recovery of original activity is available since the calcium phosphate gel procedure was done on a side fraction of the ammonium sulfate fractionation. If we could assume similar recovery from Step IV as from the Bio-Rex eluate the overall yield of activity would be 8-9 per cent.

The very small amount of Step V obtained in these gel adsorption experiments permitted examination of only a few of its properties. In Figure 1 it can be seen that gel electrophoresis shows only one component for Step V as against 4 or more for Step IV. When comparisons with cruder fractions were made we found that the single electrophorietic component was identical with that band labeled \#1. There is a very faint band present in the immuno-diffusion against anti-Step III serum which unfortunately was not apparent upon photographing the dried film.

Some chemical properties of the Step V fraction are summarized in Table 4 as compared with the Step IV fraction and with the A1 fraction previously described. Noteworthy in these pre-

Table 4

SOME PROPERTIES OF ERYTHROPOIETIN FRACTIONS

\begin{tabular}{|c|c|c|c|c|c|c|c|}
\hline Fraction & $\lambda_{(\mathrm{m} \mu)}^{\lambda \max }$ & $\begin{array}{c}\text { A } 1 \text { per cent } \\
280\end{array}$ & $\begin{array}{r}\operatorname{Pr} \\
\text { Lowry } \\
(\%)\end{array}$ & $\begin{array}{l}\text { tein } \\
\text { Westley } \\
(\%)\end{array}$ & $\underset{(\%)}{\text { Carbohydrate }}$ & $\begin{array}{c}\text { Hexoseamine } \\
(\%)\end{array}$ & $\begin{array}{l}\text { Sialic acid } \\
(\%)\end{array}$ \\
\hline Step IV & 275 & 5.1 & 71.5 & 67.3 & 9.3 & 10.0 & 7.5 \\
\hline A 1 & $\begin{array}{l}265 \\
275\end{array}$ & 4.7 & 36.8 & 55.1 & 12.5 & 13.8 & 18.4 \\
\hline Step V & 270 & 10.0 & 80.8 & 68.1 & 29.2 & 17.5 & 13.0 \\
\hline
\end{tabular}

liminary analytical values of Step $V$ are: a) The large amount of carbohydrate; b) The relatively low wave length of the adsorption maximum; and c) The high value of the 1 per cent absorbancy coefficient. The absorption spectrum of Step V is shown in Figure 6. The large shift toward the red at high $\mathrm{pH}$ indicates a high tyrosine content and a low (if any) tryptophan content for this mucoprotein and serves to explain the large discrepancy between the values for protein obtained by the Westley and Lambeth method and Lowry method. Since bovine serum albumin was used as a standard it would be expected that proteins with higher tyrosine content would give higher.values. The Westley and Lambeth method, which does not differentiate proteins on the basis of aromatic amino acids, would be expected to give a truer indication of the protein content except where the non-protein moiety may bind copper.

Although we recognize that the methods described here may not have led to a pure hormone, we feel that a report at this stage is justified since further purification may be very slow owing to the severely limited amounts of crude materials which are available. As more starting material becomes available we will accumulate enough Step V erythropoietin to attempt further fractionation to do more critical tests of homogeneity and to study in greater detail its chemical and physical properties. 


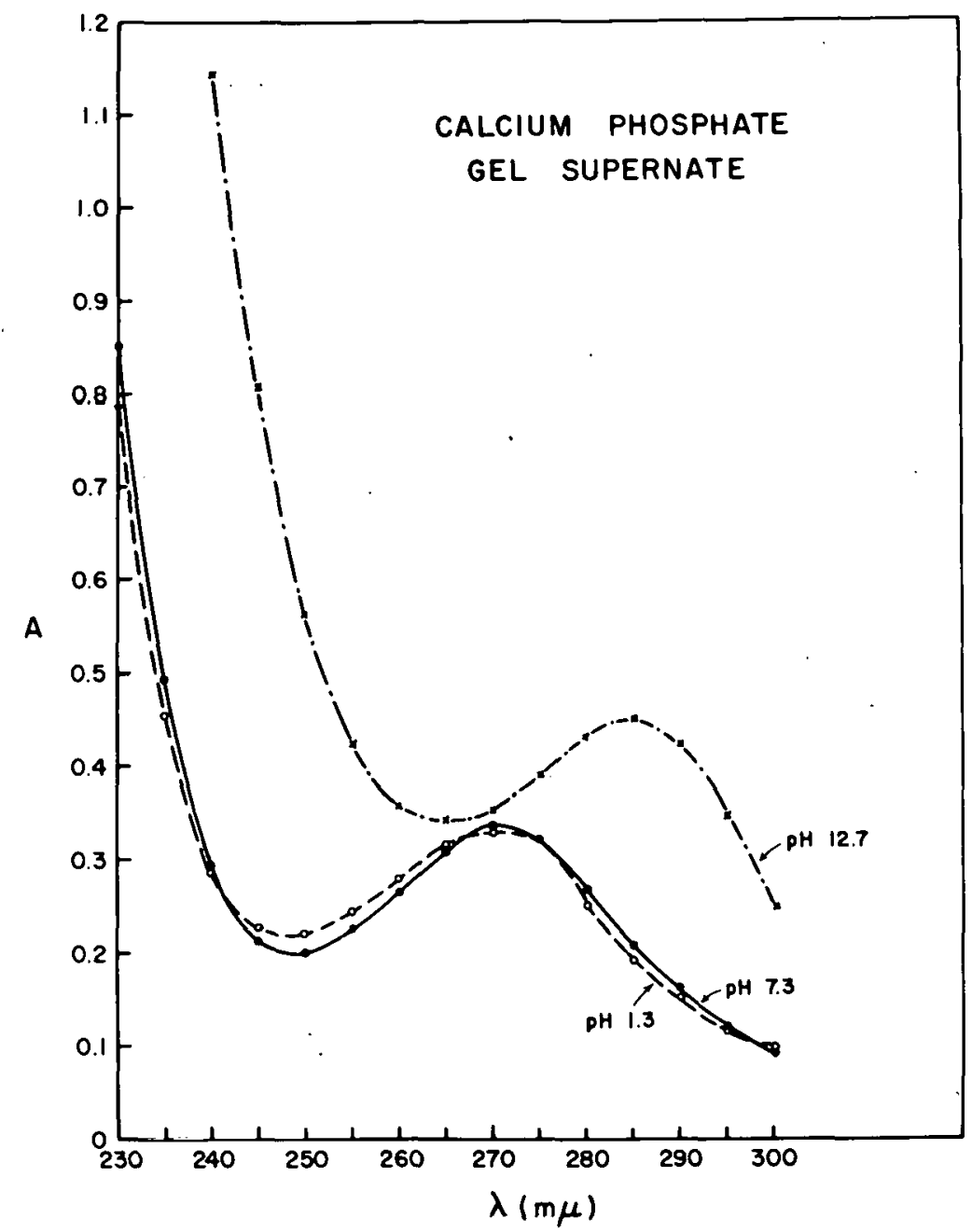

Figure 6. Ultraviolet absorption spectrum of Step V erythropoietin.

\section{LITERATURE CITED}

1. Fried, W., L. F. Plzak, L. O. Jacobson, and E. Goldwasser. Proc. Soc. Exptl. Biol. Med., $92: 203,1957$.

2. Jacobson, L. O., E. Goldwasser, W. Fried, and L. F. Plzak. Trans. Assoc. Am. Physcns., $70: 305,1957$.

3. Kuratowska, Z., B. Lewartowski, and E. Michalak. Bull. Acad. Polonaise des Sciences, 8: $77,1960$.

4. Winkert, J., A. S. Gordon, S. J. Piliero, and P. T. Medici. Proc. Soc. Exptl. Biol. Med., 98:351, 1958.

5. Hodgson, G., S. Fischer, M. Peretta, I. Eskuche, G. Araya, and M. Dinamarca. Blood, 16: 1398,1960 .

6. Lowy, P. H., G. Keighley, H. Bor sook, and A. Graybiel. Blood, 14:262, 1959.

7. Rambach, W. A., H. Alt, and J. Cooper. Proc. Soc. Exptl. Biol Med., 98:602, 1958. 
8. White, W. F., C. W. Gurney, E. Goldwasser, and L. O. Jacobson. In G. Pincus, ed., Recent Progress in Hormone Research, Vol. XVI, New York: Academic Press, Inc., 1960, p. 219.

8a. Schmid, K., M. B. MacNair, and A. I. Burgi. J. Biol. Chem., 230:853, 1958.

9. Campbell, B. J., R. J. Schlueter, G. F. Weber, and W. F. White. Biochim. Biophys. Acta, 46:279, 1961.

10. Goldwasser, E., and W. F. White. Federation Proc., 18:236, 1959.

11. Keighley, G., P. H. Lowy, H. Borsook, E. Goldwasser, A. S. Fordon, T. C. Prentice, W. A. Rambach, F. Stohlman, and D. C. Van Dyke. Blood, 16:1424, 1960.

12. Tiselius, A., S. Hjerten, and Ö. Levin. Arch. Biochem. and Biophys., 65:132, 1956.

13. Tsuboi, K. K., and P. B. Hudson. J. Biol. Chem., 224:879, 1957.

14. Lowry, O. H., N. J. Rosebrough, A. L. Farr, and R. J. Randall. J. Biol. Chem., 193:265, 1951.

15. Westley, J., and J. Lambeth. Biochim. Biophys. Acta, 40:364, 1960.

16. Mauzerall, D., and S. Granick. J. Biol. Chem., 219:435, 1956.

17. Werner, I., and L. Odin. Acta Soc. Med. Uppsaliensis, 57:230, 1952.

18. Ashwell, G. In S. Colowick and N. Kaplan, eds., Enzymology, Vol. III, New York: Academic Press, Inc., 1957, p. 80.

19. Blix, G. Acta Chem. Scand., 2:467, 1948.

20. Smithies, O. Biochem. J., 61:629, 1955.

21. Raymond, S., and L. Weintraub. Science, 130:711, 1959. 


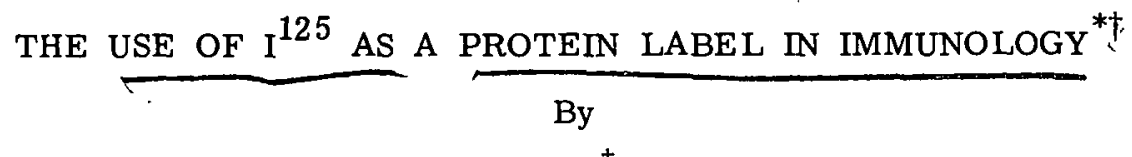

F. W. Fitch, J. Winebright, ${ }^{\ddagger}$ and P. V. Harper, Jr.

Of the various radioisotopes which have been used to study tissue and cellular localization and metabolic fate of antigens, $\mathrm{C}^{14}, \mathrm{H}^{3}$, and $\mathrm{S}^{35}$ have the disadvantage of being recycled into many tissue components and in addition only $\mathrm{H}^{3}$ gives high resolution autoradiographs.

Radioactive iodine has a number of advantages as such a label. It can be coupled readily with proteins through a stable chemical bond, and the metabolic degradation products are rapidly excreted with virtually no recycling of the label. ${ }^{1}$ There is little change in immunologic activity of labeled proteins if only a few iodine atoms are introduced into the protein molecule. ${ }^{2}$ $\mathrm{I}^{131}$ has been used in most studies although $\mathrm{I}^{130}$ and $\mathrm{I}^{133}$ have also been employed. ${ }^{3}$ These isotopes emit rather high energy $\beta$ particles and $\gamma$ rays, and although they have been used in radioautographic studies, the high energy of the $\beta$ particles does not allow precise localization.

$\mathrm{I}^{125}$, which may be prepared by thermal neutron activation of xenon, ${ }^{4}$ decays by electron capture followed by a $0.035 \mathrm{KEV} \gamma$ transition. The principal photon radiations, 27.3 to $35.5 \mathrm{KEV}$, may be detected in tissue and serum samples with 30 to 40 per cent efficiency using an ordinary well crystal scintillation counter. Accompanying the photon radiation are low energy conversion and Auger electrons which have the same general energy range as the tritium beta radiation 5 permitting precise autoradiographic localization. The half-life of 60 days provides long shelflife for labeled materials, and the low energy dissipation rate, approximately 15 per cent that of $\mathrm{I}^{131}$, greatly reduces radiation damage to tagged compounds. $\mathrm{I}^{125}$ is available commercially, carrier-free in high purity at reasonable cost. ${ }^{*}$

Formalin-killed Salmonella typhosa bacilli were iodinated with $\mathrm{I}^{125}$ using the general method previously described. ${ }^{6}$ In the final vaccine suspension, 98 per cent of the radioactivity was protein-bound, and there were $3.4 \times 10^{6} \mathrm{cpm}$ and $1 \times 10^{9}$ organisms $/ \mathrm{ml}$. Five rats were given single intravenous injections of $1 \mathrm{ml}$ of the labeled vaccine. Two were killed 15 minutes after injection and tissues were sampled for measurement of radioactivity and for autoradiography. An average of 77 per cent of the injected radioactivity was present in the liver and 2.5 per cent in the spleen. The level in the liver is somewhat higher and that in the spleen somewhat lower than with $\mathrm{I}^{13}{ }$-labeled typhoid vaccine. ${ }^{6}$ The remaining three animals were bled on the 6 th and 8th day after injection of labeled vaccine, and agglutinin titers compared with those found in normal rats injected with unlabeled vaccine. Agglutinins were determined using doubled dilution of serum and unlabeled typhoid vaccine as antigen. The agglutinin level for the two groups differed by less than one tube dilution at both intervals after immunization. Autoradiographs were prepared from $6 \mu$ paraffin sections of liver and spleen using Kodak Fine Grain Autoradi*This report is taken from a paper appearing in Science, 135:1068, 1962.)
${ }^{\dagger}$ Work supported in part by U.S. Public Health Service Medical Training Grant 15, 2E-96.
${ }^{\ddagger}$ Department of Pathology, University of Chicago.
${ }^{* *}$ Isotope Sales Division, Oak Ridge National Laboratory, Oak Ridge, Tennessee and Nu-
clear Science and Engineering Corporation, Pittsburgh, Pennsylvania. 
ography Stripping Plate, AR 10, and an exposure time of one week. Sections were lightly stained with $\mathrm{H}$ and $\mathrm{E}$ after developing the emulsion. The results are compared in Figure 1 with previous studies using $\mathrm{I}^{131}$-labeled typhoid vaccine and Eastman Nuclear Track Plates type NTB for autoradiography. ${ }^{6}$ The clusters of silver grains are smaller and more discrete in the autoradio-

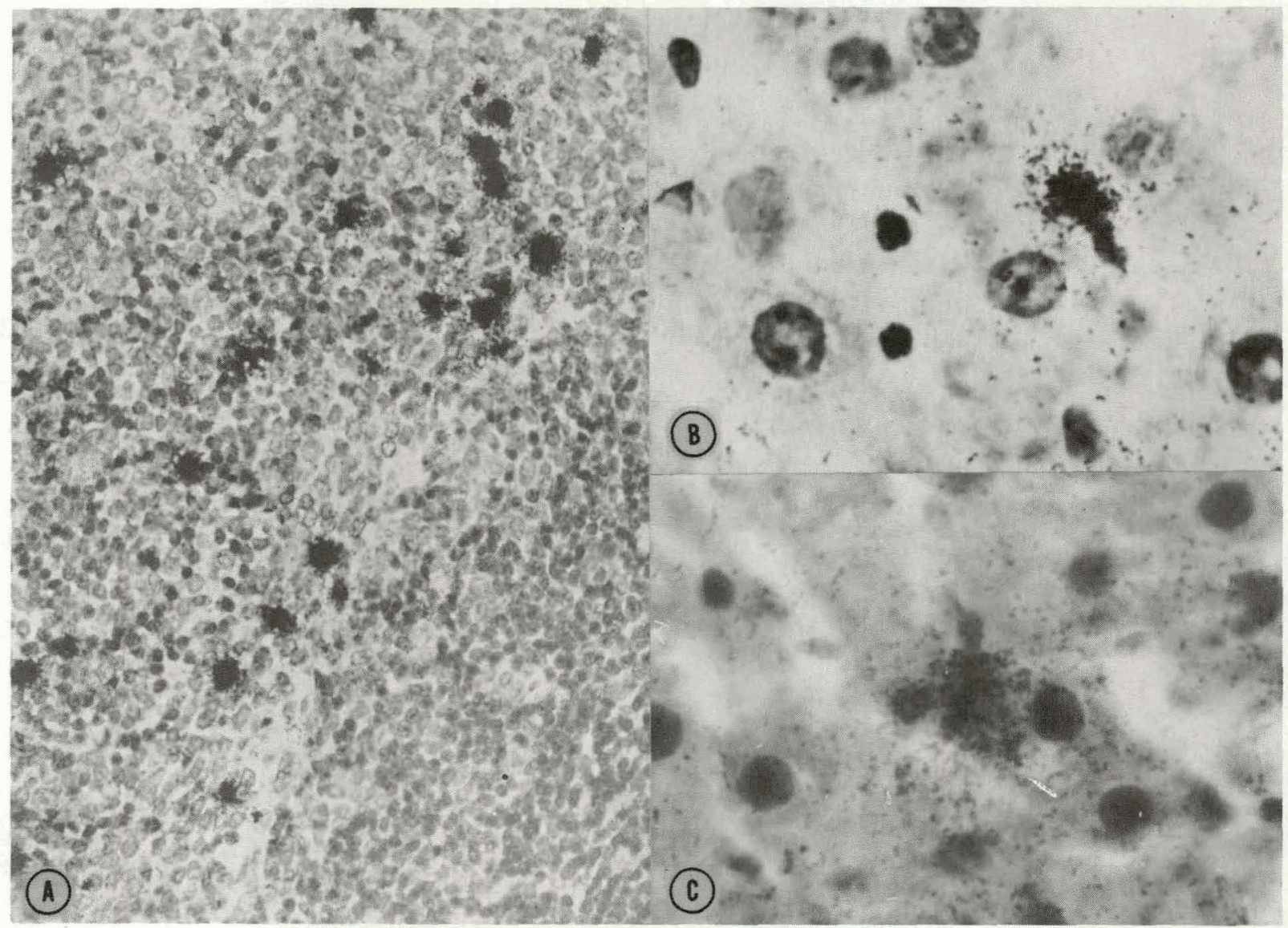

Figure 1. (A) Microscopic section of rat spleen 15 minutes after intravenous injection of I 125 -tagged typhoid bacilli. Autoradiograph prepared with Kodak Fine Grain Autoradiography Stripping Plate, AR 10 using one week exposure. Section stained with $\mathrm{H}$ and $\mathrm{E}$ (Mag x 385). A lymphoid follicle is in the lower right corner. Radioactivity is located mainly in the marginal zone. Grain clusters are small and discrete. (B) Microscopic section of liver from same rat as in A; autoradiograph prepared in the same manner (Mag x 1092). A discrete cluster of silver grains is located over a Kupffer cell. (C) Microscopic section of liver from rat 15 minutes after intravenous injection of $\mathrm{I}^{131}$-tagged typhoid bacilli. Autoradiograph prepared with Kodak NTB Nuclear Track Plate.6 Section stained with H and E (Mag x 1092). The cluster of silver grains is apparently located over a Kupffer cell although the scatter is too great to permit accurate localization.

graphs prepared after injection of the $\mathrm{I}^{125}$-labeled vaccine, and in the liver of these animals (Figure 1B), the clusters are definitely localized over single Kupfer cells. With shorter exposure time, grain counts can provide quantitative data as to the amount of antigen present. Although differences in the emulsions may contribute to some of the differences noted, this does not appear to be a major factor. Studies are now in progress using $\mathrm{I}^{125}$-tagged flagella to determine tissue and cellular localization and catabolism of these antigens. 


\section{LITERATURE CITED}

1. McFarlane, A. S. Ann. N. Y. Acad. Sci., 70:19, 1959.

2. Johnson, A., E. D. Day, and D. Pressman. J. Immunol., 84:213, 1960.

3. Day, E. D., J. A. Planinsek, and D. Pressman. J. Natl. Cancer Inst., 26:1321, 1961.

4. Harper, P. V., W. D. Siemens, K. A. Lathrop, and H. Endlich. J. Nucl. Med., in press.

5. Meyers, W. G., and J. C. Vanderleeden. J. Nucl. Med., 1:149, 1960.

6. Fitch, F. W., P. Barber, K. H. Soules, and R. W. Wissler. J. Lab. Clin. Med., 42:598, 1953, 


\section{ANTIBODY-EORMATION IN THE RAT. THE AGGLUTININ RESPONSE TO PARTICULATE AND SOLUBLE FORMS OF FLAGELLA PROTEIN FROM SALMONELLA TYPHOSA*}

By

F. W. Fitch and J. Winebright

Among factors known to influence the antibody response are a) the dose of the antigen, b) the route of its injection, c) the physical state of the antigenic material, d) the previous contact of the animal with the antigen, and 3) the presence or absence of the spleen. Although some studies indicate the importance of these variables in determining the pattern of antibody response, ${ }^{1-3}$ relatively few attempts have been made to examine their interrelationships. These experiments were undertaken to investigate the roles of these variables in the immune response of the rat.

The antigen selected was a purified flagellar preparation from Salmonella typhosa-a highly antigenic material which can be prepared in particulate or soluble form. The two forms are closely related chemically but differ markedly in physical properties. ${ }^{4}$ The effect of variation in dose and route of injection of the particulate flagella in intact and splenectomized rats was studied both after an initial antigen injection and after a second antigenic stimulus given 4 weeks later.

\section{MATERIALS AND METHODS}

Animals and care. Adult male Sprague-Dawley rats weighing $325-400$ g were randomly distributed in 36 groups of 5 rats each. They were given Purina Chow and water ad libitum. Eighteen groups were splenectomized on the day preceding antigen injection: the remaining eighteen groups were not subjected to surgery since preliminary experiments indicated that sham operation had no effect on the agglutinin response. Blood samples for antibody determinations were taken from the lateral tail vein. Splenectomy, antigen injection, and bleeding were all performed under ether anesthesia.

Antigen preparation. The flagella of Salmonella typhosa were prepared according to the method of Kobayashi et al. ${ }^{4} \mathrm{~S}$. typhosa serotype T-20 were grown on cellophane covered tryptic soy Agar. Formalin-killed organisms were vigorously agitated in a paint shaker for $10 \mathrm{~min}$ and the cell bodies separated by centrifugation in the cold at $500 \mathrm{x} / \mathrm{g}$. The flagella were purified using a combination of ammonium sulfate fractionation and differential ultracentrifugation. The nitrogen content was measured by Kjeldahl determination and flagella weight calculated as-

\footnotetext{
* This report will be published as the following two papers:

I. Agglutinin response to particulate flagella from Salmonella typhosa by J. Winebright ${ }^{\dagger}$ and F. W. Fitch, J. Immunol., 1962.

II. Agglutinin response to soluble flagellin from Salmonella typhosa by F. W. Fitch and J. Winebright, J. Immunol., 1962.

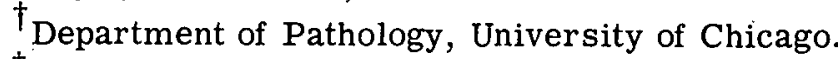

${ }^{\ddagger}$ John and Mary R. Markle Scholar in the Medical Sciences.
} 
suming nitrogen constituted 16 per cent of the material. ${ }^{4}$ Preparations used for immunization contained 1.6 per cent carbohydrate as measured using the anthrone reagent. ${ }^{5}$ This probably represents slight endotoxin contamination.

Flagellin was prepared from an aliquot of this flagella suspension. This preparation was acidified to $\mathrm{pH} 2$ by dropwise addition of $0.1 \mathrm{~N} \mathrm{HCl}$. After 30 minutes at room temperature, 0.1 $\mathrm{N} \mathrm{NaOH}$ was added to bring the $\mathrm{pH}$ to 7 . No further purification was attempted. This acid treatment caused loss of the turbidity and viscosity of the flagella suspension and resulted in a completely clear solution.

All dilutions of both antigens were made with distilled water.

Antibody determination. Although the rats were immunized with these two forms of the purified flagella; the antibody response to this antigen was measured by determining the agglutinin titer with the whole $\underline{S}$. typhosa organism. Preliminary experiments indicated that the agglutinin level measured in this way closely paralleled that measured by the hemagglutination of tanned sheep erythrocytes onto which flagellin was adsorbed.

The sera were stored in the frozen state until the conclusion of the experiment. Titrations were performed within two weeks. All of the sera obtained from one animal of each group during the primary response were titrated at one time; the sera obtained during the secondary response were titrated at a different time. Thus there were twenty separate series of antibody determinations. A reference antiserum was included in most of these determinations. Double dilution of serum was employed using an initial dilution of 1:10. Aliquots of the same bacterial suspension were used in all titrations. The tubes were centrifuged after 30 min incubation at room temperature, and the organisms resuspended by shaking. For some purposes the titer was expressed as the reciprocal of the highest dilution of serum containing grossly visible agglutinated organisms. For statistical analysis the titer was given as the number of the last tube containing grossly visible agglutination; this expresses the serum dilution as $10 \times 2^{n}$ where $n$ is the tube number.

Studies by Weinstein ${ }^{6}$ indicate that even in quite "pure" flagellar preparations there may be amounts of endotoxin capable of eliciting an antibody response. For this reason, antibody to the somatic antigenic components of $\mathbf{S}$. typhosa was measured. Agglutination of alcohol-killed and washed suspension of $\underline{S}$. typhosa $0-901$ was determined according to the method of Landy et al. ${ }^{7}$ Antibody against the somatic antigen was also measured using sheep erythrocytes sensitized with alkali and heat-treated lipopolysaccharide prepared from $\underline{S}$. typhosa $0-901 .{ }^{8,9}$

Experimental plan. Ninety rats were employed in the study of flagella and an equal number in the study of flagellin. Splenectomized and intact rats were immunized with $10 \mu \mathrm{g}, 0.1 \mu \mathrm{g}$ or $0.001 \mu \mathrm{g}$ of antigen given intravenously, intraperitoneally, or subcutaneously into the dorsum of the right hind foot. Representative groups of five splenectomized rats and five intact rats were injected by each of the three routes with each of the three doses. Each dose was contained in a volume of $0.2 \mathrm{ml}$; and an equal volume was injected regardless of the route of injection. A baseline bleeding was performed on the day preceding the immunization. Blood samples were then taken 4, 6, 8 and 16 days following this first injection. On the 27 th day a second "baseline" sample was obtained, and on the 28 th day all the animals were again injected via the same route and with the same antigen dose as before. Bleedings were obtained 4, 6 and 8 days following this second immunication. 
Statistical analysis. ${ }^{*}$ The geometric mean titer for each group of five animals was calculated and plotted against time in days after the initial injection (Figures 1-6).

Based on these curves, the following phases of the antibody response were selected for statistical analysis: 4 through 8 days ("early primary") and 16 through 27 days ("late primary") after the initial injection and 4 through 8 days ("secondary") after the second immunization (Tables 1 and 2). The mean tube number for these intervals was calculated for each rat, and the average as well as the standard error of the mean for each group of five animals was computed. A titer of 1:10 (tube number of 0 ) was arbitrarily assigned for those sera which did not agglutinate the bacteria at the lowest tested dilution. The apparently low value for the standard error of the mean at the $0.001 \mu \mathrm{g}$ dose of antigen is due to the fact that many of these animals had agglutinin titers of less than 1:20. Analysis of variance was therefore performed only on the data from the two highest dose levels.

Since the effect due to the presence or absence of the spleen interacted with one or more of the other variables, data from intact and splenectomized rats were considered separately. To evaluate secondary response, the difference between the mean tube number of each animal in the interval 4 to 8 days after the first antigen injection and that of the comparable period after secondary stimulation was determined. If this value was positive, it indicated a greater response after secondary stimulation; if negative, a lesser response.

The secondary response could also be evaluated by comparing the antibody level after primary stimulation with the increase in antibody titer after secondary stimulation above the base level at the time of second antigen injection. However, sera obtained before primary antigenic stimulation gave no agglutination at the lowest serum dilution tested. This precludes such a comparison since agglutinin titer was measured using logarithmic serum dilution.

\section{RESULTS}

Flagella. The agglutinin response of intact and splenectomized rats to flagellar antigen injected by three routes is shown graphically in Figures 1-3. In intact rats receiving larger amounts of antigen there was in general a sharp rise in titer reaching a peak on the 6th day after antigen injection, followed in most instances by an abrupt fall, and a slow, steady decline through the 27th day. After the second injection there was often a second rather rapid rise in titer, though not always to the levels reached after the initial injection.

Splenectomized rats on the other hand did not have such a swift or large rise in circulating antibody during the initial 8-day period after the first injection of antigen. The peak was usually reached during the second week and not by the end of the first week as in the intact rats. Levels during the third and fourth week after antigen injection were similar for both intact and splenectomized animals injected with the highest antigen dose by any route. Splenectomized rats receiving lower antigen doses had lower levels during this period than did similar intact rats.

After the second immunization of splenectomized rats there was a rise in agglutinin titer to levels exceeding those attained after the first injection. This pattern is different from that found in intact rats. The final level however, did not differ greatly in the two conditions.

The pattern of the agglutinin response was quite similar for all intact rats given the two

The authors gratefully acknowledge the assistance of Dr. Paul Meier and Mr. Jack Marshal in the statistical analysis of the data. 
higher doses of antigen regardless of the route of injection; only at the $0.001 \mu \mathrm{g}$ dose level were there differences. Intact rats given this dose intravenously responded with a pattern similar to that produced by the other two doses. Intraperitoneal injection of $0.001 \mu \mathrm{g}$ was followed by a rapid rise in agglutinin level from 4 to 6 days later. There was a subsequent slight gradual increase,

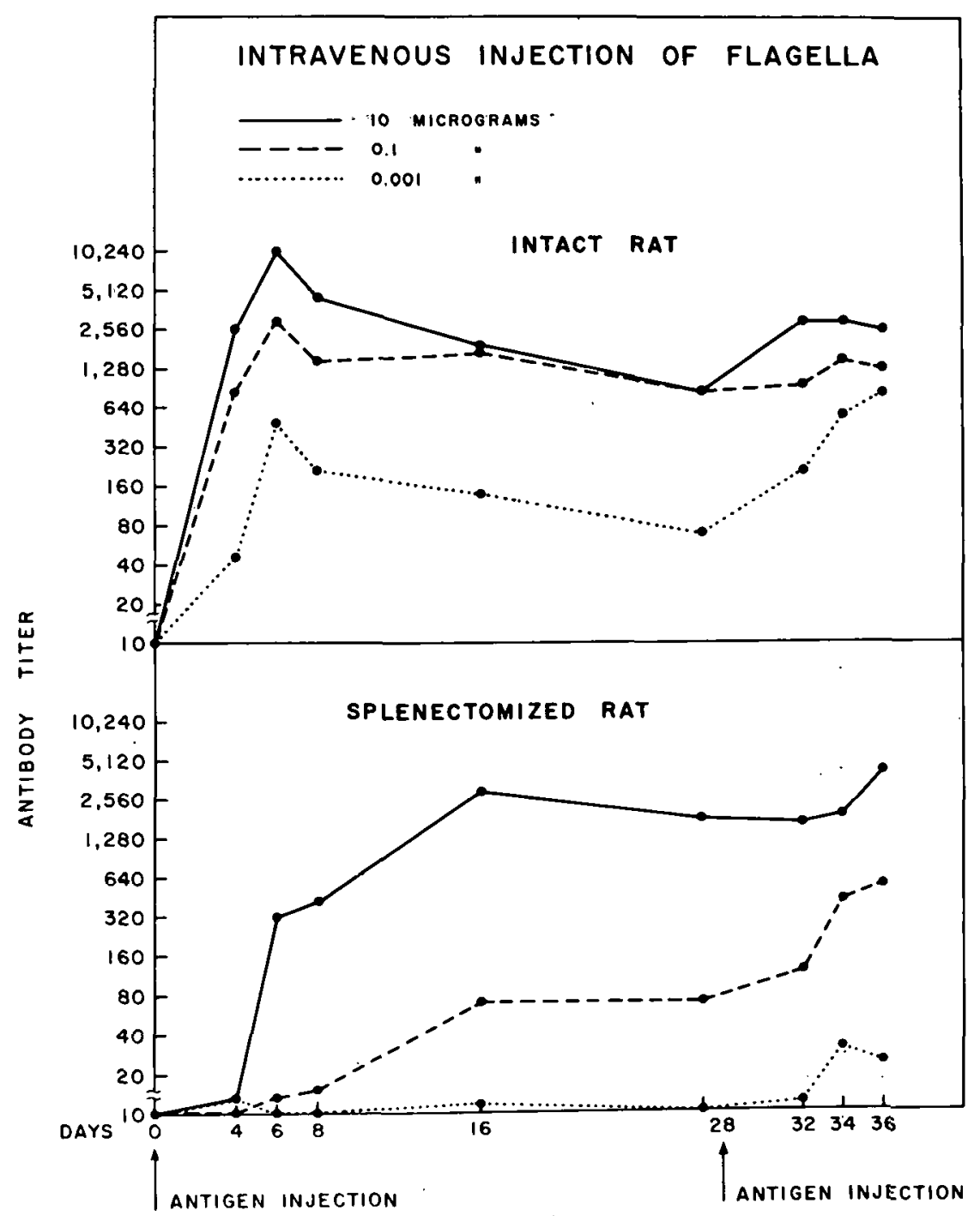

Figure 1. H-agglutinin response of intact and splenectomized rats after primary and secondary intravenous immunization with flagella from Salmonella typhosa. Each point is the geometric mean titer for a group of five animals. A titer of 10 was arbitrarily assigned to those rats whose sera did not agglutinate bacteria at the lowest dilution tested.

at a rate apparently unaltered by a second antigen injection. Subcutaneous injection of this lowest dose produced only a slight response evident on the 16th day after injection. Secondary subcutaneous stimulation was followed by a marked rapid rise.

In splenectomized rats, the general pattern of agglutinin response was similar for all groups. 
However, $0.001 \mu \mathrm{g}$ of flagella given subcutaneously provoked somewhat higher agglutinin titers after the 2nd injection than the same dose given intraperitoneally or intravenously. Furthermore the splenectomized rats given $0.001 \mu \mathrm{g}$ antigen intravenously consistently showed the most depression of antibody response.

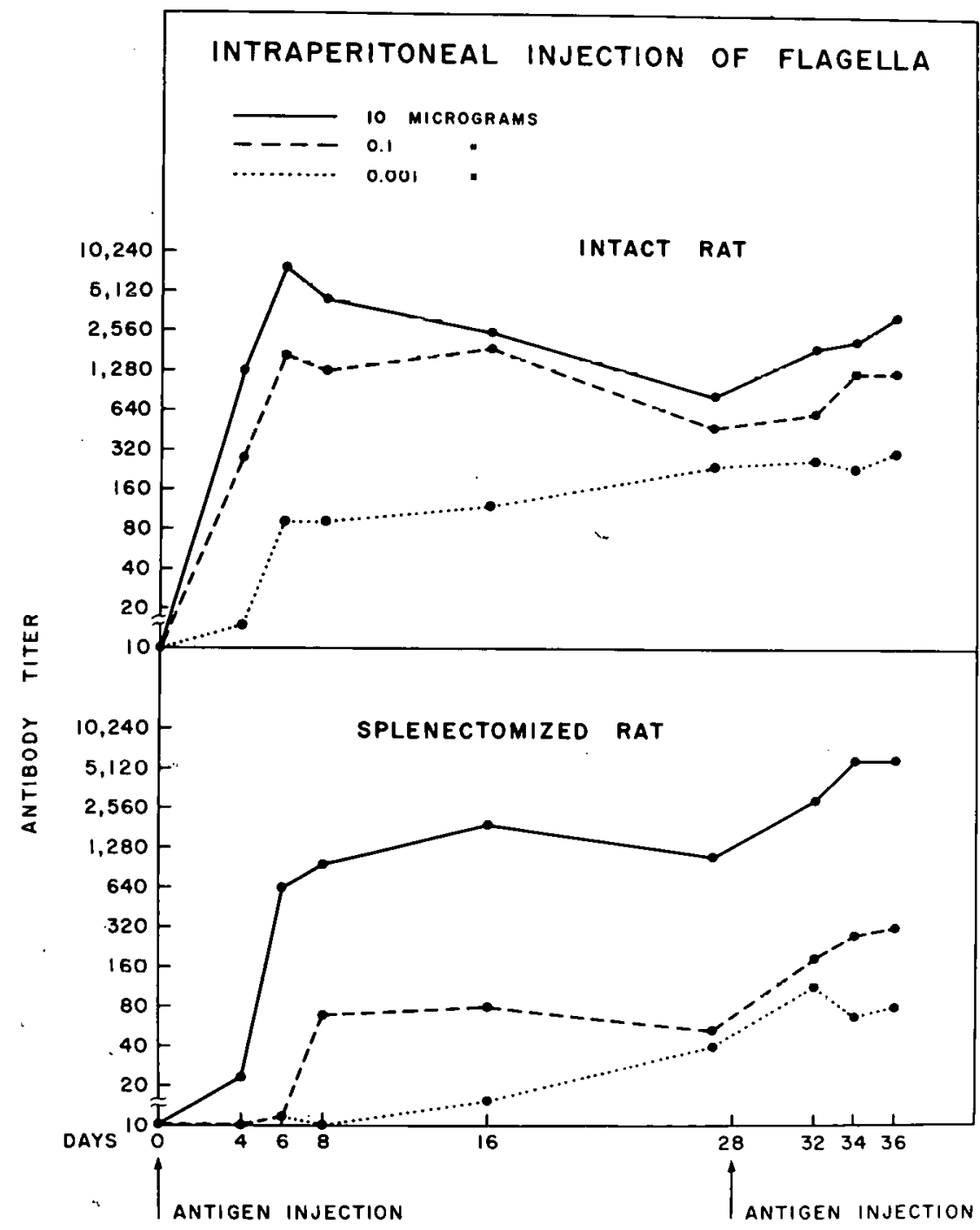

Figure 2. H-agglutinin response of intact and splenectomized rats after primary and secondary intraperitoneal immunization with flagella from Salmonella typhosa. Each point is the geometric mean titer for a group of five animals. A titer of 10 was arbitrarily assigned to those rats whose sera did not ag-. glutinate bacteria at the lowest dilution tested.

Increase in agglutinin levels after secondary stimulation was, in general, smaller for rats which had higher titers at the time of second antigen injection. Those rats which had more pronounced rise in agglutinin level after secondary stimulation were generally those which had rather low titers at the time of second injection. These observations were true for all groups. 
Statistical analysis showed that the effects of splenectomy interacted with those of dose of antigen and the route of administration. Consequently, the data for the intact and the splenectomized animals were analyzed separately. These data are summarized in Table 1. The agglutinin response of splenectomized rats clearly exhibits greater variation than that of intact animals. In the intact animals, injection of the larger doses of antigen by any route resulted in

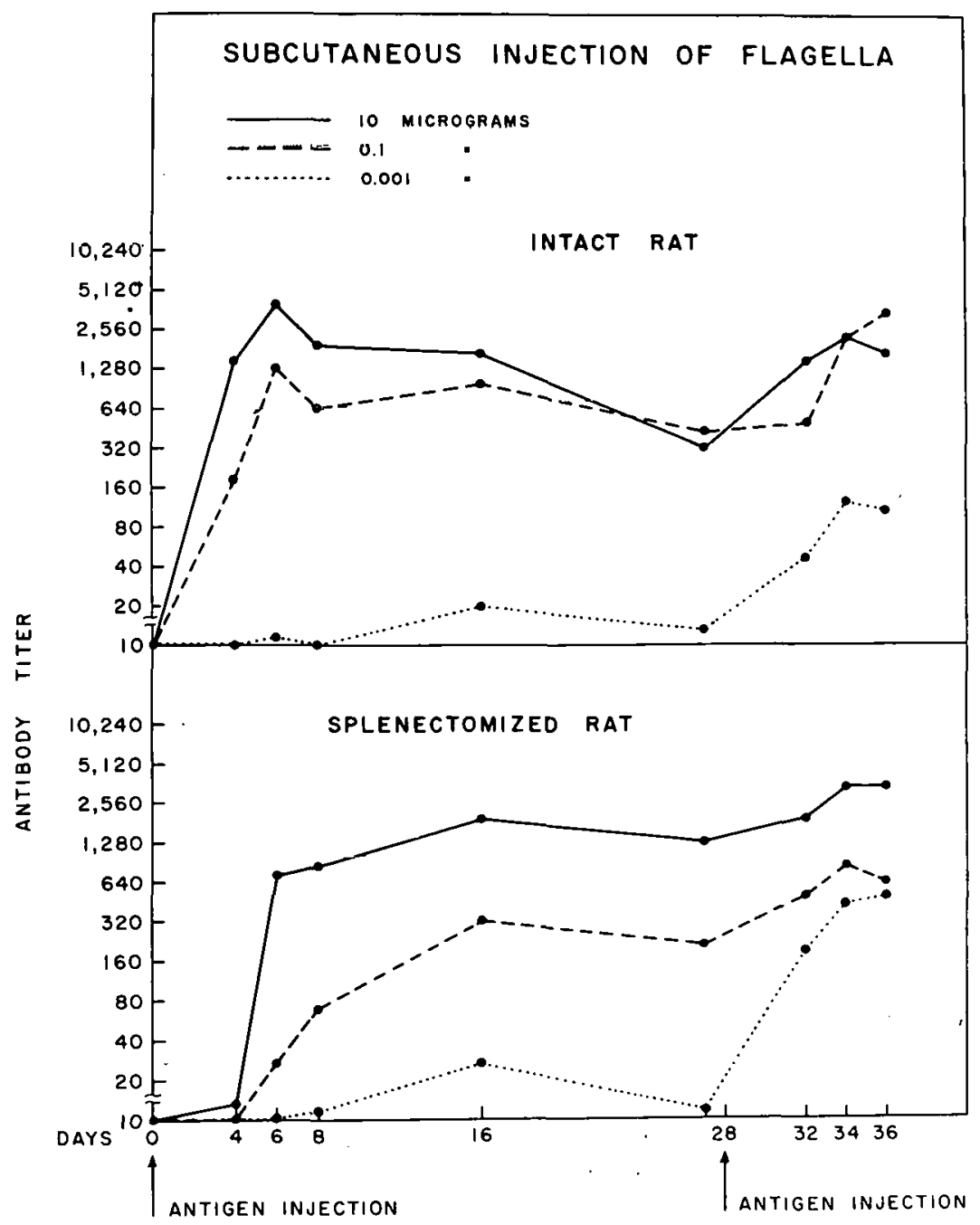

Figure 3. H-agglutinin response of intact and splenectomized rats after primary and secondary subcutaneous immunization with flagella from Salmonella typhosa. Each point is the geometric mean titer for a group of five animals. A titer of 10 was arbitrarily assigned to those rats whose sera did not agglutinate bacteria at the lowest dilution tested.

greater agglutinin response during the 4- to 8-day period following the initial immunization. The response also differed with the route of injection. The intravenous route gave the highest level of circulating antibody, the intraperitoneal route came next and the subcutaneous route was the lowest. In the 16- to 27-day post-injection interval neither the evidence for an effect of 
quantity of antigen for the doses tested nor the evidence for the effect of the route of injection was significant at the 5 per cent level. In splenectomized rats however the largest dose of antigen resulted in higher titers in both early and late phases of the primary response. The apparent differences due to route of antigen injection were not statistically significant. This may be due, in part, to the great variability of agglutinin response within each splenectomized group.

In the secondary response of the intact rat, the route of injection influenced the antibody response. The intravenous route was again the most effective; the subcutaneous route was less

Table 1

MEAN AGGLUTININ RESPONSE* FOR INTACT AND SPLENECTOMIZED RATS DURING THE "EARLY" AND "LATE PRIMARY" AND "SECONDARY" RESPONSE OF IMMUNIZATION WITH FLAGELLA OF S. TYPHOSA

\begin{tabular}{|c|c|c|c|c|}
\hline \multirow{3}{*}{ Route of injection } & \multirow{3}{*}{$\begin{array}{c}\text { Dose of } \\
\text { antigen }(\mu \mathrm{g})\end{array}$} & \multicolumn{3}{|c|}{ Days after antigen injection } \\
\hline & & \multicolumn{2}{|c|}{ Primiary response } & \multirow{2}{*}{$\frac{\text { Secondary response }}{4-8}$} \\
\hline & & $4-8$ & $16-27$ & \\
\hline \multicolumn{5}{|c|}{ Intact rats } \\
\hline Intraperitoneal & $\begin{array}{l}10.0 \\
0.1 \\
0.001\end{array}$ & $\begin{array}{r}8.75 \pm 0.26 \\
6.65 \pm 0.35 \\
x_{2} .55 \pm 1.14\end{array}$ & $\begin{array}{r}7.20 \pm 0.25 \\
6.60 \pm 0.68 \\
x_{4.10} \pm 1.18\end{array}$ & $\begin{array}{r}7.90 \pm 0.49 \\
6.75 \pm 0.44 \\
x_{4.75} \pm 1.37\end{array}$ \\
\hline Intravenous & $\begin{array}{l}10.0 \\
0.1 \\
0.001\end{array}$ & $\begin{array}{r}b_{9.25} \pm 0.25 \\
7.50 \pm 0.24 \\
x_{4.50} \pm 1.12\end{array}$ & $\begin{array}{r}b_{7.00} \pm 0.42 \\
6.90 \pm 0.19 \\
3.50 \pm 0.82\end{array}$ & $\begin{array}{r}b_{8.15} \pm 0.39 \\
7.00 \pm 0.19 \\
3.20 \pm 0.79\end{array}$ \\
\hline Subcutaneous & $\begin{array}{l}10.0 \\
0.1 \\
0.001\end{array}$ & $\begin{array}{r}8.00 \pm 0.14 \\
6.05 \pm 0.66 \\
x_{0.10} \pm 0.10\end{array}$ & $\begin{array}{r}6.20 \pm 0.20 \\
6.10 \pm 0.51 \\
\times 0.70 \pm 0.34\end{array}$ & $\begin{array}{l}7.55 \pm 0.44 \\
7.40 \pm 0.58 \\
3.20 \pm 0.79\end{array}$ \\
\hline \multicolumn{5}{|c|}{ Splenectomized rats } \\
\hline Intraperitoneal & $\begin{array}{l}10.0 \\
0.1 \\
0.001\end{array}$ & $\begin{array}{r}5.10 \pm 0.93 \\
x_{0.80} \pm 0.34 \\
b_{0.00} \pm 0.00\end{array}$ & $\begin{array}{r}7.50 \pm 0.48 \\
x_{2} .70 \pm 1.11 \\
x_{1} 1.67 \pm 0.56\end{array}$ & $\begin{array}{r}8.95 \pm 0.41 \\
4.70 \pm 1.18 \\
b_{4.00} \pm 0.99\end{array}$ \\
\hline Intravenous & $\begin{array}{l}10.0 \\
0.1 \\
0.001\end{array}$ & $\begin{array}{r}3.95 \pm 0.78 \\
x_{0.35} \pm 0.22 \\
x_{0.10} \pm 0.10\end{array}$ & $\begin{array}{l}a_{7.75} \pm 1.00 \\
x_{2.80} \pm 1.32 \\
x_{0.10} \pm 0.10\end{array}$ & $\begin{array}{r}\mathrm{a}_{8.37} \pm 0.42 \\
5.05 \pm 1.01 \\
\mathrm{x}_{1.15} \pm 0.53\end{array}$ \\
\hline Subcutaneous & $\begin{array}{l}10.0 \\
0.1 \\
0.001\end{array}$ & $\begin{array}{r}4.80 \pm 0.35 \\
x_{1.40} \pm 0.92 \\
x_{0.05} \pm 0.05\end{array}$ & $\begin{array}{r}7.30 \pm 0.60 \\
4.70 \pm 1.08 \\
x_{0.80} \pm 0.47\end{array}$ & $\begin{array}{l}8.20 \pm 0.36 \\
6.10 \pm 0.86 \\
5.15 \pm 0.84\end{array}$ \\
\hline
\end{tabular}

The results are expressed as the last tube number containing grossly visible agglutination. The mean tube number for each interval was calculated for each rat. Listed in the table are the mean tube number for 5 rats \pm the standard error of the mean. Groups indicated by (a) contained 4 rats; by (b), 3 rats. Groups indicated by $(x)$ contained animals where tube 0 was arbitrarily assigned when sera had no agglutination at the lowest dilution tested. The agglutinin titer can be calculated using the formula $10 \times 2^{n}$ where $n=$ tube number. 
so and the intraperitoneal route elicited the lowest response. The dose of antigen also affected the agglutinin level of the secondarily stimulated intact rat. This effect however, was paradoxical; the second injection of the $10 \mu \mathrm{g}$ dose of flagella in all instances was followed by a response lower than at a comparable period after the first injection. A second injection of the 0.1 $\mu \mathrm{g}$ dose given intraperitoneally or subcutaneously was followed by a higher response than at a comparable period after the first injection. The second injection of a $0.001 \mu \mathrm{g}$ dose of antigen by all routes led to a definite increase of antibody over the first injection.

In the secondary response of the splenectomized rat, the evidence for an effect of the route of injection or the dose of the antigen on the agglutinin response was not significant at the 5 per cent level for the two higher doses of flagella. However, rather marked differences were noted in levels when $0.001 \mu \mathrm{g}$ flagella was given by different routes. Subcutaneous injection of this dose resulted in the greatest response; intravenous injection, the lowest. It should be noted again however, that there was great variability in the response of splenectomized rats.

Since a small amount of carbohydrate material, possibly representing endotoxin, was present in the flagella preparation; antibody levels against the somatic antigens of S. typhosa were determined for selected sera.

Sera from both intact and splenectomized rats obtained 8 days after second injection of 10 $\mu \mathrm{g}$ flagella gave no agglutination of alcohol-killed S. typhosa $0-901$ organisms. ${ }^{*}$ However, when antibody levels were measured using sheep erythrocytes sensitized with alkali and heat-treated lipopolysaccharide from $\mathrm{S}$. typhosa $0-901$, antibody was detectable. The hemagglutination reaction gave a considerably more sensitive measure of antibody content.

Many of the pre-immunization sera had O-antibody titers as high as 160 using the hemagglutination reaction. There was an irregular $\mathrm{O}$-antibody response after immunization with $10 \mu \mathrm{g}$ flagella which was related neither to the pre-immunization O-antibody levels, nor to the $\mathrm{H}$-antibody response. Several rats receiving $10 \mu \mathrm{g}$ flagella gave no $\mathrm{O}$-antibody response. The highest O-antibody titers of 10240 were found in two rats after secondary stimulation with $10 \mu \mathrm{g}$ flagella. In intact rats, intravenous injection of $10 \mu \mathrm{g}$ flagella resulted in an average peak $\mathrm{O}$-antibody titer of 3280 . The same dose given intraperitoneally was followed by an average peak titer of 443 while subcutaneous injection resulted in an average peak titer of 113 . Splenectomized rats receiving $10 \mu \mathrm{g}$ flagella intravenously had average peak $\mathrm{O}$-antibody titers of only 30 ; when given the same dose intraperitoneally they responded with an average peak titer of 360 , and after.subcutaneous injection with an average peak titer of 28 . Since there appeared to be no correlation between the $\mathrm{H}$ - and $\mathrm{O}$-antibody response, determinations of $\mathrm{O}$-antibody levels after injection of the lower doses of flagella were not made.

Flagellin. The pattern of agglutinin response to flagellin is shown graphically in Figures 4-6. The general pattern is similar for all groups of animals. There was a rather slow, gradual increase in agglutinin titer reaching a peak at the 16 th or 27 th day after the first antigen injection. The difference in titer between these times was not great in any group. After the second injection of flagellin, there was an increase in titer to levels greater than those previously attained. The magnitude of the secondary response did not appear to be related to the agglutinin titer at the time of re-injection of antigen.

* Rat serum obtained 8 days after immunization with a suspension of S. typhosa 0-901 organisms had an agglutinin titer of 640 using the standard bacterial agglutinin reaction, but a hemagglutinin titer of 327,680 using sheep erythrocytes sensitized with the endotoxin. 
Intact rats receiving the largest dose of antigen by any route had an earlier rise in titer with a small peak on the 6th day after antigen injection; this early rise was not present in splenectomized animals. In addition, splenectomized rats receiving $0.001 \mu \mathrm{g}$ of flagellin intraperitoneally or intravenously had lower primary and secondary agglutinin responses than did intact rats. This was not true when this dose of antigen was administered subcutaneously.

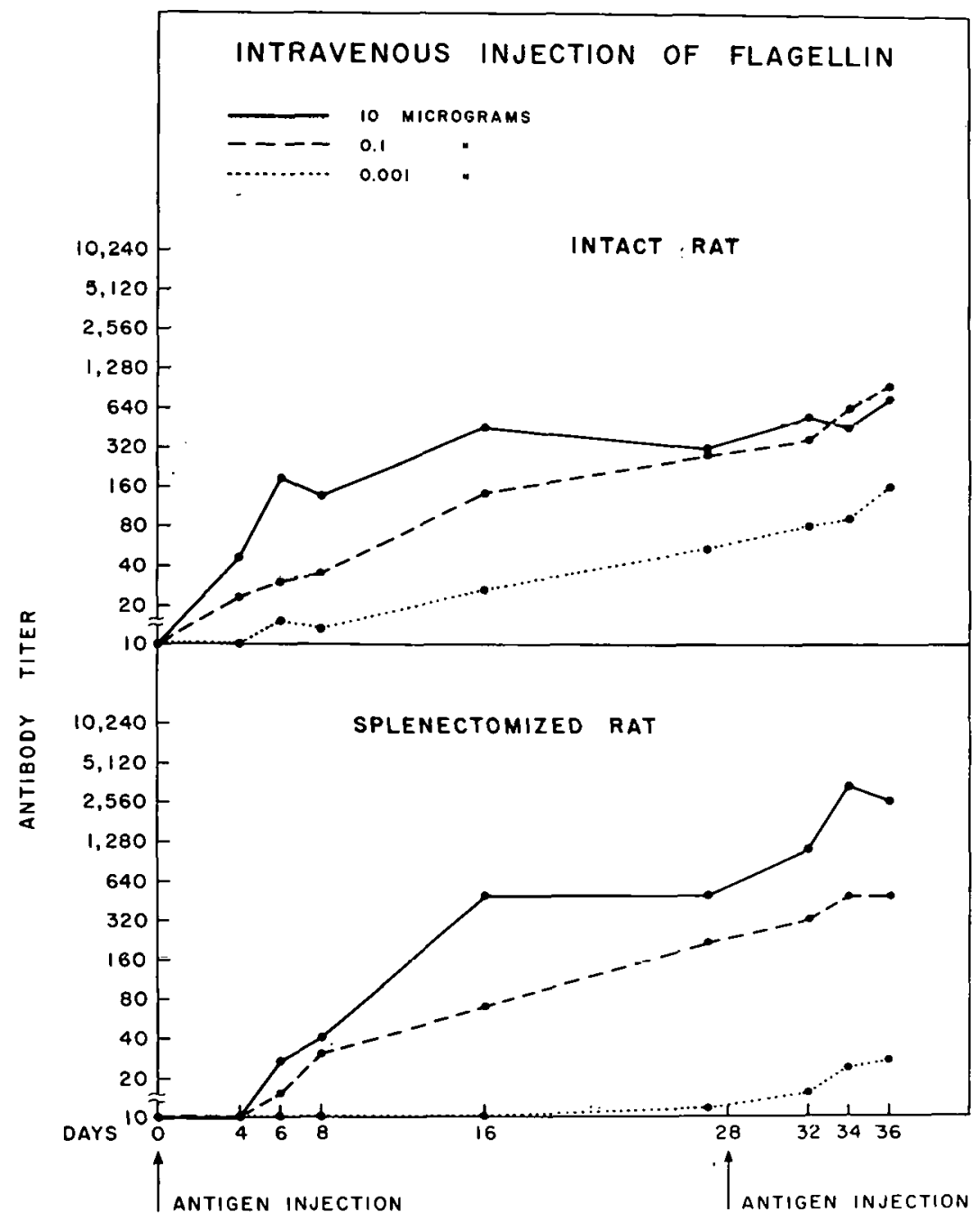

Figure 4. H-agglutinin response of intact and splenectomized rats after primary and secondary intravenous immunization with flagellin from Salmonella typhosa. Each point is the geometric mean titer for a group of five animals. A titer of 10 was arbitrarily assigned to those rats whose sera did not agglutinate bacteria at the lowest dilution tested.

The data, upon which the statistical analysis was based, are summarized in Table 2. As mentioned above, analysis showed that the effects of dose of antigen and the route of administration were different in intact and in splenectomized animals. For example, the increase in antibody response caused by an increase in dose of antigen was greater for intact than for splenectomized rats. 
In contrast to the results obtained after injection of flagella, the agglutinin response is generally more variable in the intact than in the splenectomized animal. In most groups of all rats, injection of the largest of tested doses of antigen by any route resulted in greater agglutinin response at each of the intervals analyzed. However, the evidence for an effect of quantity of antigen on the agglutinin titer was not significant in the secondary response of intact rats and in

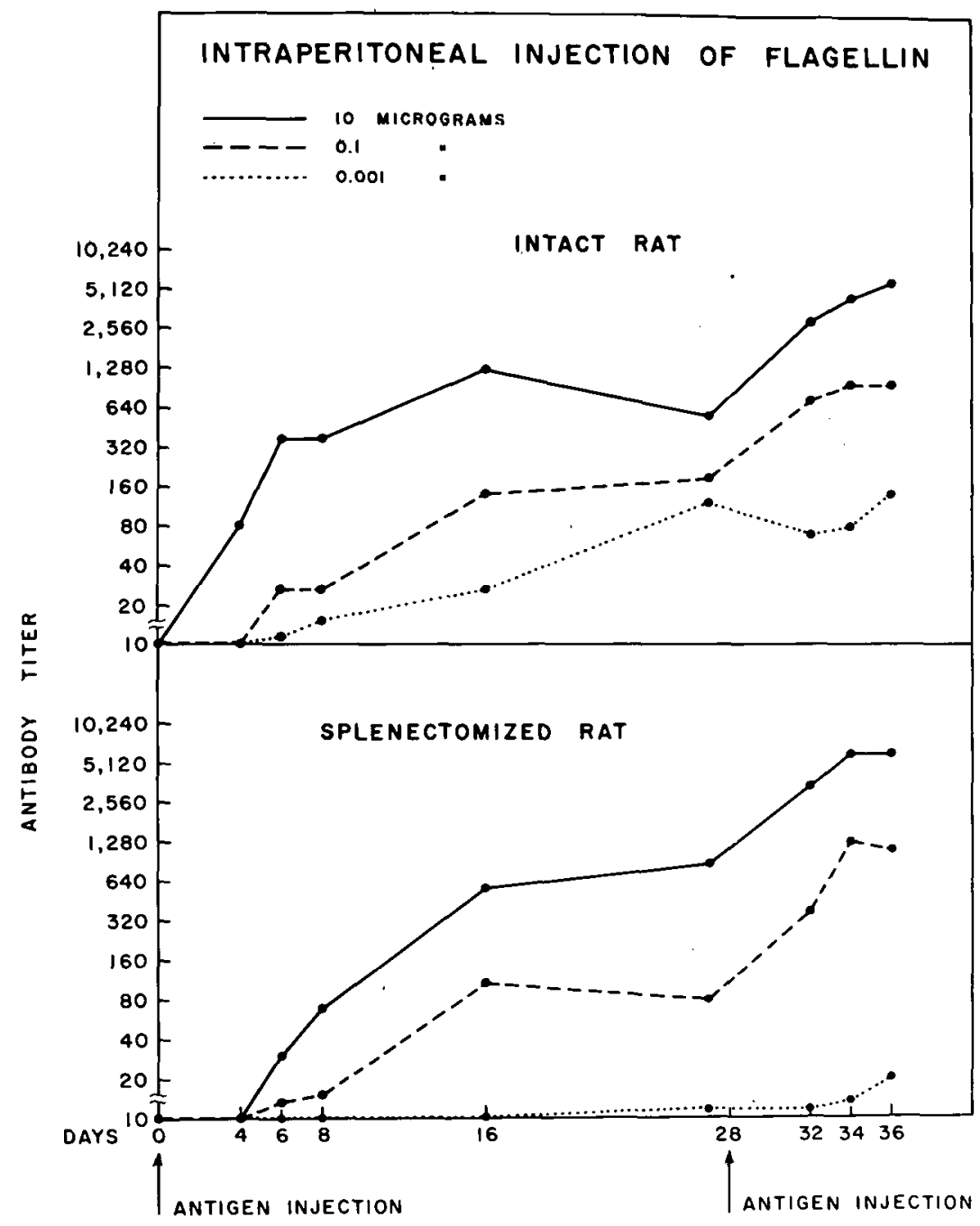

Figure 5. H-agglutinin response of intact and splenectomized rats after primary and secondary intraperitoneal immunization with flagellin from Salmonella typhosa. Each point is the geometric mean titer for a group of five animals. A titer of 10 was arbitrarily assigned to those rats whose sera did not agglutinate bacteria at the lowest dilution tested.

the early primary response of splenectomized rats. At the other time intervals similar evidence was significant at the 5 per cent level.

The evidence for the effect of the route of antigen injection was significant at the 5 per cent level only during the early primary response in intact rats. Results at the other intervals and 
in splenectomized rats at all intervals were not significant at the 5 per cent level. The intraperitoneal route was most effective, the intravenous route of injection less so, and the subcutaneous route was least effective.

Since a small amount of carbohydrate material possibly representing endotoxin was present in the flagellin preparation, antibody levels against the somatic antigens of $\mathrm{S}$. typhosa were

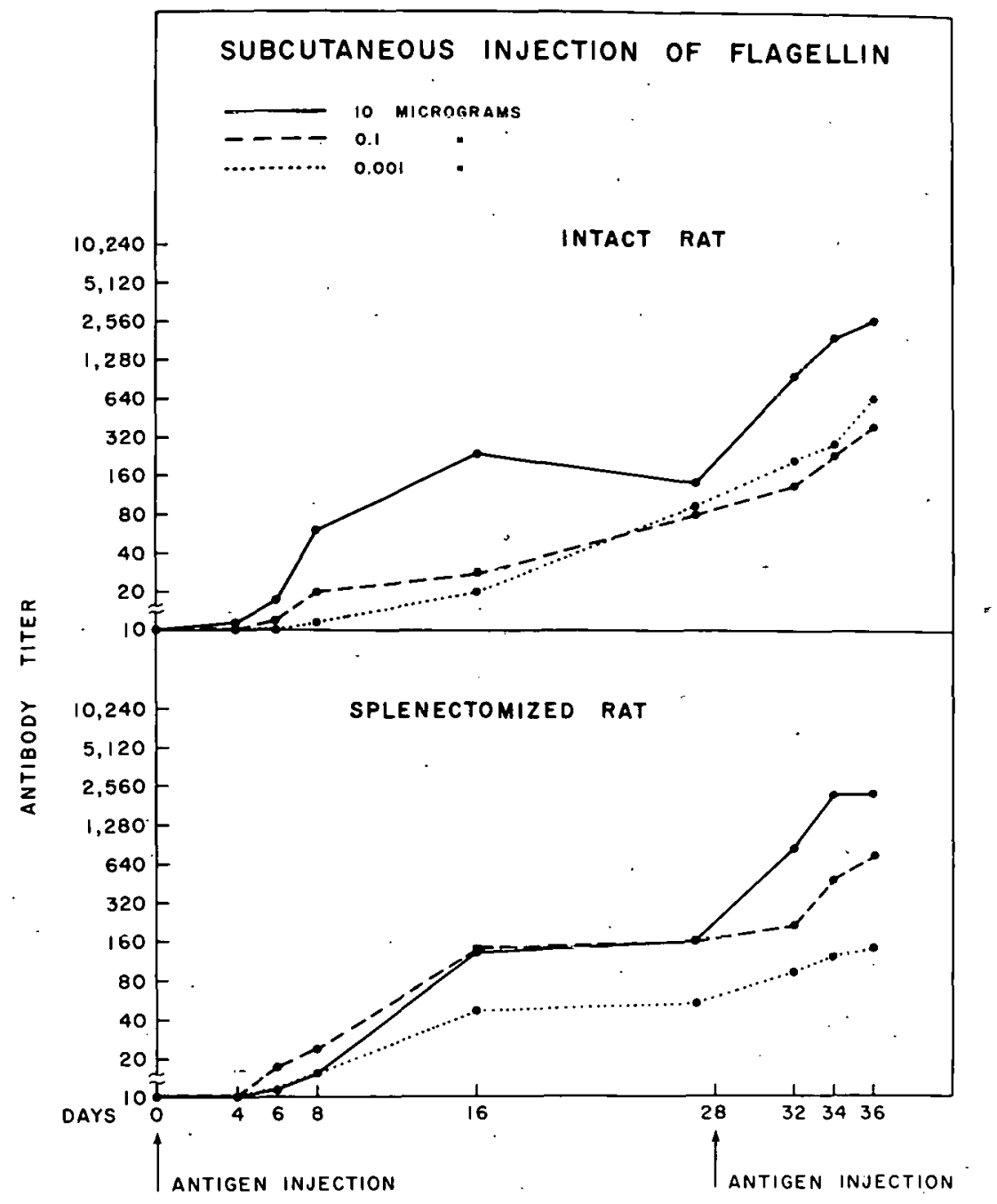

Figure 6. H-agglutinin response of intact and splenectomized rats after primary and secondary subcutaneous immunization with flagellin from Salmonella typhosa. Each point is the geometric mean titer for a group of five animals. A titer of 10 was arbitrarily assigned to those rats whose sera did not aggutinate bacteria at the lowest dilution tested.

determined for selected sera. Sera from both intact and splenectomized rats obtained 8 days after second injection of $10 \mu \mathrm{g}$ flagellin gave no.agglutination of alcohol-killed S. typhosa O-901 organisms. However, when antibody levels were measured using sheep erythrocytes sensitized with alkali and heat-treated lipopolysacchäride from $\underline{S}$. typhosa O-901, antibody was detectable. 
Table 2

MEAN AGGLUTININ RESPONSE* FOR INTACT AND SPLENECTOMIZED RATS DURING THE "EARLY" AND "LATE PRIMARY" AND "SECONDARY" RESPONSE OF IMMUNIZATION WITH FLAGELLIN OF S. TYPHOSA

\begin{tabular}{|c|c|c|c|c|}
\hline \multirow{3}{*}{ Route of injection } & \multirow{3}{*}{$\begin{array}{c}\text { Dose of } \\
\text { antigen }(\mu \mathrm{g})\end{array}$} & \multicolumn{3}{|c|}{ Days after antigen injection } \\
\hline & & \multicolumn{2}{|c|}{ Primary response } & \multirow{2}{*}{$\frac{\text { Secondary response }}{4-8}$} \\
\hline & & $4-8$ & $16-27$ & \\
\hline \multicolumn{5}{|c|}{ Intact rats } \\
\hline Intraperitoneal & $\begin{array}{l}10.0 \\
0.1 \\
0.001\end{array}$ & $\begin{array}{l}4.65 \pm 0.61 \\
b_{1} .05 \pm 0.87 \\
b_{0.25} \pm 0.24\end{array}$ & $\begin{array}{r}6.40 \pm 0.40 \\
b_{4.00 \pm 1.04} \\
b_{2.10} \pm 0.60\end{array}$ & $\begin{array}{r}8.75 \pm 0.35 \\
6.50 \pm 0.91 \\
b_{3.15} \pm 1.10\end{array}$ \\
\hline Intravenous & $\begin{array}{l}10.0 \\
0.1 \\
0.001\end{array}$ & $\begin{array}{r}a_{3.38} \pm 0.85 \\
b_{1.55} \pm 0.69 \\
a b_{0.06} \pm 0.06\end{array}$ & $\begin{array}{l}a_{5.12} \pm 0.66 \\
4.30 \pm 0.84 \\
b_{1.90} \pm 0.56\end{array}$ & $\begin{array}{l}5.75 \pm 0.32 \\
5.95 \pm 0.81 \\
3.35 \pm 0.69\end{array}$ \\
\hline Subcutaneous & $\begin{array}{l}10.0 \\
0.1 \\
0.001\end{array}$ & $\begin{array}{r}1.10 \pm 0.32 \\
\mathrm{ab}_{0.3 .8} \pm 0.22 \\
\mathrm{~b}_{0.05} \pm 0.04\end{array}$ & $\begin{array}{l}b_{4.20} \pm 1.35 \\
2.00 \pm 0.53 \\
2.10 \pm 0.68\end{array}$ & $\begin{array}{l}7.45 \pm 0.83 \\
4.70 \pm 0.61 \\
5.00 \pm 0.76\end{array}$ \\
\hline \multicolumn{5}{|c|}{ Splenectomized rats } \\
\hline Intraperitoneal & $\begin{array}{l}10.0 \\
0.1 \\
0.001\end{array}$ & $\begin{array}{l}1.50 \pm 0.40 \\
b_{0.35} \pm 0.28 \\
b_{0.00} \pm 0.00\end{array}$ & $\begin{array}{r}6.10 \pm 0.37 \\
b_{3.20} \pm 0.87 \\
b_{0.10} \pm 0.10\end{array}$ & $\begin{array}{r}9.00 \pm 0.49 \\
6.50 \pm 0.79 \\
b_{0.50} \pm 0.37\end{array}$ \\
\hline Intravenous & $\begin{array}{l}10.0 \\
0.1 \\
0.001\end{array}$ & $\begin{array}{l}b_{1.20} \pm 0.51 \\
b_{0.70} \pm 0.46 \\
b_{0.00 \pm 0.00}\end{array}$ & $\begin{array}{r}5.60 \pm 0.28 \\
3.60 \pm 0.87 \\
b_{0.10} \pm 0.10\end{array}$ & $\begin{array}{r}7.90 \pm 0.59 \\
5.45 \pm 0.93 \\
\mathrm{~b}_{1.10} \pm 1.0 .4\end{array}$ \\
\hline Subcutaneous & $\begin{array}{l}10.0 \\
0.1 \\
0.001\end{array}$ & $\begin{array}{l}b_{0.25} \pm 0.14 \\
b_{0.70} \pm 0.17 \\
b_{0.25} \pm 0.20\end{array}$ & $\begin{array}{l}\mathrm{a}_{3.62} \pm 0.82 \\
b_{3.90} \pm 0.99 \\
b_{2.30} \pm 1.15\end{array}$ & $\begin{array}{l}7.45 \pm 0.85 \\
5.45 \pm 0.99 \\
3.55 \pm 1.51\end{array}$ \\
\hline
\end{tabular}

The results are expressed as the last tube number containing grossly visible agglutination. The mean tube number for each interval was calculated for each rat. Listed in the table are the mean tube number for 5 rats \pm the standard error of the mean. Groups indicated by (a) contained 4 rats. Groups indicated by (b) contained animals where tube 0 was arbitrarily assigned when sera had no agglutination at the lowest dilution tested. The agglutinin titer can be calculated using the formula $10 \times 2^{n}$ where $n=$ tube number.

The hemagglutination reaction gave a considerably more sensitive measure of antibody content. ${ }^{\dagger}$

Occasional pre-immunization sera had O-antibody titers as high as 40 when tested with the hemagglutination reaction. There was a slight, irregular 0 -antibody response after immunization with $10 \mu \mathrm{g}$ flagellin which related neither to pre-immunization $\mathrm{O}$-antibody levels nor to, the

\footnotetext{
${ }^{\dagger}$ Rat serum obtained 8 days after immunization with a suspension of $\mathrm{S}$. typhosa organisms had an agglutinin titer of 640 using the standard bacterial reaction, but a hemagglutinin titer of 327,680 using sheep erythrocytes sensitized with the endotoxin.
} 
$\mathrm{H}$-antibody response. A maximum titer of 2,560 was rendered in one animal 4 days after second injection of $10 \mu \mathrm{g}$ flagellin. The serum levels of O-antibody were generally lower after immunization with flagellin than after flagella injections, although the amount of endotoxin administered must have been the same. It is not known whether or not endotoxin is attached to the flagellar antigen, and hence soluble when flagellin is administered and particulate when flagella are injected.

\section{DISCUSSION}

Different patterns of antibody response have traditionally been described for different classes of antigenic materials such as serum proteins, erythrocytes, bacterial polysaccharides and toxoids. Edsall points out however that such comparisons may not be entirely justified, since the experiments in question were performed by different workers under different conditions. ${ }^{10}$ The present study indicates that such experimental variables as the dose of antigen, the first or second response, and the route of immunization, may greatly influence the pattern of antibody response.

There appear to be several important differences between the immunological reactions of the rat and other commonly used laboratory animals. The rat develops an Arthus phenomenon only with difficulty. ${ }^{11}$ It demonstrates an unusual type of anaphylactic response and does not develop a tuberculin reaction. ${ }^{12}$ However, severe active cutaneous hypersensitivity to particulate or soluble antigens develops when rats are injected with a mixture of the antigen and pertussis vaccine. ${ }^{13}$ The rat produces precipitins in small quantities if at all. ${ }^{14}$ Although immune elimination of rabbit gamma globulin was demonstrated by Weigle and Dixon, no precipitating anti-rabbit gamma globulin was detectable after antigen elimination. ${ }^{15}$ Farr has presented evidence indicating that rat antibodies are able to combine with bovine serum albumin but have a low antigen-precipitating efficiency. ${ }^{16}$ The reasons for these immunological peculiarities of the rat are not evident.

The flagellar preparations used in this study are fairly pure, highly antigenic and virtually non-toxic. It is possible to vary the quantity of injected antigen at least 10,000 fold, a range not possible with most other antigens effective in the rat. Preliminary experiments tested intravenous injection of up to $1 \mathrm{mg}$ of this antigen, a quantity $10^{6}$ greater than the lowest effective dose used in these experiments. However, maximum agglutinin response was found after a single injection of $10 \mu \mathrm{g}$, and larger doses did not increase it. At lower doses, the level of circulating antibody titer was related to the quantity of antigen administered: smaller amounts of antigen resulting in a lower agglutinin response.

When particulate flagella was used, the apparent effect of the route of antigen injection on the agglutinin response was interrelated with the effect of dose of antigen administered. At the higher dose levels however, regardless of route of administration, the general pattern of response was similar although quantitatively different. Using smaller quantities of antigen, qualitative differences in response due to route become apparent. It is possible to select doses of flagella and routes of injection to produce patterns of response usually associated with other antigens. For example, $0.001 \mu \mathrm{g}$ injected subcutaneously results in a "toxoid" type of response with little or no antibody formed after the first antigen injection but rapid formation of antibody after the second antigen injection given one month later.

A paradoxical effect of antigen dose was noted in the secondary response of the intact ani- 
mal. After secondary stimulation with the larger antigen doses rats attained lower agglutinin levels than in the primary response while animals receiving smaller quantities of antigen had a secondary response greater than after the first antigen injection. Those groups with lower secondary responses generally had rather high levels at the time of the second immunization. Several studies have indicated that active antibody synthesis can be suppressed by administration of homologous or heterologous antibody before immunization. ${ }^{17,18}$ In some situations the degree of suppression is related both to dose of antigen and to dose of antibody. ${ }^{18}$ The high agglutinin levels existing in some groups of rats at the time of re-immunization probably had such a suppressing effect on the subsequent secondary response of these groups, thus influencing markedly the pattern of response. A more marked secondary response might be seen if the interval between primary and secondary stimulus were extended. However, the agglutinin titer was as high five months after primary antigen injection as it was at one month. ${ }^{19}$

All rats which had even a moderate agglutinin response to flagella maintained rather high antibody levels four weeks after the first antigen injection. The prolonged response is unusual after a single injection of a protein antigen and is usually associated with a secondary response. ${ }^{17}$ However, Richter and Haurowitz have shown that formation of antibodies to several protein antigens including bovine serum albumin and ovalbumin may continue in the rabbit for several months if sufficiently sensitive methods, such as agglutination of antigen-coated erythrocytes, are used for its detection. ${ }^{20}$ Evidence that the formation of agglutinins after the first antigenic stimulation with $\underline{\mathrm{S}}$. typhosa flagella is indeed a primary response is furnished by the observation that the response after a single injection of flagella is radiosensitive while the response after the second immunization with this antigen is not. ${ }^{21}$

Although some rats had low levels of $\mathrm{O}$-antibody in the pre-immunization serum sample, this is not necessarily indicative of a previous antigenic stimulation with the antigens of $\underline{S}$. typhosa since it is possible that they received $O$-antigenic stimulation previously from other sources. Somatic antigens IX and XII are widely shared with other Salmonella serotypes and even with other groups of organisms including Proteus and Escherichia. Furthermore, the response to the flagellar antigen bore no consistent relationship to the response to the somatic antigenic contaminant.

In addition to the influence of the dose of antigen and the route of its administration, the presence or absence of the spleen also had a marked effect on the pattern of antibody response to flagella when compared with intact animals. Splenectomized rats responded with lower peak titers and a delay in attaining the peak titer, regardless of the route of injection. Rowley reported that the inhibitory effect of splenectomy on circulating hemolysin levels in the rat was found only after intravenous injection of antigen. Intradermal, subcutaneous, intraperitoneal, and intraportal injection of antigen in splenectomized rats resulted in a response comparable to that of an intact rat. ${ }^{22}$

Taliaferro, on the other hand, noted that only the early phase of the hemolysin response to sheep erythrocytes was affected by splenectomy in the rabbit. ${ }^{23}$ The present study emphasizes that the nature of the antigen as well as the species of animal must be considered in evaluating the effect of splenectomy on the immune response.

Flagellar proteins offer a unique system for investigating the role of the physical state of the antigen on the immune response, since no foreign material is necessary to make the antigen insoluble. The normally particulate flagella can be made soluble in several ways. ${ }^{24}$ 
Antibody response after administration of purified soluble flagellar protein (flagellin) from Salmonella typhosa was measured in these experiments by determining the $\mathrm{H}$ agglutinin titer against the whole organism. It is likely that this method did not measure all the antibody produced. Studies by Read ${ }^{25}$ and by Koffler ${ }^{24}$ suggest that antigenic determinants masked in the whole flagella are uncovered when this material is solubilized by treatment with acid or heat. This same phenomenon has been observed with other antigens. ${ }^{26}$ However, agglutination of the whole organism appears to be a valid measure of at least one kind of antibody response since the precipitin reactions between flagella and antiserum directed against heat-dissociated flagella are similar to those between flagella and antiserum directed against intact flagella. 24

Dissociation of whole flagella by acid treatment can result in formation of monomers of flagellin having a molecular weight of about 20,000 in solutions below pH 3.8 , but this is true only under salt-free conditions. ${ }^{4}$ Suspensions of flagellin in saline solutions at neutral pH contain aggregates of flagellin molecules. There is some evidence to suggest that these may "bind" to various proteins present in the suspension. ${ }^{6}$ However, the size of these aggregates must be several orders of magnitude smaller than the size of intact flagella which measure about 20 to 50 millimicra in diameter and up to several micra in length.

Several differences were readily apparent when the agglutinin responses of the rat to the two forms of antigen were compared. In the case of flagellin the rise to peak titer was slower; only occasionally was there any suggestion of an early peak 6 days after antigen injection. The effect of splenectomy on agglutinin response was less marked; a second injection was followed by a rise in titer to levels above that attained after the primary injection. However, the titer 8 days after secondary antigen injection was not appreciably different for the two groups.

There are several possible explanations for these differences in antibody response. The difference in physical state may give rise to differences in distribution of the antigen among the various antibody-forming organs. Evidence has been presented indicating that concentration of antigen significantly influences the antibody response. ${ }^{27}$ It is also possible that flagella and flagellin may be handled differently by cells in antibody-forming organs. No evidence is available regarding the cellular metabolism of the flagellar antigens. Presumably flagella must be phagocytosed, and probably must be at least partially degraded before antibody formation can take place. Whether flagellin is handled similarly or whether its molecules can enter nonphagocytic cells by pinocytosis is not clear.

The spleen appears to play less of a role in the agglutinin response to soluble flagellin than to particulate flagella. Compared with intact rats splenectomized rats had lower agglutinin titers during the early primary response if flagellin was given intravenously or intraperitoneally but this effect was not as marked as when flagella was used. This again may be due to differences in organ distribution of antigen.

It is of interest that in those groups where the spleen appeared to play a major role in the immune response $(0.001 \mu \mathrm{g}$ flagellin given intravenously or intraperitoneally) the agglutinin titer reached a maximum 27 days after antigen injection. This is in contrast with those situations after injection of flagella where the agglutinin titer apparently due to splenic formation reached a peak 6 days after administration of antigen. The spleen may influence the immune response in several ways. The rat spleen can manufacture antibody, ${ }^{28}$ but it is possible that cells in the spleen may take up antigen, modify it, and release it to stimulate other antibody-forming sites. Cells in the spleen also may be modified by contact with antigenic material and then be released 
into the circulation to lodge in other sites to produce antibody there. Splenectomy as soon as 1 hour after injection of $0.001 \mu \mathrm{g}$ flagella does not prevent a secondary response when this dose of antigen is again administered 4 weeks later, although splenectomy before primary injection does so. ${ }^{21}$ These observations suggest that one or both of the latter possibilities may help explain the late rise in titer noted after injection of $0.001 \mu \mathrm{g}$ flagellin intravenously or intraperitoneally.

\section{LITERATURE CITED}

1. McMaster, P. O. In The Nature and Significance of the Antibody Response, ed. by A. M. Pappenheimer, New York: Columbia University Press, 1953, p. 13.

2. Edsall, G. In The Nature and Significance of the Antibody Response, ed. by A. M. Pappenheimer, New York: Columbia University Press, 1953, p. 69.

3. Stavitsky, A. Adv. Immunol., 1:211, 1961.

4. Kobayashi, T., T. N. Rinker, and H. Koffler. Arch. Biochem. Biophys., 84:342, 1959.

5. Scott, T. A., and E. H. Melvin. Anal. Chem., 25:1956, 1953.

6. Weinstein, D. The Occurrence of Flagellin Within the Cytoplasm of Penicillin-Induced Spheroplasts of Proteus vulgaris, Ph.D. Thesis, Purdue University, June, 1959.

7. Landy, M., A. G. Johnson, M. E. Webster, and J. Sagis. J. Immunol., 74:466, 1955.

8. Landy, M., R. Trapani, and W. R. Clark. Am. J. Hygiene, 62:54, 1955.

9. Neter, E., O. Westphol, O. Lüderitz,'E. A. Gerzynshi, and E. Eichenberger. J. Immunol., $76: 377,1956$.

10. Edsall, G. Ann. Rev. Microbiol., 9:347, 1955.

11. Kenton, H. B. J. Infect. Dis., 69:238, 1941.

12. Rich, A. R. The Pathogenesis of Tuberculosis, 2nd ed., Springfield, Ill., Charles C. Thomas, 1951 .

13. Rowley, D. A., J. Chutkow, and C. Attig. J. Exptl. Med., 110:751, 1959.

14. Molomut, N. J. Immunol., 37:113, 1939.

15. Weigle, W. O., and F. J. Dixon. J. Immunol., 79:24, 1957.

16. Farr, R. S. J. Infect. Dis., 103:239, 1958.

17. Uhr, J. W., and J. B. Baumann. 'J. Exptl. Med., 113:935, 1961.

18. Neiders, M. E., D. A. Rowley, and F. W. Fitch. J. Immunol., 88:718, 1962.

19. Fitch, F. W. 1961. Unpublished observations.

20. Richter, M., and F. Haurowitz. J. Immunol., 84:420, 1960.

21. Fitch, F. W., and J. W. Winebright. 1961. Unpublished observations.

22. Rowley, D. A. J. Immunol., 64:289, 1950.

23. Taliaferro, W. H., and L. G. Taliaferro. J. Infect. Dis., 87:37, 1950.

24. Koffler, H. Bact. Rev., 21:227, 1957. 
25. Read, K. S. Antigenic Properties of Bacterial Flagella, Ph.D. Thesis, Purdue University, June, 1957.

26. Bartel, A. H., and O. H. Campbell. Arch. Biophys. and Biochem., 82:232, 1959.

27. Farr, R. S., and F. J. Dixon. J. Immunol., 85:250, 1960.

28. Lavia, M. F., S. A. Uriu, and A. E. Warren. Arch. Pathol., 71:28, 1961. 


\title{
COMBINED INHIBITORY EFFECT OF ANTITUMOR ANTIBODY AND AN ONCOLYTIC VIRUS ON THE SOLID EHRLICH TUMOR ${ }^{\text {T }}$
}

By

\author{
M. J. Stone, K. Dzoga and R. W. Wissler
}

Recent studies have demonstrated the tumor-inhibiting properties of heterologous antisera made against the Ehrlich ascites tumor, ${ }^{1-5}$ and that the addition of complement enhances the cytotoxic effect. ${ }^{1-4}$ The presence of an ascitic tumor in the peritoneal cavity provides a means of easy access whereby intraperitoneally injected antibody may reach the tumor cells in vivo. However, attempts at selective localization of intravenously injected antibody in solid tumors have been largely unsuccessful possibly because of the relatively poor permeability of the capillary bed of the tumor to the large globulin molecules. ${ }^{1,2}$ Thus circulating tumor antibody, even though potentially cytotoxic and fairly specific, would have little therapeutic effect.

One way of altering the tumor vascular bed prior to the administration of antitumor antibodies is by means of oncolytic viruses, ${ }^{2}$ and there are neurotropic viruses which exhibit various degrees of oncolytic capacity for transplantable mouse tumors. ${ }^{7-9}$ These viruses have also been employed as anti-neoplastic agents for clinical trials in patients with advanced cancer. ${ }^{10,11}$ Unfortunately the patients rapidly became immune to the virus, so that only a transient oncolytic effect could be obtained.

As far as we know, this paper constitutes the first report on the effect of an oncolytic virus used in combination with antitumor antibodies on a solid tumor. The virus employed was Egypt 101 -the one which has proven most successful in clinical trials.

\section{MATERIALS AND METHODS}

Tumors. CF No. 1 mice, about $25 \mathrm{~g}$ in weight, were injected subcutaneously with $0.2 \mathrm{ml}$ of 5-7 day old Ehrlich ascites tumor.

Production of antitumor serum. The antiserum was produced by injecting normal adult rabbits with a washed suspension of ascites tumor cells using multiple portals for 3 weeks. ${ }^{1}$ It was collected by withdrawing blood from the immunized rabbits by cardiac puncture at the 4th, 5 th and 6 th weeks. The pooled sera were frozen and stored until ready for use. The $\gamma$-globulin fraction was separated by the alcoholic fractionation method of Nichol and Deutsch, ${ }^{6}$ lyophilized, and stored under refrigeration. Prior to injection, the anti-Ehrlich ascites (AEA) $\gamma$-globulin was tested for specificity by means of agglutination tests, and, when the antibody was labeled with $\mathrm{I}^{131}$, by in vitro combination of the antitumor $\gamma$-globulin with whole lyophilized tumor and other mouse organs. 1

Virus. Egypt 101 virus, in the form of a 20 per cent suspension of infected mouse brain in a mixture of rabbit serum and saline, was kindly supplied by Dr. Alice E. Moore. ${ }^{\ddagger}$ The virus was titered in 8-10 week old CF No. 1 mice by intracerebral inoculation of $0.03 \mathrm{ml}$ of serial 10fold dilutions of the virus-brain suspension. Various passages titered between $10^{-4}$ and $10^{-7}$. 10 (apor.

*This report is taken from a paper appearing in Laboratory Invest., 11:306/1962)

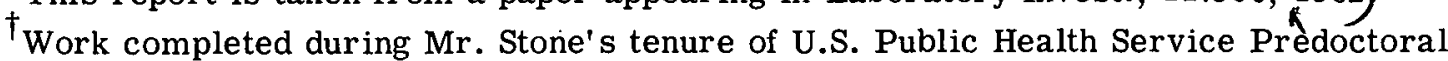
Traineeship, in the Department of Pathology, University of Chicago.

${ }^{\ddagger}$ Sloan-Kettering Institute, New York City, New York. 
Tumor-bearing mice were given intraperitoneal injections of $0.1 \mathrm{ml}$ of a 1:10, 1:40 or 1:60 dilution of the virus.

In vivo experiments. Six experiments were performed. The tumors were allowed to grow subcutaneously for 5-10 days, depending on the experiment. They were then measured and the mice were randomized into 4 groups bearing tumors of comparable size, only mice with definitely established tumors being used. The 4 groups were designated (O-O), no treatment; (G-O), AEA $\gamma$-globulin alone; $(\mathrm{V}-\mathrm{O})$, Egypt 101 virus alone; and $(\mathrm{G}-\mathrm{V})$, globulin-virus combination. The $(\mathrm{V}-\mathrm{O})$ and $(\mathrm{G}-\mathrm{V})$ groups received an $0.1 \mathrm{ml}$ intraperitoneal injection of the virus suspension. In the first two experiments, an identical amount of normal mouse brain was administered to the $(\mathrm{O}-\mathrm{O})$ and $(\mathrm{G}-\mathrm{O})$ groups as a control. In subsequent experiments, this control group was omitted because it was found that the normal brain suspension had no significant effect upon tumor growth.

On the fourth or fifth day after injection of the virus, the (G-O) and (G-V) groups were given intravenous injections of AEA $\gamma$-globulin. This schedule was adopted because it was assumed that the maximum oncolytic effect might be achieved 3-6 days after the virus was administered and before immunity to the virus developed. The dose of $\gamma$-globulin varied from 1.5 to $4.5 \mathrm{mg}$ in the different experiments. In experiments III and IV a second dose of the antibody was given 48 hours after the first. In experiment $\mathrm{V}$, normal rabbit $\gamma$-globulin was administered to 5 mice in each of the (O-O) and ( $\mathrm{V}-\mathrm{O})$ groups: no inhibitory effect on tumor growth was noted. The AEA $\gamma$-globulin was labeled with tracer amounts of $I^{131}$ in experiments $I$, II, and V. More extensive experiments involving $\mathrm{I}^{131}$-labeled antibodies will be reported at a later date.

In all experiments, the mice were autopsied 1,4 , or 5 days following the $y$-globulin injections. In experiment I all the animals were killed after 24 hours, in experiment III after 5 days. In experiments II, IV, and V, one-half the animals were killed at 24 hours: the other half at 5 days. In experiment VI the intervals were 24 hours and 4 days following the $\gamma$-globulin injections. At autopsy, the mice were weighed, tumors were measured and weighed, and samples were taken for histological study. Samples of other organs, such as liver, kidney and spleen, were also taken if these organs appeared remarkable grossly.

\section{RESULTS}

Tumor weights. The primary criterion used in judging the results was the average tumor weight in each of the 4 groups. Table 1 lists the mean tumor weights of each treatment group in each experiment. In 4 of the 6 experiments, the mice were studied at two different intervals after the $\gamma$-globulin injections so that there were essentially ten separate but similar weight measurements. In 9 of these 10 measurements, the lowest average tumor weight occurred in the (G-V) group, i.e., the group receiving both AEA $\gamma$-globulin and Egypt 101 virus (Figure 1). The only exception was the 5-day interval in experiment $V$, in which no effect was noted.

It is apparent from Table $I$ that an equal number of mice in each group did not usually survive to the end of an experiment. This may be attributed to two factors. First, some mice did not tolerate the intravenous injections of AEA $\gamma$-globulin well, especially when repeated injections were given (experiments III and IV). Since the dosage was $1 \mathrm{ml} /$ animal in the earlier experiments, this may have been partly due to hypervolemia. Later, the dosage was reduced to $0.5 \mathrm{ml} /$ animal. Also, as previously pointed out, the toxicity of intraperitoneally injected antibody varies inversely with the amount of tumor growing in the mouse. ${ }^{1}$ If this is also true for 
intravenously injected antibody, then it would tend to remove from the experiments animals with smaller tumors in the (G-O) and (G-V) groups. The mean tumor weights in these groups might have been smaller if all animals had survived. Nevertheless, the average tumor weights of the remaining animals in the (G-V) group were appreciably below those from the other three groups.

A second factor resulting in groups of unequal size at the end of an experiment was growth of the tumor. Especially in the mice which lived for 5 days after the $\gamma$-globulin injections, some tumors infiltrated the body wall into the peritoneal cavity. These animals then developed an ascites tumor in addition to their subcutaneous tumor, and some died before the end of the experiment.

Table 1

MEAN TUMOR WEIGHT (IN g) OF EACH TREATMENT GROUP IN EACH EXPERIMENT

\begin{tabular}{l|c|c|c|c|c|c|c|c|c}
\hline Exp. & $\begin{array}{c}\text { Day } \\
\text { of } \\
\text { death }\end{array}$ & $\begin{array}{c}\text { No. } \\
\text { of } \\
\text { mice }\end{array}$ & $\begin{array}{c}\text { Treatment } \\
\text { group } \\
\text { G-V }\end{array}$ & $\begin{array}{c}\text { No. } \\
\text { of } \\
\text { mice }\end{array}$ & $\begin{array}{c}\text { Treatment } \\
\text { group } \\
\text { G-O }\end{array}$ & $\begin{array}{c}\text { No. } \\
\text { of } \\
\text { mice }\end{array}$ & $\begin{array}{c}\text { Treatment } \\
\text { group } \\
\text { V-O }\end{array}$ & $\begin{array}{c}\text { No. } \\
\text { of } \\
\text { mice }\end{array}$ & $\begin{array}{c}\text { Treatment } \\
\text { group } \\
\text { O-O }\end{array}$ \\
\hline I & 1 & 3 & 0.150 & 4 & $(0.230) *$ & 5 & 0.403 & 4 & $(0.433)^{*}$ \\
II & 1 & 5 & 0.228 & 4 & $(0.742)$ & 4 & 0.290 & 5 & $(0.520)$ \\
III & 5 & 2 & 0.318 & 3 & $(1.991)$ & 3 & 1.401 & 3 & $(0.583)$ \\
IV & 5 & 3 & 0.598 & 4 & 0.781 & 4 & 0.653 & 4 & 1.788 \\
& 1 & 6 & 1.249 & 5 & 2.788 & 5 & 2.007 & 6 & 1.562 \\
V & 5 & 6 & 1.088 & 4 & 3.225 & 5 & 2.500 & 5 & 2.442 \\
& 5 & 6 & 0.337 & 7 & 0.400 & 7 & 0.434 & 7 & 0.535 \\
VI & 1 & 9 & 1.340 & 11 & 1.037 & 13 & 1.258 & 10 & 1.007 \\
& 4 & 7 & 0.772 & 9 & 1.084 & 9 & 1.051 & 9 & 1.069 \\
Total & & 56 & 6.82 & 59 & 13.77 & 62 & 11.18 & 59 & 11.82 \\
Mean & & & 0.682 & & 1.377 & & 1.118 & & 1.182 \\
\hline \multirow{2}{*}{$*$}
\end{tabular}
ments I and II.

Underlined figures indicate animals fasted for first three days of experiment, allowed food the last day.

Histopathology. In general, necrosis was more widespread in tumors from the (G-V) group. Infection with Egypt 101 virus is not characterized by the production of inclusion bodies and no viral-specific effect was identifiable with light microscopy. Focal necroses and non-specific inflammation were noted in the livers of some of the $\gamma$-globulin-treated animals.

Fasting of mice. In experiment VI, the mice to be killed 24 hours following the $\gamma$-globulin injections were fasted after injection. The average tumor weight of the (G-V) group was well below that of the other 3 groups (Table 1). The mice to be killed 4 days after the administration of the antibody were fasted for 3 days, then fed ad libitum for the last day. Food intake was similar 
in all groups. The lowest average tumor weight again occurred in the (G-V) group.

There appears to be little doubt that combined therapy involving Egypt 101 virus and AEA $\gamma$-globulin exerts an inhibitory effect on the growth of the solid form of the Ehrlich ascites tumor. When the data in Table 1 were subjected to an analysis of variance of logarithms using a conservative multiple comparison procedure such that the risk of any error in comparison among these means is 5 per cent, ${ }^{12}$ it was found that there was a statistically significant difference between the $(\mathrm{G}-\mathrm{V})$ group and each of the other 3 groups. The $(\mathrm{G}-\mathrm{O}),(\mathrm{V}-\mathrm{O})$ and $(\mathrm{O}-\mathrm{O})$ groups did not differ significantly from each other at the 5 per cent level. It is apparent that inhibition of tumor growth is due to an interaction of the antibody and virus and not to an additive mechanism, since neither exerts a significant effect alone. This would be expected if the virus were exerting a transient oncolytic effect which aided the entry of antibody into the tumor. Thus these experiments lend indirect support to the original postulate accounting for the failure of circulating antibody to localize in solid tumors.

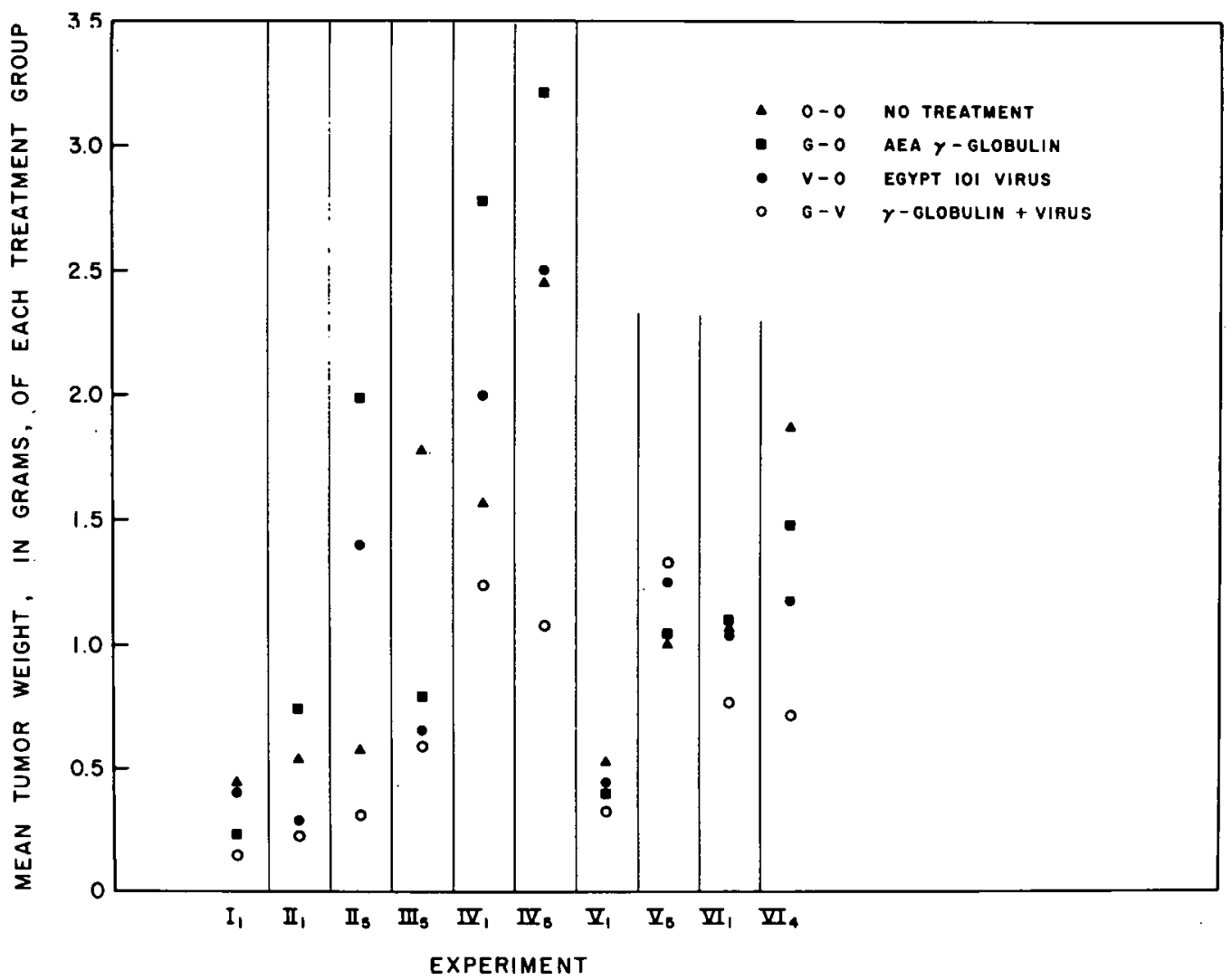

Figure 1. Mean tumor weight (in g) of each treatment group in each experiment. Subscripts after each experiment number indicate the day of death relative to the AEA $\gamma$-globulin injections.

\section{DISCUSSION}

It is interesting to note that in experiments IV and VI, a suppressive effect on tumor growth was seen. The mean tumor weight of the (G-V) group in these experiments was actually lower at the 4- or 5-day interval than at the 1-day interval, while mean tumor weights of the other 3 groups increased considerably with time (Figure 1). 
Since food intake was similar in all groups, this could not have been a factor in the lower tumor weights in the (G-V) group. Furthermore, the observations made under fasting conditions (experiment VI) were similar to those made when the mice were fed ad libitum.

One can only speculate about the lack of effect shown in the second portion of experiment V. Possibly the viral influence was less in this experiment. The passage of virus used in this experiment was not used in any other, and if, for some reason, the oncolytic effect was more evanescent in experiment $V$, the antibody may have been administered too late to take much advantage of it. Thus, in the mice which lived for 5 days after the $\gamma$-globulin injections, the (G-V) group may have been essentially a (G-O) group, in which AEA $\gamma$-globulin is useless when employed alone against a solid tumor. This corroborates the experiences of other investigators, and emphasizes the importance of careful timing of therapy in a complicated and dynamic hosttumor-virus relationship.

The authors gratefully express their appreciation to Dr. Dorothy M. Hamre, Dr. A. Lenore Sabet, and Mr. Toby Guinsatao for technical assistance, and to Dr. Paul Meier and Dr. Richard E. Tracy for help with the statistical analysis.

\section{LITERATURE CITED}

1. Wissler, R. W., P. A. Barker, M. H. Flax, M. F. La Via, and D. W. Talmage. Cancer Res., $16: 761,1956$.

2. Wissler, R. W., and M. H. Flax. Ann. N. Y. Acad. Sci., 69:773, 1957.

3. Flax, M. H. Cancer Res., 16:774, 1956.

4. Lindner, A. Am. J. Clin. Pathol., 34:426, 1960.

5. Horn, E. C. Cancer Res., 16:595, 1956.

6. Nichol, J. C., and H. F. Deutsch. J. Am. Chem. Soc., 70:80, 1948.

7. Moore, A. E. Ann. N. Y. Acad. Sci., 54:945, 1952.

8. Moore, A. E. Ann. Rev. Microbiol., 8:393, 1954.

9. Moore, A. E. Tex. Rep. Biol. Med., 15:588, 1957.

10. Southam, C. M., and A. E. Moore. Cancer, 5:1025, 1952.

11. Newman, W., and C. M. Southam. Cancer, 7:106, 1954.

12. Snedecor, G. W. Statistical Methods, 5th ed., Ames, Iowa: The Iowa State College Press, 1956, p. 251. 
TECHNIQUES FOR PARAMETRIAL_IRRADIATION USING COBALT-60 ${ }^{*}$

By

L. H. Lanzl, H. E. Brizel, ${ }^{\dagger}$ and E. M. Duthorn

Parametrial irradiation is almost univer sally accepted as essential to an adequate radiotherapeutic approach to carcinoma of the cervix. Intracavitary radium implants or transvaginal irradiation should adequately cover potential disease involving the vagina, cervix, uterus, and the immediate paracervical tissues, while external irradiation (regardless of exact procedure) should extend the maximal tolerated dose laterally to include all the broad and uterosacral ligaments together with the included lymphatic pathways.

The lymph nodes occupy fairly constant areas in the following locations:

1. The obturator or principal nodes may lie somewhat lateral to point B (revised Manchester method) ${ }^{1}$ and usually quite near the midpoint of the acetabulum.

2. The hypogastric nodes lie posteriorly in the sacroiliac area near the bifurcation of the common iliacs.

3. The external iliac nodes usually lie higher than the principal obturator nodes and anterior to the acetabulum.

4. The sacral and presacral nodes are posterior and adjacent to the upper sacral vertebra.

It is therefore necessary to irradiate a relatively large area of the pelvis in order that all the potential tumor may be treated. However, if additional irradiation of the midline structures via radium implants is indicated, the external irradiation should avoid an overdose to the bladder and rectum. Similarly, in delivering a cancerocidal dose, the radiotherapist must consider tissue tolerance of other uninvolved structures such as the femoral necks, subcutanenus tissue, and skin.

It is the purpose of this paper to compare three cobalt-60 techniques of external irradiation with respect to (1) adequate coverage of tumor, (2) particular application of each technique, and (3) sparing of uninvolved normal structures. These techniques will be evaluated in part on relative depth dose measurements determined by exposing a phantom containing $x$-ray film to the appropriate gamma ray beams of either fixed or moving fields.

The cobalt-60 therapy unit employed in this study has been described previously. ${ }^{2}$ It is designed for horizontal rotation therapy, i.e., the patient is placed horizontally on a cot and the gamma ray beam moves circumaxially about the long axis of the patient. The phantom ${ }^{3}$ is composed of a plastic based on a synthetic isocyanate rubber and contains a natural skeleton. It is sectioned transversely into $2.5-\mathrm{cm}$ layers which are held together by means of a clamping device. The sections are held rigidly together during irradiation by nylon cords under tension. Film is loaded between successive layers with the edge taped to prevent light leakage (see Figure 1). After development, the film is read on a Macbath-Ansco densitometer, and analyzed as

${ }^{*}$ A slightly abridged version of this paper will appear in Am. J. Roentgenol., Radium Therapy and Nuclear Medicine.

${ }^{\dagger}$ Department of Radiology, University of Louisville, Louisville, Kentucky. 


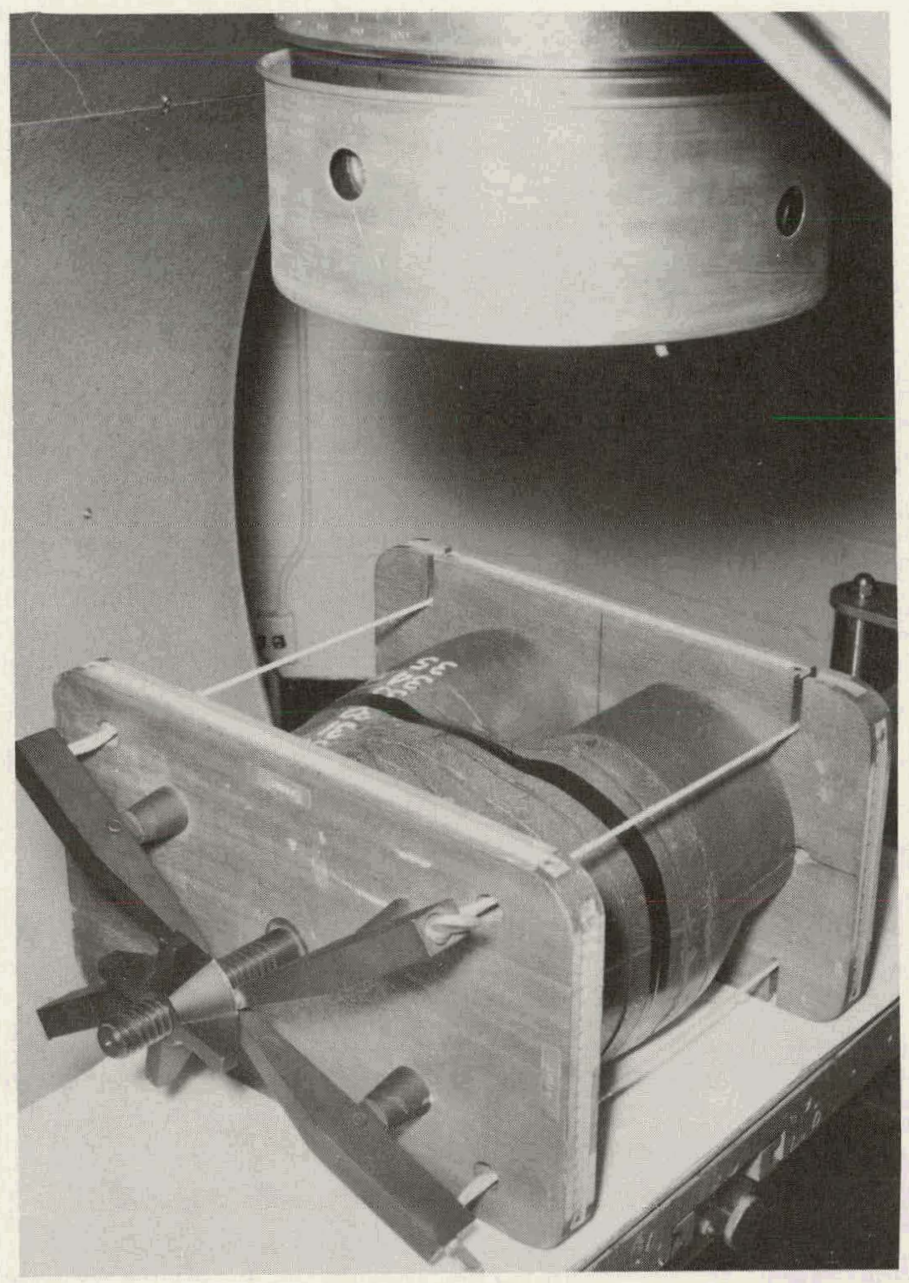

Figure 1. Photograph showing portion of phantom (below) under cobalt-60 irradiation. Interface of sections containing film is taped to prevent light leak. Source shield is shown on the top of the picture.

reported earlier. ${ }^{4}$ The film used, namely Eastman Kodak Industrial X-ray AA, is a more sensitive form of the type employed previously.

\section{TECHNIQUES}

(a) Opposing fixed ports. Conventional parametrial irradiation implies the use of opposing orthovoltage or cobalt-60 portals. In general, a $4-\mathrm{cm}$ separation of the fields in the midpelvis is considered adequate; this may be accomplished by using one field with lead shielding in the midline, or two separate anterior and posterior fields with adequate central separation.

The dose distribution for two separate anterior and posterior fields is shown in Figure 2. The location of the pelvic bones, bladder, rectum, and vagina is indicated in the figure. An arbitrary point, C.P., is taken as the basic reference center. The points C.C. indicate the centers of crossfire. It is at the depth of these points within the phantom that the field size, namely 


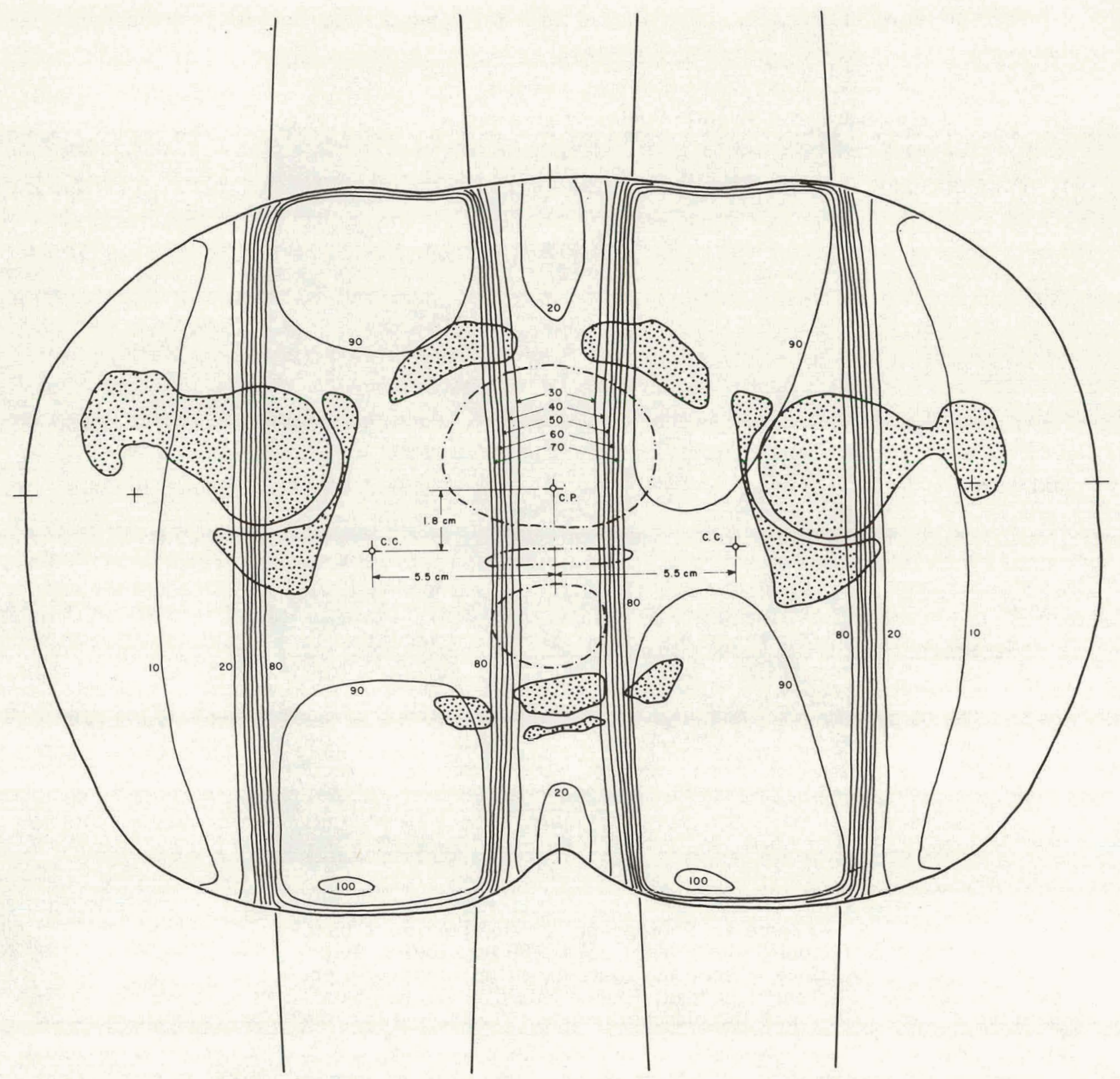

Figure 2. Isodose distribution of cobalt-60 gamma radiation for four equal fixed fields in opposing pairs. The field size is: $7 \times 15 \mathrm{~cm}$ at centers of crossfire (C.C.). The phantom is heterogeneous with the distribution measured between sections $32-$ 33. Bone is stippled. The bladder, vagina and rectum are indicated by a broken line. The point C.P. is taken as the basic reference center.

$7 \times 15 \mathrm{~cm}$, is prescribed. The center of crossfire is at the center of each given irradiation field. In this case, the centers of crossfire are separated by $11 \mathrm{~cm}$ and lie $1.8 \mathrm{~cm}$ posteriorly to the reference center. The apparent lateral asymmetry of the $90^{\circ}$ isodose lines is due to an error of \pm 5 per cent for the method of measurement employed, which is conspicuous here because of the low dose gradient in this region. These measurements show that the opposing fixed ports give a peak dose just below the skin surface rather than at the midpelvic line. 
The simplicity of this setup is evident. Concerning dose distribution, there are several salient features:

1. The low dose (10 per cent) to femoral necks

2. The low dose (25 per cent) to midline structures

3. The fairly homogeneous dose in the parametrial area

4. The higher dose to subcutaneous tissues than to the tumor (15-20 per cent greater).

(b) Sector technique. By using sector techniques, one attempts to treat the same tumorbearing area as that treated with opposing ports, but because of the geometry, the dose distribution is considerably and beneficially different. The setup is more complex than that used for opposing ports. The two sector techniques to be discussed comprise: 1) four sectors, each extending over $85^{\circ}$, with a $7 \times 15-\mathrm{cm}$ field size at the center of rotation and 2) four sectors of $60^{\circ}$ each, with a $5 \times 15-\mathrm{cm}$ field size. Their relative dose distributions are shown in Figures 3 and 4. The point C.R. indicates the position of the centers of rotation in each case. These are located $11 \mathrm{~cm}$ apart and $1.8 \mathrm{~cm}$ posteriorly to the reference center. In these distributions, the dose maximum lies in the mid-plane of the pelvis. As is usual with moving field beams, the skin dose is far lower than for the fixed-field beams. The $60^{\circ}$ sector technique yields an elongated 80 per cent isodose line and a comparatively low dose at the immediate paracervical tissues. On the other hand, the $85^{\circ}$ sector technique yields a more circular distribution about the centers of revolution, with a higher dose to the immediate paracervical area.

From the isodose patterns of the $60^{\circ}$ and the $85^{\circ}$ sectors, one notes that:

1. The femoral necks receive a low dose (10 per cent).

2. The $85^{\circ}$ sector contributes a fairly high dose to mid-line paracervical structures (50 - 70 per cent), while the $60^{\circ}$ technique gives considerably less ( 30 - 40 per cent); the opposing port technique contributes least ( 25 per cent).

3. Node areas receive homogeneous doses with both techniques. The $60^{\circ}$ sector extends the zone of effective radiation slightly more anteriorly and posteriorly than the $85^{\circ}$ sector.

4. Subcutaneous tissues receive less radiation than potential tumor-bearing areas with both sector techniques.

Some estimates of integral dose, based solely on the two-dimensional distributions presented here, were made. The location of the tumor for the estimates of integral dose were as shown in Figure 5 . The total integral doses with the fixed-field and the $85^{\circ}$ sector were respectively, 7 per cent and 23 per cent higher than those of the $60^{\circ}$ sector. It should be remembered, however, that the field size is smaller with the $60^{\circ}$ sector. Assuming that the tumor involves the previously described node areas, rough estimates were also made for the ratios of tumor integral dose to total integral dose. These were 24,26 and 22 per cent for the fixed field, $60^{\circ}$ sector, and $85^{\circ}$ sector cases, respectively.

\section{DISCUSSION}

Theoretically, the primary tumor site has received adequate radiation from radium or transvaginal $x$-ray, and there should be no necessity for adding to this dose with external therapy. However, many factors, such as anatomical variation, extent of tumor, and associated pelvic infection may either prevent initial radium insertion or cause a compromise in the dose distribution obtained therefrom. This being the case, split opposing ports which deliver a very 


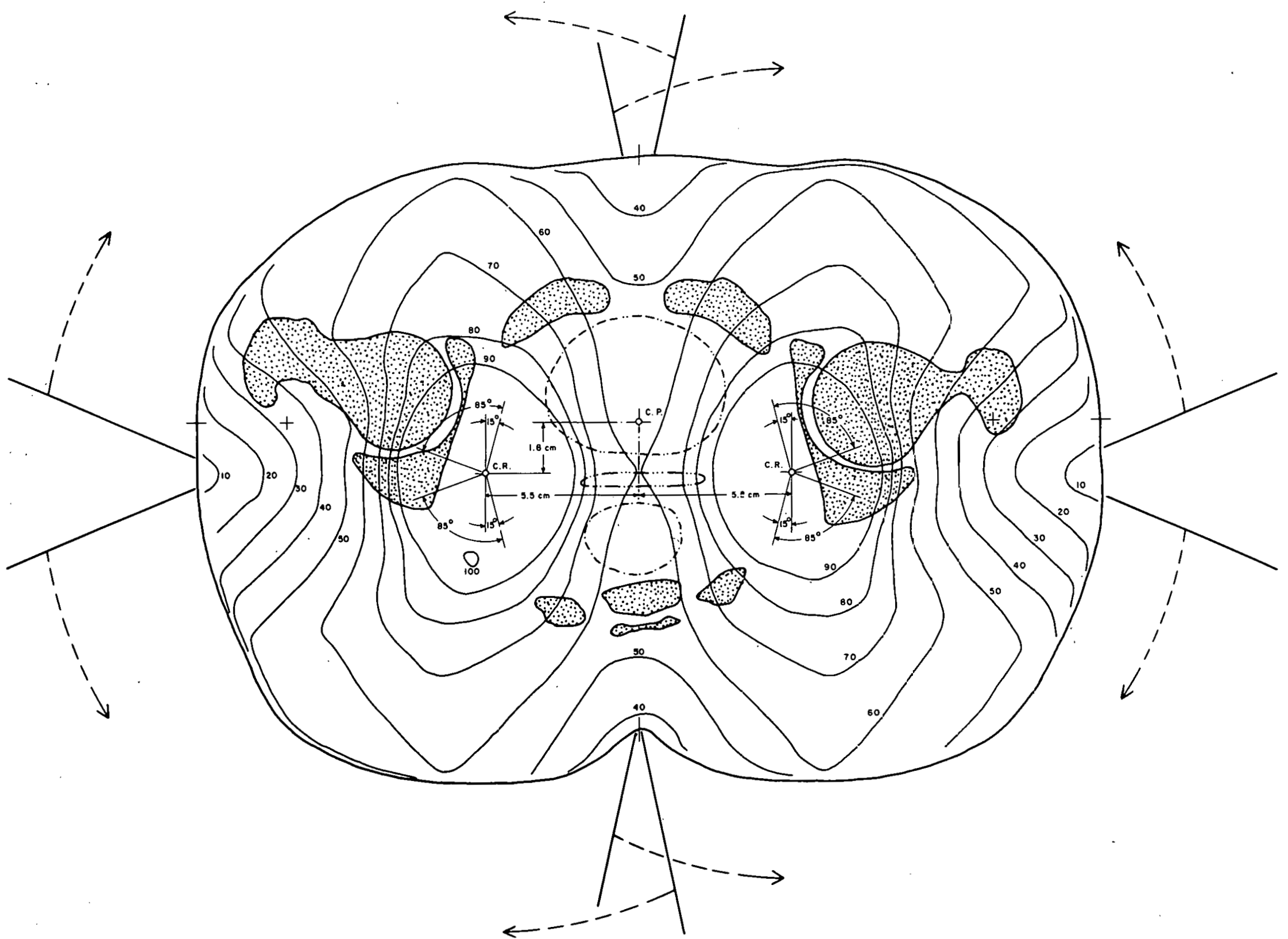

Figure 3. Isodose distribution of cobalt-60 gamma radiation for four moving field sectors each $85^{\circ}$. The field size is $7 \times 15$ $\mathrm{cm}$ at the centers of rotation (C.R.). 


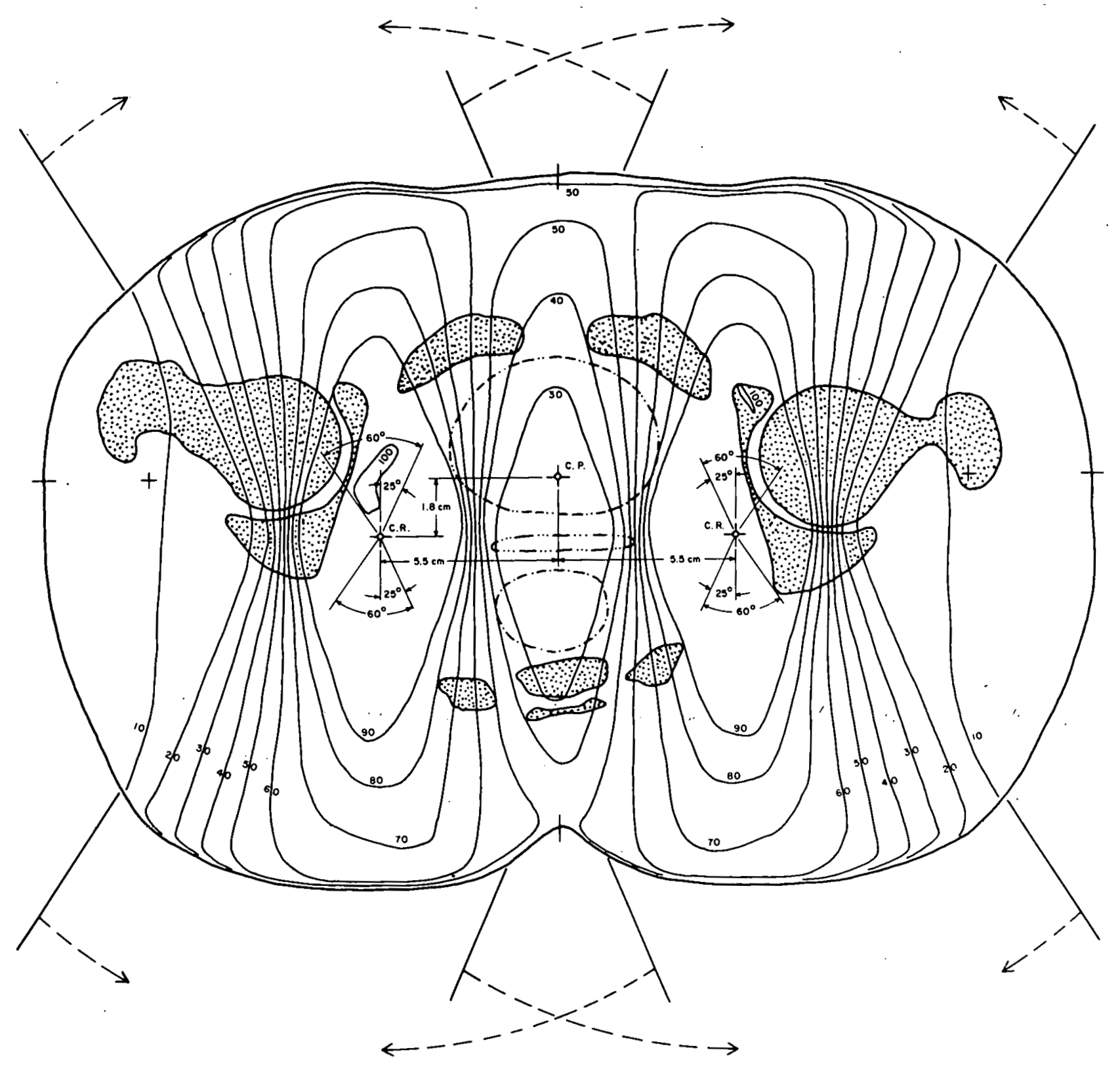

Figure 4. Isodose distribution of cobalt- 60 gamma radiation for four moving field sectors each $60^{\circ}$. The field size is $5 \times 15 \mathrm{~cm}$ at the centers of rotation (C.R.).

low dose to the midline, paracervical structures would be a poor choice for preliminary irradiation intended to improve the situation for radium insertion.

Of the two sector plans, the $60^{\circ}$ one gives only a slightly better dose to the centrally located tumor-bearing structures than the fixed opposing ports, and has no obvious advantage in the previously described situation. With the $85^{\circ}$ sector, however, there is a good "blending" of dose to the midline. This technique, then, would seem to be appropriate for a situation where preliminary external treatment is given to facilitate subsequent radium therapy, and the same technique could then be continued to achieve the desired lateral pelvic dose. 


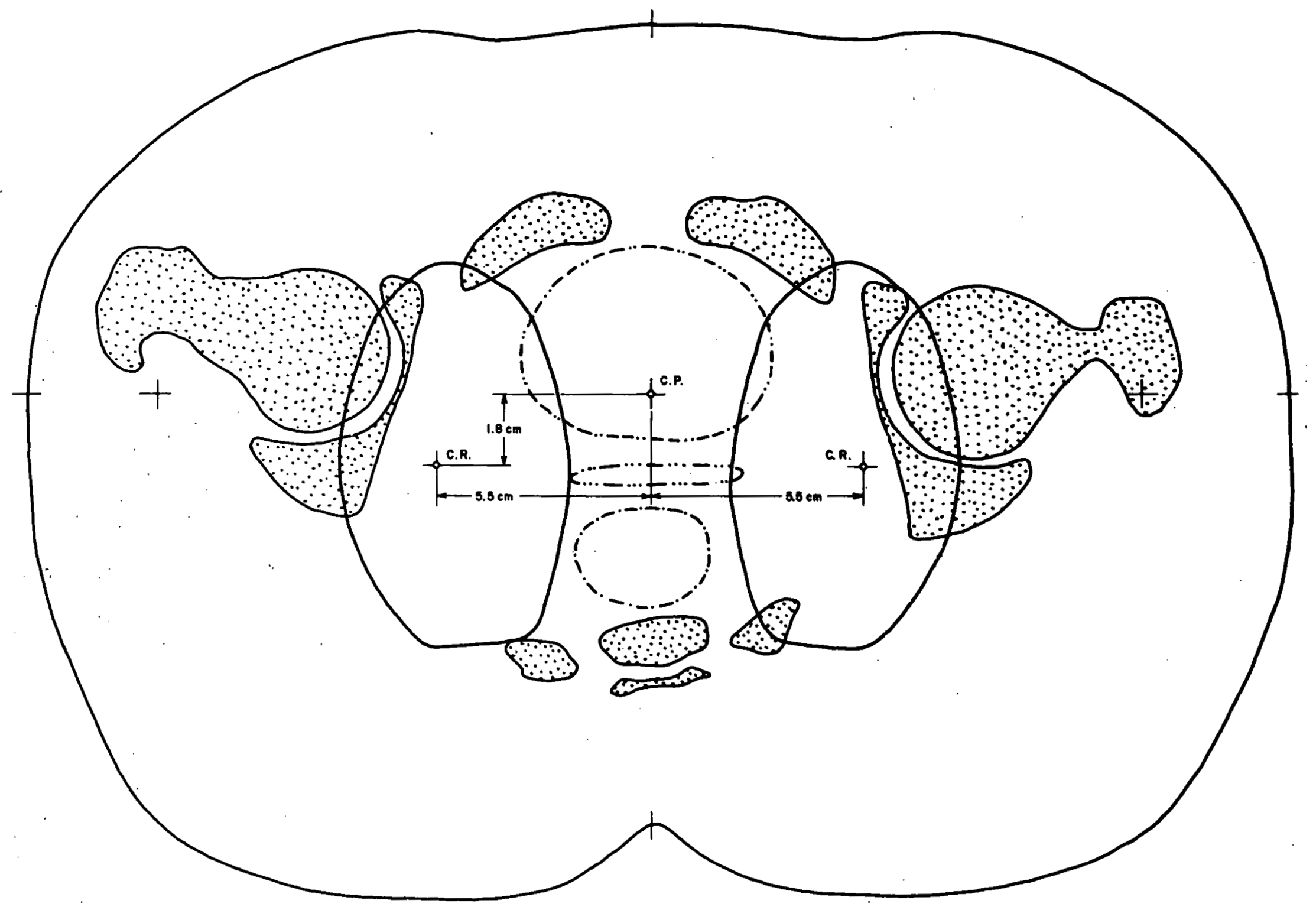

Figure 5. The tumor areas were assumed to be within the two heavy contour lines shown on either side of the midline structures. These areas were used to estimate the integral dose under the various modes of treatment described in this paper. 
Skin tolerance is not a problem in any of the three cobalt-60 techniques described, but the isodose patterns reveal that the subcutaneous tissues receive the maximum dose with split opposing fixed ports, while the tumor area receives the maximum dose with the rotational method. While this dose maximum in the subcutaneous tissues with the opposing fixed ports may be clinically insignificant if the tumor dose is kept within the usually accepted range, it is an unnecessary burden to the patient if it can be satisfactorily avoided.

A further comparison of the three techniques via "integral dose," reveals no apparent significant difference. In any event, all three approaches are clinically well tolerated by the patient.

\section{CONCLUSION}

If rotational cobalt- 60 is available, there should be no real necessity to employ straight opposing ports for external irradiation to cancer of the cervix.

The $60^{\circ}$ sector would seem indicated when the various factors for intracavitary or transvaginal irradiation are optimal and only the structures lateral to the paracervical areas need supplementary treatment.

The $85^{\circ}$ sector should be very well suited for complicated cases in which significant preradium $x$-ray therapy to midline structures is necessary, but for which one still wishes to make use of the other advantages of the $60^{\circ}$ sector.

Although the sector techniques have a complex alignment procedure, the extra precautions necessary should be ultimately rewarding.

The authors wish to express their appreciation to Drs. J. W. J. Carpender and M. L. Griem for their review of the manuscript, to Dr. W. A. Jennings who originally introduced the $85^{\circ} \mathrm{sec}-$ tor technique to our department, to Dr. Stanley Dische of Jefferson Medical School who suggested the evaluation of this particular $60^{\circ}$ sector technique, and to Mr. Alex Juchnevicius who prepared the graphs for this paper.

\section{LITERATURE CITED}

1. Tod, M., and W. J. Meredith. Brit. J. Radiol., 26:252, 1953.

2. Lanzl, L. H., D. D. Davison, and W. J. Raine. Am. J. Roentgenol., Radium Therapy and Nuclear Med., 74:898, 1955.

3. Alderson, S. W., L. H. Lanzl, M. Rollins, and J. Spira. Am. J. Roentgenol., Radium Therapy and Nuclear Med., 87:185, 1962 .

4. Lanzl, L. H., and L. S. Skaggs. Am. J. Roentgenol., Radium Therapy and Nuclear Med., $80: 851,1958$. 


\section{PRELIMINARY OBSERVATIONS ON THE USE OF SEX-HOUR Tc ${ }^{99 m}$ AS A TRACER IN BIOLOGY AND MEDICINE}

By

P. V. Harper, G. Andros, ${ }^{\dagger}$ and K. Lathrop

Technetium $-99 \mathrm{~m}^{1}$ appears to show sufficient promise as a tracer material in biology and medicine to warrant detailed investigation. The short half-life of six hours, the near absence of particle radiation, and the low energy $(140 \mathrm{KEV})$ of its principal gamma ray, suggest that in such applications as radiocardiography, count rates might be obtained which would be several orders of magnitude greater than those possible with $\mathrm{I}^{131}$ tagged albumin, without increasing the radiation dosage to the patient.

Although technetium (atomic number 43 ) was observed first in the stars, twenty-one isotopes and metastable states ${ }^{2}$ have been prepared by nuclear bombardment or nuclear fission. Technetium behaves ${ }^{2}$ most like rhenium, its sister element in the seventh periodic group. Both form a stable $\mathrm{XO}_{4}{ }^{-}$anion in which state they may be metabolically handled. In this form the vapor pressure is considerable, so that solutions may not be boiled without appreciable loss. However, within the relatively narrow limits of biological variation of temperature, redox potential, $\mathrm{pH}$, etc., technetium remains quite stable as the pertechnetate.

The principal (99 per cent) gamma radiation has an energy of $140 \mathrm{KEV}$ and there is no other significant radiation apart from conversion electrons and fluorescent $\mathrm{x}$-rays ( 7.5 per cent). The gamma radiation has a narrow beam half-value layer of $4.6 \mathrm{~cm}$ in tissue and $0.4 \mathrm{~mm}$ in lead, so that its characteristics are ideal for external scanning, with good tissue penetration and ease of shielding and collimation. The activity of the daughter $\mathrm{Tc}^{99}$ is negligible since one curie of $\mathrm{Tc}^{99 \mathrm{~m}}$ decays to $3.26 \times 10^{-3} \mu \mathrm{c}$ of $\mathrm{Tc}^{99}$.

$\mathrm{Tc}^{99 \mathrm{~m}}$ is available carrier-free as the daughter of 2.6 day $\mathrm{Mo}^{99}$ (see Figure 1) which is isolated from fission products, and may be procured from Brookhaven National Laboratory in $100 \mathrm{mc}$ quantities adsorbed on alumina. From this, the daughter $\mathrm{Tc}^{99 \mathrm{~m}}$ may be eluted daily for approximately two weeks. When the daughter $\mathrm{Tc}^{99 \mathrm{~m}}$ is in equilibrium with its parent $\mathrm{Mo}^{99}$, one new atom of $\mathrm{Tc}{ }^{99 \mathrm{~m}}$ is formed for every one which decays, and consequently for each millicurie of $\mathrm{Mo}^{99}$ there is present approximately one millicurie of $\mathrm{Tc}^{99 \mathrm{~m}}$. Since the daughter isotope has a half-life of six hours, it builds up again to approximately 95 per cent of equilibrium activity in 24 hours after elution, the yield thus being about $100 \mathrm{mc}$ of $\mathrm{Tc}^{99 \mathrm{~m}}$ on the first day, $70 \mathrm{mc}$ on the second, $50 \mathrm{mc}$ on the third and so on, as the parent $\mathrm{Mo}^{99}$ decays with a 2.6 day half-life. A total of about $450 \mathrm{mc}$ can thus be eluted from a $100 \mathrm{mc} \mathrm{Mo}{ }^{99}$ column over a period of two weeks.

Clinical applications and dosimetry of this isotope require a knowledge of the time relationships of its distribution within the various parts of the body. The present report is concerned

\footnotetext{
* This paper was presented before the Chicago Clinical Society, April 1962 and was awarded the Society's 2nd prize. It was also presented at the Radiation Research Society, Colorado Springs, May'1962, and at the Society for Nuclear Medicine, Dallas, June 1962.

$\dagger$ Present address: National Cancer Institute, National Institutes of Health, Bethesda 14, Maryland.
} 


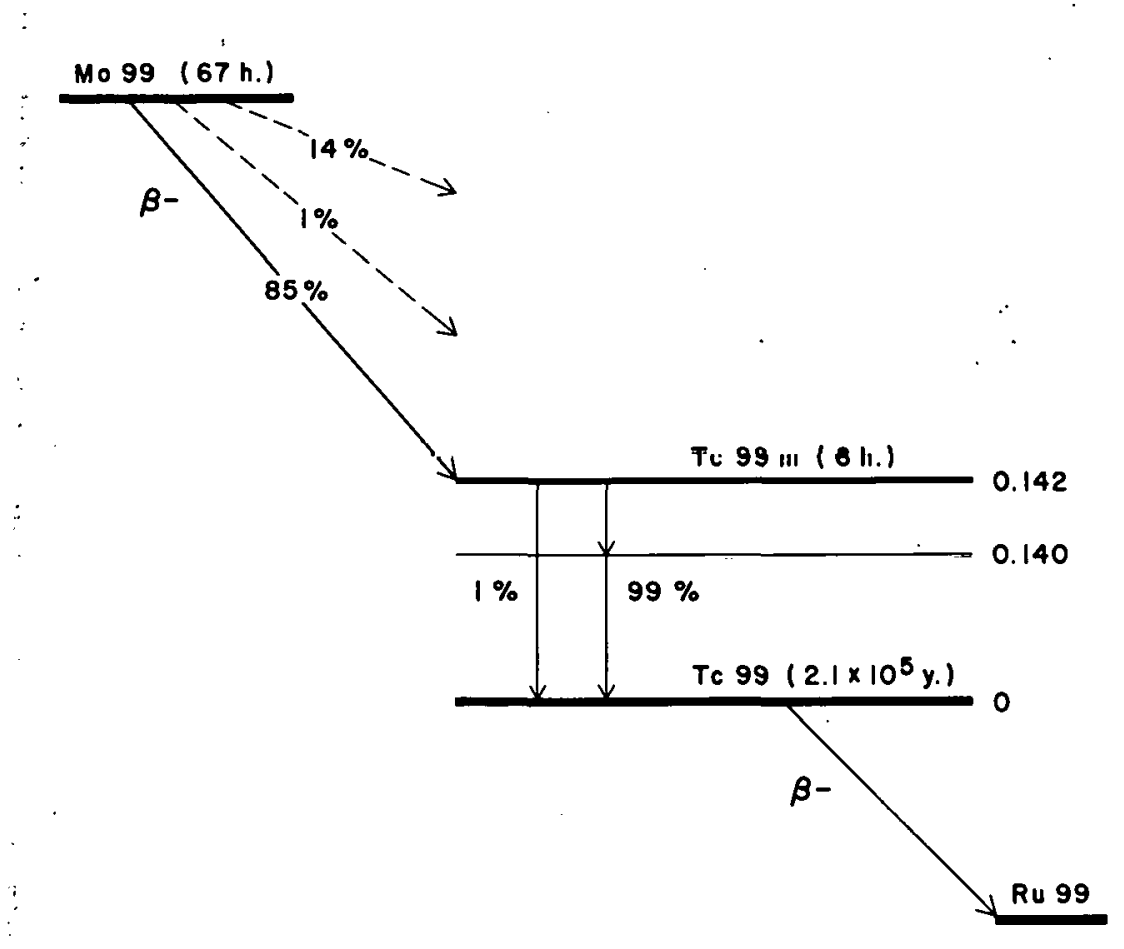

Figure 1. Technetium ${ }^{99 m}$ genetic relationships.

with such observations in a variety of experimental animals and man.

In most instances group VIrb elements (the halogens) in the $\mathrm{X}^{-}$and $\mathrm{XO}_{4}{ }^{-}$forms and also the group VIIa elements (manganese, technetium and rhenium) as $\mathrm{XO}_{4}{ }^{-}$ions are known to concentrate to varying degrees in the thyroid gland, salivary glands and gastric mucosa. ${ }^{3,4}$ Only one of these elements (iodine as $\mathrm{I}^{-}$), is known to enter into organic combination. It is possible that this comparable behavior is due to similarity of molecular size and configuration, ${ }^{5}$ and in many cases competition for localization has been demonstrated. ${ }^{6,7}$

\section{METHODS}

Carrier free $\mathrm{Tc}^{99 \mathrm{~m}}$ eluted with $20 \mathrm{ml}$ of $0.1 \mathrm{~N} \mathrm{HCl}_{3}$ from $\mathrm{Mo}^{99}$ adsorbed on alumina was brought to a $\mathrm{pH}$ of 5.5 with $\mathrm{NaOH}$ and then diluted to the desired specific activity with normal saline. All animals studied were maintained on the normal stock diet containing the usual iodine supplement.

Blood and plasma disappearance curves were determined using $2.0 \mathrm{ml}$ samples of heparinized blood drawn at 1-2 minute intervals for the first 10-15 minutes following intravenously administered $\mathrm{Tc}^{99 \mathrm{~m}}$, and at increasingly longer intervals thereafter. All samples were taken from separate venipunctures on alternating extremities. Blood and plasma samples were counted against an injection standard in a 1-1/2" NaI well-type scintillation crystal.

Localizations at various times after intravenous or intracardiac injections of $20-40 \mu \mathrm{c}$ of $\mathrm{Tc}^{99 \mathrm{~m}}$ were observed in mice and guinea pigs using the small animal scanner developed at the Argonne Cancer Research Hospital. Scans of humans were made with a Picker Magnascanner 30 minutes after intravenous injection of $\mathrm{Tc}^{99 \mathrm{~m}}$.

Thyroid uptake ratios were determined on anesthesized 8-week-old CF No. 1 mice from 
measurements of the radioactivity in about $1.0 \mathrm{ml}$ of blood from the thoracic aorta and in excised thyroids removed one hour after intravenous injection of $20 \mu \mathrm{c} \mathrm{Tc} 99 \mathrm{~m}$. The thyroids were weighed within 60 seconds of excision and digested in $2 \mathrm{ml}$ of $6 \mathrm{~N} \mathrm{NaOH}$ for counting. The thyroid/serum ratio is defined ${ }^{8}$ as the amount of radioactivity in the gland divided by the radioactivity in an equal volume of serum. Saliva/serum and gastric juice/serum ratios were measured in a similar way. The effects of thyroid stimulation were determined from measurements made on serum and thyroids removed one hour following administration of $\mathrm{Tc}^{99 \mathrm{~m}}$ to mice injected intravenously with 0.2 units of TSH (Armour) 36 hours previously. TSH suppression was studied similarly by administering $10 \mu \mathrm{g}$ L-thyroxine subcutaneously for three successive days before injection of $\mathrm{Tc}^{99 \mathrm{~m}}$ on the fourth day. Measurements of radioactivity in urinary and fecal excretions were determined using a well-type scintillation counter.

Radiocardiograms or "isotope dye curves" were measured over the precordium in dogs and human subjects. A $1 / 4$ " thick sodium iodide crystal 3 " in diameter was used at 8 inches from the chest with a collimator of $1 / 8$ " lead sheeting which defined a cylindrical sensitive volume approximately equal in diameter to the heart. Fifty to $400 \mu \mathrm{c}$ of technetium was injected into the anticubital vein. The output from the detector was led through a linear amplifier and a single channel pulse height analyzer. The pulses were then scaled down by a factor of 32 and led to a digital rate meter which recorded the input pulses in channels 0.02 to 0.1 seconds wide. This assembly was able to handle 5,000 to 10,000 counts per second without significant loss, thus greatly improving the statistics and introducing no rate meter distortion.

\section{RESULTS}

Figure 2 shows scans of a mouse at 9, 47, and 120 minutes after intravenous injection of $40 \mu \mathrm{c}$ of $\mathrm{Tc}^{99 \mathrm{~m}}$. The immediate thyroid and gastric localization and the increasing urinary excretion with time are demonstrated. Removal of the stomach in two animals at one-half hour revealed a localization of 25 per cent and 23 per cent of the injected $\mathrm{Tc}^{99 \mathrm{~m}}$ in this organ and its contents.

The inhibition in $\mathrm{TcO}_{4}{ }^{-}$uptake by previously administered iodide and perchlorate is shown in Figures 3 and 4. Figures 5 and 6 show the discharge of $\mathrm{Tc}^{99 \mathrm{~m}}$ from the thyroid and stomach by iodide and perchlorate given after localization has taken place. Figure 7 shows the similar deposition of $\mathrm{Tc}^{99 \mathrm{~m}}$ in the untreated guinea pig where the localization in the salivary glands is especially prominent.

Blood disappearance curves in rabbits, dog and man (Figure 8) show a similar configuration with a rapid component $(\mathrm{T} 1 / 2=10 \mathrm{~min}$ ) and a slow component ( $\mathrm{T} 1 / 2=6$ hours $)$. It was initially thought that the rapid component represented concentration in the stomach and thyroid and the slow component renal excretion. However, similar blood disappearance curves were observed in thyroidectomized, gastrectomized and nephrectomized dogs (Figure 9). The rapid component would therefore seem to be due largely to equilibration with interstitial fluid rather than concentration in the thyroid and stomach, and the slow component to represent mainly intracellular penetration rather than renal excretion. This interpretation is supported also by the fact that pretreatment with $\mathrm{NaClO}_{4}$ did not appreciably alter the shape of the blood disappearance curve.

Measurements of the thyroid/serum ratios were made in CF No. 1 mice at increasing intervals after administration of $\mathrm{Tc}^{99 \mathrm{~m}}$ (Table 1). The effect of $\mathrm{TSH}^{9}$ and suppression of TSH by 


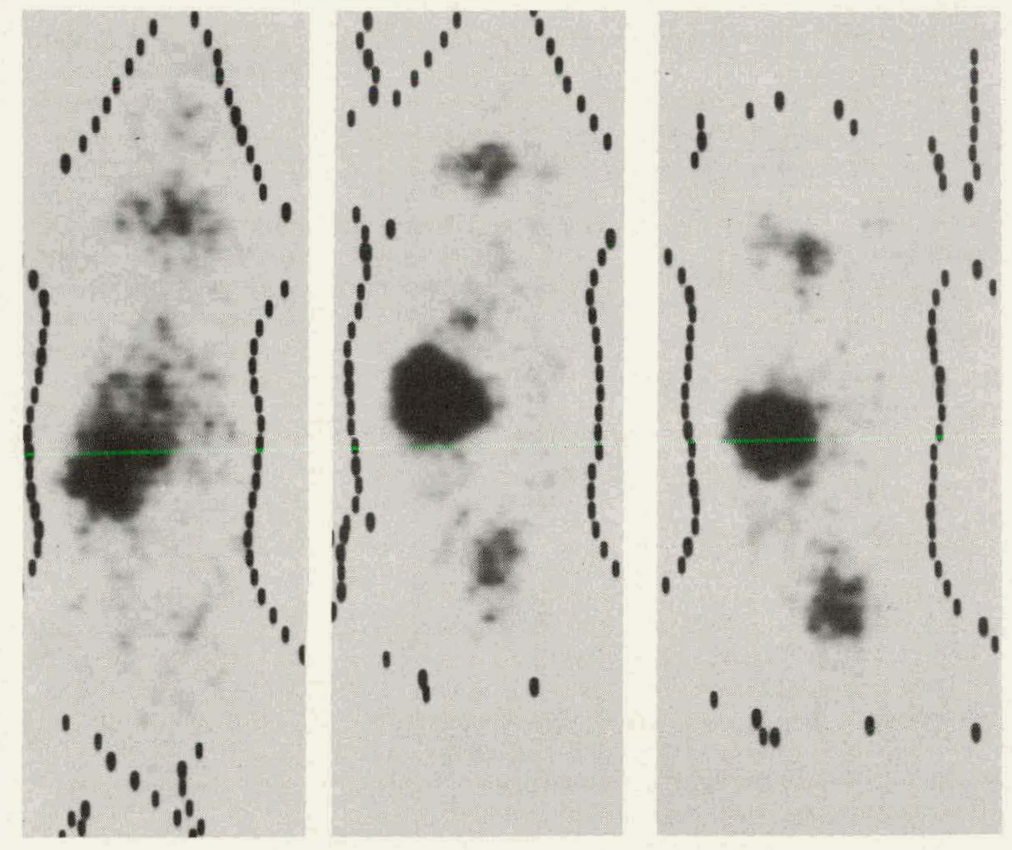

Figure 2. Scans of a mouse showing localization of intravenous $\mathrm{Tc}^{99} \mathrm{mO}_{4}{ }^{-}$at (a) 9 minutes, (b) 47 minutes and (c) 120 minutes. Note persistence of radioactivity in thyroid and stomach as urinary excretion increases.
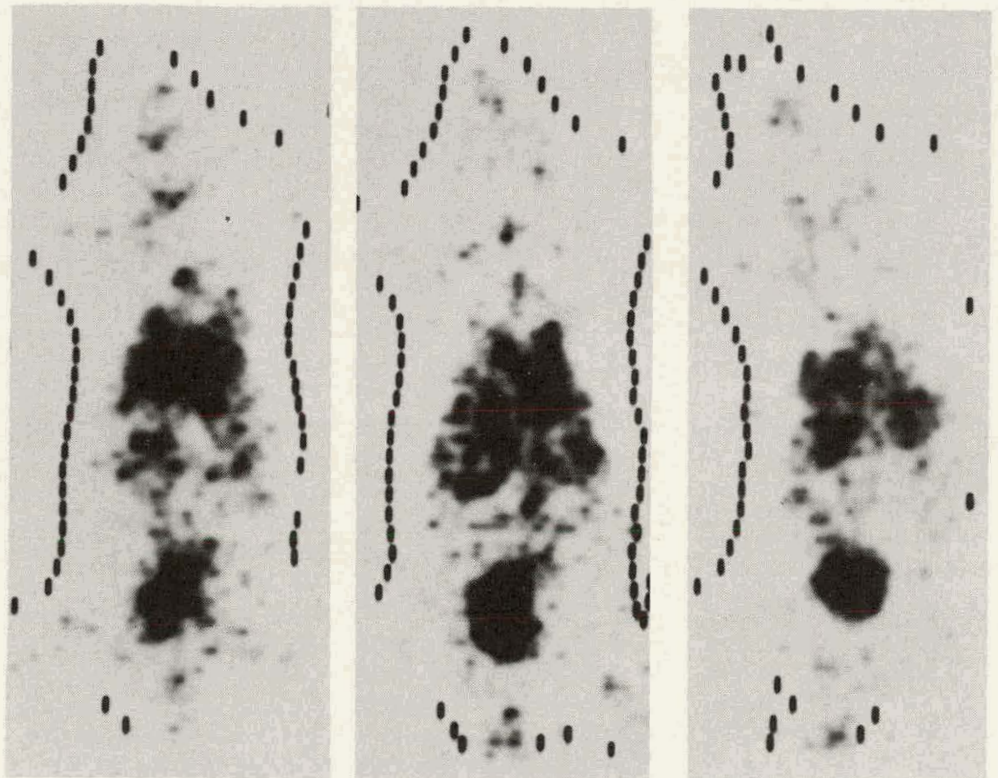

Figure 3. Scans of a mouse pretreated with $5 \mathrm{mg}$ of intravenous NaI 30 minutes before intravenous

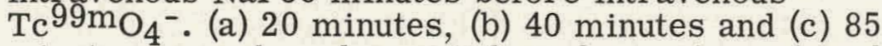
minute scans show decreased uptake in stomach and thyroid compared to the untreated animal of Figure 2. 

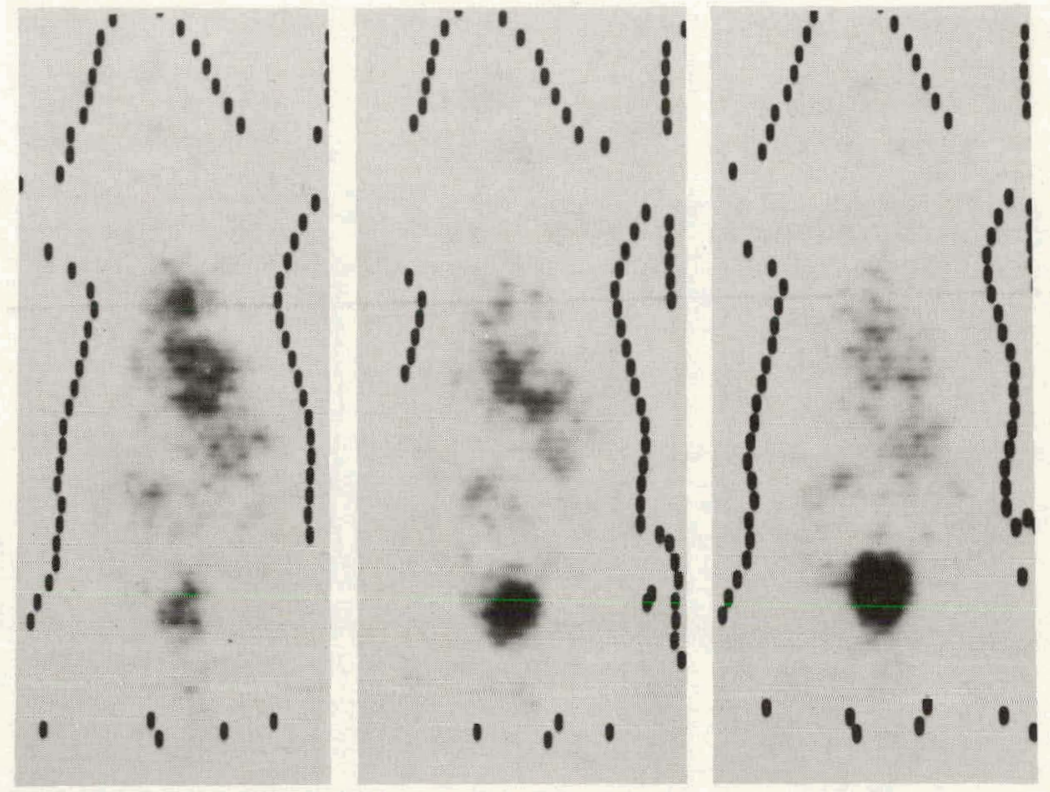

Figure 4. Scans of a mouse pretreated with 5 $\mathrm{mg}$ of intravenous $\mathrm{NaClO}_{4} 30$ minutes before in-

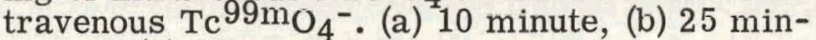
ute and (c) 45 minute scans show almost complete inhibition of uptake by stomach and thyroid.
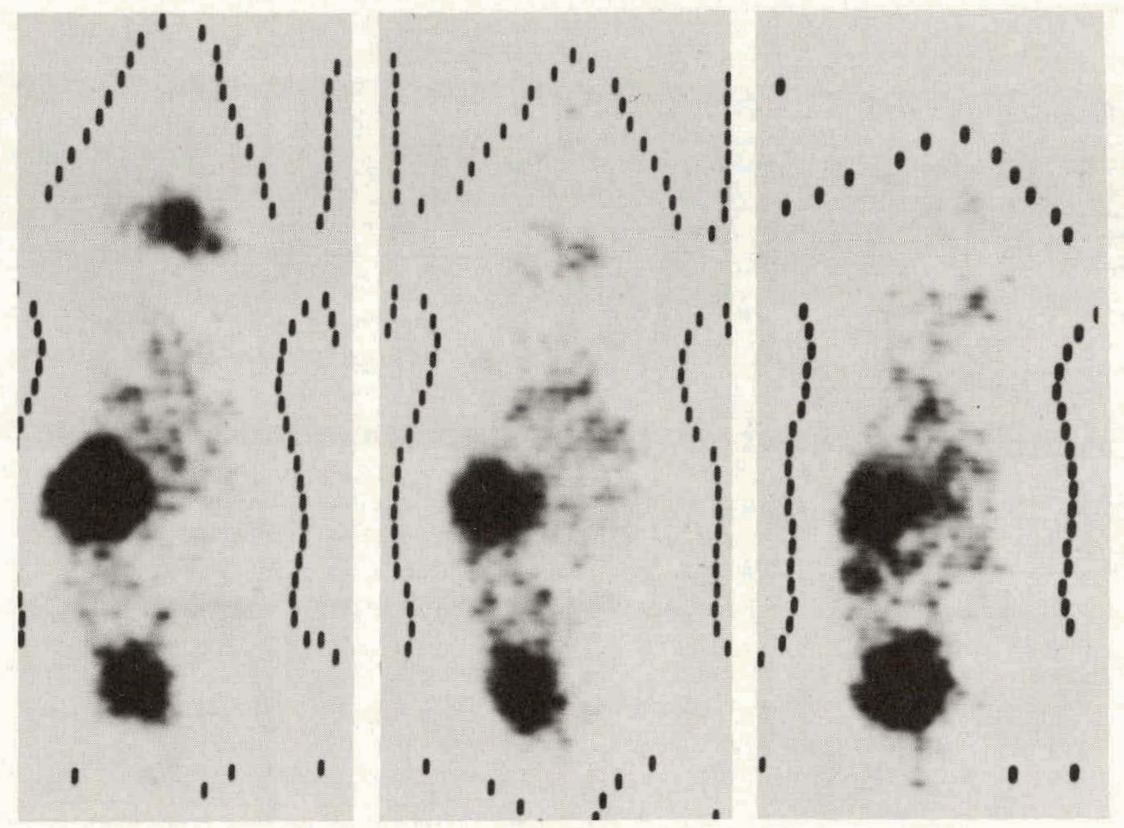

Figure 5. Effect of iodide on $\mathrm{TcO}_{4}{ }^{-}$localization - (a) 44 minutes after $\mathrm{Tc}^{99} \mathrm{~m}_{4^{-}}{ }^{-}$. At 56 minutes, $5 \mathrm{mg}$ of intravenous $\mathrm{NaI}$ were given and scans made (b) 20 minutes and (c) 54 minutes later. Note decrease of radioactivity in thyroid following NaI. 

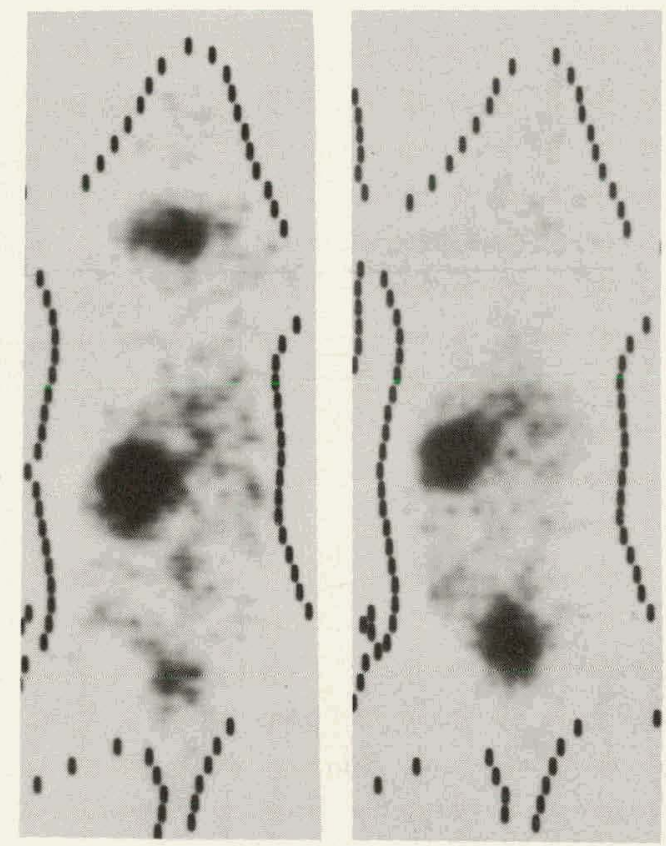

Figure 6. Effect of $\mathrm{ClO}_{4}^{-}$on Tc $99 \mathrm{mO}_{4}-$ localization (a) 25 minutes after $\mathrm{Tc}^{99 \mathrm{~m}_{4}}{ }^{-}$. At 63 minutes, $5 \mathrm{mg}$ of intravenous $\mathrm{NaClO}_{4}$ were given and scan (b) made 27 minutes later. Note decrease of radioactivity in thyroid in (b).
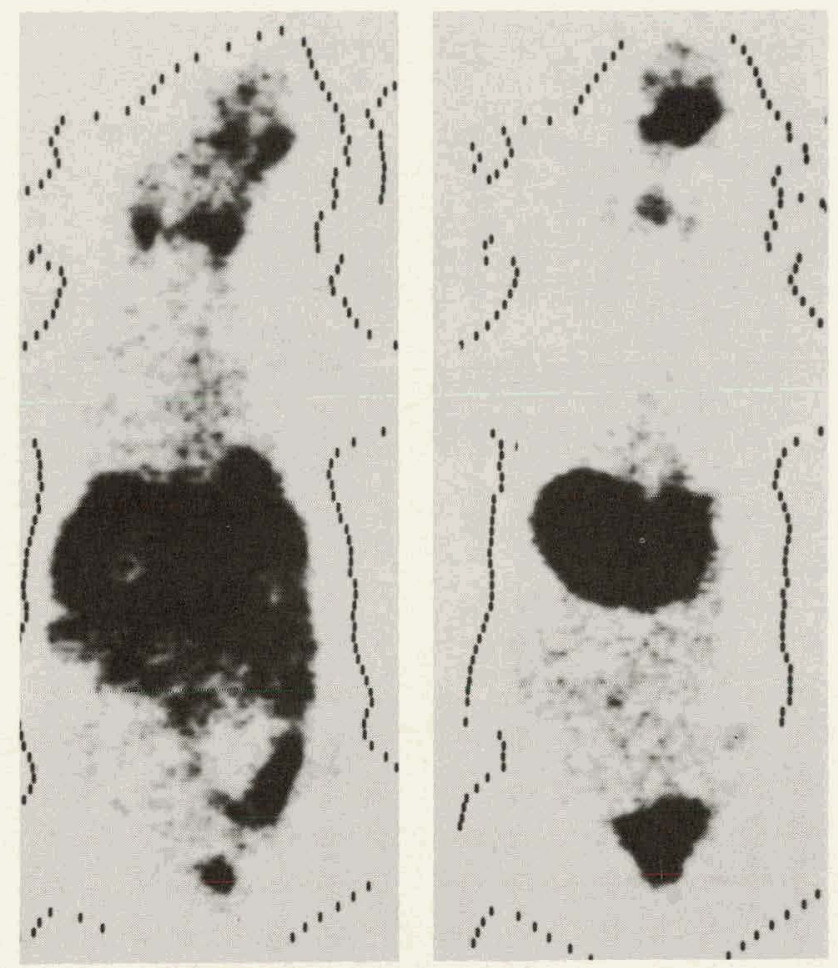

Figure 7. Scans of an albino guinea pig made at 5 and 90 minutes following intracardiac Tc $99 \mathrm{~m}$. Besides thyroid and gastric concentrations, salivary gland concentration is well shown.

Table 1

Tc $^{99 m}$ THYROID/SERUM RATIOS AND THYROID UPTAKE IN THE MOUSE FOLLOWING INTRAVENOUS INJECTION (6 TO 8 MICE PER GROUP)

\begin{tabular}{c|c|c}
\hline $\begin{array}{c}\text { Minutes after } \\
\text { injection }\end{array}$ & $\frac{\text { Thyroid }}{\text { serum }}$ & $\begin{array}{c}\text { Injected dose } \\
\text { in thyroid } \\
\text { (per cent) }\end{array}$ \\
\hline 2 & $12.6 \pm 6.6$ & $0.11 \pm 0.4$ \\
5 & $16.1 \pm 7.5$ & $0.13 \pm 0.04$ \\
10 & $24.1 \pm 4.3$ & $0.17 \pm 0.05$ \\
30 & $48.4 \pm 11.0$ & $0.27 \pm 0.06$ \\
60 & $80.5 \pm 28.8$ & $0.73 \pm 0.21$ \\
120 & $87.8 \pm 25.8$ & $0.43 \pm 0.11$ \\
\hline
\end{tabular}




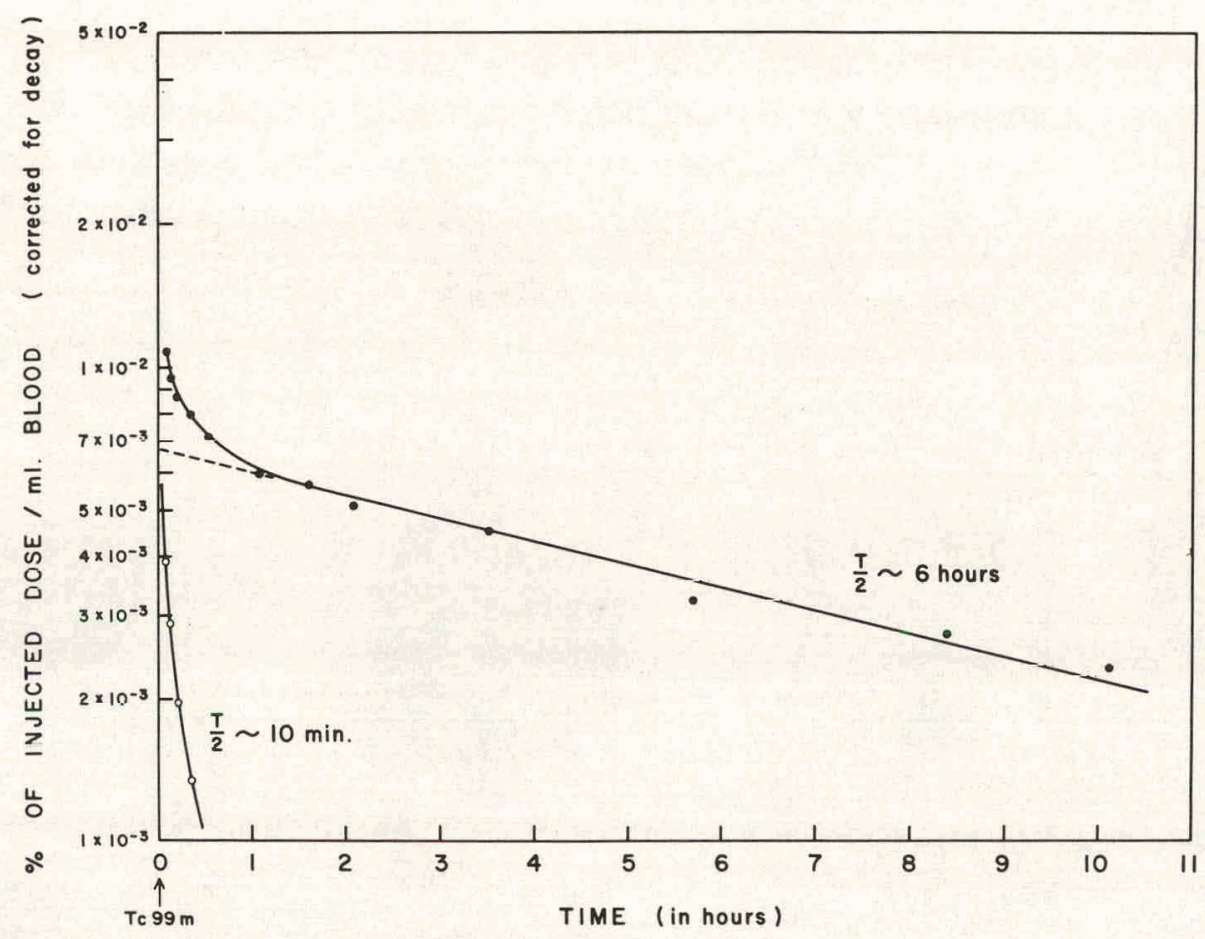

Figure 8. Blood disappearance of $\mathrm{Tc}^{99 \mathrm{~m}}\left(\mathrm{as} \mathrm{TcO}_{4}{ }^{-}\right)$in a $57 \mathrm{~kg}$ caucasian female.

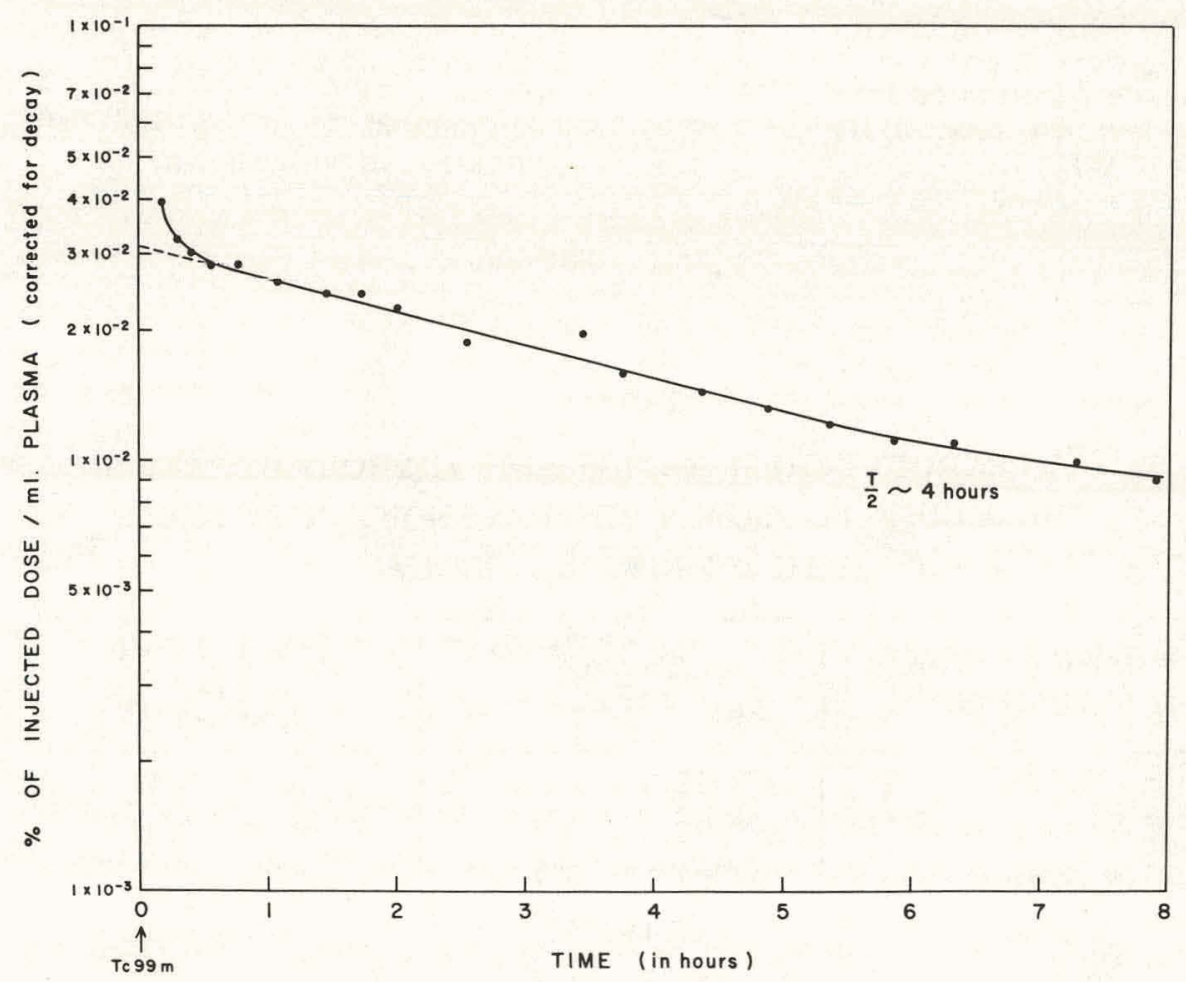

Figure 9. Plasma disappearance of $\mathrm{Tc}^{99 \mathrm{~m}}\left(\right.$ as $\left.\mathrm{TcO}_{4}{ }^{-}\right)$in a nephrectomized $14 \mathrm{~kg}$ dog. 
by L-thyroxine ${ }^{10}$ on the $\mathrm{Tc}^{99 \mathrm{~m}}$ uptake by the thyroid gland are shown in Table 2 . The thyroidserum ratio in a rabbit pretreated with $600 \mathrm{mg} \mathrm{NaClO}_{4}$ was 0.428 at 6 hours.

The thyroid uptake curve of $\mathrm{Tc}^{99 \mathrm{~m}}$ and its prompt wash out by $\mathrm{ClO}_{4}{ }^{-}$as seen in scans tend to support the thesis that $\mathrm{TcO}_{4}{ }^{-}$is not converted to an organic compound by the thyroid gland. ${ }^{3}$ The discharge of $\mathrm{Tc}^{99 \mathrm{~m}}$ from the human thyroid by perchlorate is shown in Figure 10, and Fig-

Table 2

EFFECT OF TSH AND THYROXINE (TSH SUPPRESSION)

ON THYRUID/SERUM RATIOS OF PERTECHNETATE

IN MICE ONE HOUR AFTER INTRAVENOUS

ADMINISTRATION

\begin{tabular}{ll|c}
\hline \multicolumn{2}{c|}{ Treatment } & Thyroid/serum ratio \\
\hline Control & (6 mice) & $80.5 \pm 28(\mathrm{SD})$ \\
TSH & (8 mice) & $56.3 \pm 12$ \\
L-thyroxine & (8 mice) & $49.2 \pm 20$ \\
\hline
\end{tabular}

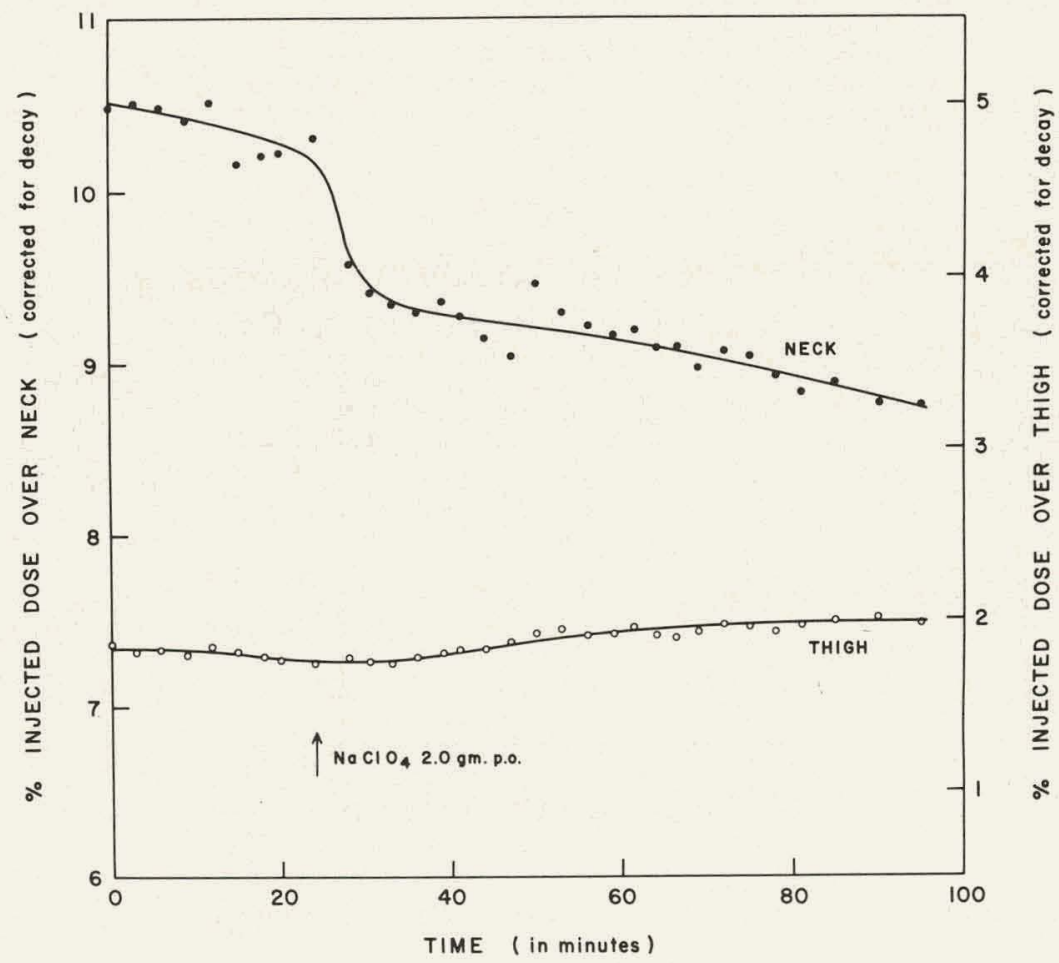

Figure 10. These curves were constructed from counts taken over the neck and thigh of a $51 \mathrm{~kg}$ female who received 1 $\mathrm{mc}$ of $\mathrm{Tc}^{99 \mathrm{M}_{4}}{ }^{-}$intravenously. $\mathrm{NaClO}_{4}$ produced a rapid discharge of the thyroid radioactivity (1 per cent of injected dose). The increasing high counts probably represent radioactivity discharged from the stomach by perchlorate. 
ure 11 shows the thyroid scan of a clinically euthyroid caucasian male made thirty minutes after the intravenous injection of $\mathrm{Tc}^{99 \mathrm{~m}}$. Gastric juice/serum and saliva/serum ratios are shown in Table 3 compared to iodide. Following an intravenous tracer dose the urinary and fecal excretion of $\mathrm{TcO}_{4}{ }^{-}$were studied in four patients and the results are summarized in Table 4.

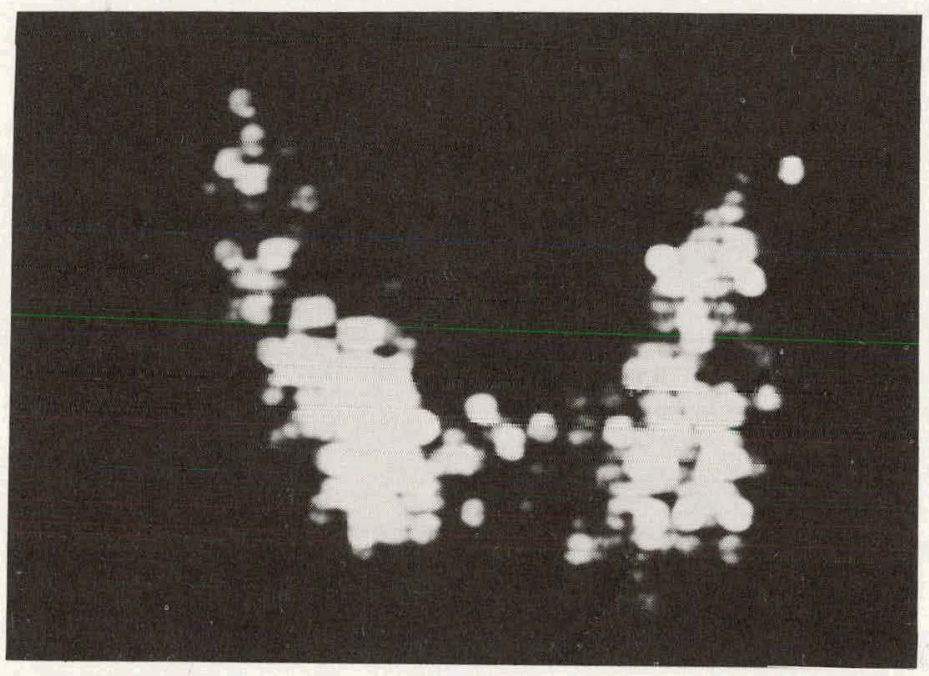

Figure 11. Thyroid scan in a clinically euthyroid caucasian male 30 minutes after $1.0 \mathrm{mc}$ of Tc $99 \mathrm{~m}$ intravenously.

Table 3

COMPARATIVE CONCENTRATION RANGES OF PERTECHNETATE AND IODIDE ${ }^{11}$

\begin{tabular}{l|c|c}
\hline & Pertechnetate & Iodide \\
\hline$\frac{\text { mixed saliva }}{\text { serum }}$ & $5-10$ & $15-30$ \\
$\frac{\text { gastric juice }}{\text { serum }}$ & $10-20$ & $10-30$ \\
$\frac{\text { thyroid }}{\text { serum }}$ & $20-100$ & $25-50$ \\
\hline
\end{tabular}

Saliva and gastric juice values are for human subjects. Thyroid values are for female CF No. 1 mice.

Figures 12, 13, and 14 show radiocardiograms on normal subjects following $440 \mu \mathrm{c}$ of $\mathrm{Tc}^{99 \mathrm{~m}}$ intravenously.

Table 5 shows comparative dose calculations for total body, stomach and thyroid following intravenous administration of $\mathrm{Tc}^{99 \mathrm{~m}}$ to a $70 \mathrm{~kg}$ man. A biological half-life of around 48 hours is assumed from the data in Table 4. The levels in the stomach and thyroid are assumed to follow the blood curve. Since a preparation of $\mathrm{Tc}^{99 \mathrm{~m}}$ which is retained within the vascular system would obviously be desirable, attempts were made to prepare tagged serum proteins 
Table 4

URINARY AND FECAL EXCRETION OF Tc ${ }^{99 m}$ IN MAN FOLLOWING

INTRAVENOUS INJECTION

\begin{tabular}{|c|c|c|c|c|}
\hline \multirow{2}{*}{$\begin{array}{l}\text { Hours after } \\
\text { injection }\end{array}$} & \multicolumn{4}{|c|}{ Per cent injected dose } \\
\hline & $\begin{array}{l}\text { (4 subjects) } \\
\text { urine }\end{array}$ & $\begin{array}{l}\text { (2 subjects) } \\
\text { feces }\end{array}$ & Total & $\begin{array}{c}\text { Cumulative } \\
\text { total }\end{array}$ \\
\hline $0-24$ & $\left(47^{36.7}\right.$ to 28.3$)$ & $\begin{array}{c}0.4 \\
\left(\begin{array}{cc}0.8 \text { to } & 0\end{array}\right)\end{array}$ & 37.1 & 37.1 \\
\hline $24-48$ & $\left(\begin{array}{r}7.7 \\
8.3 \text { to } 7.0)\end{array}\right.$ & 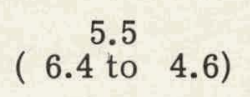 & 13.2 & 50.3 \\
\hline $48-72$ & 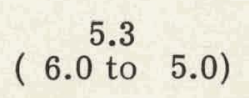 & $\begin{array}{l}13.1 \\
(15.8 \text { to } 10.4)\end{array}$ & 18.4 & 68.7 \\
\hline
\end{tabular}

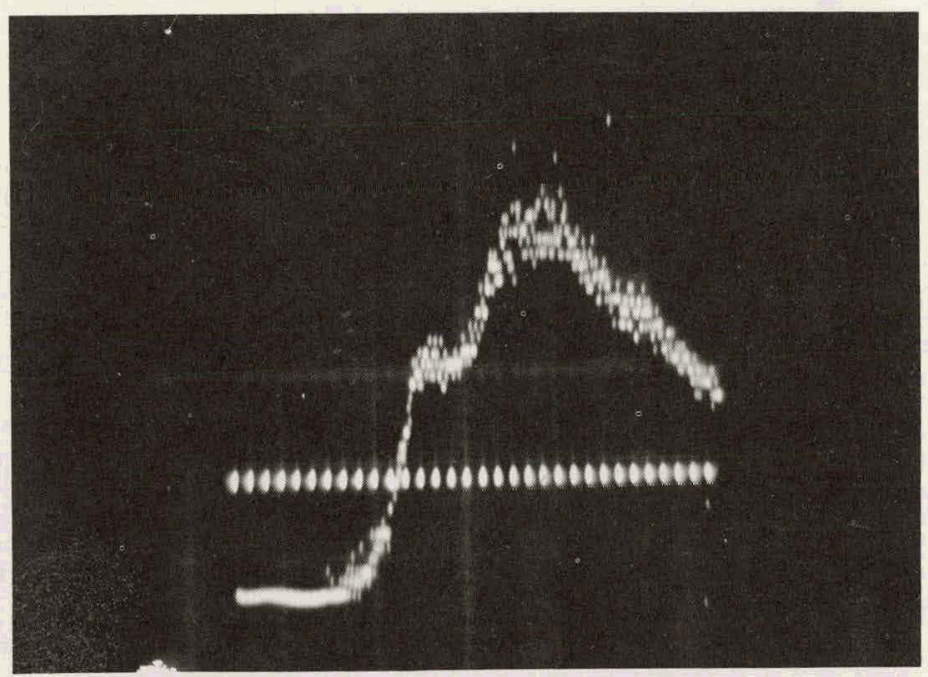

Figure 12. Record of radioactivity over precordium in normal negro male using apparatus described in text. Totalcurve (512 channels) represents 15 seconds ( 0.028 seconds/channel), with a maximum of 8000 counts per channel. The display is linear. Right heart, left heart and coronary peaks are clearly visible.

and tagged red cells by the process of incubation. These were uniformly unsuccessful using $\mathrm{TcO}_{4}{ }^{-}$. Similar experiments with $\mathrm{Tc}^{99 \mathrm{~m}}$ as $\mathrm{TcO}_{3}{ }^{-}$however show some promise.

\section{DISCUSSION}

From the point of view of radiation exposure and contamination, $\mathrm{Tc}^{99 \mathrm{~m}}$ appears to be an extremely safe tracer material, largely because of the ease of shielding and the half-life. These characteristics, together with its ready availability, make its general applicability feasible.

As a tool for studying thyroid function, $\mathrm{TcO}_{4}{ }^{-}$gives a measure of the trapping phase of io- 


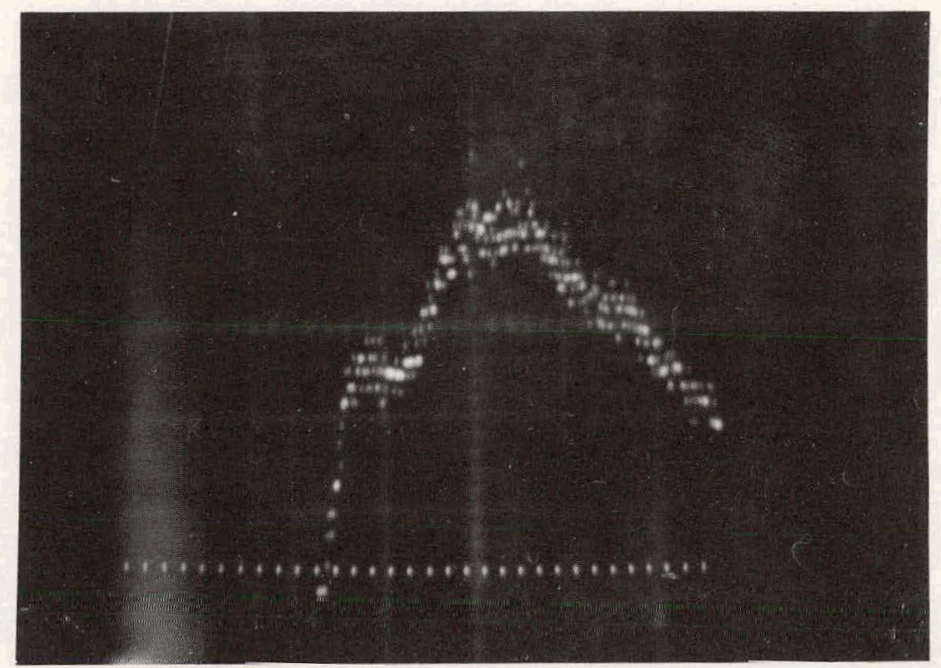

Figure 13. Logarithmic display of curve shown in Figure 12.

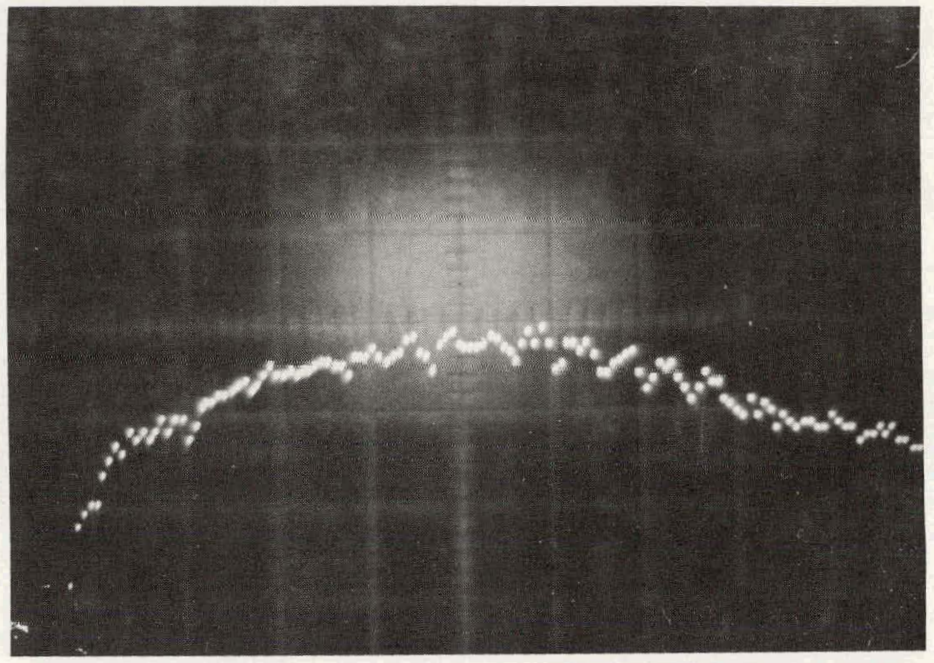

Figure 14. Record of a second subject with same isotope dosage as in Figure 12. Channel width -0.056 seconds. Note that individual heart beats are clearly visible.

dine metabolism. An almost immediate uptake in the gland of $1-2$ per cent of the injected dose gives excellent thyroid scans with a reduction in radiation dosage of a factor of 1000 or more. Although $\mathrm{Tc}^{99 \mathrm{~m}}$ localizes in the stomach and might conceivably be used for some type of cancer screening, the information obtainable from roentgenography and gastroscopy seems so superior that this type of application is unlikely. If its secretion in the stomach is by the neck chief cells, as in the case of iodide, it has little applicability in the study of acid formation. The diagnosis of Makel's diverticulum containing gastric mucosa should be possible. 
Table 5

\section{ABSORBED DOSE IN RATS FROM 1 MILLICURIE Tc ${ }^{99 \mathrm{~m}}$ GIVEN INTRAVENOUSLY TO $70 \mathrm{~kg}$ SUBJECT AS COMPARED TO USUAL DIAGNOSTIC DOSES OF $\mathrm{I}^{131}$}

\begin{tabular}{l|c|c|c}
\multicolumn{1}{c|}{ Agent } & Total body & Thyroid & Stomach \\
\hline $1 \mathrm{mc}$ & 0.014 & 0.025 & 0.26 \\
$\mathrm{Tc}^{99 \mathrm{~m}_{\mathrm{O}_{4}}}$ & & - & \\
$5 \mu \mathrm{r}$ & 0.014 & - & - \\
$\mathrm{I}^{131}$ tagged albumin & & & \\
$50 \mu \mathrm{c}$ & 0.06 & 100 & 1.5 \\
$\mathrm{I}^{131}$ iodide & & & \\
\hline
\end{tabular}

The science of radiocardiography has been for the most part, somewhat poorly developed. The availability of more sophisticated electronic equipment capable of handling 10,000 to 50,000 counts per second without significant loss and the development of memory units capable of processing such data without distortion, were among the factors which led us to explore the possibility of refining the technique of the isotope dye curve. At the time of writing it would seem that only the first pass through the heart is really useful because the rapid disappearance of $\mathrm{TcO}_{4}{ }^{-}$from the circulating blood makes the measurement of cardiac output by the usual methods unfeasible. Relative output measurements should be possible, however, using carefully controlled isotope injection and assuming that the conditions of measurement remain constant (blood volume, geometry, etc.). An agent retained in the blood stream would improve this situation substantially. The radiocardiograms presented above are the first results available. Considerable refinement should be possible even though, in this preliminary form there appears to be a substantial technical improvement over existing methods.

\section{SUMMARY AND CONCLUSIONS}

Investigation of the metabolism of technetium $-99^{\mathrm{m}}$ administered intravenously to humans and experimental animals as $\mathrm{TcO}_{4}{ }^{-}$reveals that the administered material is probably diluted at first in the extracellular space, and later slowly penetrates into the intracellular space. About one per cent of the injected dose localizes in the thyroid gland and about 25 per cent in the stomach. The localization is inhibited by $\mathrm{I}^{-}$and $\mathrm{ClO}_{4}{ }^{-}$. About one-half the injected material is excreted by human subjects in 48 hours. The short half-life (six hours), ready availability, and desirable radiation characteristics, make possible applications in thyroid scanning and radiocardiography, with greatly reduced radiation dosage to the patient.

\section{LITERATURE CITED}

1. Tucker, W. P., M. W. Greene, A. J. Weiss, and A. Murrenhoff. BNL-3746, 1958.

2. Anders, E. NAS - NS:021. Office of Technical Services, Department of Commerce, Washington 25 , D. C. 
3. Pitt-Rivers, R., and J. R. Tata. The Thyroid Hormones, New York: Pergamon Press, 1959, p. 37.

4. Wallace-Durbin, P. J. Dental Research, 33:789, 1954.

5. Aabar, M., S. Guttman, and Z. Lewitus. Intern. J. Appl. Radiation and Isotopes, 7:87, 1959.

6. Wollman, S. H. Am. J. Physiol., 186:453, 1956.

7. Brown-Grant, K. Physiol. Rev., 41:189, 1961.

8. Vanderlaan, J. E., and W. P. Vanderlaan. Endocrinology, 40:413, 1947.

9. Malmi, N. S., D. K. Granner, D. J. Dongleman, B. H. Petcrs, and G. Muller. Endocrinology, 67:70, 1960 .

10. McKenzie, J. M. Endocrinology, 63:372, 1958.

1.1. Pitt-Rivers, R., and J. R. Tata. The Thyroid Hormones, New York: Pergamon Press, 1959, p. 127. 


\title{
EFFECT OF RNA AND YEAST AUTOLYSATE ON EXPERIMENTAL INFECTION IN IRRADIATED AND UNIRRADIATED MICE ${ }^{*}$
}

By

\author{
C. W. Hammond, ${ }^{\ddagger}$ S. K. Anderle, and C. P. Miller
}

Detre and Finch ${ }^{1}$ found a marked reduction in mortality (30 days) from a lethal dose of $\mathrm{X}$ radiation in mice injected intraperitoneally or intravenously with yeast ribonucleic acid (RNA) or yeast autolysate 30 minutes before exposure. The following experiments were undertaken to determine whether this protective effect might have been due, in part at least, to increased resistance to bacterial infection, since the development of endogenous infection plays a significant role in the death of mice exposed to mid-lethal doses of ionizing radiation. ${ }^{2,3}$ Mice were accordingly treated with RNA or yeast autolysate 24 hours or 30 minutes before, or on the fourth day after irradiation $(475 \mathrm{r}$ ) and challenged on the fifth day post-irradiation by intraperitoneal inoculation with Pseudomonas aeruginosa.

\section{MATERIALS AND METHODS}

Mice. Ten-week old CF No. 1 females were housed in stainless steel cages and supplied with feed and water ad libitum. Water bottles were sterilized daily and cages weekly. All mice in an experiment came from the same shipment.

Irradiation $(475 \mathrm{r}$ ) was delivered by a $250 \mathrm{kv}, 30$ ma Maxitron (G.E.) machine using 0.25 $\mathrm{mm} \mathrm{Cu}$ and $1 \mathrm{~mm} \mathrm{Al} \mathrm{filters} \mathrm{at} \mathrm{a} \mathrm{target} \mathrm{distance} \mathrm{of} 70 \mathrm{~cm}$ and a dose rate of approximately $60 \mathrm{r}$ per min. For details of the method of exposure see Hammond et al. ${ }^{4}$

Injections. 24 hours or 30 minutes before irradiation or on the fourth day after irradiation, mice were injected intraperitoneally or intravenously with $1.0 \mathrm{ml}$ of a 2 per cent solution of RNA (Schwarz Lab., Inc., Mt. Vernon, N. Y.) or intraperitoneally with $0.5 \mathrm{ml}$ of a 20 per cent solution of yeast autolysate (Albimi Lab., Inc., Brooklyn, N. Y.). RNA was dissolved in N/25 $\mathrm{NaOH}$ and adjusted to $\mathrm{pH}$ 7.2. It was not autoclaved routinely, but only as noted in specified experiments. Yeast autolysate was dissolved in buffered saline and autoclaved at $15 \mathrm{lbs}$ for 15 minutes. It was too toxic to be administered intravenously. Intraperitoneal injection caused moderately severe prostration for 15 or 20 minutes, most marked in irradiated mice. Control mice were injected with buffered saline.

Challenge. On the fifth day post-irradiation, mice were randomly distributed to separate cage mates and challenged by intraperitoneal injection of graded inocula of a streptomycin resistant strain of Ps. aeruginosa, used for a number of years in this laboratory to determine the effect of irradiation on susceptibility to bacterial infection. ${ }^{5-8}$ This microorganism was chosen because the infection it produces is rapidly fatal in susceptible animals; i.e., inoculated mice

\footnotetext{
* * This paper appears in Proc Soc. Exptl. 3 (mar.

*This paper appears in Proc. Soc. Exptl. Biol: and Med., 109:690 $\wedge^{-3} 1962$ )

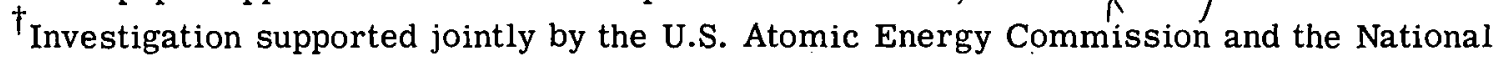
Institutes of Health.

${ }^{\ddagger}$ Present address: Department of Microbiology, University of Illinois School of Medicine, Chicago 12, Illinois.
} 
either die within 18-36 hours or survive the observation period of 30 days. Virulence has been maintained by weekly passage in CF No. 1 mice. An 18-hour culture was washed off an agar plate in $5 \mathrm{ml}$ saline, and any clumps of bacteria were dispersed by shaking in an Erlenmeyer flask containing a few glass beads on an electric rotator for 15 minutes. The suspension was made up to contain $10^{9}$ bacteria/ml by means of a Coleman spectrophotometer and then diluted to provide the desired inocula. Irradiated mice were inoculated with approximately $10^{8}, 2 \times 10^{7}$, and $10^{7}$ microorganisms in $0.5 \mathrm{ml}$ volume, 10 mice per inoculum. Actual numbers of bacteria inoculated were determined from quadruplicate platings of appropriate dilutions of the suspension used. $L D_{50}$ 's were calculated by probit analysis.

Unirradiated mice were inoculated with somewhat larger numbers of Ps. aeruginosa. (See Table 1).

Table 1

MORTALITIES AMONG UNIRRADIATED MICE TREATED WITH RNA OR YEAST AUTOLYSATE (YA) BEFORE CHALLENGE WITH PS. AERUGINOSA.

\begin{tabular}{|c|c|c|c|c|c|c|c|c|}
\hline \multirow{4}{*}{$\underset{\text { Inocula }}{\text { Mean }}$} & \multicolumn{8}{|c|}{ Time of treatment before challenge } \\
\hline & \multicolumn{4}{|c|}{ 4-5 days } & \multicolumn{4}{|c|}{24 hours } \\
\hline & \multicolumn{3}{|c|}{ Per cent mortality } & \multirow{2}{*}{$\begin{array}{l}\text { No. } \\
\text { Mice }\end{array}$} & \multicolumn{3}{|c|}{ Per cent mortality } & \multirow{2}{*}{$\begin{array}{l}\text { No. } \\
\text { Mice }\end{array}$} \\
\hline & RNA & YA & Controls & & RNA & YA & Controls & \\
\hline \multicolumn{9}{|c|}{ Treatment i.p. } \\
\hline $2.3 \times 10^{8}$ & 18 & 20 & 67 & 240 & 20 & 27 & 50 & 120 \\
\hline $1.9 \times 10^{8}$ & 2 & 12 & 40 & 240 & 2 & 12 & 27 & 120 \\
\hline $3.8 \times 10^{7}$ & 0 & 5 & 1 & 240 & 0 & 5 & 5 & 120 \\
\hline \multicolumn{9}{|c|}{ Treatment i.v. } \\
\hline $1.6 \times 10^{8}$ & 23 & - & 53 & 60 & 25 & - & 55 & 60 \\
\hline $1.3 \times 10^{8}$ & 20 & - & 50 & 60 & 20 & - & 45 & 60 \\
\hline $2.6 \times 10^{7}$ & 0 & - & 0 & 60 & 0 & - & 10 & 60 \\
\hline
\end{tabular}

Ps. aeruginosa. The other two inocula in each instance contained respectively $5 / 6$ and $1 / 6$ of that number. Each inoculum was given to 10 mice.

\section{RESULTS}

Irradiated mice. In all four challenge experiments summarized in Figure 1, mice treated intraperitoneally with RNA before or after irradiation had higher $L D_{50}$ 's than their controls, indicating increased resistance to the experimental bacterial infection. The increase was greatest in those treated the fourth day. post-irradiation-one day before challenge.

Similar results (not included in Figure 1) were obtained in mice treated intraperitoneally with yeast autolysate 24 hours or 30 minutes before irradiation, but not in those treated the fourth day post-irradiation, presumably because the latter had not yet recovered from the toxic effect of yeast autolysate when they were challenged on the following day.

Intravenous treatment with RNA 24 hours before or on the fourth da.y.after irradiation in- 
creased $\mathrm{LD}_{50}$ 's of the challenge inoculation almost, but not quite as much as intraperitoneal treatment shown in Figure 1.

Unirradiated mice. Results of a series of experiments summarized in Table 1 showed that treatment with RNA or yeast autolysate reduced mortality from the experimental infection in unirradiated mice. The reduction was most marked in mice treated intraperitoneally with RNA 4 or 5 days before challenge. Some effect resulted from intravenous treatment with RNA. Yeast autolysate injected intraperitoneally also reduced mortality, particularly when given 4 or 5 days before challenge.

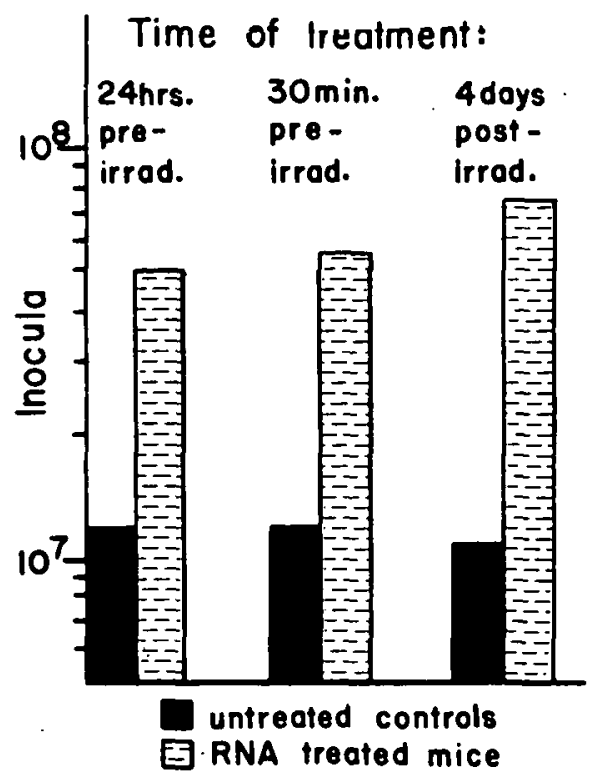

Figure 1. LD 50 's of Ps. aeruginosa in mice inoculated on the fifth day post-irradiation $(475 \mathrm{r}$ ). Treated mice received $20 \mathrm{mg}$ RNA intraperitoneally at times indicated.

Effect of autoclaving on activity of RNA. In three experiments, the relative effectiveness of autoclaved (15 lbs for 15 minutes) and unautoclaved RNA was compared in mice treated the fourth day post-irradiation and challenged the following day. In each instance, autoclaved RNA was somewhat more effective than unautoclaved in reducing mortality from the experimental infection.

\section{DISCUSSION}

No explanation can be offered at this time for the increased resistance to experimental infection with Ps. aeruginosa in irradiated and unirradiated mice. The effect of treatment with RNA and yeast autolysate may have been due to non-specific increase in host resistance. In this connection, it should be noted that Smith, Smith and Alderman ${ }^{9}$ found that intraperitoneal or subcutaneous injection of finely ground glass or other inorganic particles, within a few hours after ir radiation reduced the mortalities of mice challenged with Proteus vulgaris or Pseudomonas aeruginosa. The protective activity was attributed to the resulting inflammatory reaction. 
In the experiments reported here, however, RNA and yeast autolysate or their breakdown products may possibly have played a more specific role. Taliaferro and Jaroslow ${ }^{10}$ found that injection of DNA partially degraded in vitro restored to a considerable degree the ability of rabbits to produce hemolysins.

Whatever interpretation of our results will ultimately seem appropriate, they nevertheless suggest a possible explanation of the findings of Detre and $\mathrm{Finch}^{1} \mathrm{cited}$ in the introduction.

The authors are indebted to Dr. Leon O. Jacobson, Director of the Argonne Cancer Research Hospital for use of its X-ray facilities, and to James Bland for irradiating the mice.

\section{LITERATURE CITED}

1. Detre, K. D., and S. C. Finch. Science, 128:656, 1958.

2. Miller, C. P., C. W. Hammond, and M. Tompkins. J. Lab. and Clin. Med., 38:331, 1951.

3. Miller, C. P., C. W. Hammond, M. Tompkins, and G. Shorter. J. Lab. ānủ Člin. Med., 39: $462,1952$.

4. Hammond, C. W., D. Ruml, D. B. Cuuper, and C. P. Miller. J. Exptl. Med., 102:403, 1955.

5. Hammond, C. W., S. K. Anderle, and C. P. Miller. Radiation Research, 11:242, 1959.

6. Miller, C. P., C. W. Hammond, and S. K. Anderle. J. Exptl. Med., 111:773, 1960.

7. Hammond, C. W., S. K. Anderle, and C. P. Miller. Proc. Soc. Exptl. Biol. and Med., 104: 261,1960 .

8. Hammond, C. W., S. K. Anderle, and C. P. Miller. Proc. Soc. Exptl. Biol. Med., 105:1, 1960.

9. Smith, W. W., F. Smith, and I. M. Alderman. Am. J. Physiol., 182:400, 1955.

10. Taliaferro, W. H., and B. N. Jaroslow. J. Infect. Dis., 107:341, 1961. 


\section{MODIEICATION OF THE RADIATION EFFECT ON HAIR_ROOTS OF THE MOUSE BY ACTINOMYCIN D* \\ By}

M. L. Griem and K. Ranniger ${ }^{\dagger}$

Various chemical and physical agents can be used to modify the radiation response in tissue. ${ }^{1-3}$ Several reports have emphasized the impurlance of the time relationship between administration of radiation modifiers and $x$-rays. ${ }^{4-6}$

The observation that radiation induces distinct morphological changes in human and other mammalian hairs ${ }^{7}$ has provided a useful device for screening such modifying agents in rodents. Telogen or resting hairs are mitotically inactive and relatively insensitive to radiation ${ }^{8}$ while hairs in the anagen or growing stage are mitotically active and highly radiosensitive. Irradiation of anagen hairs results in atrophy of the hair bulb and in dysplastic changes characterized by irregularity and destruction of the hair shaft, the number of dysplastic hairs so produced being related to the dose of radiation. Some chemical agents produce similar changes in anagen hair.

This experimental model lends itself to statistical analysis and we have used it to investigate the role played by Actinomycin $\mathrm{D}$ when given in conjunction with radiation. Insofar as the cells in the hair indicator system are in an actively mitotic state they may be used to give some indication of altered radiosensitivity that might be expected in other actively mitotic cells, as for example those of a malignant tumor. As in previous work of a similar nature, our chief interest lay in the therapeutic implications of the altered radiosensitivity produced in certain malignancies by prior administration of Actinomycin D.

\section{METHODS}

The growth cycle of hair in the mouse lasts for 17 to 20 days from the earliest anagen to the onset of telogen. ${ }^{6}$ Hair in the resting state is easily removed by plucking, while growing hairs are extremely difficult to pluck. We therefore discarded all those mice with actively growing hair, thus insuring that hairs to be examined later would all be in the same stage of development when treated and again when examined.

Ten days before irradiation, both haunches of the mice (CF No. 1 females) were plucked. About 8 days later, at intervals of $48,36,24,16,8,4,2$ and 1 hours before irradiation different groups of animals were given single intraperitoneal injections of Actinomycin $D$, the dosage being either at the rate of $100 \mu \mathrm{g} / \mathrm{kg}$ or $150 \mu \mathrm{g} / \mathrm{kg}$.

The right haunch of each mouse was then exposed to a single dose of 400 rads of $x$-rays using a Machlett OEG 60 tube operated at $50 \mathrm{kv}$ and $30 \mathrm{ma}$ with $2 \mathrm{~mm}$ added A1 filtration, a 2$\mathrm{cm}$ cone and a focal skin distance of $11 \mathrm{~cm}$. This produces a depth dose of 50 per cent in tissue at $1.2 \mathrm{~cm}$. The left haunch was not irradiated and served as a control on the action of Actinomycin $D$ alone.

\footnotetext{
*Abbreviated version of a paper which appeared in Radiation Research 17:92 1962 )

${ }^{\dagger}$ Department of Radiology, University of Chicago. .
} 
The number of dysplastic hairs produced reaches its maximum 3 days after irradiation. At this time, therefore, the newly growing hairs were plucked, floated on a film of water in a Petri dish scored with a grid on its base, and examined under a binocular dissecting microscope by transmitted blue light. Except where otherwise specified 50 hairs from each haunch were examined. (The experimental setup is illustrated in Table 1.)

Table 1

GENERAL SCHEME OF THE EXPERIMENTS

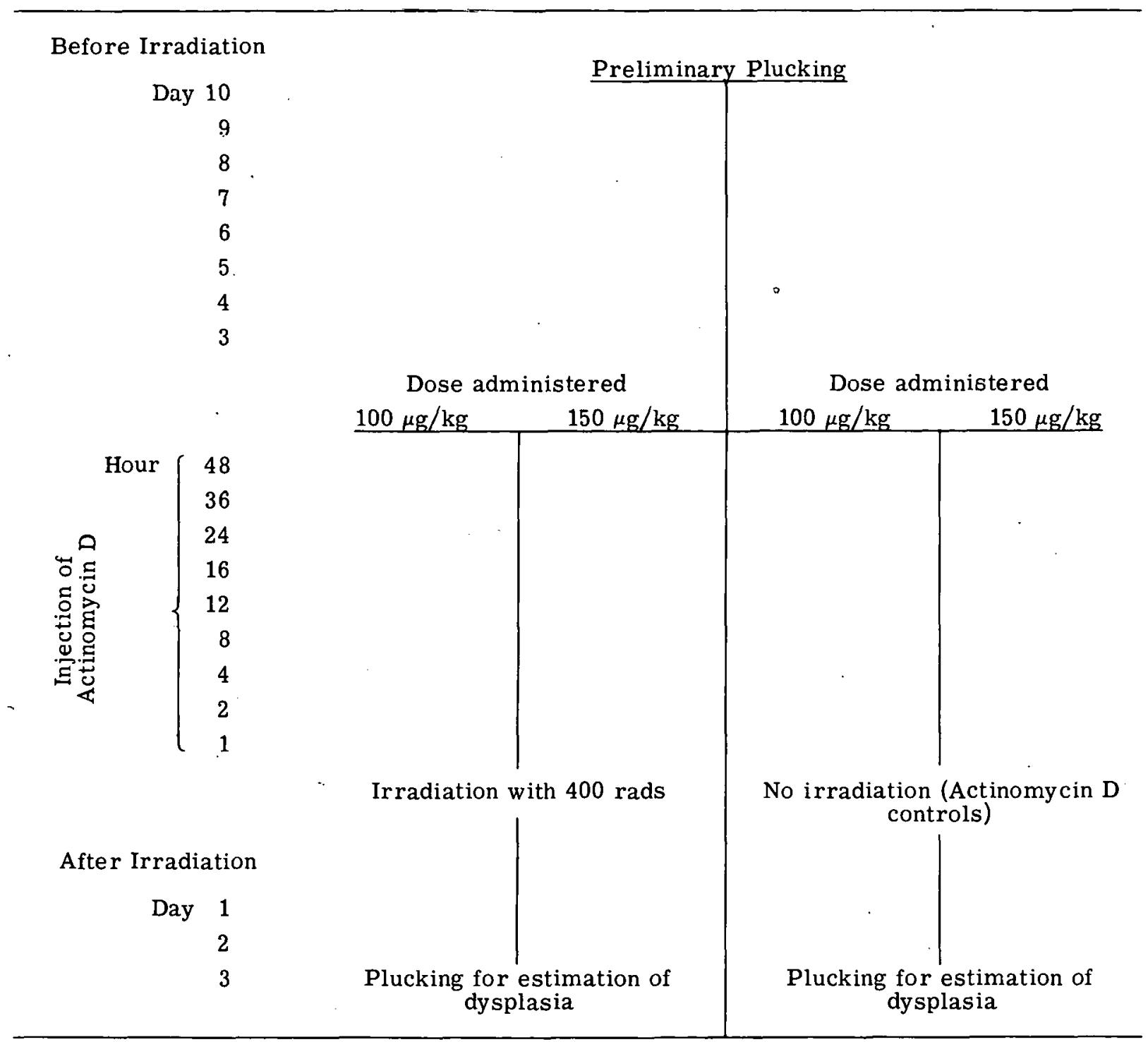

Precautions to eliminate observer bias in counting of hairs, as well as any possible cage effect, were taken by caging animals from all different treatment groups together, and completing all counts from one cage at the same time. Thus the experiment had the form of a randomized block. The data were subjected to the appropriate analys is of variance which revealed no 
significant variation due to method of counting or caging. ${ }^{9}$ Histologic preparations of the skin similar to those prepared by Geary ${ }^{8}$ were beyond the scope of this investigation. Furthermore, Geary's results tend to show that histologic changes in the skin are associated with the formation of dysplastic hairs.

\section{RESULTS}

Figure 1 shows the reproducible sigmoid curve obtained in our earlier studies, ${ }^{6}$ and represents the effect of graded doses of radiation (200 to $900 \mathrm{r}$ ) on the production of dysplastic hair. Five animals were evaluated per point and 100 hairs counted per animal. The vertical lines represent the standard deviation.

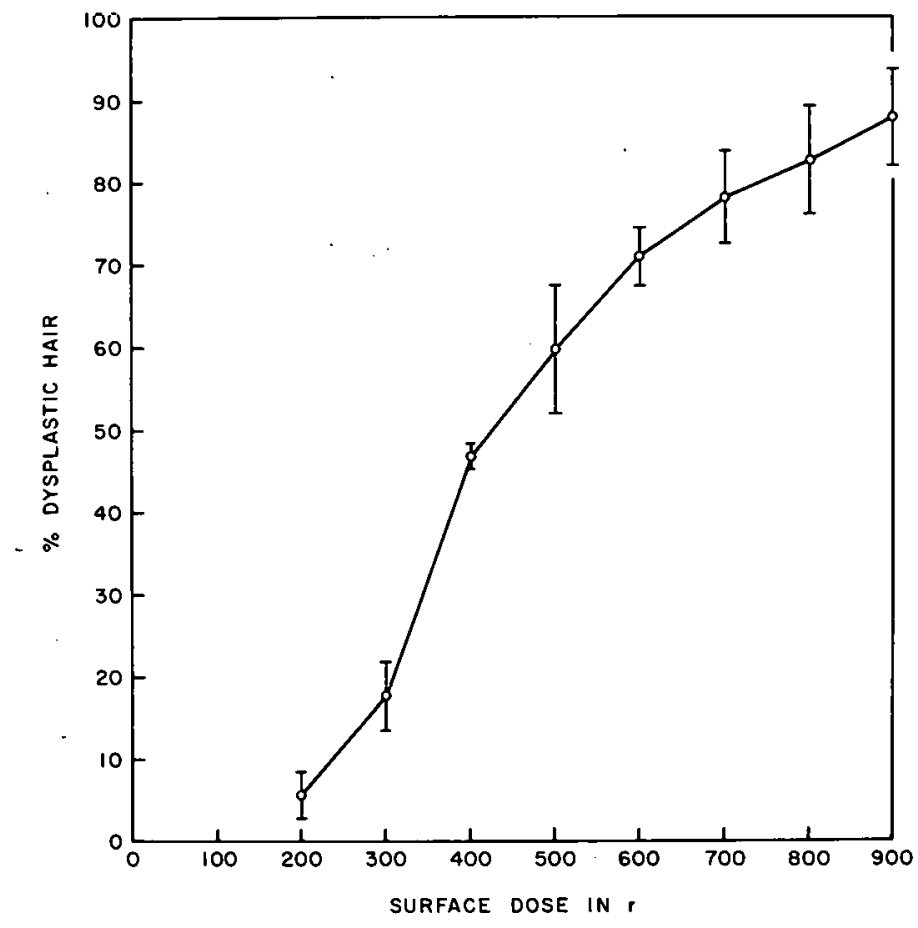

Figure 1. Production of dysplastic hair by $x$-radiation. (Figure 1 reproduced by courtesy of the publishers of Radiology, Detroit, Michigan.)

Figure 2 illustrates the effect of graded single doses of Actinomycin D alone (50 to $800 \mu \mathrm{g} /$ $\mathrm{kg}$ ) on the production of dysplastic hairs. Nine animals were evaluated per point and 50 hairs per animal. Counts were made 3 days after intraperitoneal injection of the drug.

Examination of hairs from the non-irradiated (Actinomycin D controls) haunches showed no dysplasia in over 75 per cent of the animals in all treatment groups $(100 \mu \mathrm{g} / \mathrm{kg}$ or $150 \mu \mathrm{g} / \mathrm{kg} \mathrm{Ac}-$ tinomycin $\mathrm{D}$ injected 8 to 10 days after initial plucking and examined 3 days later). The remaining 25 per cent were found to have no more than 1 dysplastic hair per 50 hairs counted.

Figure 3 illustrates the percentage of dysplastic hairs produced when a single surface dose of $400 \mathrm{rads}$ follows intraperitoneal injection of $100 \mu \mathrm{g} / \mathrm{kg}$ of Actinomycin D at varying time inter- 


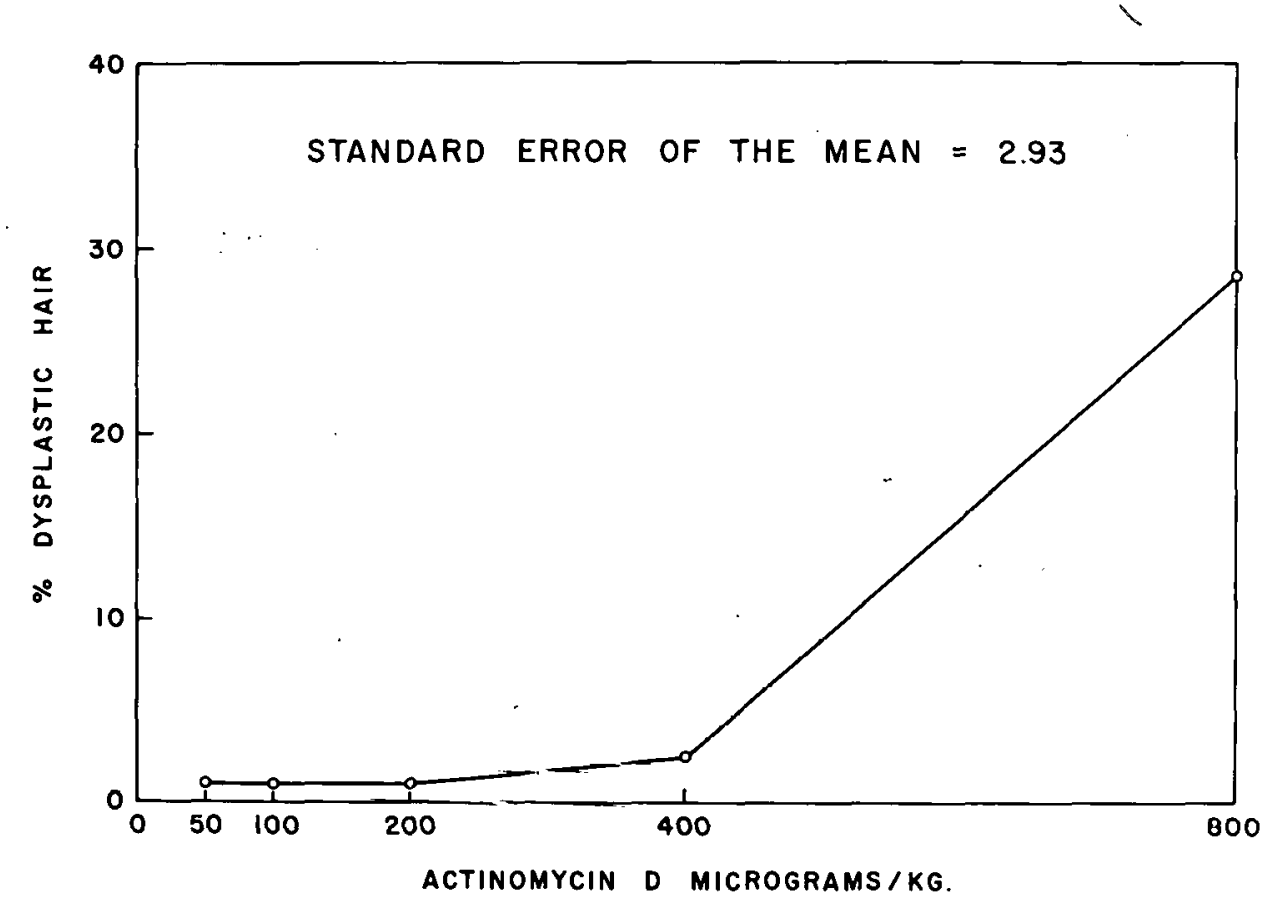

Figure 2. Production of dysplastic hair by intraperitoneal administration of Actinomycin D.

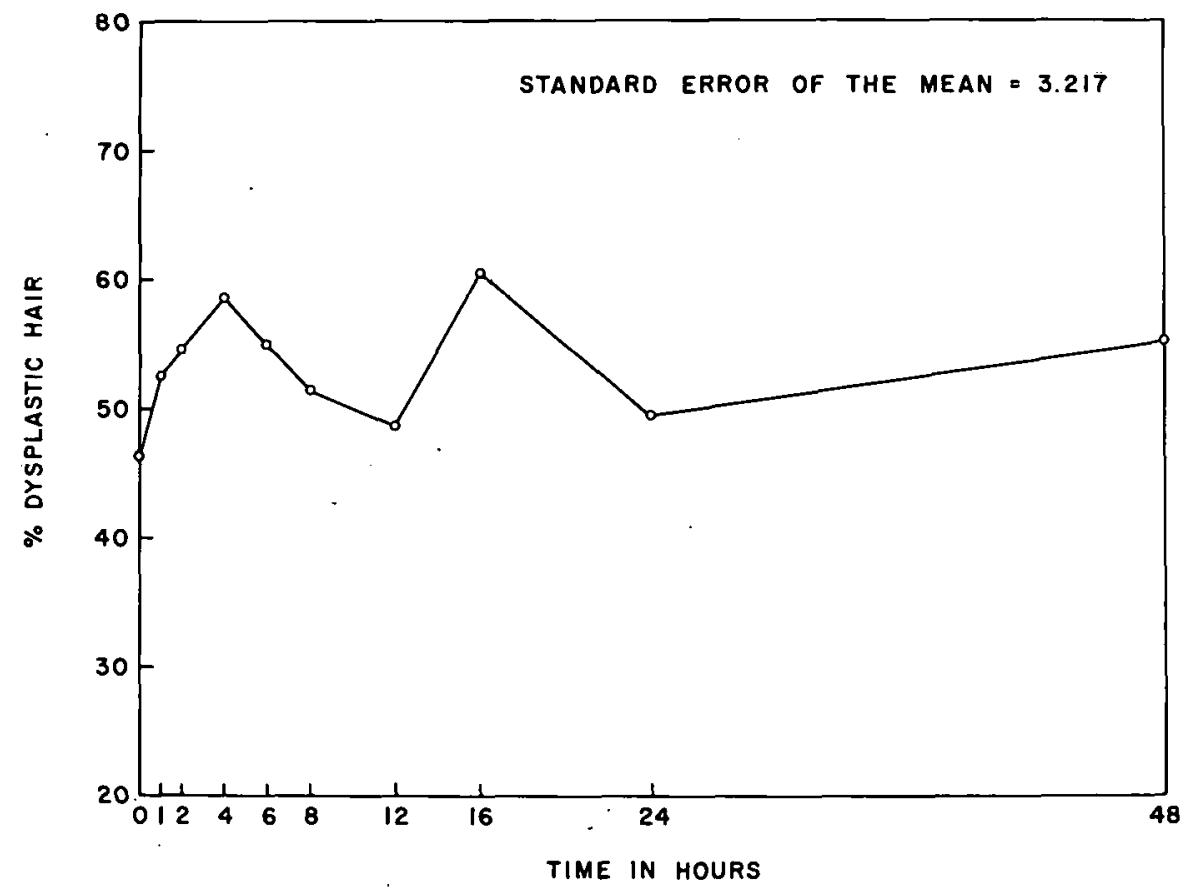

Figure 3. Effect of variation of time interval between administration of $100 \mu \mathrm{g} / \mathrm{kg}$ of Actinomycin D and subsequent radiation with $400 \mathrm{r}$ on the production of dysplastic hair. 
vals. (The point on the ordinate represents the effect of irradiation with 400 rads alone.) Six animals were examined and 50 hairs per animal were counted. Essentially the same figures were obtained when 10 animals were examined and 50 hairs per animal were counted. Figure 4 illus trates the results obtained when the dose of Actinomycin D was increased to $150 \mu \mathrm{g} / \mathrm{kg}$ ( 6 animals per point and 50 hairs per animal). The standard error of the mean is given on each figure.

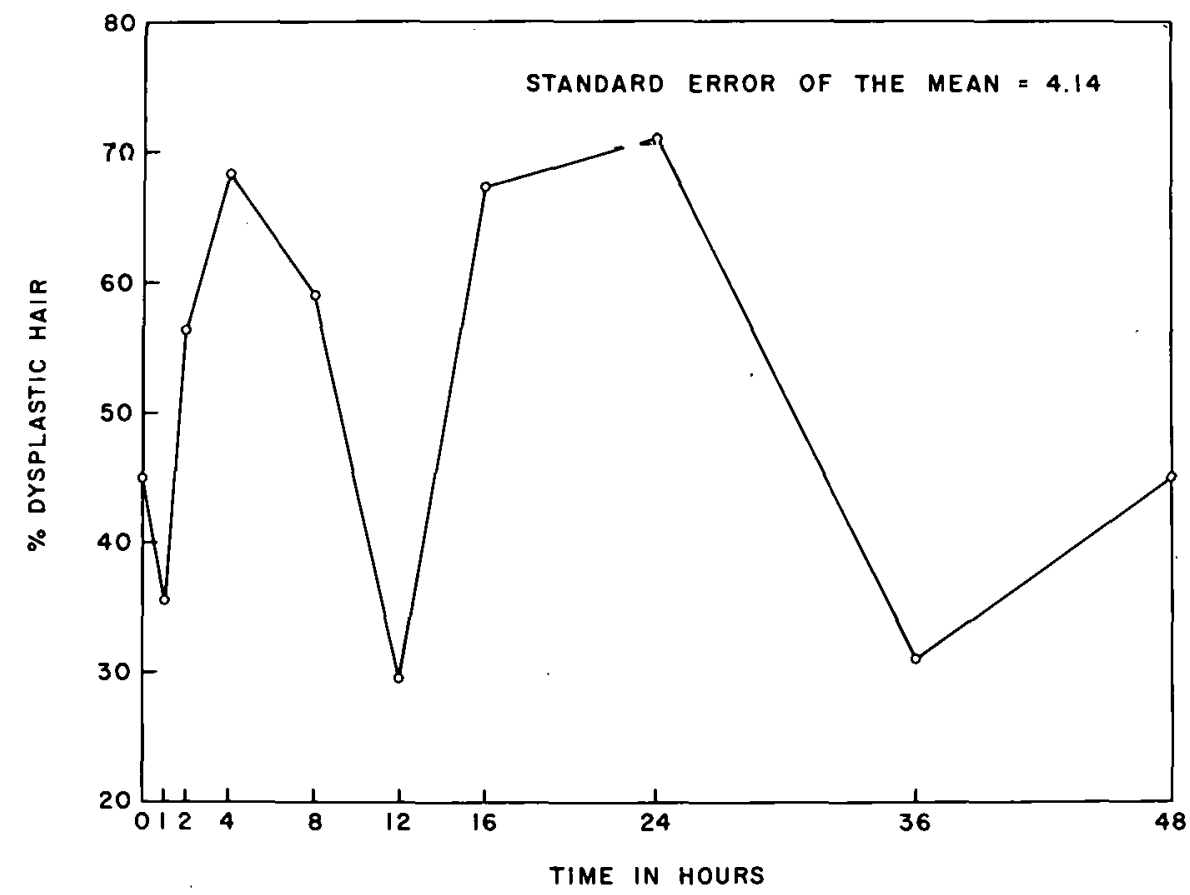

Figure 4. Similar experiment using $150 \mu \mathrm{g} / \mathrm{kg}$ of Actinomycin $\mathrm{D}$ and subsequent radiation with $400 \mathrm{r}$.

\section{DISCUSSION}

A number of reports have described the combined use of Actinomycin $\mathrm{D}$ and radiation in the treatment of animal tumors and human malignancies in vivo and in vitro. ${ }^{10-15}$ Different techniques have been used and so far the results have been equivocal. No previous attempt however, has been made to examine the effect produced by varying the time interval between drug administration and subsequent irradiation.

Figure 3 demonstrates significant synergism when $x$-rays follow Actinomycin $(100 \mu \mathrm{g} / \mathrm{kg})$ at intervals of 4 and 16 hours. Actinomycin $D$ alone at a dose twice that used in the combination treatment does not increase the production of dysplastic hair. Figure 4 suggests that increasing the dose of the drug to $150 \mu \mathrm{g} / \mathrm{kg}$ may inhibit damage to hairs irradiated 1,12 , and 36 hours later, and this observation, which was unexpected, is being investigated further. Statistical analysis of the data upon which Figure 4 is based supports the concept that the degree of inhibition is real.

The most difficult problem faced by investigators, namely the lack of a suitable biological indicator system for preliminary observations on the combined effects of drug and $x$-rays for comparison with the effects of either agent alone, seems to have been solved satisfactorily by 
the method described above. Our findings indicate that Actinomycin D exerts a synergistic effect on the atrophy and dysplasia induced in the hair matrix by irradiation at 4 and 16 hours after the administration of the drug. It further appears that an increased dose of Actinomycin may protect against radiation administered 1,12 , and 36 hours later.

The mechanism of this cyclic response is currently under study. Hackmann ${ }^{16}$ found that Actinomycin $C$ produced an increased number of mitoses 1 and 5 hours after administration of 2 to $5 \mu \mathrm{g}$ of drug to mice. From 5 to 22 hours after drug injection he observed a decrease in mitoses followed by a return to normal after 22 hours.

\section{ACKNOWLEDGMENTS}

The authors wish to thank Professor Paul Meier and Mr. Jack Marshal of the Department of Statistics for their constructive criticism of the statistical interpretations of this work.

\section{LITERATURE CITED}

1. Kaplan, H. S. Am. J. Roentgenol. Radium Therapy Nuclear Med., 80:822, 1958.

2. Andrews, J. R., and S. E. Sneider. Am. J. Roentgenol. Radium Therapy Nuclear Med., 81: $485,1959$.

3. Selawry, O. S., J. C. Carlson, and G. E. Moore. Am. J. Roentgenol. Radium Therapy Nuclear Med., 80:833, 1958.

4. Ranniger, K., and M. L. Griem. Radiation Res., 12:465, 1960.

5. Rothe, W. E., and M. M. Grenan. Science, 133:888, 1961.

6. Griem, M. L., F. D. Malkinson, and P. H. Morse. Radiology, 77:486, 1961.

7. Van Scott, E. J., and R. P. Reinertson. J. Invest. Dermatology, 29:205, 1957.

8. Geary, J. R., Jr. Am. J. Anat., 91:51, 1952.

9. Snedecor, G. W. Statistical Methods, 4th Ed., Ames, Ia.: Iowa State College Press, 1955, ch. 10.

10. Bases, R. E. Cancer Res., 19:1223, 1959.

11. Chen, P. Y., and E. J. Liebnev. Radiology, 76:273, 1961.

12. D'Angio, G. J., S. Farber, and C. L. Maddock. Radiology, 73:175, 1959.

13. Maddock, C. L., G. J. D'Angio, S. Farber, and A. H. Handler. Ann. N. Y. Acad. Sci., 89: 386,1960 .

14. Farber, S., G. J. D'Angio, A. Evans, and A. Mitus. Ann. N. Y. Acad. Sci., 89:421, 1960.

15. Tan, C. T. C., R. B. Gobbey, C. L. Yap, N. Wollner, C. A. Hackethal, L. M. Murphy, H. W. Dargeon, and J. H. Burchenal. Ann. N. Y. Acad. Sci., 89:426, 1960.

16. Hackmann, C. Z. Krebsforsch, 58:607, 1952. 


\section{MODIFICATION OF RADLATION RESPONSE OF TISSUE BY COLCHICINE 。 PRELIMINARY CLINICAL EVALUATION* \\ By}

M. L. Griem and F. D. Malkinson ${ }^{\dagger}$

Initial experimental studies combining parenteral colchicine and irradiation were conducted on mice using a microscopic hair indicator system to evaluate the extent of cellular damage to the anagen hair matrix induced by the combined use of colchicine and irradiation. The parameter of time interval between injections of the drug and irradtation ${ }^{1,2}$ was studied in detail. These experiments showed that an interval of 16 hours between drug administration and irradiation produced the maximum degree of dysplasia in the hair. Similar experiments were then conducted using solid transplantable mouse tumors. Subsequently, patients with advanced malignancies were studied, employing usual palliative doses of radiation therapy up to a total of between 2000 and 4000 rads. Patients were given intravenous injections of $4 \mathrm{mg}$ of colchicine, followed after 16 hours by a $500 \mathrm{rad}$ minimum dose delivered to the tumor. This sequence was repeated twice weekly for 2 to 4 weeks.

Fifty patients with advanced malignancies were treated. Table 1 shows the primary site of the tumor and the extent of disease. All cases were considered inoperable, and all had proven histologic diagnosis as shown in Column 2. The number of cases is listed in Column 3. Column 4 shows the objective response based on physical or $\mathrm{x}$-ray examination as determined at least one month or more after treatment.

Most gratifying response was obtained in adenocarcinoma of the stomach, pancreas, colon and lung. Favorable results were also obtained in treated skin sites in patients with mycosis fungoides, squamous cell carcinoma and melanoma of the skin. The undifferentiated carcinoma of the lung tumors treated seemed to respond; but in these patients, death resulted from occult metastases untreated by radiation. No significant response. was obtained in renal cell carcinoma of the kidney.

There are patients in the objective response group who have survived for six to twenty months without evidence of recurrence of the primary lesion or metastases; however, the observation period is still too short for a critical comparison of this group with a control series treated with $\mathrm{x}$-ray alone. Toxic manifestations characteristic of colchicine have not been a problem. Transitory leukopenia of two days duration sometimes occurs, but diarrhea and hair loss were not observed.

Studies by Walaszek and co-workers ${ }^{3}$ on the parenteral distribution of radioactive colchicine suggest that this drug is preferentially retained in tumors and in the gastrointestinal tract; this may explain the observed response of adenocarcinoma of the gastrointestinal origin.

\footnotetext{
*This paper was presented at the 8th International Cancer Congress, Moscow, U.S.S.R., July, 1962, and will appear in the proceedings of the conference.

$\dagger_{\text {Department }}$ of Medicine (Dermatology), University of Chicago, Chicago, Illinois, U.S.A. This work was supported in part by Public Health Service Research Grant \#E-1444 C6.
} 
Table 1

\begin{tabular}{|c|c|c|c|c|}
\hline Site & Histology & No. of cases & $\begin{array}{l}\text { No. of objective } \\
\text { responses }\end{array}$ & \\
\hline $\begin{array}{l}\text { Colon with } \\
\text { pelvic metastases }\end{array}$ & Adenocarcinoma & 10 & 8 & \\
\hline $\begin{array}{l}\text { Stomach with } \\
\text { metastases }\end{array}$ & Adenocarcinoma & 3 & 3 & \\
\hline Lung & Squamous & 1 & 0 & \\
\hline Lung & Adenocarcinoma & 4 & 4 & \\
\hline Lung & Undifferentiated & 7 & 2 & $\because$ \\
\hline $\begin{array}{l}\text { Prostate with } \\
\text { lung metastases }\end{array}$ & Adenocarcinoma & 1 & 0 & 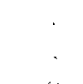 \\
\hline Hypernephroma & Adenocarcinoma & 4 & 0 & \\
\hline $\begin{array}{l}\text { Bladder with } \\
\text { lung metastases }\end{array}$ & Transitional cell & 1 & 0 & $\cdot$ \\
\hline $\begin{array}{l}\text { Gallbladder with } \\
\text { liver metastases }\end{array}$ & Adenocarcinoma & 1 & 0 & \\
\hline $\begin{array}{l}\text { Pancreas with } \\
\text { liver metastases }\end{array}$ & $\begin{array}{l}\text { Adenocarcinoma } \\
\text { (not islet cell) }\end{array}$ & 7 & 3 & \\
\hline Esophagus & Squamous cell & 3 & 1 & \\
\hline Skin & Mycosis fungoides & 2 & 2 & \\
\hline Skin & Squamous cell & 1 & 1 & \\
\hline Skin & Melanoma & 2 & 2 & \\
\hline $\begin{array}{l}\text { Thy roid with } \\
\text { neck metastases }\end{array}$ & Adenocarcinoma & 1 & 0 & \\
\hline Brachial plexus & Neurosarcoma & 1 & 1 necrosis & \\
\hline $\begin{array}{l}\text { Gartner's duct } \\
\text { tumor }\end{array}$ & Adenocarcinoma & 1 & 1 necrosis & \\
\hline $\begin{array}{l}\text { Tongue with } \\
\text { node metastases }\end{array}$ & Squamous cell & 1 & 1 & \\
\hline
\end{tabular}

\section{LITERATURE CITED}

1. Griem, M. L., F. D. Malkinson, and P. H. Morse. Radiology, 77:486, 1961.

2. Malkinson, F. D., M. L. Griem, and P. H. Morse. J. Invest. Dermatol., 37:337, 1961.

3. Walaszek, E. J., J. J. Kocsis, G. V. LeRoy, and E. M. Geiling. Arch. internat. pharmacodyn., $125: 371,1960$. 


\title{
A NEW SIMPLIFIED METHOD FOR PERFUSING DOG SKIN ${ }^{*}$.
}

By

\author{
K. Adachi ${ }^{\dagger}$ and D. C. Chow
}

Perfusion of isolated surviving internal organs has been a widely used method in the study of intermediary metabolism in the last 60 years. The technique implies removal of the organ and perfusion via its main artery using either the animal's own blood or physiological salt solutions. Test substances can be introduced into such a system with the fluid entering the organ, and subsequently samples of the out-flowing venous perfusate or of the organ tissue itself can be analyzed to obtain information about the fate of the substances introduced. The advent of radioactive isotopes has greatly enhanced the value of this technique in the study of organ-specific metabolic processes. Although it is a disadvantage of this method that the organ studied has been removed from its normal environment, particularly from hormonal and central nervous influences, it has yielded highly important results concerning the cellular metabolism of various organs.

Until the late 1930 's the technique was considered inapplicable to the skin because no major artery was known to supply major areas of the skin. However, in 1938 Malmejac and Desanti ${ }^{1}$ discovered that the skin on the medial aspect of the thigh of the dog is supplied by a fairly strong saphenous artery, the few muscular branches of which can be easily tied off. These authors also found that the skin here is easily detachable from the underlying fascia. Baisset et al. ${ }^{2}$ performed a few experiments perfusing this particular area and studying the fate of glucose.

Subsequently, Feldberg and Paton ${ }^{3}$ applied the method to a study of the release of histamine from the skin in the cat, using an incomplete excision and leaving the saphenous nerve intact.

In 1953, Kjaersgaard ${ }^{4}$ gave a detailed description of the technique which with certain modification was used also by Bell et al. ${ }^{5}$ Halprin and Chow ${ }^{6}$ using this model studied in detail synthetic processes in the skin after introducing $C^{14}$-labeled acetate into the perfusion fluid. Wheatley et al. ${ }^{7}$ studied formation of branched chain fatty acids by the skin from the branched chain amino acids valine and isoleucine. Ainsworth ${ }^{8}$ perfused rabbit skin in a similar fashion in his study of percutaneous absorption. Adachi ${ }^{9}$ used this method for studies on cutaneous glycogen metabolism.

Kjaersgaard and subsequent authors have isolated the skin to be perfused and placed it in an appropriate perfusion box with controlled temperature and humidity. Because of the particu-. lar anatomical situation, it appeared to be possible to "perfuse" the medial aspect of the thigh in the dog without complete removal of the skin flap, and using the animal's own blood from the femoral artery as the perfusion fluid. Thus an isolated cutaneous circulatory system is created and at the same time hormonal, nervous and other functional effects continue to exert their influence on the "perfused" portion of the skin. Such a method obviously more closely resembles

\footnotetext{
*This report is taken from a paper appearing in J. Investigative Dermatology, 39:299, 1962.

$\dagger$ Present address: Department of Biochemistry, Yokohama University School of Medicine, Urafune-cho, Minami-ku, Yokohama, Japan.
} 
the condition in vivo than the completely isolated skin model.

This new modification of the perfusion technique is described in the present paper.

\section{EXPERIMENTAL}

A. General preparation. The dogs used for the experiments weigh between 40 and $60 \mathrm{lbs}$. Nembutal is given intravenously, the dosage being approximately $60 \mathrm{mg} / 5 \mathrm{lbs}$. Heparin (1000 units) is given with the Nembutal to prevent coagulation. The dog is fixed on the operating table in a supine position, and the hair is removed from the medial aspect of the thigh either by shaving with a razor blade or by clipping with an electric hair clipper.

B. Dissection of the saphenous artery and vein. The first incision is made on the posterior aspect of the thigh from approximately $5 \mathrm{~cm}$ above the popliteal fossa to $2 \mathrm{~cm}$ below it. Bleeding from the incised skin is controlled either by ligature or by electrocoagulation. The skin is detached from the subcutaneous tissue with a gentle pull towards the knee. On the lower surface of the flap one can easily see the saphenous artery, vein, and nerve, as well as the cutaneous and muscular brinches of the vessels running parallel to each other. The vessels are carefully dissected and the saphenous artery and vein are ligated $1 \mathrm{~cm}$ distally from the origins of the main cutaneous branches. The two easily visible muscular branches are also ligated.

C. Exposure of femoral artery and vein. The femoral artery can be located through the skin in the inguinal region by its strong pulsation. A $5 \mathrm{~cm}$ long incision is made through the skin parallel to the Poupart ligament. The femoral artery and vein are dissected with caution and without injuring the femoral nerve.

D. Preparation of shunts from the femoral artery and vein to the main cutaneous branches of the saphenous artery and vein. For preparing the shunts the following materials are used: 1) large polyethylene tubings with an inner diameter of 0.115 inches and approximately 5 inches in length (PE 330, Clay-Adams Co., New York) with tubing adapter to male luer-lock (Plastic tubing adapter, size "D," Clay-Adams Co.) at one end; 2) small polyethylene tubings, 0.030 inches in inner diameter and approximately 4 inches in length (PE 60, Clay-Adams Co.) with a tubing adapter to female luer-lock (size "B," Clay-Adams Co.) at one end; and 3) three-way stopcocks (Becton, Dekinson and Co., New Jersey) to which the male and female tubing adapters can be connected.

After exposure of the femoral artery its distal portion is ligated and the proximal portion is compressed. An incision is made in the dissected artery. The large tubing with its adapter and with attached stopcock in closed position is inserted through the incision into the artery, pushed upward into the abdominal aorta and secured. Subsequently, the proximal portion of the saphenous artery is ligated and the smaller tubing is inserted and tied near the origin of the cutaneous branch. The attached adapter of the small tubing is connected to the stopcock. By this procedure blood from the abdominal aorta can be shunted to the main cutaneous branch of the saphenous artery after opening of the stopcock. Circulation to other parts of the limb is eliminated.

A by-pass from the vein to the saphenous vein is established in a similar manner.

E. Testing the extent of the perfused area. One-tenth per cent methylene blue aqueous solution is injected dropwise from the free end of the stopcock into the arterial system, so slowly that the injection of $20 \mathrm{ml}$ fluid requires 5 minutes. The skin from the medial and anterior aspects of thigh and leg are removed and frozen at $0^{\circ} \mathrm{C}$. The frozen piece is cut into 12 smaller 


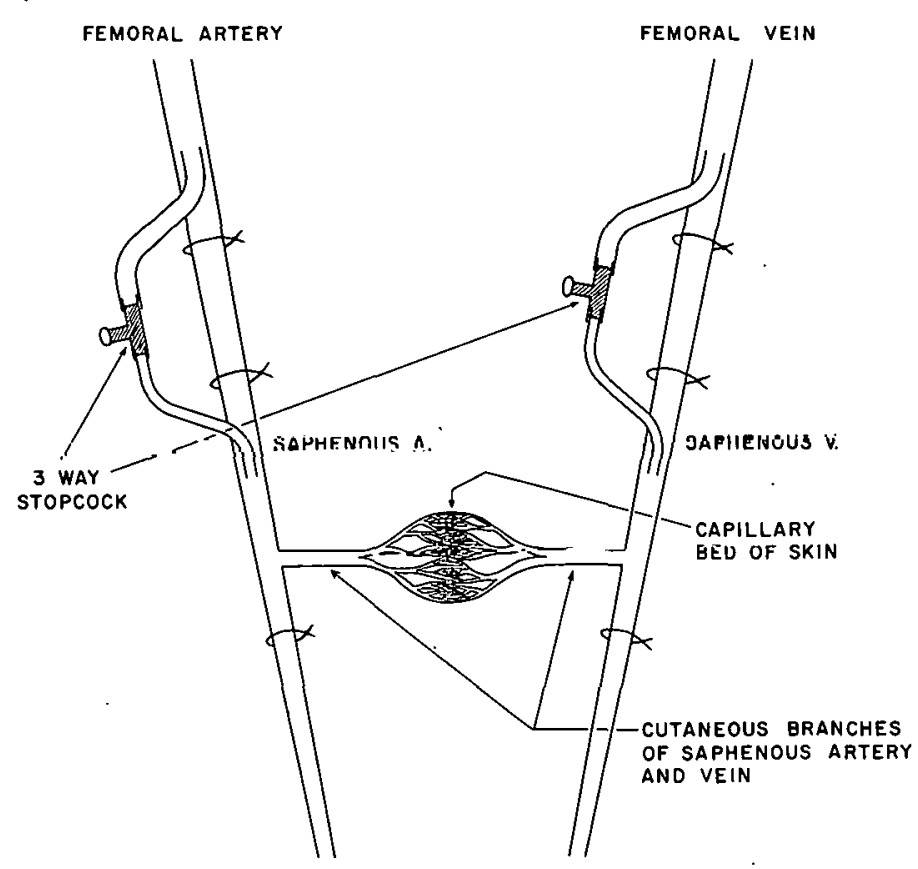

Figure 1. Scheme of operation restricting blood supply to the skin of the inner aspect of the thigh (see text).

sections which are marked according to their anatomical positions. Frozen sections are prepared from each sample and examined microscopically. The samples are also inspected grossly for the presence of dye in the cutaneous and subcutaneous vascular system.

This examination shows that subcutaneous tissue and musculature are not stained and that the perfused skin area extends over the antero-medial aspect of the whole thigh.

\section{DISCUSSION}

Recently Goodman et al. ${ }^{10}$ have established a shunt preparation in which the blood was shunted from the femoral artery directly into the femoral vein in the dog. The dogs survived this operation for more than 3 weeks without gross necrosis of the limb and without other complications, and could be employed in long-term experiments when using heparin and sedatives.

This method has been applied to the specific purpose of skin perfusion primarily in order to make long-term perfusion studies, such as the mechanism of hair production, feasible.

The new method also has certain advantages for short-term experiments:

(1) perfusion is donc under more normal physiological conditions than when the skin is excised.

(2) the operation procedure is considerably simpler and faster than the Kjaersgaard methods taking 10 minutes instead of 30 to 40 minutes.

(3) no supplementary apparatus is required to regulate temperature, humidity and pressure.

Should a control experiment be carefully designed, the modified procedure can be used for all purposes for which the original model was designed. These include:

(1) study of the fate of substances introduced at the arterial end by analyzing skin tissue and/or outflowing venous fluid after perfusion. 
(2) study of excretory functions by introducing materials into the artery and analyzing surface wipings of the skin.

(3) Study of percutaneous absorption by applying materials to the skin surface and analyzing the outflowing perfusion fluid.

It is obvious that the shunting of blood in the described manner will change the dynamics of blood flow, but it seems that for the purpose of metabolic experiments, particularly with iso $\frac{1}{5}$ topes, the change in hemodynamics is not a disturbing factor. In preliminary experiments, 20 microcuries of $\mathrm{C}^{14}$-glucose was perfused with this method for 20 minutes and subsequently polysaccharides, mainly glycogen, were subjected to isolation from the perfused skin, from the underlying muscle, and from the skin sample obtained from the symmetrical region of the other thigh.. Considerable radioactivity was found in the polysaccharide fractions of the perfused skin, while no radioactivity was detected in the samples from muscle and from the skin of the opposite side.

\section{ACKNOWLEDGMENTS}

The authors are grateful to Dr. Richard Goodman for his suggestion in preparing the femoral-saphenous shunt, and to Dr. Stephen Rothman for suggestions and for help in preparing this manuscript.

\section{LITERATURE CITED}

1. Malméjac, J., and E. Desanti. Comptes rendus Soc. Biol., 127:542, 1938.

2. Baisset, E., L. Buguard, J. J. Rouzard, and L. C. Loula. J. physiol. et path. gen., 37:1583, $1939 / 1940$.

3. Feldberg, W., and W. D. M. Paton. J. Physiol., 114:490, 1951.

4. Kjaersgaard, A. R. J. Invest. Derm.; 22:135, 1954.

5. Bell, R. L., R. Lundquist, and K. M. Halprin. J. Invest. Derm., 31:13, 1958.

6. Halprin, K. M., and D. C. Chow. J. Invest. Derm., 36:431, 1961.

7. Wheatley, V. R., D. C. Chow, and F. D. Kennan. J. Invest. Derm., 36:237; 1961.

8. Ainsworth, M. J. Soc. Cos. Chem., 11:69, 1960.

9. Adachi, K. J. Invest. Derm., 37:381, 1961.

10. Goodman, R. S., D. E. Temple, and A. L. Lorincz. J. Invest. Derm., 37:535, 1961. 


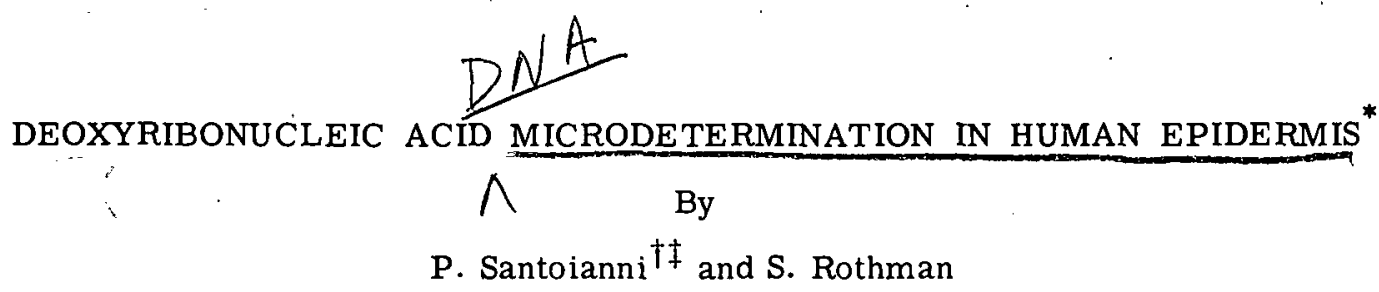

There are some data indicating that $\mathrm{DNA}^{* *}$ is the least variable of all cell constituents 1 and it has been suggested ${ }^{2-6}$ that it may be useful as a reference substance for expression nf the chemioal compositiun of a tissue. We have therefore sought a simple reliable method for estimation of DNA in minute amounts of epidermis.

Chemical methods for the estimation of DNA are based on determination of a) phosphorus, b) purine and pyrimidine constituents, and c) deoxypentose.

Since phosphorus and purine and pyrimidine bases are common to both RNA and DNA, the first two methods involve the quantitative separation of DNA from RNA. These methods are unfortunately time-consuming and require delicate execution. In addition, they do not always accomplish a complete separation of the tissue DNA, since part of it may be extracted together with the RNA, ${ }^{7}$ or because tissue amino acids may interfere with the DNA determination. ${ }^{8}$ These elaborate fractionation procedures can be omitted when the estimation of DNA is based on the determination of deoxypentose.

The principle of simultaneous acid-solubilization of both types of nucleic acids has been applied to DNA determination on small amounts of tissue, ${ }^{9,10}$ but it seemed to us that it might be possible to further simplify the process as applied to the epidermis.

This was made possible by the use of the indole reaction ${ }^{11}$ for DNA determination as modified by Keck, ${ }^{12}$ which is more sensitive and specific than the diphenilamine reaction used in the aforementioned methods, ${ }^{9,10}$ and enables us to work with exceptionally small amounts of material. The microtechnique is based essentially on the nucleic acid extraction procedure described by Ceriotti. ${ }^{13}$

\section{EXPERIMENT'AL}

Apparatus. The epidermis was ground in a homogenizer devised and constructed by the Physics Glass Shop of the University of Chicago (Figurel 1). This consists of a conical tip homogenizer, with a conical plunger which is rotated by chucking the handle to a slow speed rotating motor with rubber tube connection. This type of homogenizer allows grinding smaller amounts of epidermis, lowers the loss of homogenate during transfer, and appears to be better suited for a tough tissue like the epidermis.

Lang-Levy constriction pipettes were used (Microchemical Specialties Co., Berkeley, California) throughout the procedure.

\footnotetext{
* This report is taken from a paper which will appear in J. Investigative Dermatology.

${ }^{\dagger}$ Present address: Clinica Dermatologica Policlinico, Napoli, Italy.

${ }^{\ddagger}$ Aided in part by a grant from the American Cancer Society, Illinois Division.

** The following abbreviations are used in this paper: DNA = deoxyribonucleic acid; $\mathrm{RNA}=$ ribonucleic acid.
} 

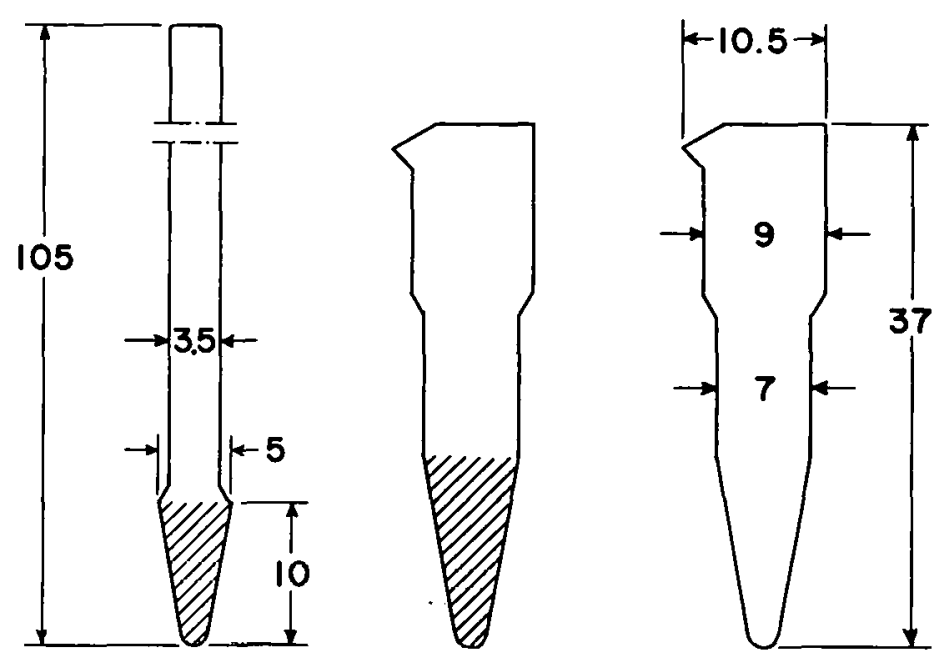

Figure 1. Microhomogenizer made from a Pyrex glass tubing. Dimensions in millimeters.

For DNA extraction, test tubes $26 \times 6 \mathrm{~mm}$ o.d. (Arthur H. Thomas Co., \#2563 M) were used. They were provided with stoppers consisting of a short piece of glass rod, $6 \mathrm{~mm}$ diameter, and having a rubber connecting sleeve (Arthur H. Thumas Co., \#2463 Q).

During the heating period the tubes were placed in stainless steel racks approximately $12 \mathrm{x}$ $6 \times 4 \mathrm{~cm}$ which accommodated 25-30 tubes in $0.7 \mathrm{~cm}$ holes.

Mixing was effected by resting tips of hand-held microtubes against a rotating rubber head mounted on a small electric motor, the speed of which could be regulated by a rheostat. This technique was a modification of the original mixing technique by "buzzing" described by Lowry et al. 14

Centrifugation was carried out in a microcentrifuge (Microchemical Specialties Co., Berkeley, California) or in a centrifuge equipped with a horizontal head carrying metal shields accommodating tube size $50 \mathrm{ml}$. The shields were fitted with cork adapters each provided with 4 holes of about $6 \mathrm{~mm}$ diameter. ${ }^{9}$

DNA determination with indole reagent was performed in $1-\mathrm{ml}$ centrifuge tubes having conical tips and provided with glass stoppers (Microchemical Specialties Co., Berkeley, California).

The colorimetric readings were made with a Beckman D.U. spectrophotometer, equipped with the microcuvettes (Pyrocell, $1.5 \times 10 \times 25 \mathrm{~mm}$ ) and adapter described by Lowry and Bessey. ${ }^{15}$

\section{$\underline{\text { Reagents }}$}

1 - DNA (high polymerized calf thymus DNA from Worthington Biochemicals Corporation, Freehold, New Jersey). The phosphorus content of this preparation was measured by the Fiske and Subbarow procedure, ${ }^{16}$ by which DNA was hydrolyzed and the organic matter destroyed before the colorimetric estimation of total phosphorus. The amount of phosphorus found was 6.8 per cent.

2 - DNA Stock Solution, $2.25 \mathrm{mg} / \mathrm{ml}$. $22.5 \mathrm{mg}$ of DNA was dissolved in $10 \mathrm{ml}$ of distilled water in a small Erlenmeyer flask by agitating the mixture continuously with a magnetic stirrer for 12 hours or more, at $4^{\circ} \mathrm{C}$. The solution was stored frozen. 
3 - DNA Standard Solution, $75 \mu \mathrm{g} / \mathrm{ml}$. One $\mathrm{ml}$ of stock solution was diluted to $30 \mathrm{ml}$ with 10 per cent perchloric acid. This solution was prepared freshly each time. For the standard curve it was further diluted $2,4,8$, and 16 times.

4 - Ethanol-Ethyl Ether Mixture. Three volumes 95 per cent ethanol with 1 volume ethyl ether.

5 - 2 per cent Perchloric Acid.

6 - 10 per cent Perchloric Acid.

7 - 0.06 per cent Indole. Sixty milligrams of indole was dissolved in $100 \mathrm{ml}$ warm distilled water. The solution is stable for several weeks if kept in a Pyrex bottle and refrigerated.

8 - $\underline{\mathrm{N} \mathrm{H} \mathrm{HCl}}$. HCl, sp. gr. 1.19 (Fisher Reagent, A.C.S.).

9 - Indole - HCl Reagent. Twu $\mathrm{ml}$ of solution 7 and $2 \mathrm{ml}$ of solution 8 were mixed and the combined $\mathrm{HCl}$ - Indole reagent, kept in a stoppered flask, was used within a few hours.

10 - Amyl Acetate. (Fisher, purified solvent.)

Procedure

Sample preparation. - Normal human skin was obtained from the legs of fresh surgical specimens. The epidermis was separated from the dermis by the stretch method. ${ }^{17}$

Specimens of about $1 \mathrm{mg}$ (wet weight) of epidermis were accurately weighed by a microbalance. Fifty microliters of ethanol-ether mixture ${ }^{*}$ was added to the tissue in the microhomogenizer, and the whole ground for about 30 seconds, the stem of the pestle being connected by a rubber tube to a motor running at about 500-1000 rpm.

Efficient mechanical breakage of the epidermal tissue is important for the efficiency of the DNA hydrolysis procedure which follows, and for obtaining a complete and uniform extraction from materials of different compactness.

The "homogenate" was transferred to a microtube. Another $50 \mu \mathrm{l}$ aliquot of ethanol-ether mixture was used for washing the pestle and the homogenizer. The washing was added to the microtube, and the whole suspension centrifuged at 3000-4000 rpm for 5 minutes at room temperature. The ethanol-ether mixture was pipetted off by a constriction pipette.

The lipid-free, ground tissue was then extracted by adding $100 \mu \mathrm{l}$ of 2 per cent perchloric acid and mixing. The tube was kept at $0^{\circ} \mathrm{C}$ for 10 minutes, centrifuged at 5000-6000 rpm in the refrigerated centrifuge, and the perchloric acid pipetted off. This removes most acid-soluble compounds (inorganic phosphates, low molecular weight organic phosphorus compounds, sugars and co-enzymes containing purine or pyrimidine bases), while nucleic acids are precipitated together with proteins. Higher concentrations of acid and higher temperatures may cause loss of DNA by partial hydrolysis to acid-soluble compounds.

Release of the nucleic acids was accomplished by acid hydrolysis of the nucleic acids to soluble components. The residue from the previous step was suspended in $50 \mu 1$ of 10 per cent perchloric acid, and the stoppered tube was placed in the microtube rack immersed in a water bath at $80^{\circ} \mathrm{C}$ for 10 minutes.

After centrifugation at 5000-6000 rpm for 5 minutes, the supernatant was carefully withdrawn by a constriction pipette and transferred to a storage tube.

A second $50 \mu \mathrm{l}$ aliquot of 10 per cent perchloric acid was added to the residue and the heating at $80^{\circ} \mathrm{C}$ for 15 minutes was repeated.

\footnotetext{
* The homogenization in ethanol-ether mixture defats the tissue and also prevents a possible loss of DNA due to enzyme action.
} 
After centrifugation, the supernatant was pipetted and added to the first hot perchloric acid extract. A $25 \mu \mathrm{l}$ aliquot of 10 per cent perchloric acid was used to wash the residue, and after centrifugation the third supernatant was added to the first and second.

The combined extracts (total volume about $125 \mu \mathrm{l}$ ) were used for the following colorimetric determinations.

DNA determination. - This test depends on the formation of a yellow color when DNA is heated with indole in $\mathrm{HCl}$ solution.

A $100 \mu \mathrm{l}$ aliquot of the tissue extract was pipetted into a centrifuge microtube. A "blank" containing 10 per cent perchloric acid instead of the tissue extract was prepared.

One hundred microliters of indole-hydrochloric acid reagent ${ }^{*}$ was added, and the tubes were closed with aluminum foil caps and kept in a boiling water bath for 10 minutes.

After cooling a few minutes in an ice-bath, $0.4 \mathrm{ml}$ of cold amyl acetate was added to each tube. The tubes were stoppered, mixed for 15 seconds, then centrifuged at low speed for about 1. minute to separate the layers.

Most of the water layer was transferred to a micrucuvette and the absorbancy read at 490 $\mathrm{m} \mu$. Since lower values of absorbancy were observed if the water phase was left in curtact with the amyl acetate for a longer period, the readings were taken within 10-20 minutes.

The amount of DNA was expressed as DNA-P.

Accuracy of the method. -A standard curve for DNA determination with the described method is shown in Figure 2. The average slope of the curve, in three experiments, yielded $0.165 \pm 0.011$ per $1.0 \mu \mathrm{g} / \mathrm{ml}$ DNA-P.

The lowest measurable amount of DNA corresponded to about $0.03 \mu \mathrm{g}$ DNA-P, in $100 \mu \mathrm{l}$ of acid solution.

Repeated extraction of DNA by hot 10 per cent perchloric acid (Figure 3 ) showed that the third extract contained a negligible amount of DNA, and the fourth none.

Recovery experiments. - Two identical aliquots from an epidermis homogenate in ethanolether mixture were treated as above using 2 per cent perchloric acid. To one of the residues after centrifugation, DNA was added as indicated in Table 1. Both residucs were then extracted by heating with 10 per cent perchloric acid, and the DNA determined by the indole reaction. Very good recovery was obtained.

Specificity. - To establish whether one extraction with ethanol-ether mixture and one with 2 per cent perchloric acid were sufficient to eliminate the compounds in the indole reaction which, reacting as DNA, can give erroneously high values of DNA, an experiment was carried out using two extractions with ethanol-ether, and two with 2 per cent perchloric acid. As shown by Table 2, the first ethanol-ether, and 2 per cent perchloric acid extractions removed the interfering material. Any free deoxy ribonucleotides and deoxyribonucleosides present would be taken by the 2 per cent perchloric acid extraction.

To determine whether one extraction with amyl acetate was sufficient for elimination of the pink color ${ }^{12}$ interfering with the yellow color given by deoxypentose, the water phase resulting from the first amyl acetate extraction was subjected to two additional extractions with an equal

More color is developed than when the indole solution and $\mathrm{HCl}$ are added separately. 12,21
Since we found that the $2.5 \mathrm{~N} \mathrm{HCl}$ used by Keck 12 developed too faint a. color, $6 \mathrm{~N} \mathrm{HCl}$ was used. 


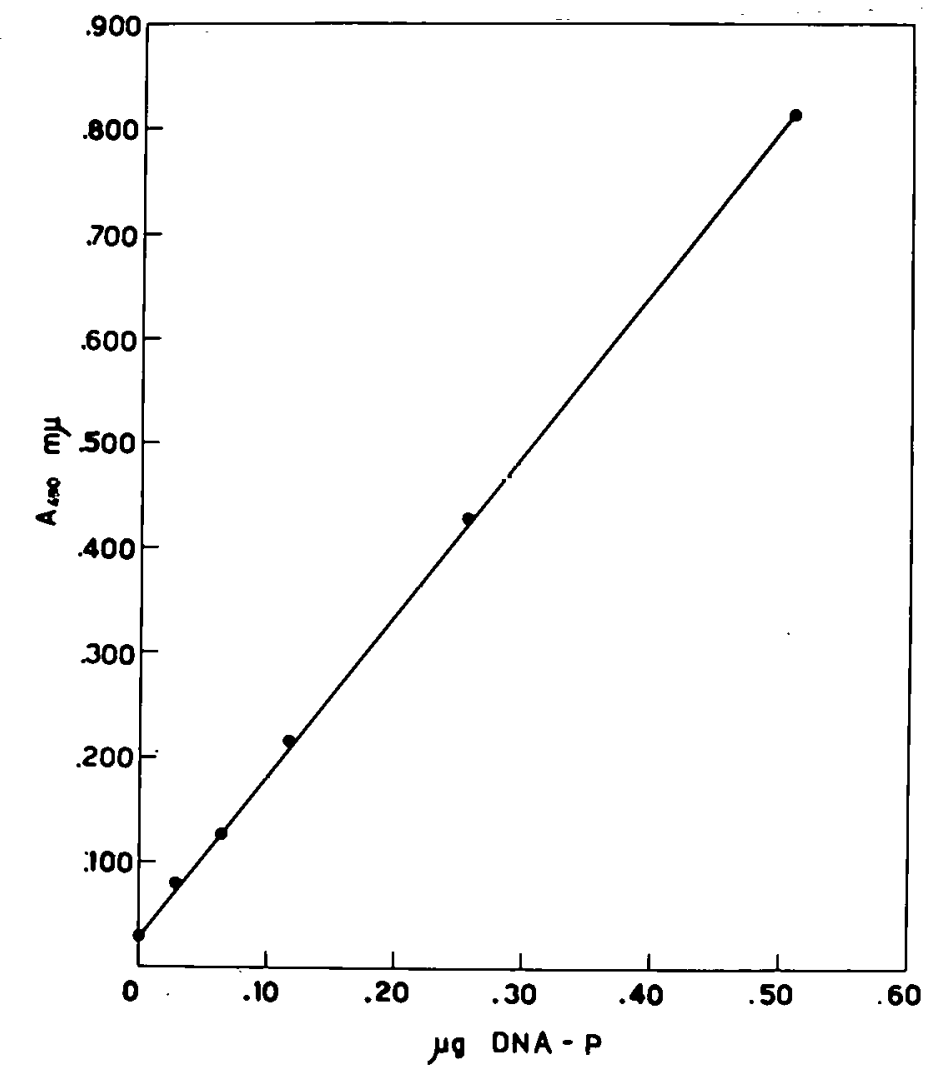

Figure 2. Standard curve for DNA determination. The reaction tubes contained $100 \mu \mathrm{l}$ DNA solution in 10 per cent perchloric acid; $50 \mu \mathrm{l}$ $6 \mathrm{~N} \mathrm{HCl} ; 50 \mu \mathrm{l} 0.6$ per cent indole.

Table 1

RECOVERY OF ADDED DNA

\begin{tabular}{c|c|c|c}
\hline $\begin{array}{c}\text { DNA content } \\
\text { of the sample } \\
\mu \mathrm{g} \text { DNA-P }\end{array}$ & $\begin{array}{c}\text { DNA added } \\
\mu \mathrm{g} \text { DNA-P. }\end{array}$ & $\begin{array}{c}\text { DNA recovered } \\
\mu \mathrm{g} \mathrm{DNA-P}\end{array}$ & $\begin{array}{c}\text { Recovery } \\
\%\end{array}$ \\
\hline 6.25 & 6.80 & 6.54 & 96 \\
$6.25^{\circ}$ & 3.40 & 3.22 & 95 \\
\hline
\end{tabular}

amount $(0.4 \mathrm{ml})$ of amyl acetate. As Table 3 shows, one extraction with amyl acetate was sufficient to eliminate most of the interfering color.

The validity of the method for epidermis homogenates was also tested. To $10-20 \mu \mathrm{l}$ of a 10 per cent homogenate in water was added $200 \mu \mathrm{l}$ of ethanol-ether mixture and the tube was kept in a water bath at $70^{\circ} \mathrm{C}$ for 3 minutes. After centrifugation and pipetting off the ethanol-ether mixture, the determination was carried out as above. The results showed that the method is applicable to routine determinations on epidermis homogenates after they have been used for other determinations. 


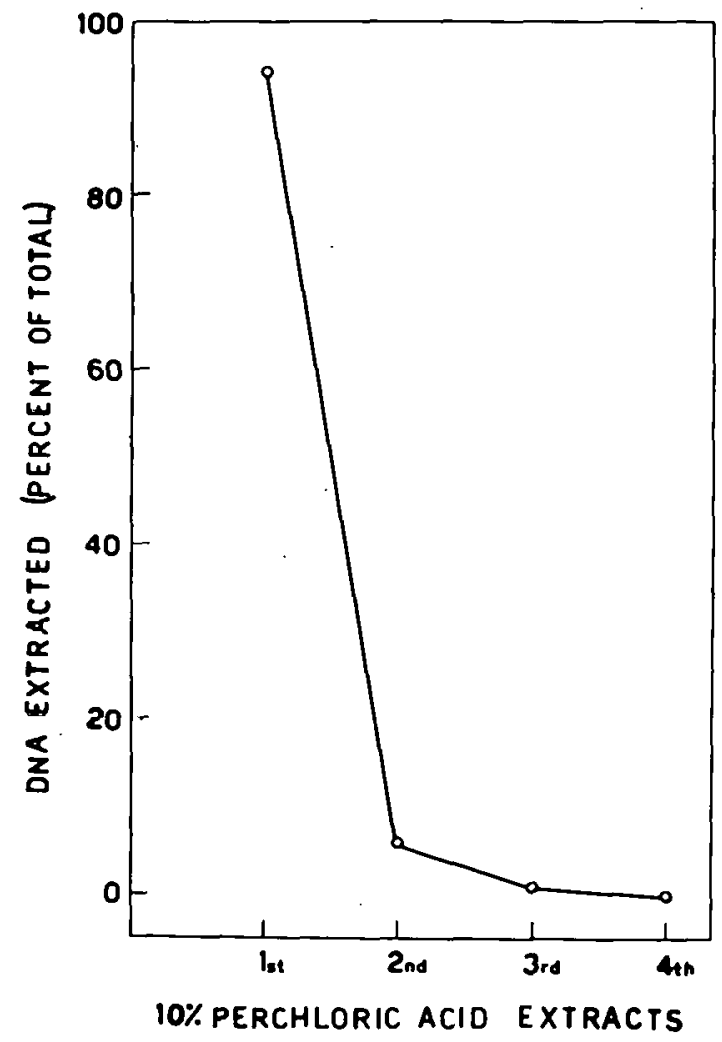

Figure 3. Repeated extractions by 10 per cent perchloric acid of the tissue residue after ethanol-ether and 2 per cent perchloric acid treatment. Fifty microliters of 10 per cent perchloric acid were used each time to extract DNA, heating for 15 minutes at $80^{\circ} \mathrm{C}$.

Table 2

DETERMINATION OF DNA (OR INTERFERING SUBSTANCES) ON A SERIES OF EXTRACTS

\begin{tabular}{l|c}
\hline Extract & $\begin{array}{c}\text { DNA or interfering } \\
\text { substances content } \\
\% \text { of total }\end{array}$ \\
\hline 1st Ethanol-Ether & 2 \\
2nd Ethanol-Ether* & 0 \\
1st 2\% Perchloric Acid & 8 \\
2nd 2\% Perchloric Acid & 1 \\
1st 10\% Perchloric Acid & 85 \\
2nd 10\% Perchloric Acid & 4 \\
\hline
\end{tabular}

* The extracts were evaporated to dryness and the residue taken up in 10 per cent perchloric acid. 
Table 3

ELIMINATION BY AMYL ACETATE OF

THE INTERFERING COLOR IN THE

DEOXYPENTOSE REACTION

\begin{tabular}{c|c}
\hline $\begin{array}{c}\text { Extractions } \\
\text { with Amyl acetate } \\
\text { No }\end{array}$ & $\begin{array}{c}\text { Absorbancy at } 490 \mathrm{~m} \mu \\
\text { of the water phase } \\
\text { after extraction }\end{array}$ \\
\hline 0 & 0.390 \\
1 & 0.285 \\
2 & 0.275 \\
3 & 0.275 \\
\hline
\end{tabular}

Results of DNA determination. Experiments were carried out to compare our results with the data reported for tissues other than epidermis obtained by macromethods.

Soon after death by decapitation, specimens of tissue weighing 1 to $2 \mathrm{mg}$ were taken from various organs of male albino rats, weighing 70-90 g. The results of DNA determination are shown in Table 4 , in comparison with data from the literature. ${ }^{18}$ Good agreement was found with data obtained with macromethods for organs other than skin.

Table 4

DNA CONCENTRATION IN RAT TISSUES

\begin{tabular}{l|c|c}
\hline \multirow{2}{*}{} & \multicolumn{2}{|c}{$\mu \mathrm{g}$ DNA-P/mg of fresh tissue } \\
\cline { 2 - 3 } & Present method & Other method \\
\hline Thymus & 2.55 & $2.40-3.09$ \\
Spleen & 1.40 & $1.15-1.35$ \\
Liver & 0.30 & $0.21-0.31$ \\
\hline
\end{tabular}

Mean value of three determinations on tissue from the same animal.

${ }^{\dagger}$ Method of Schneider and Klug. Data reported by Davidson (18).

DNA content of human epidermis and of scales. -The DNA content of five specimens of epidermis from normal human skin separated from the dermis by the stretch method was estimated by the described method. The results of duplicate determinations for each specimen are shown in Tablc 5.

DNA determinations carried out on scales from patients affected by psoriasis, and on scales from subjects not presenting any skin disease showed that the average content of DNA in three specimens of psoriatic scales was $0.20 \mu \mathrm{g}$ of $\mathrm{DNA}-\mathrm{P} / \mathrm{mg}$ scales, while no DNA was found in the scales from normal skin.

The values for DNA content of normal human epidermis fall in the same range as those for guinea pig epidermis as reported by Tabachnick. ${ }^{19}$ 
Table 5

DNA CONTENT OF HUMAN EPIDERMIS

\begin{tabular}{c}
\hline$\mu \mathrm{g}$ DNA-P/mg tissue \\
\hline $0.29 \pm 0.01^{*}$ \\
$0.31 \pm 0.01^{*}$ \\
$0.26 \pm 0.01^{*}$ \\
$0.30 \pm 0.02^{*}$ \\
$0.36 \pm 0.02^{*}$ \\
Average $0.30 \pm 0.06^{\dagger}$ \\
\hline Standard deviation of duplicate measure- \\
ments. \\
†' \\
Standard deviation of the mean.
\end{tabular}

\section{DISCUSSION}

The described method is simple, fast enough for routine determinations, and accurate. It can be applied to homogenates after they have been used for other determinations or to freezing microtome sections. Where necessary, the tissue can be left a few hours in absolute ethanol, then stored in ethanol-ether mixture before determinations are carried out. ${ }^{13}$

The choice of a reference substance for the expression of experimental data on chemical composition of a tissue is especially difficult in heterogeneous tissues such as the epidermis. Dry or wet weights are most commonly used but these may give misleading interpretations of the variations occurring in the tissue ${ }^{2,3}$ because of the variable amounts of inert keratin and of other constituents which may affect the number of living cells per unit weight. Essentially the same difficulty is encountered when protein $\mathrm{N}$ or total $\mathrm{N}$ are used as references for expressing the chemical composition of epidermis.

A good approach to the resolution of the problem is reached using the nucleic acid content of the tissue as reference basis, but the concentration of ribonucleic acid in the cells varies in some physiological and pathological states. ${ }^{18}$ On the other hand, the deoxyribonucleic acid content of the cell nucleus is constant for the different somatic tissues of the same individual and for different individuals of the same species. ${ }^{1}$ The DNA content per nucleus is constant as long as no changes in chromosome number occur. ${ }^{20}$ It has further been demonstrated ${ }^{3}$ that in the liver the DNA content per cell does not vary with sex, protein or vitamin-deficient diets, and induced carbohydrate or fat metabolic alterations.

The stability of the content of DNA in the cell suggests that DNA determinations may prove useful as reference values for analytical work on the epidermis, ${ }^{6}$ and will be a better indication of enzyme changes in physiological and pathological states. DNA determination has been found ${ }^{21}$ useful for determination of growth in tissue cultures.

If the enzymatic activity is expressed per units of DNA, and if the unit of DNA chosen is the amount per nucleus, the enzyme concentration may be approximately estimated on a cellular basis. 18

In the epidermis, the reference of the chemical composition of the tissue to DNA takes into account only the nucleated cells, which are the site of the most significant biological activities. 
Furthermore, the relation of the chemical composition of epidermis to DNA content, renders possible better comparison with the values of biochemical activity of other tissues.

As a reference basis for epidermis, DNA is of value only, of course, when it is possible to assume that the chemical constituent or the enzymatic activity to be related to the DNA content of the tissue is present only in normally nucleated cells. Conditions such as parakeratosis and poliploidy will make the interpretation of DNA as a reference value rather difficult.

\section{LITERATURE CITED}

1. Vendrely, R. In E. Chargaff and J. N. Davidson, The Nucleic Acids, Vol. 2, New York: Academic Press, Inc., 1955.

2. Davidson, J. N., and I. Leslie. Nature, 165:49, 1950.

3. Thcmson, R. Y., F. C. Heagy, W. C. Hutchison, and J. N. Davidson. Biochem. J., 53:460, 1953.

4. Mandel, P. Exposés annuals de biochimie médicale, 13 ème Serie, Paris: Masson et Cie, 1951 , p. 255.

5. Kosterlitz, H. W. Symposium on liver function. American Institute of Biological Sciences Publication, No. 4, 1958.

6. Griesemer, R. D. J. Biophys. Biochem. Cytol., 2:523, 1956.

7. Drasher, M. L. Science, 118:181, 1953.

8. Scott, J. F., A. P. Fraccastoro, and E. B. Taft. J. Histochem. Cytochem., 4:1, 1956.

9. Steele, R., T. Sportunato, and L. Ottolenghi. J. Biol. Chem., 177:231, 1949.

10. Patterson, E. K., and M. E. Dakerman. Arch. Biochem. Biophys., 36:97, 1952.

11. Ceriotti, G. J. Biol. Chem., 198:297, 1952.

12. Keck, K. Arch. Biochem. Biophys., 63:446, 1956.

13. Ceriotti, G. J. Biol. Chem., 214:59, 1955.

14. Bessey, O. A., O. H. Lowry, M. J. Brock, and J. A. Lopez. J. Biol. Chem., 166:177, 1946.

15. Lowry, O. H., and O. A. Bessey. J. Biol. Chem., 163:633, 1946.

16. Leloir, L. F., and C. E. Cardini. . In S. P. Kolowick and N. O. Kaplan, eds., Methods in Enzymology, Vol. 3, New York: Academic Press, Inc., 1957.

17. Van Scott, E. J. J. Invest. Derm., 18:377, 1952.

18. Davidson, J. N. In: The Biochemistry of Nucleic Acids, 4th ed., New York: John Wiley and Sons, Inc., 1960.

19. Tabachnick, J. J. Invest. Derm., 32:563, 1959.

20. Swift, H. Int. Rev. Cytol., 2:1, 1953.

21. Bonting, S. L., and M. Jones. Arch. Biochem. Biophys., 66:340, 1957. 


\title{
THE BIOSYNTHESIS OF RNA: PRIMING BY POLYRIBONUCLEOTIDES ${ }^{*} \dagger$
}

\author{
By \\ T. Nakamoto ${ }^{\ddagger}$ and S. B. Weiss
}

Two distinctly different enzymes are involved in polyribonucleotide formation, polynucleotide phosphorylase ${ }^{1}$ and RNA polymerase. ${ }^{2-6}$ The former enzyme catalyzes the synthesis of $\mathrm{RNA}^{* *}$ in the presence of nucleoside diphosphates but in the absence of any known directing primer. ${ }^{7}$ A similar reaction is catalyzed by RNA polymerase, but requires the presence of all four nucleoside triphosphates as well as a DNA primer which directs the assembly of complementary RNA chains. ${ }^{8,9}$ Reports from a number of laboratories have suggested that a third re action which uses RNA as a primer for the synthesis of RNA, may also be present in living cells. ${ }^{10-14}$

In the course of testing various primers with somewhat crude preparations of RNA polymerase isolated from extracts of Micrococcus lysodeikticus, we observed that these preparations catalyzed the incorporation of labeled ribonucleotides into RNA if either DNA or plant viral RNA was present. Optimum labeling of RNA required the presence of all four triphos phates with either primer. While incorporation in the presence of viral RNA was relatively low (approximately 20 per cent of the incorporation achieved with DNA) this phenomenon was consistently observed. However, as the M. lysodeikticus extracts were purified with respect to the DNA-dependent reaction (over 400 fold), the RNA-dependent incorporation was markedly reduced. This suggested that separate enzymes might be responsible for the priming of polyribonucleotide synthesis by DNA and RNA. Experiments with synthetic polynucleotides of known composition have provided a clear demonstration of the RNA-dependent synthesis of RNA in extracts from $\underline{M}$. lysodeikticus, and are reported in this communication.

\section{METHODS AND MATERIALS}

Ribonucleoside triphosphates labeled with $\mathrm{P}^{32}$ in the ester phosphate only, were prepared as previously described ${ }^{3}$ and in addition by the method of Tener. ${ }^{15}$ Turnip yellow mosaic virus RNA (TYMV) free from protein was supplied by Dr. R. Haselkorn. Calf thymus DNA was purchased from the Sigma Chemical Company, 3500 DeKalb Street, St. Louis 18, Missouri. Polynucleotide phosphorylase, purified from $\underline{M}$. lysodeikticus as described by Steiner and Beers, 16 and poly $\mathrm{A}$, poly $\mathrm{C}$ and poly $\mathrm{U}$ were contributed by Dr. S. Yachnin, to whom we are deeply grate-

\footnotetext{
7 (may

${ }^{*}$ This report is taken from a paper appearing in Proc. Nat. Acad. Sci., 48:880 1962 )

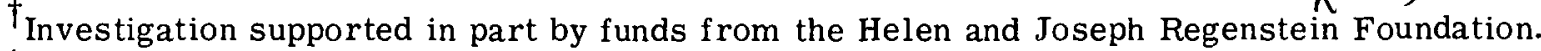

${ }^{\ddagger}$ Department of Biochemistry, University of Chicago. Present Address: The Rockefeller Institute, 66 and York Avenue, New York 21, New York.

** The following abbreviations are used: RNA, ribonucleic acid; DNA, deoxynucleic acid; CTP, ATP, UTP and GTP for the tri- and CDP, ADP, UDP and GDP for the di- and CMP, AMP, UMP and GMP for the monophosphates of cytidine, adenosine, uridine and guanosine; the capital letters C, A, U, G, T and I for the above nucleotides including thymine and inosine or their corresponding residues in polynucleotide chains; Tris, tris (hydroxymethyl) aminomethane and TCA, trichloroacetic acid.
} 
ful. Polyribonucleotides prepared with this enzyme were phenol treated, ${ }^{17}$ precipitated with ethanol, dissolved in $0.05 \mathrm{M} \mathrm{NaCl}-0.005 \mathrm{M}$ sodium citrate, and exhaustively dialyzed first against $0.05 \cdot \mathrm{M} \mathrm{NaCl}$ and then against water. Poly $\mathrm{CA}$ was prepared from a mixture of CDP and ADP in molar ratio $4: 1$, poly CU from a mixture of CDP and UDP in molar ratio of $4: 1$, poly CAU from a mixture of CDP, ADP and UDP in molar ratio of 4:1:1 and poly AU from a mixture of ADP and UDP in a molar ratio of $2: 1$. The base composition of the mixed polyribonucleotides described above was determined by alkaline hydrolysis and paper electrophoresis, ${ }^{18}$ and nearest neighbor studies were performed as previously described. 19

The enzyme was prepared by exposing lysozyme lysates of M. lysodeikticus to sonic oscillation for five minutes, and centrifuging for 90 minutes at $105,000 \mathrm{x}$. The clear supernatant was then treated with protamine sulfate, and the precipitate extracted once with $0.05 \mathrm{M}$ phosphate of $\mathrm{pH} 7.5$, and again with $0.20 \mathrm{M}$ phosphate of the same $\mathrm{pH}$. The second phosphate extract was adsorbed onto calcium phosphate gel and the gel was extracted once with $0.20 \mathrm{M}$ phosphate, $\mathrm{pH}$ 7.5. This preparation had an average protein concentration of 4-5 mg per $\mathrm{ml}$ and a ratio of absorbancy of about 1.55 at 280 to $260 \mathrm{~m} \mu$.

Routine assays for labeled nucleotide incorporation into RNA were performed by adding cold 50 per cent TCA to the reaction vessels after incubation to give a final concentration of 10 per cent. The vessels were iced for 3 minutes, $2 \mathrm{ml}$ of cold per cent TCA was added, mixed and the precipitate collected by filtration through a millipore filter. The precipitate was washed three times with $5 \mathrm{ml}$ portions of cold 5 per cent TCA. The millipore filters were dried in planchets, and the radioactivity of the acid-insoluble residue determined with a windowless gas flow counter.

\section{EXPERIMENTAL}

The enzyme preparation described above, when incubated with all four ribonucleoside triphosphates in the presence of TYMV RNA, catalyzes the incorporation of labeled ribonucleotides into RNA (Table 1). Optimum incorporation requires the addition of a full complement of the triphosphates.

Table 1

THE NUCLEOTIDE REQUIREMENT FOR RNA LABELING WITH TYMV RNA AS PRIMER

\begin{tabular}{c|c|c|c}
\hline $\begin{array}{c}\text { Experiment } \\
\text { number }\end{array}$ & $\begin{array}{c}\text { Labeled } \\
\text { substrate }\end{array}$ & Nucleotides added & $\begin{array}{c}\text { Labeled substrate } \\
\text { incorporated into } \\
\text { RNA, m } \mu \text { moles }\end{array}$ \\
\hline 1 & CTP32 & Completc & 1.48 \\
& & Omit GTP & 0.07 \\
& & Omit UTP & 0.51 \\
& Omit ATP & 0.52 \\
& Omit ATP, UTP, GTP & 0.08 \\
\hline
\end{tabular}

The complete system contained $2 \mu$ moles of $\mathrm{MnCl}_{2}, 30 \mu$ moles of Tris $-\mathrm{PO}_{4}$ buffer $(1: 1)$ of pH $7.5,0.10 \mu$ moles each of ATP, UTP, CTP and GTP, $50 \mu \mathrm{g}$ of TYMV RNA and $0.04 \mathrm{ml}$ of the enzyme preparation containing $6 \mathrm{mg}$ of protein per $\mathrm{ml}$ and $0.10 \mu$ moles of CTP $32\left(1.24 \times 10^{6}\right.$ cpm per $\mu$ mole), was substituted for unlabeled CTP where indicated. The final volume of the system was $0.50 \mathrm{ml}$ and the vessels were incubated for 30 minutes at $30^{\circ}$. 
With TYMV-RNA as primer, omission of any one ribonucleotide resulted in a significant decrease in label incorporation, although the system appeared to be most sensitive to the deletion of GTP (Table 1). This phenomenon was consistently observed with TYMV-RNA as primer but not with DNA. A number of explanations was considered for the apparent "essentiality" of GTP in this system, but none was satisfactory. A series of experiments was then conducted using synthetic polyribonucleotides and the observations made above were confirmed and extended.

When various homopolymers of ribonucleotides were incubated with the microbial preparations, it was found that poly $\mathrm{C}$ caused a rapid and remarkable high incorporation of $\mathrm{P}^{32}$-GMP into the acid-insoluble fraction (Table 2). This incorporation was independent of ATP, UTP and

Table 2

THE PRIMING ACTION OF POLY C FOR GTP ${ }^{32}$ INCORPORATION

\begin{tabular}{c|l|l|l|c}
\hline $\begin{array}{c}\text { Experiment } \\
\text { number }\end{array}$ & $\begin{array}{c}\text { Labeled } \\
\text { substrate }\end{array}$ & Primer & \multicolumn{1}{|c}{ Additions } & $\begin{array}{c}\text { Labeled substrate } \\
\text { incorporated into } \\
\text { RNA, m } \mu \text { moles }\end{array}$ \\
\hline $1^{*}$ & GTP32 & Poly C & None & 37.0 \\
& & & ATP, UTP, CTP & 27.0 \\
$2^{\dagger}$ & GTP32 & Poly C & None (heated enzyme) & 0.2 \\
& & & GDP $(2.0 \mu$ moles $)$ & 13.8 \\
& CTP32 & & None & 15.1 \\
& ATP32 & None & 0.1 \\
& UTP32 & Poly U & None & 0.1 \\
& Poly A & None & 0.2 \\
\hline
\end{tabular}

Each vessel contained $1 \mu$ mole of $\mathrm{MnCl}_{2}, 30 \mu$ moles of Tris: $\mathrm{PO}_{4}$ buffer (1:1) of pH 7.5, $0.20 \mu$ moles of GTP $32\left(1.9 \times 10^{6} \mathrm{cpm}\right.$ per $\mu$ mole $), 10 \mu \mathrm{g}$ of poly C and $0.4 \mathrm{mg}$ of the enzyme preparation. Where indicated, $0.4 \mu$ moles each of unlabeled ATP, UTP and CTP were added and enzyme heated at $100^{\circ}$ for 5 minutes was used as the heated enzyme. The final volume of the system was $0.25 \mathrm{ml}$ and the vessels were incubated for 15 minutes at $37^{\circ}$.

t The reaction mixture and the conditions of incubation were the same as above except that each vessel contained $0.20 \mathrm{mg}$ of enzyme preparation. Where indicated $0.08 \mu$ moles of CTP 32 $\left(1.6 \times 10^{6} \mathrm{cpm}\right.$ per $\mu$ mole), $0.04 \mu$ moles of ATP $32\left(4.0 \times 10^{6} \mathrm{cpm}\right.$ per $\mu$ mole $)$ and $0.10 \mu$ moles of UTP $32\left(4.7 \times 10^{6} \mathrm{cpm}\right.$ per $\mu$ mole) replaced GTP 32 , and $10 \mu \mathrm{g}$ of poly $\mathrm{U}$ or poly A replaced poly C.

CTP, and only $\mathrm{GTP}^{32}$ resulted in label incorporation. This activity could not be attributed to polynucleotide phosphorylase, since the reaction system contained a relatively large concentration of inorganic phosphate which would have inhibited polymerization by this enzyme. Furthermore, the addition of GDP, 8 times in excess of $\mathrm{GTP}^{32}$, resulted in no decrease of label incorporated. The apparent priming by poly $\mathrm{C}$ for poly $\mathrm{G}$ synthesis was quite vigorous. Indeed, net quantities of poly $G$ have been recently prepared. We were therefore surprised to find that neither poly $U$ nor poly A alone could prime the incorporation of $\mathrm{ATP}^{32}$ or $\mathrm{UTP}^{32}$ respectively. This suggested that cytidine residues in RNA primers were important for the polymerization of ribonucleotides by the RNA-dependent enzyme. To test this hypothesis, a number of synthetic polymers containing cytidine and other ribotides were prepared. 
Table 3 shows that a number of cytidine copolymers prime the incorporation of labeled GTP, optimum incorporation being dependent on the presence of a complete complement of the ribonucleoside triphosphates complementary to those bases present in the synthetic copolymers. Similar results were obtained with $\mathrm{UTP}^{32}$ and $\mathrm{ATP}^{32}$. Base analysis of the copolymers revealed that the content of cytidine reflected the high ratio of CDP to ADP and/or UDP used during preparation of the synthetic polyribonucleotides (see Methods). This suggests that large regions of the copolymers consist of poly $\mathrm{C}$ sequences. Thus, the data shown in Table 3 are remarkable in that the omission of one of the complementary ribonucleotides from the reaction mixture for a given copolymer, results in an impressive decrease in label incorporated.

Table 3

THE PRIMING BY POLYNUCLEOTIDES OF LABELED NUCLEOTIDE INCORPORATION

\begin{tabular}{c|c|c|c|c}
\hline $\begin{array}{c}\text { Experiment } \\
\text { number }\end{array}$ & Polynucleotide & $\begin{array}{c}\text { Labeled } \\
\text { substrate }\end{array}$ & Additions & $\begin{array}{c}\text { Labeled nucleotide } \\
\text { incorporated into } \\
\text { RNA, m } \mu \text { moles }\end{array}$ \\
\hline \multirow{2}{*}{1} & Poly C & GTP 32 & None & 26.60 \\
& Poly CA & & UTP & 4.50 \\
& Poly CU & & None & 0.59 \\
& Poly CAU & & ATP & 7.83 \\
& & None & 0.80 \\
& & ATP, UTP & 2.96 \\
& & ATP & 0.47 \\
& & UTP & 0.71 \\
\hline
\end{tabular}

The reaction mixture and conditions of incubation were the same as indicated in Table 2 except that $20 \mu \mathrm{g}$ each of poly $\mathrm{C}$, poly CA, poly CU and poly CAU were used where indicated.

When the RNA's prepared in the presence of the different cytidine containing polymers were isolated and subjected to alkaline hydrolysis and paper electrophoresis, only the $2^{\prime}, 3^{\prime}$-nucleoside monophosphates of the bases complementary to the copolymers employed were labeled. Figure 1 is a composite of various electropherograms of the alkaline digest products of the RNA's prepared with the various polyribonucleotide primers. The results suggest that each synthetic polymer primes the polymerization of a complementary strand of RNA in a fashion similar to the DNA-dependent reactions described previously. ${ }^{9}$ Data consistent with and in support of this idea, were obtained by determining the base composition of the newly formed polyribonucleotides as described by Josse and coworkers. ${ }^{20}$

Tables 4, 5 and 6 present the $\mathrm{P}^{32}$ content in the various $2^{\prime}, 3^{\prime}$-nucleotides isolated after alkaline digestion and electrophoresis of the enzymatically synthesized RNA's. From these data, one may calculate the composition of each polyribonucleotide synthesized, independent of the spectrophotometric analysis used for primer base composition determinations. The total amount of any one nucleotide incorporated as a $5^{\prime}$-nucleotide, must be equal to the total amount of the same nucleotide isolated as the 2',3'-isomer after alkaline digestion. For poly CU, the equation for guanine would be: $(\mathrm{ApG}+\mathrm{GpG})=(\mathrm{GpG}+\mathrm{GpA})$. Substituting the appropriate values given in 


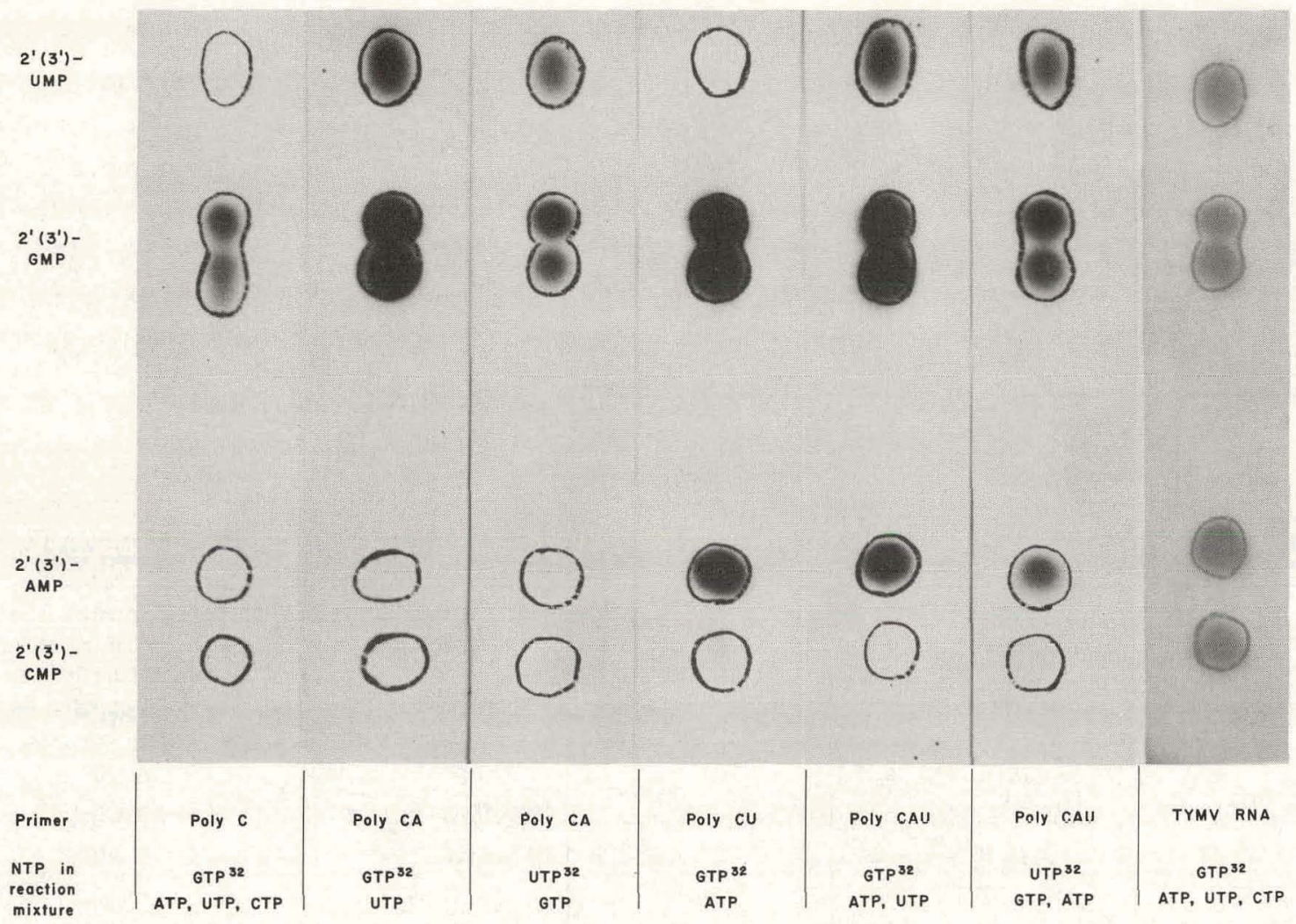

Figure 1. Paper electrophoresis of $\mathrm{P}^{32}$-RNA alkaline digest products prepared enzymatically with different polyribonucleotide primers. The primers, labeled substrates and nucleotides added for each reaction are listed below the individual electropherogram. The encircled areas represent ultraviolet absorbing regions. Since carrier yeast RNA was added to the $\mathrm{P} 32$-RNA product during isolation, the four $2^{\prime}\left(3^{\prime}\right)$-nucleoside monophosphates are found in each experiment. The exposed dark areas indicate the presence of $\mathrm{P}^{32}$.

Table 4

$\mathrm{P}^{32}$ CONTENT OF $2^{\prime}\left(3^{\prime}\right)$ NMP ISOLATED FROM $\mathrm{P}^{32}$-RNA SYNTHESIZED WITH POLY CU AS PRIMER

\begin{tabular}{c|c|c|c|c|c|c}
\hline \multirow{2}{*}{$\begin{array}{c}\text { Isolated } \\
2^{\prime}\left(3^{\prime}\right)-\text { ribo- } \\
\text { nucleotide }\end{array}$} & \multicolumn{4}{|c}{ Labeled triphosphate } \\
\cline { 2 - 7 } & Reaction No. 1 GTP 32 & \multicolumn{3}{c}{ Reaction No. 2 ATP 32} \\
\cline { 2 - 7 } & Sequence & cpm & Fraction & Sequence & cpm & Fraction \\
\hline Ap & ApG & 4,292 & 0.175 & ApA & 994 & 0.193 \\
Gp & GpG & 20,305 & 0.825 & GpA & 4,162 & 0.807 \\
Sum & & 24,597 & 1.000 & & 5,156 & 1.000 \\
\hline
\end{tabular}

Table 4, a ratio of G:A is obtained as follows:

$$
\begin{aligned}
0.175 g+0.825 g & =0.825 g+0.807 a \\
g / a & =4.6
\end{aligned}
$$


One can also assume that:

$$
\mathrm{g}+\mathrm{a}=1
$$

Similarly, the base composition may be derived for the RNA's synthesized in the presence of poly CA and poly CAU. In tise latter case, the equation involves three unknowns but may be readily solved since four equations are available.

Table 5

P32 CONTENT OF $2^{\prime}\left(3^{\prime}\right)$-NMP ISOLATED FROM P3Z-RNA SYNTHESIZED WITH POLY CA AS PRIMER

\begin{tabular}{c|c|c|c|c|c|c}
\hline \multirow{2}{*}{$\begin{array}{c}\text { Isolated } \\
2\end{array}$} & \multicolumn{6}{|c}{ Labeled triphosphate } \\
\cline { 2 - 7 } nucleotide & \multicolumn{3}{|c|}{ Reaction No. 1 GTP32 } & \multicolumn{3}{c}{ Reaction No. 2 UTP32 } \\
\cline { 2 - 7 } & Sequence & $\mathrm{cpm}$ & Fraction & Sequence & $\mathrm{cpm}$ & Fraction \\
\hline Up & UpG & 1,995 & 0.108 & UpU & 1,250 & 0.308 \\
Gp & GpG & 16,476 & 0.892 & GpU & 2,809 & 0.692 \\
Sum & & 18,471 & 1.000 & & 4,059 & 1.000 \\
\hline
\end{tabular}

Table 7 shows that the molar proportions of the complementary bases in the primer and product synthesized are nearly identical. Hence, poly C, poly CA, poly CU and poly CAU prime the synthesis of poly G, poly GU, poly GA and poly GUA respectively, where the molar proportions of GMP, UMP and AMP incorporated are determined by the molar proportions of cytidylate, adenylate and uridylate in the primer used.

No clear separation of the DNA- and RNA-dependent reactions has yet been achieved. In both $M$. lysodeikticus and E. coli extracts, all fractions containing RNA polymerase activity (including our 400-fold purified preparations), also catalyze RNA labeling with poly C or TYMV RNA as primers. Other evidence suggests, however, that separate enzymes are involved since a) the ratio of the two activities alters markedly as the extracts are purified with respect to the DNA primed reaction, b) temperature stability studies indicate that the rate of enzyme inactivation is not the same for the polydeoxy and polyribonucleotide primers, and c) poly $\mathrm{C}$ at high concentrations does not interfere with the DNA primed synthesis of RNA. Furth and coworkers ${ }^{8}$ have reported that E. coli RNA polymerase can be primed by deoxy poly T. One would expect that if one enzyme were involved, poly $U$ should also prime. In our hands, no labeled RNA is formed when E. coli extracts are incubated with $\mathrm{ATP}^{32}$ and pnly $U$ alone. Whether one or several enzymes are involved cannot be further resolved at this time.

The importance of cytidine as a constituent of the polyribonucleotide primer is emphasized by the inability of poly $A$ and poly $U$ alone to prime RNA synthesis by these extracts. However, Table 8 shows that both the AU copolymer and the 1:1 poly A + poly U complex prime the incorporation of labeled ATP or UTP. Analysis of the products formed in both cases (data not presented here) indicates that poly AU primes the synthesis of poly AU when both ATP and UTP are included in the reaction mixture, and that the poly $\mathrm{A}+$ poly $\mathrm{U}$ complex primes the synthesis of poly $\mathrm{A}$ and/or poly $\mathrm{U}$. It is important that in both cases the incorporation of labeled substrates 
Table 6

$\mathrm{P}^{32}$ CONTENT OF $2^{\prime}\left(3^{\prime}\right)$-NMP ISOLATEd FROM $\mathrm{P}^{32}$-RNA SYNTHESIZED WITH POLY CAU AS PRIMER

\begin{tabular}{|c|c|c|c|c|c|c|c|c|c|}
\hline \multirow{3}{*}{$\begin{array}{c}\text { Isolated } \\
2^{\prime}\left(3^{\prime}\right)-r i b o- \\
\text { nucleotide }\end{array}$} & \multicolumn{9}{|c|}{ Labeled triphosphate } \\
\hline & \multicolumn{3}{|c|}{ Reaction No. 1 GTP32 } & \multicolumn{3}{|c|}{ Reaction No. 2 ATP 32} & \multicolumn{3}{|c|}{ Reaction No. 3 UTP 32} \\
\hline & Sequence & $\mathrm{cpm}$ & Fraction & Sequence & $\mathrm{cpm}$ & Fraction & Sequence & cpm & Fraction \\
\hline Up & UpG & 2,471 & 0.126 & UpA & 484 & 0.190 & UpU & 1,387 & 0.217 \\
\hline Ap & ApG & 2,831 & 0.144 & ApA & 545 & 0.213 & $\mathrm{ApU}$ & 1,004 & 0.157 \\
\hline $\mathrm{Gp}$ & $\mathrm{GpG}$ & 14,310 & 0.730 & $\mathrm{GpA}$ & 1,524 & 0.597 & $\mathrm{GpU}$ & 3,993 & 0.626 \\
\hline Sum & & 19,612 & 1.000 & & 2,553 & 1.000 & & 6,384 & 1.000 \\
\hline
\end{tabular}

Table 7

COMPARISON OF BASE COMPOSITION DETERMINED FOR PRIMER ANI RNA PRODUCT

\begin{tabular}{|c|c|c|c|c|c|c|c|c|}
\hline \multirow{2}{*}{ Base } & \multicolumn{8}{|c|}{ Mole per cent composition } \\
\hline & $\begin{array}{c}\text { Primer } \\
\text { poly C }\end{array}$ & $\begin{array}{c}\text { Synthesized } \\
\text { RNA }\end{array}$ & $\begin{array}{l}\text { Primer } \\
\text { poly CA }\end{array}$ & $\begin{array}{c}\text { Synthesized } \\
\text { RNA }\end{array}$ & $\begin{array}{l}\text { Primer } \\
\text { poly CU }\end{array}$ & $\begin{array}{c}\text { Synthesized } \\
\text { RNA }\end{array}$ & $\begin{array}{l}\text { Primer } \\
\text { poly CAU }\end{array}$ & $\begin{array}{c}\text { Synthesized } \\
\text { RNA }\end{array}$ \\
\hline $\mathrm{C}$ & 100 & --- & 86.1 & -- & 82.7 & --- & 70.3 & --- \\
\hline A & --- & --- & 13.9 & --- & --- & 17.3 & 13.5 & 13.1 \\
\hline $\mathrm{U}$ & --- & --- & --- & 13.5 & 17.3 & --- & 16.2 & 14.7 \\
\hline $\mathrm{G}$ & --- & 100 & --- & 86.5 & --- & 82.2 & --- & 73.2 \\
\hline
\end{tabular}

* The determination of base composition by alkaline hydrolysis and isolation of the ribonucieoside monophosphates only, as was reported here, may result in significant error if the terminal residue is a base whose molar proportions in the chain are relatively small (e.g., $A$ or $U$ in poly CAU) since this residue will be lost as the nucleoside and the data kave not been corrected for this loss. 
Table 8

THE PRIMING OF NUCLEOTIDE INCORPORATION BY AMP- AND UMP-CONTAINING POLYMERS

\begin{tabular}{l|c|c|c}
\hline \multicolumn{1}{c|}{ Primers } & $\begin{array}{c}\text { Labeled } \\
\text { substrate }\end{array}$ & Additions & $\begin{array}{c}\text { Labeled substrate } \\
\text { incorporated into } \\
\text { RNA, m } \mu \text { moles }\end{array}$ \\
\hline Poly U & C $^{14-A T P}$ & None & 0.15 \\
Poly A & UTP32 & & 0.09 \\
Poly AU & & ATP & 1.35 \\
& & None & 4.20 \\
& & ATP & 2.46 \\
& \multirow{2}{*}{ Coly A + Poly U } & None & 2.24 \\
& & UTP & 0.74 \\
& & None & 1.73 \\
\hline
\end{tabular}

The reaction mixture and conditions of incubation was the same as indicated in Table 2 except that $30 \mu \mathrm{g}$ each of Poly U, Poly A and Poly AU were used as primers and $0.20 \mu \mathrm{m}$ of C 14 -ATP $\left(9.4 \times 10^{5} \mathrm{cpm} / \mu \mathrm{mole}\right)$ was used where indicated.

is not strictly dependent on a full complement of triphosphates as is the case with the cytidine copolymers. In addition, calculation of the base composition for the poly AU primed product by the isotope method described earlier, shows no relationship to the molar proportions of AMP and UMP in poly AU itself.

\section{DISCUSSION}

We feel that there must be some common denominator which relates the various experiments reported here. If separate enzymes are involved for the different RNA primers, then we must await. purification and a study of the different mechanisms involved. If the same enzyme which utilizes the poly $\mathrm{C}$-containing primers is also active with poly $\mathrm{AU}$ and the poly $\mathrm{A}+$ poly $\mathrm{U}$ complex, then one possible explanation may be the degree of order which these polymers exhibit.

In solution, at alkaline $\mathrm{pH}$ and at temperatures above $8^{\circ}$, poly $\mathrm{A}$ and poly $\mathrm{U}$ exhibit little or no ordered fine structures: $:^{21}$ poly A plus poly $U$, on the other hand, form a highly ordered structure. ${ }^{22}$ Evidence exists that AU copolymers have a reasonable degree of order and it has been postulated that there are intramolecular regions within the copolymer chain which are helical. ${ }^{21}$ Two types of ordered structure may exist in the AU copolymers a) the type represented by the poly $\mathrm{A}+$ poly $\mathrm{U}$ complex and $\mathrm{b}$ ) complementary chains of complex $\mathrm{A}-\mathrm{U}$ sequences. Under these circumstances the relationship between primer and product composition might well depend upon the nucleotides present in the reaction mixture, as well as their concentrations. If only the or dered regions prime, then we can readily understand why the base composition of the poly AU primer bears no relationship to the composition of the product formed.

If ordered structure is important for priming, why then should poly $\mathrm{C}$ and the cytidine-containing copolymers function so well in this capacity? In a manner not understood at present, it may be possible for poly $\mathrm{C}$ and other cytidine copolymers to establish a degree of order (e.g., perhaps by interaction with the enzyme), which the homopolymers poly A, poly $U$ and poly I can- 
not produce alone. These experiments not only demonstrate the synthesis of RNA from polyribonucleotide primers but also that cytidine holds a central position for the type of priming observed. The phenomenon obviously requires further understanding which our present data do not afford. Although the explanation presented here for the data obtained must be regarded as speculative, it provides a basis for further experimentation.

The authors wish to acknowledge the many helpful discussions with Drs. E. P. Geiduschek and R. Haselkorn in preparation of this manuscript.

\section{LITERATURE CITED}

1. Grunberg-Manago, M., and S. Ochoa. J. Am. Chem. Soc., 77:3165, 1955.

2. Weiss, S. B., and L. Gladstone. J. Am. Chem. Soc., 81:4118, 1959.

3. Weiss, S. B. Proc. Nat. Acad. Sci., 46:1020, 1960.

4. Hurwitz, J., A. Bresler, and R. Diringer. Biochem. and Biophys. Research Communs., 3: $15,1960$.

5. Stevens, A. Proc. Nat. Acad. Sci., 3:92, 1960.

6. Weiss, S. B., and T. Nakamoto. J. Biol. Chem., 236:PC18, 1961.

7. Ochoa, S., and L. A. Heppel. In The Chemical Basis of Heredity, ed. W. D. McElroy and B. Glass, Baltimore: Johns Hopkins Press, 1957, p. 615.

8. Furth, J. J., J. Hurwitz, and M. Goldman. Biochem. and Biophys. Research Communs., $4: 362,1961$.

9. Geiduschek, E. P., T. Nakamoto, and S. B. Weiss. Proc. Nat. Acad. Sci., 47:1405, 1961.

10. Chung, C. W., H. R. Mahler, and M. Enrione. J. Biol. Chem., 235:1448, 1960.

11. Straus, D. B., and E. Goldwasser. J. Biol. Chem., 236:849, 1961.

12. Burdon, R. H., and R. M. S. Smellie. Biochim. et Biophys. Acta., 51:153, 1961.

13. Reddi, K. K. Presented at the 98th meeting of the National Academy of Sciences, 1961.

14. Hurwitz, J., J. Furth, M. Anders, P. J. Ortiz, and J. T. August. In Cold Spring Harbor Symposia on Quantitative Biology, vol. 26, 1961, p. 91.

15. Tener, G. M. J. Am. Chem. Soc., 83:159, 1961.

16. Steiner, R. F., and R. F. Beers. In Polynucleotides, Amsterdam: Elsevier Publishing Co., 1961, p. 374.

17. Gierer, A., and G. Schramm. Nature, 177:702, 1956.

18. Weiss, S. B., and T. Nakamoto. Proc. Nat. Acad. Sci., 47:694, 1961.

19. Weiss, S. B., and T. Nakamoto. Proc. Nat. Acad. Sci., 47:1400, 1961.

20. Josse, J., A. D. Kaiser, and A. Kornberg. J. Biol. Chem., 236:864, 1961.

21. Steiner, R. F., and R. F. Beers. In Polynucleotides, Amsterdam: Elsevier Publishing Co., 1961, p. 189.

22. Warner, R. Ann. N. Y. Acad. Sci., 69:314, 1957. 


\section{THE SECONDARY STRUCTURE OF COMPLEMENTARY RNA ${ }^{*}$}

\section{By}

E. P. Geiduschek, ${ }^{\ddagger}$ J. W. Moohr ${ }^{* *}$ and S. B. Weiss

The existence of enzymes which catalyse the copolymerisation of ribonucleoside triphosphates in the presence of a DNA ${ }^{\dagger \dagger}$ primer is well established. ${ }^{1-5}$ In particular it has been shown that the RNA polymerase of M. lysodeikticus catalyses the formation of an RNA product which has the overall composition (U substituting for $\mathrm{T}$ ) and nearest neighbor sequence of its DNA template and which contains polynucleotide sequences complementary to its DNA. ${ }^{5-7}$ From the extent of complexing of bacteriophage T2 DNA to its complementary RNA we had tentatively concluded that both DNA strands must serve as a template for C-RNA synthesis. ${ }^{7}$ In that case, CRNA could be self-complementary and, under certain circumstances, might exhibil secondary structure properties like those of native, helical DNA. The experiments described below show this to be the case.

During the past decade, the physical chemistry of the natural and synthetic polynucleotides has been the subject of intensive experimentation. As a result a wide variety of criteria is available for assessing the secondary structure properties of C-RNA. The most restrictive of these criteria is that of irreversible denaturation. Only highly ordered polynucleotides of complex sequence can be caused to undergo such irreversible changes of secondary structure. ${ }^{8}$ In fact, prior to the work reported here, only DNA had been shown to fall into this exclusive category. $¥$ Irreversible changes in secondary structure result in readily detectable changes of optical properties, reactivity of functional groups and susceptibility to enzymatic hydrolysis. The demonstration of a DNA-like conformation in C-RNA has accordingly been constructed around a variety of

\footnotetext{
assays of irreversible denaturation.

*This report appears in the Proc. Nat. Acad. Sci., 48:1078 1962 )

$\dagger$ Investigation supported in part by funds from the U.S. Public Health Service (Grant C-5007), and the Joseph and Helen Regenstein Foundation.

${ }^{\ddagger}$ Committee on Biophysics, University of Chicago.

** Department of Biochemistry, University of Chicago.

${ }^{\dagger}$ The following abbreviations are used: $\mathrm{A}$, adenine; $\mathrm{U}$, uracil; $\mathrm{G}$, guanine; $\mathrm{T}$, thymine; $\mathrm{C}$, cytosine; DNA, sodium deosyribonucleate; RNA, sodium ribonucleate; C-RNA, "complementary" RNA; TMV, tobacco mosaic virus; ATP, adenosine -5' triphosphate; GTP, guanosine $-5^{\prime}$ triphosphate; Tris, tris(hydroxymethyl)aminomethane; EDTA, disodium ethylenediaminetetraacetate; TCA, trichloracetic acid; RNase, ribonuclease.

柿Contrary examples are highly ordered complementary ribopolynucleotide complexes such as poly A + poly U, poly I + poly C and polydeoxyribo AT and GC, which undergo highly cooperative helix-coil transitions that are completely reversible; they lack the complex nucleotide sequences which make the re-establishment of correctly aligned complementary sequences an improbable event. The complex polynucleotides such as TMV RNA, bacteriophage $\phi \times 174$ DNA and poly (AGUC) on the other hand, lack the complementarity that would allow a highly ordered secondary structure to exist. These latter polynucleotides do give ample evidence of intramolecular purine-pyrimidine interactions, and undergo relatively broad secondary structure transitions under a variety of circumstances. ${ }^{8}$ Evidently the interactions involve sufficiently short nucleotide sequences so that irreversibility does not occur. If these disordered polynucleotides at any time possess a unique biologically significant conformation, it is not one that has thus far been distinguished by enzymological or physical-chemical criteria.
} 


\section{EXPERIMENTAL METHODS}

C-RNA was enzymatically synthesized on a bacteriophage T2 DNA template by a method described previously. ${ }^{6,7}$ Primer DNA and synthesized RNA were separated from protein by phenol extraction. 9 The combined nucleic acids were precipitated by cetyl trimethylammonium bromide or ethanol, redissolved and separated from each other by 48-72 hours' gradient centrifugation in 8.4 molal $\mathrm{CsCl}$ at $20-25^{\circ} \mathrm{C}$. At the end of that time, the RNA was collected in the densest part of the gradient, precipitated with alcohol, redissolved in $0.01 \mathrm{M} \mathrm{NaCl}$ at room temperature and dialyzed against $0.01 \mathrm{M} \mathrm{NaCl}$. Samples were stored at $-20^{\circ} \mathrm{C}$ in this solvent. Details have been presented previously. ${ }^{7} \mathrm{P}^{32}$-C-RNA was made with ATP or GTP, labeled in the ribose-proximal phosphate.

Bovine pancreatic ribonuclease and formaldehyde (reagent grade, 37 per cent) were used without further purification.

UV absorbance was measured as a function of temperature in thermostated Beckman DU or Unicam spectrophotometers, using $4.3 \times 10 \times 38 \mathrm{~mm}$ stoppered quartz cells. Changes of concentration resulting from evaporation at the highest temperatures were followed by frequent reweighing, and absorbances were appropriately corrected.

The reaction of T2-C-RNA with formaldehyde was also followed spectrophotometrically. RNA and borate buffer were mixed in the stoppered cuvette to give $0.01 \mathrm{M}$ borate of $\mathrm{pH} 8.4$ to $8.5,0.01 \mathrm{M} \mathrm{NaCl}$ and the absorbance was measured at $37^{\circ} \mathrm{C}$ against the appropriate reference buffer. Aliquots of 10 per cent $\mathrm{CH}_{2} \mathrm{O}$ in $0.1 \mathrm{M}$ borate $\mathrm{pH} 8.4-8.5$ were then added to the RNA solution and reference buffer, mixed, and the cuvettes returned to the $37^{\circ} \mathrm{C}$ spectrophotometer as rapidly as possible. After $6-8$ hours at $37^{\circ} \mathrm{C}$ the $\mathrm{RNA}-\mathrm{CH}_{2} \mathrm{O}$ solutions were heated at $80^{\circ} \mathrm{C}$ for 10 minutes in a stoppered vial, cooled rapidly and remeasured at $37^{\circ} \mathrm{C}$.

The sedimentation constants of four T2-C-RNA samples were determined under conditions that would ensure complete dissociation of secondary structure-i.e., in 1 per cent $\mathrm{CH}_{2} \mathrm{O}$, $0.08 \mathrm{M} \mathrm{NaCl}, 0.01 \mathrm{M}$ borate buffer, $\mathrm{pH} 8.3$ after 10 minutes' heating to $80^{\circ} \mathrm{C}$ in this solvent (Table 1). Solutions containing 0.005 per cent RNA were centrifuged at $44,770 \mathrm{rpm}, 25^{\circ} \mathrm{C}$ in a Spinco Model $\mathrm{E}$ analytical ultracentrifuge. The conventional UV absorption camera was used with an auxiliary Corning No. 9864 filter. Densitometric traces were made on a Joyce-Loebl recording microdensitometer. The sedimentation constants $\left(\mathrm{S}_{20, w}\right)$ recorded in Table 1 correspond to the rates of migration of the midpoints of absorbance boundaries. Values have been corrected to the viscosity of water at $20^{\circ} \mathrm{C}$.

\section{RESULTS AND DISCUSSION}

The first indication that T2-C-RNA purified by $\mathrm{CsCl}$ density gradient centrifugation might, in part, have a highly ordered secondary structure came from measurements of the absorbancetemperature relation. Figure 1 shows such an experiment. The first heating curve (1) of this T2-C-RNA (sample 10-24) in $5 \times 10^{-3} \mathrm{M} \mathrm{NaCl}, 10^{-3} \mathrm{M}$ phosphate $\mathrm{pH} 7.1,10^{-4} \mathrm{M}$ versene has two distinct portions: between 15 and $40^{\circ} \mathrm{C}$ there is a gradual increase in absorbance (at $260 \mathrm{~m} \mu$; $\mathrm{A}_{260}$ ); near $55^{\circ} \mathrm{C}$ the temperature dependence becomes very much greater, and this steep portion of the heating curve ends at about $70^{\circ} \mathrm{C}$. If one takes the cuvette which has been heated to $83^{\circ} \mathrm{C}$, cools it in ice and reheats, a very shallow absorbance-temperature curve $\left(\mathrm{A}^{(2)}(\mathrm{T})\right.$; Figure 1 , Curve 2) is obtained. The absorbance at $25^{\circ} \mathrm{C}$ has been irreversibly increased by heating to $83^{\circ} \mathrm{C}$. This result leads quite naturally to the following interpretation of the initial heat- 
ing curve (Figure 1, Curve 1). The T2-C-RNA sample contains ordered (helical, DNA-like) and disordered (denatured, TMV-RNA-like) polynucleotide. The gradual increase of $\mathrm{A}$ between 15 and $35^{\circ} \mathrm{C}$ is due to the dissociation of disordered C-RNA secondary structure. At these temperatures ordered C-RNA secondary structure is stable; its dissociation occurs mainly at $50-70^{\circ} \mathrm{C}$. A simple manipulation permits the contribution of these two conformations to the absorbancetemperature curve to be estimated. The contribution of disordered C-RNA (Figure 1, Curve 3) can then be subtracted from the total absorbance (Curve 1) to yield the absorbance-temperature dependence of ordered C-RNA (Curve 4). For four samples, the fraction of nucleotides contained in ordered, helical, DNA-like arrays $\left(f_{h}\right)$, ranges from 0.45 to 0.66 (Table 1). Details of the calculations are given in footnote.

Table 1

PROPERTIES OF T2-C-RNA SECONDARY STRUCTURE

\begin{tabular}{|c|c|c|c|c|c|c|c|}
\hline \multirow{2}{*}{ Prep. } & \multirow{2}{*}{$S_{20, w}$} & \multicolumn{4}{|c|}{$\begin{array}{l}\text { Fraction of nucleotide in highly } \\
\text { ordered form }\left(\mathrm{f}_{\mathrm{h}}\right)\end{array}$} & \multirow{2}{*}{$\mathrm{T}_{1 / 2, \mathrm{~d}^{\mathrm{a}, \mathrm{b}}}$} & \multirow{2}{*}{$\mathrm{T}_{1 / 2, \mathrm{i}^{\mathrm{a}, \mathrm{c}}}$} \\
\hline & & $\begin{array}{l}\text { Heat } \\
\text { denat. }\end{array}$ & $\mathrm{CH}_{2} \mathrm{O}$ & $\begin{array}{l}\text { DNA } \\
\text { hybrid }\end{array}$ & RNase & & \\
\hline $9-1$ & 4.3 & 0.60 & -- & -- & --- & 63 & -- \\
\hline $10-15$ & 4.6 & 0.45 & 0.42 & -- & -- & 63 & -- \\
\hline $10-24$ & 4.1 & 0.56 & 0.50 & -- & -- & 61 & -- \\
\hline 11 & 4.3 & 0.66 & 0.58 & -- & $\cdots$ & 65 & -- \\
\hline $\mathrm{P}^{32}$ & -- & --- & -- & 0.74 & 0.69 & --- & 61 \\
\hline T2 DNA & $(56)^{d}$ & 1.0 & -- & --- & -- & 59.5 & -- \\
\hline
\end{tabular}

${ }^{\mathrm{a}}$ Measured in $0.005 \mathrm{M} \mathrm{NaCl}, 10^{-3} \mathrm{M}$ Phosphate, $\mathrm{pH} 7.1,10^{-4} \mathrm{M}$ EDTA.

${ }^{\mathrm{b}}$ Midpoint denaturation temperature of the ordered form of T2-C-RNA. This is calculated. from thermal transition data by the procedure given in footnote 3 , and shown in Figure 1.

${ }^{\mathrm{C}}$ Temperature at which the irreversible denaturation of C-RNA is one-half completed (Figure 4).

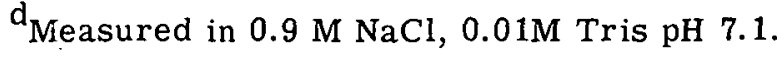

The reaction of $\mathrm{T} 2-\mathrm{C}-\mathrm{RNA}$ with $\mathrm{CH}_{2} \mathrm{O}$ proceeds in a manner that leads qualitatively and quantitatively to the same interpretation. Some of the T2-C-RNA amino groups react with 1 per cent $\mathrm{CH}_{2} \mathrm{O}$ at $37^{\circ} \mathrm{C}, \mathrm{pH} 8.5$. The rest behave like amino groups in native DNA in that they are made available to $\mathrm{CH}_{2} \mathrm{O}$ reaction by heating at $80^{\circ} \mathrm{C}$ for 10 minutes (Figure 2). UV absorption

* The temperature dependence of $\mathrm{A}$ for the disordered polynucleotide should be the same as curve 2, Figure 1 . Let $\mathrm{g} \mathrm{A}(2)$ (I5) represent the absorbance of the original sample (at $15^{\circ} \mathrm{C}$ ) which is contributed by disordered polynucleotide. Then according to the interpretation presented in the text, $\mathrm{g}$ is determined by the requirement that for $\mathrm{T} 35^{\circ} \mathrm{C}$,

$$
g\left[A^{(2)}(T)-A^{(2)}(15)\right]=A^{(1)}(T)-A^{(1)}(15)=A^{(3)}(T)-A^{(3)}(15)
$$

i.e., that curves 1 and 3 coincide over the range $15-35^{\circ} \mathrm{C}$. For sample $10-24, \mathrm{~g}=0.44$ satisfies that requirement. Curve (4), the difference between curves (1) and (3), is the calculated absorbance-temperature curve of ordered C-RNA. The absorbance contributed by ordered C-RNA at $25^{\circ} \mathrm{C}$ is then $A_{h}=A(1)(25)-g A(2)(25)$, and the mole fraction of C-RNA in the ordered conformation at $25^{\circ} \mathrm{C}$ is $\mathrm{f}_{\mathrm{h}}=1 \div \mathrm{g}$ (estimated reliability \pm 0.05 ). 
spectra show a shift of the wave length of maximum absorbance from 258.5 to $260 \mathrm{~m} \mu$ at $37^{\circ} \mathrm{C}$ and a further shift to $262 \mathrm{~m} \mu$ after heating to $80^{\circ} \mathrm{C}$. Once again, the relative magnitudes of the absorbanc changes can be used to calculate $f_{h}$, the fraction of nucleotide contained in DNA-like arrays. Detailof the calculation are given in footnote. ${ }^{*}$ For the samples shown in Table $1, f_{h}$ ranges from 0.42 to

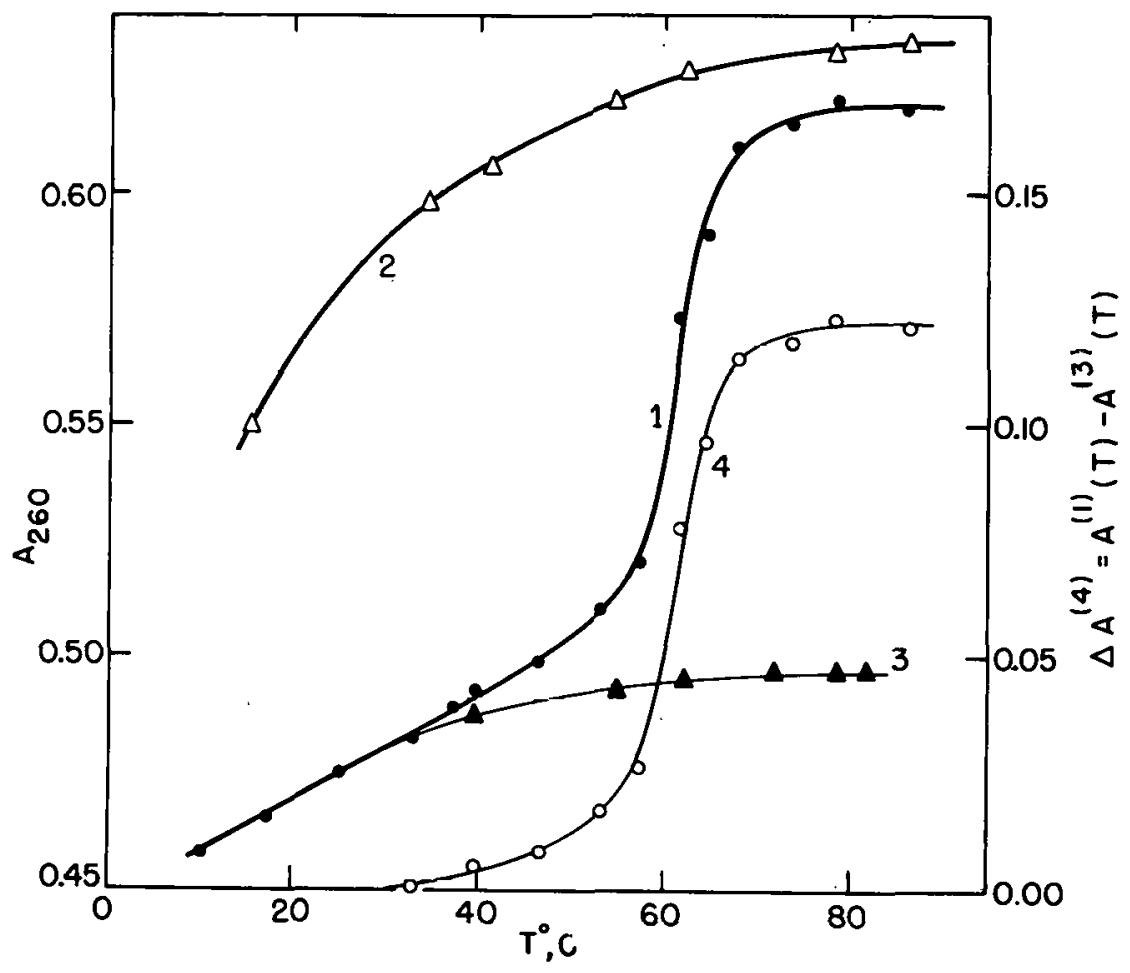

Figure 1. Temperature dependence of absorbance at 260 $\mathrm{m} \mu\left(\mathrm{A}_{260}\right)$ of C-RNA (sample 10-24) in $5 \times 10^{-3} \mathrm{M} \mathrm{NaCl}$, 10-3 M phosphate, 10-4 M EDTA pH 7.

Curve 1: Initial heating curve $(A(1)(T))$.

Curve 2: The solution from 1 has been cooled rapidly from

$83^{\circ} \mathrm{C}$ to $15^{\circ} \mathrm{C}$ and is reheted $(\mathrm{A}(2)(\mathrm{T}))$.

Curve 3: $A^{(3)}(T)=A(1)(15)+g A^{(2)}(T)-A(2)(15)$.

Curves 3 and 1 coincide over the temperature range 15 $35^{\circ} \mathrm{C}$ for $\mathrm{g}=0.44$.

Curve 4: $A(4)=A(1)(T)-A^{(3)}(T)$ (Right hand scale).

\footnotetext{
* The absorbance change upon heating the $\mathrm{CH}_{2} \mathrm{O}$ solution of $\mathrm{C}-\mathrm{RNA}$ to $80^{\circ} \mathrm{C}\left(\mathrm{a}^{\Delta}\right.$, Figure 2) is assumed to be due to the combined effects of denaturation and formylation. Each of these ef fects changes the absorbance: 1) Unstacking the nucleotide pairs increases absorbance by approximately 45 per cent at $250-280 \mathrm{~m} \mu$. 2) The difference spectrum for reaction of a T2-mimetic mixture of adenine, guanine and cytosine with $\mathrm{CH}_{2} \mathrm{O}$ has its isosbestic points near $255 \mathrm{~m} \mu$ and maximum at $275 \mathrm{~m} \mu .10$ We estimate that the combined effects of denaturation and formylation lead to fractional absorbance increases $r$, of $0.45,0.49$ and 0.54 at 255,258 and $260 \mathrm{m \mu}$ respectively. The absorbance that ordered C-RNA contributes to the solution $\left(A_{h}\right)$ is therefore a $/ r$. $f_{h}$ is calculated from $A_{h}$ and $A_{O}$, the absorbance before $\mathrm{CH}_{2} \mathrm{O}$ addition, as

$$
f_{h}=\frac{(1+r) A_{h}}{A_{o}+A_{h}}=\frac{1+r}{r} \quad \frac{a^{\Delta}}{A_{o}+a^{\Delta}}
$$

For sample 11 the values of $f_{h}$ calculated in this way at 255,258 and $260 \mathrm{~m} \mu$ are $0.57,0.59$ and 0.55 respectively. Averaged values of $f_{h}$ are listed in Table 1 . They are consistently lower than $f_{h}$ calculated from the thermal transition data (e.g. Figure 1 ).
} 
0.58. The formaldehyde reaction values of $f_{h}$ are consistently lower than $f_{h}$ calculated from thermal transition data (e.g., Figure 1). This may be due to a small part of the ordered C-RNA reacting with 1 per cent $\mathrm{CH}_{2} \mathrm{O}$ during the $6-8$ hours at $37^{\circ} \mathrm{C}$ that precede the heating.

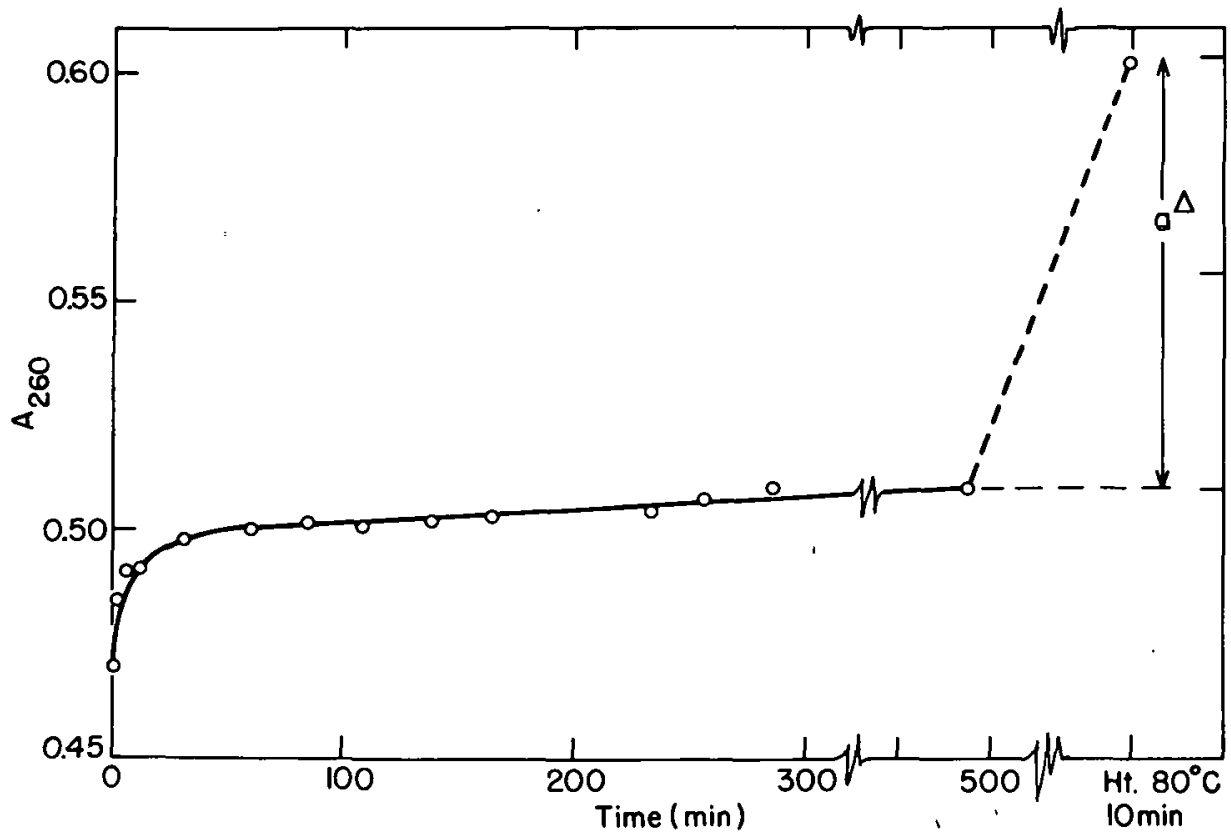

Figure 2. Absorbance of C-RNA (sample 10-24) in 1 per cent formaldehyde at $37^{\circ} \mathrm{C}, \mathrm{pH} 8.5$ as a function of time. After 480 minutes at $37^{\circ} \mathrm{C}$ the sample was heated to $80^{\circ} \mathrm{C}$ for 10 minutes and remeasured at $37^{\circ} \mathrm{C} . \mathrm{a}^{\Delta}$ : absorbance increase on heating to $80^{\circ} \mathrm{C}$.

T2-C-RNA which has been purified in a $\mathrm{CsCl}$ density gradient shows a remarkable resistance to digestion by pancreatic RNase (Figure 3, Curve 1). That this property is associated with RNA configuration rather than RNA composition is shown by the dramatic correlation between irreversible denaturation and susceptibility to hydrolysis (Figure 3). Clearly, the production of acid-soluble fragments by pancreatic RNase constitutes a simple and extremely sensitive assay of C-RNA secondary structure. We have employed it in this manner in following the irreversible thermal denaturation of $\mathrm{P}^{32}$ labeled T2-C-RNA. Figure 4 shows an irreversibility assay of $\mathrm{C}$-RNA secondary structure, the RNase digestion being performed at $37^{\circ} \mathrm{C}$ after brief heating to a specified temperature. Accordingly, no changes in the release of acid soluble $\mathrm{P}^{32}$ are observed between 25 and $40^{\circ} \mathrm{C}$ (contrast Figure 1, Curve 1), since ordered C-RNA is not affected in this temperature range, and since only the irreversible structure changes of ordered C-RNA are detected in the RNase assay. It should be noted that for such small polynucleotide molecules as these $\left(\mathrm{S}_{20, \mathrm{w}}\right.$, Table 1$)$, equilibrium and irreversibility transition assays do not differ appreciably; ${ }^{11}$ the corresponding midpoint transition temperatures $\left(\mathrm{T}_{1 / 2}\right.$, Table 1 ; Figure 4; Figure 1, Curve 4) are, indeed, very similar.

If $\mathrm{T} 2-\mathrm{C}-\mathrm{RNA}$ preparations isolated by centrifugation in a $\mathrm{CsCl}$ density gradient are partly ordered, then the ability to form DNA-C-RNA hybrids with denatured T2-DNA should depend on the thermal history of the C-RNA. This is found to be the case. In the experiment shown in Fig- 


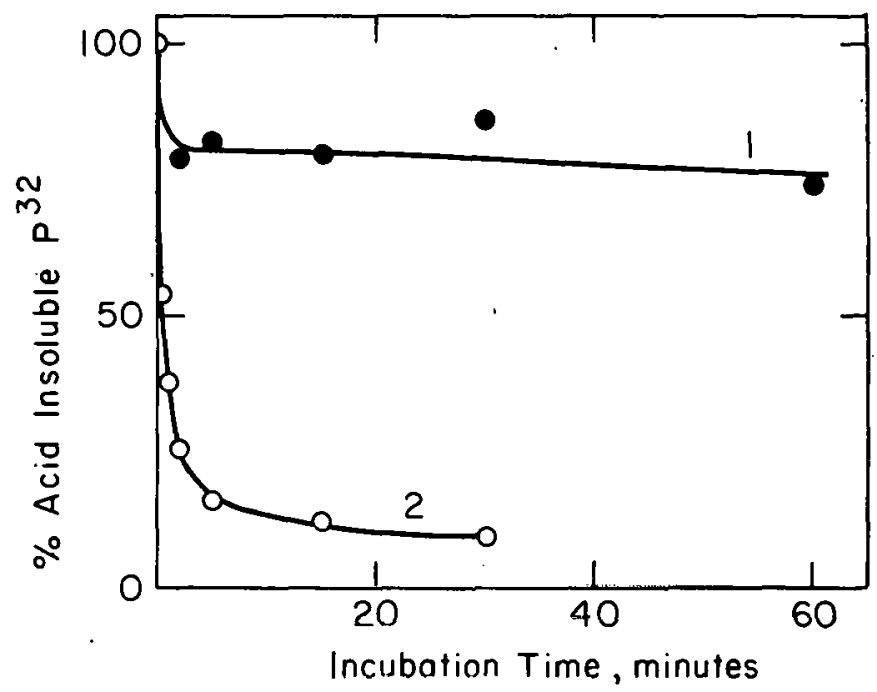

Figure 3. Release of TCA-soluble nucleotides from P32-C-RNA by pancreatic RNase at $25^{\circ} \mathrm{C}$.

Curve 1: T2-C-RNA purified by $\mathrm{CsCl}$ gradient centrifugation.

Curve 2: Same, after heating RNA at $100^{\circ} \mathrm{C}$ for 10 minutes in $0.01 \mathrm{M} \mathrm{NaCl}$.

Conditions of RNase assay: The complete system contained $3 \mu$ moles of $\mathrm{MgCl}_{2} ; 50 \mu$ moles of Tris, $\mathrm{pH} 7.8 ; 1.8 \mu \mathrm{g}$ of $\mathrm{P}^{32}-\mathrm{C}-\mathrm{RNA}\left(3.33 \times 10^{3} \mathrm{cpm}\right.$ per $\mu \mathrm{g}$ and $0.05 \mu \mathrm{g}$ of ribonuclease in a total volume of $0.60 \mathrm{ml}$. This mixture was incubated at $37^{\circ}$. At appropriate time intervals, $0.10 \mathrm{ml}$ aliquots were removed and added to $100 \mu \mathrm{g}$ of DNA which served as a carrier. The reaction was stopped by the addition of 50 per cent TCA to give a final concentration of 10 per cent, and the mixture placed in ice. The acid-insoluble material was collected by filtration through membrane filters ("Millipore," Type HA, $0.45 \mu$ pore diameter) and washed 3 times with successive $5 \mathrm{ml}$ portions of cold 5 per cent TCA. The filters were then dried in planchets and the radioactivity content determined in a gas flow counter.

ure 5, denatured C-RNA forms four times as much hybrid upon annealing as C-RNA which has not been heated. Moreover, this experiment and the RNase digestion experiment on the same sample are quantitatively consistent: the $\mathrm{P}^{32}-\mathrm{C}$-RNA preparation is 3.8 times more effective in complexing T2-DNA (under the conditions of the annealing experiment) after denaturation. ${ }^{*}$

It is digested 3.3 times more readily by RNase after denaturation (Figure 4); accordingly, one estimates $f_{h}=0.74$ from the DNA hybrid experiment and $f_{h}=0.69$ from the RNase assay.

Several lines of evidence, as we have seen, suggest that part of our T2-complementary RNA has a secondary structure with stability and other properties very similar to those of ordered, helical DNA. If C-RNA secondary structure were also determined by the interaction of

* It has already been shown that when T2 DNA and T2-C-RNA are heated together to $100^{\circ} \mathrm{C}$ and quenched, no complex formation cap be detected in a $\mathrm{CsCl}$ density gradient. Such complexes form during the "annealing" at $41^{\circ} \mathrm{C} .7,12$ The reheating of T2 DNA together with the C-RNA, therefore, in no way complicates the interpretation of this experiment. 
two complementary polynucleotide chains, then heat-denatured T2-C-RNA should be capable of being "annealed" at moderately high temperatures, and the rate should depend on concentration. ${ }^{13,14}$ Both of these expectations are borne out. At $55^{\circ} \mathrm{C}$ in $0.1 \mathrm{M} \mathrm{NaCl}$ there is a rapid conversion of heat denatured T2-C-RNA to the RNase-resistant, ordered form. In fact, this "annealed" C-RNA has a higher fraction of ordered nucleotide than the original unheated sample. At RNA concentrations of 200 and $50 \mu \mathrm{g} / \mathrm{ml}$ the half times of the reaction are 15 and 60 minutes respectively (Figure 6). The second-order dependence on concentration may be fortuitous, since

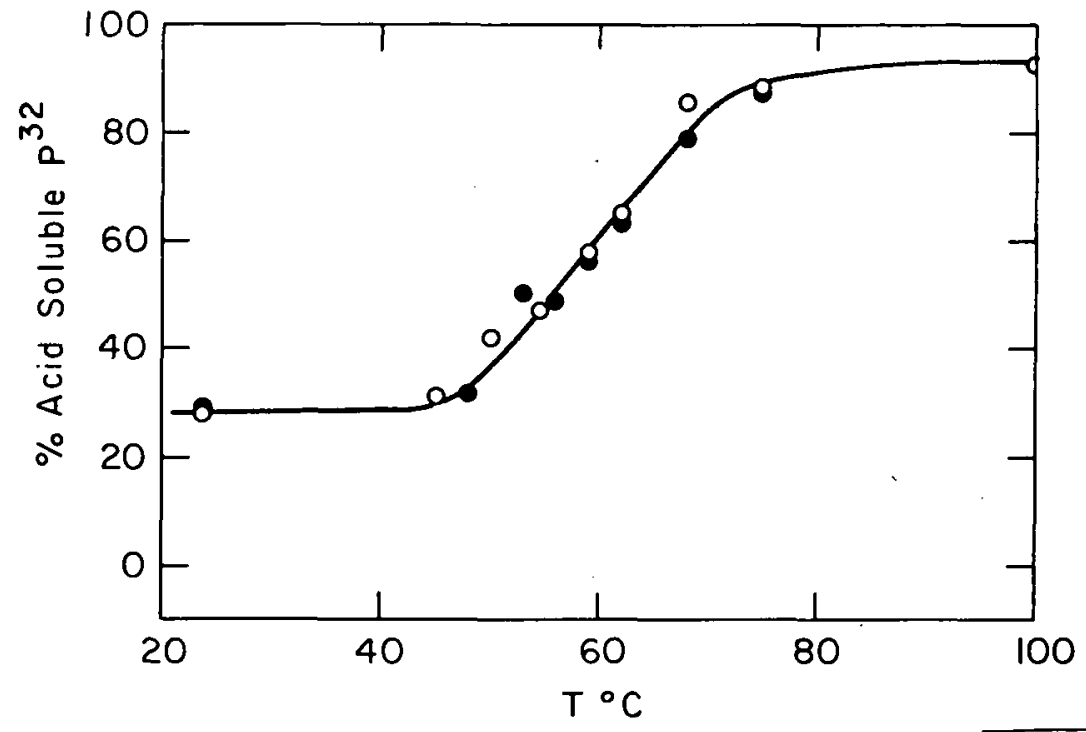

Figure 4. Irreversible denaturation of C-RNA in $5 \times 10^{-3}$ $\mathrm{M} \mathrm{NaCl}, 10^{-3} \mathrm{M}$ phosphate, $10^{-4} \mathrm{M}$ EDTA as detected by susceptibility to pancreatic RNase digestion. Two separale experiments ( $\bullet$ and 0 ) are shown. Heating Procedure: The C-RNA solution $(15 \mu \mathrm{g} / \mathrm{ml})$ is maintained at a given temperature for 10 minutes. A 0.10 $\mathrm{ml}$ aliquot is removed and the remaining solution is equilibrated at the next highest temperature. RNase Assay: The $0.10 \mathrm{ml}$ aliquot is cooled and made up to a total volume of $1.0 \mathrm{ml}$ with $0.12 \mathrm{ml} \mathrm{M}$ Tris $\mathrm{pH} 7.8$, $0.06 \mathrm{ml} 0.1 \mathrm{M} \mathrm{MgCl}_{2}$ and water. Two aliquots are then taken. One $0.45 \mathrm{ml}$ portion is digested with $0.6 \mu \mathrm{g}$ RNase for 10 minutes at $37^{\circ} \mathrm{C}$, and acid precipitable $\mathrm{P}^{32}$ is determined. The other aliquot serves as a control of acid precipitable $\mathrm{p}^{32}$ before enzymatic digestion. The percentage of $\mathrm{P}^{32}$ rendered acid soluble by RNase digestion is shown as a function of the heating temperature.

the time dependence of the annealing process deviates from second order. Such deviations could well arise from heterogeneity among the relatively small C-RNA molecules or from the presence of slightly non-stoichiometric proportions of complementary polynucleotide.

It is important to discover whether C-RNA is synthesized in the highly ordered, DNA-like form. The RNase assay is well suited to deciding this point. We find that C-RNA is very susceptible to RNase hydrolysis at the beginning of its purification and that susceptibility is not greatly increased at this stage by heating at $100^{\circ} \mathrm{C}$. For example, when the mixture of RNA and DNA remaining after phenol extraction of the polymerase reaction mixture is digested with RNase 


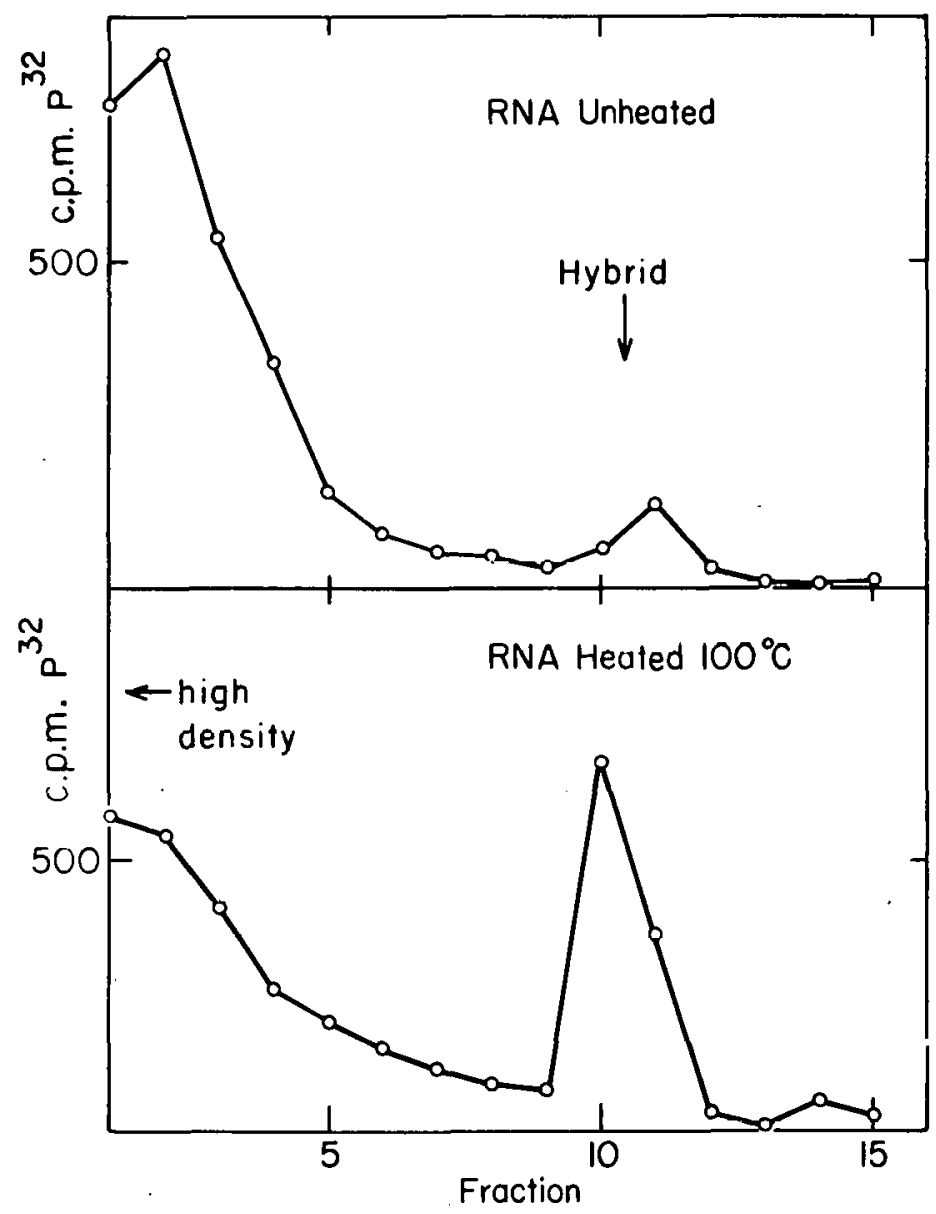

Figure 5. Dependence of complex formation between P32-T2-C-RNA and denatured T2-DNA upon RNA secondary structure.

Method: T2-DNA is denatured by he ating at $100^{\circ} \mathrm{C}$ for 10 minutes in $0.01 \mathrm{M} \mathrm{NaCl}$, and quenched. $\mathrm{Ap}-$ proximately $100 \mu \mathrm{g}$ DNA and $15 \mu \mathrm{g} \mathrm{P} \mathrm{P}^{32}-\mathrm{T} 2-\mathrm{C}-\mathrm{RNA}$ are mixed in a total volume of $0.6 \mathrm{ml}$, adjusted to $0.6 \mathrm{M} \mathrm{CsCl}$ and divided into 2 parts. One portion of this RNA-DNA mixture is then reheated to $100^{\circ} \mathrm{C}$ for 15 minutes and quenched. Both samples are "annealed" at $41.3^{\circ} \mathrm{C}$ for 8 hours. They are then centrifuged for 72 hours in $3 \mathrm{ml}$ of 8.4 molal $\mathrm{CsCl}$ at $25^{\circ} \mathrm{C}, 35600 \mathrm{rpm}$. Fractions are collected and TCA insoluble $\mathrm{P}^{32}$ is measured as previously described. 7 C-RNA complexed to T2-DNA ("hybrid") appears as a discrete peak of $\mathrm{P} 32$ radioactivity in the less dense portion of the gradient.

$(0.6 \mu \mathrm{g} / \mathrm{ml})$ for 15 minutes at $37^{\circ} \mathrm{C}, 82$ per cent of the C-RNA- $\mathrm{P}^{32}$ is rendered acid soluble. Heating to $100^{\circ} \mathrm{C}$ and rapid cooling renders 92 per cent of the $\mathrm{P}^{32}$ acid soluble after the same enzymatic digestion. Evidently T2-C-RNA acquires its ordered secondary structure during its lengthy isolation, presumably by intermolecular interactions of the "annealing" type. A different experiment provides independent corroborative evidence on this point. The C-RNA that has been made on a heterogeneous animal DNA primer should also be relatively heterogeneous. If 
the above interpretation is generally valid and C-RNA is synthesized in a disordered configuration, then any heterogeneous $\mathrm{C}-\mathrm{RNA}$ that has been isolated by the $\mathrm{CsCl}$ procedure should be less highly ordered than similarly purified homogeneous C-RNA, since secondary structure formation by intermolecular "annealing" is less successful in heterogeneous nucleic acids. ${ }^{14}$ A preparation of salmon-C-RNA was in fact found to have an $f_{h}$ of approximately $0.15\left(\mathrm{CH}_{2} \mathrm{O}\right.$ assay; data not shown).

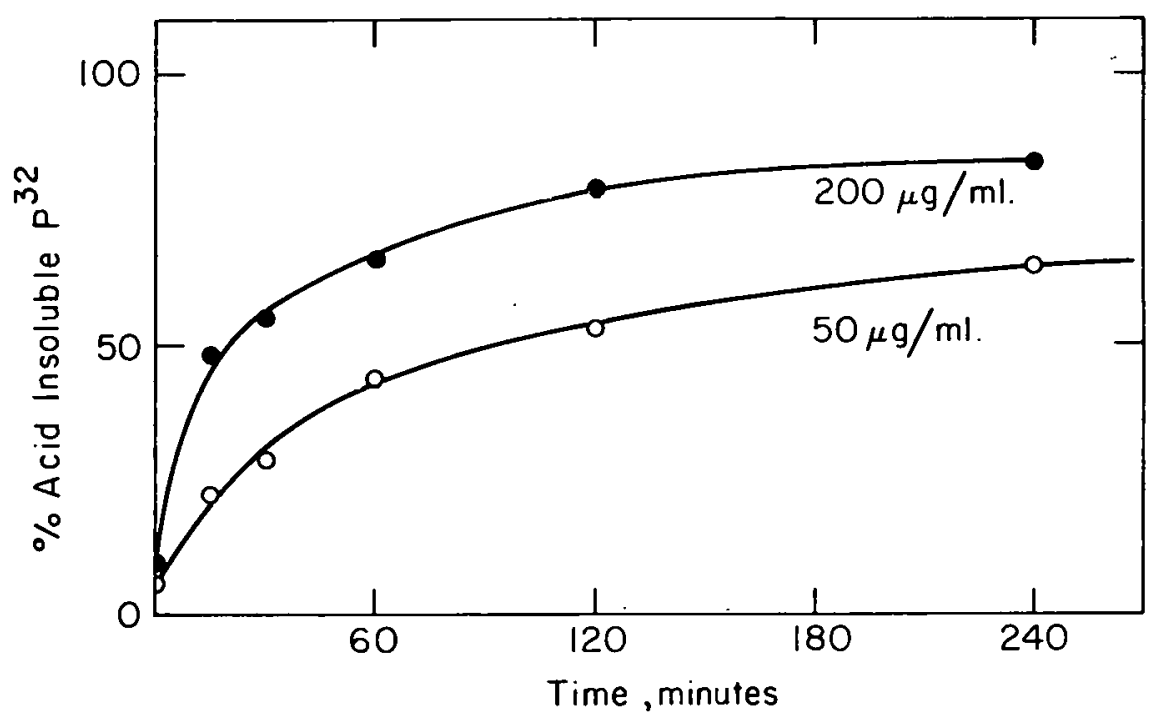

Figure 6. Re-establishment of C-RNA secondary structure after thermal denaturation.

Ordinate: fràction of RNA not converted to acid soluble form by incubation with RNase. C-RNA concentration dur ing annealing:

$$
\text { - } \quad 200 \mu \mathrm{g} / \mathrm{ml}
$$

Assay: $\mathrm{P}^{32}$-C-RNA is denatured by heating to $100^{\circ} \mathrm{C}$ for 10 minutes in $0.01 \mathrm{M}$ Tris, $\mathrm{pH} 7$, cooled rapidly in ice and $\mathrm{NaCl}$ is added $0.1 \mathrm{M}$. The sample is then placed in a $55.0^{\circ} \mathrm{C}$ bath. Samples are removed periodically and assayed (method as Figure 4).

\section{COMMENTS}

The experiments described here provide several independent types of evidence that C-RNA may assume a highly ordered secondary structure in aqueous solution. The properties of C-RNA in this conformation are very similar to those of DNA, in that secondary structure transitions occur (Figure 1) which can only be reversed under special circumstances and involve intermolecular interactions (Figures 4,6). This is the first ribopolynucleotide of complex sequence that has been found to possess these properties. In view of the complementarity of T2-C-RNA with its template DNA, it seems overwhelmingly probable that this highly ordered conformation is, in fact, a DNA-like double helix. X-ray diffraction analysis will be needed to make this point absolutely certain. Evidently the ordered conformation of T2-C-RNA is an accident of the preparative method; the RNA is synthesized in a disordered conformation and ordering occurs imperfectly during the isolation. Deliberately designed annealing procedures yield a greater de- 
gree of ordering (cf. Figures 6 and 4).

The self-complementarity of C-RNA has one other significance. Our first experiments on the formation of DNA-C-RNA complexes had led us to believe that both strands of bacteriophage T2 DNA served as templates for C-RNA synthesis. The results reported here provide convincing supportive evidence, and indeed, Chamberlin and Berg have corroborated this point. ${ }^{4 *}$ In fact, the present experiments permit one to be more specific. Not only do both DNA strands serve as template for the RNA polymerase in vitro, but they must do so at complementary polynucleotide sequences in order to yield C-RNA chains that are themselves complementary with each other. It is most probable that these complementary DNA polynucleotide sequences are situated at corresponding locations on the two chains.

It is pertinent to summarize, at this point, the chemical and structural information on primer - product relationships in the reaction catalyzed by RNA polymerase. This is done in the reaction scheme of Figure 7, which incorporates the previously known properties of the RNA polymerase-catalyzed reaction and the results presented in this paper: 1) the requirement for four

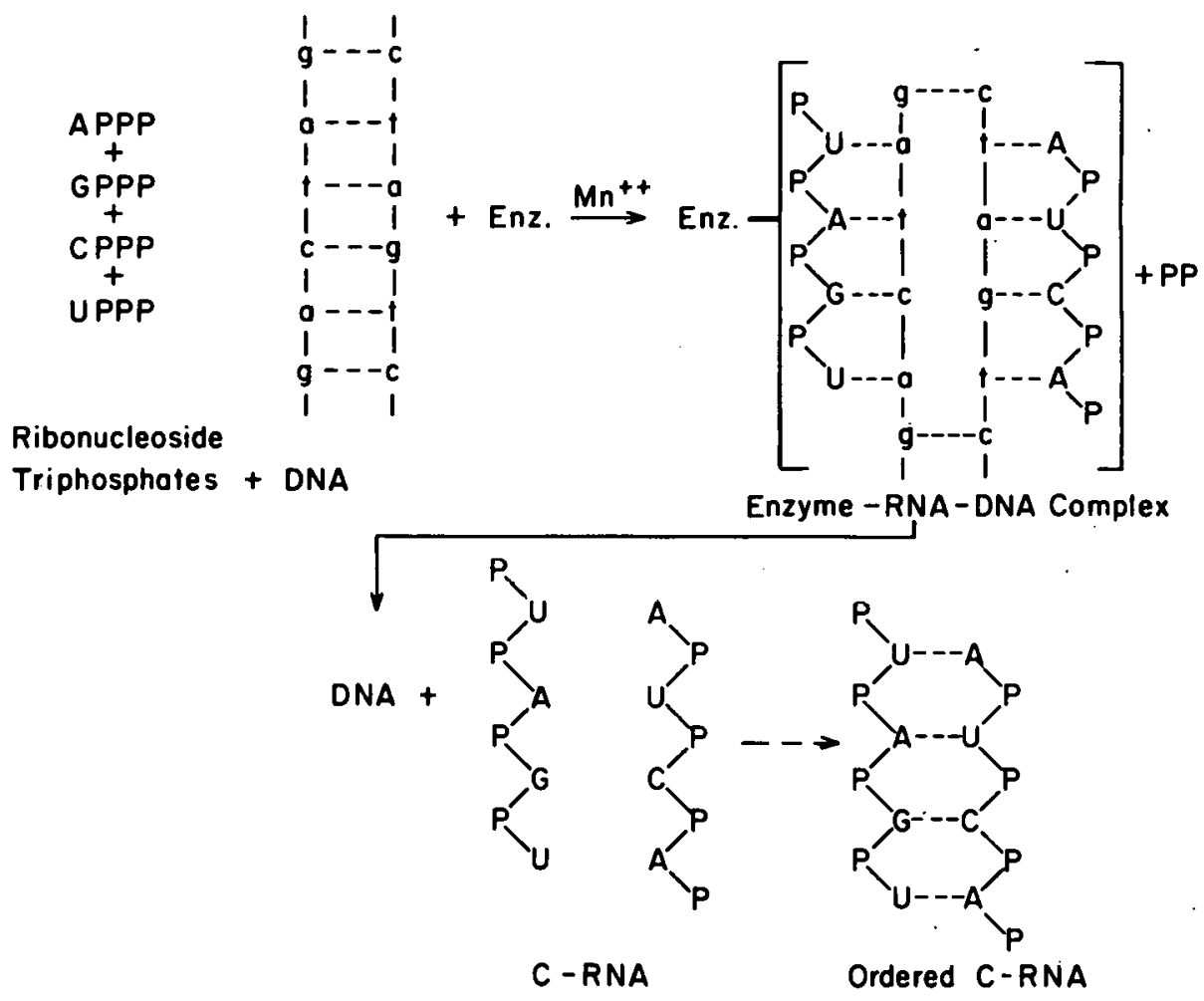

Figure 7. Synthesis of Complementary RNA. RNA nucleosides are denoted by capital letters, DNA nucleotides by lower case letters.

\footnotetext{
*Recently, Nakamoto and Weiss 15 have shown that the enzyme preparations used for the DNA-primed synthesis of C-RNA also catalyze an RNA-primed RNA polymerization. It is therefore possible that part of the RNA isolated for these experiments is made on a C-RNA rather than a DNA template. However, the relative rates of these two processes are such that under our synthetic conditions not more than 5 per cent of the C-RNA could have been made by the RNAprimed pathway. The self-complementarity of at least 85 per cent of T2-C-RNA (Figure 6), must therefore be a property of the DNA-primed RNA synthesis.
} 
nucleoside triphosphates, a DNA primer and divalent metal ions; 2) the correspondence of primer and product nucleotide composition and nearest neighbor sequence; 3 ) the relative ease with which DNA primer and C-RNA may be separated from each other; 4) the recovery of native DNA from the reaction mixture; and 5) the self-complementarity of synthesized C-RNA and its ability to assume a highly ordered conformation. The representation of the enzyme - template - product complex, on the other hand, is purely speculative. For example, it is not established (and not probable) that RNA chains may be assembled simultaneously from both strands of a single DNA molecule; they are shown in this way merely to represent the self complementarity of C-RNA.

The authors are grateful to T. Nakamoto for most helpful discussions and for preparations of RNA polymerase and RNA.

\section{LITERATURE CITED}

1. Weiss, S. B. Proc. Nat. Acad. Sci., 46:1020, 1960.

2. Stevens., A. J. Biol. Chem., 236:PC 43, 1961.

3. Furth, J. J., J. Hurwitz, and M. Goldman. Biochem. Biophys. Res. Comm., 4:362, 1961.

4. Chamberlin, M., and P. Berg. Proc. Nat. Acad. Sci., 48: 81, 1962.

5. Weiss, S. B., and T. Nakamoto. Proc. Nat. Acad. Sci., 47:694, 1961.

6. Weiss, S. B., and T. Nakamoto. Proc. Nat. Acad. Sci., 47:1400, 1961.

7. Geiduschek, E. P., T. Nakamoto, and S. B. Weiss. Proc. Nat. Acad. Sci., 47:1405, 1961.

8. Steiner, R. F., and R. F. Beers. Polynucleotides, Amsterdam: Elsevier Publishing Company, 1961.

9. Gierer, A., and G. Schramm. Z. Naturforschung, 11 B:138, 1956.

10. Haselkorn, R., and P. Doty. J. Biol. Chem., 236:2738, 1961.

11. Geiduschek, E. P. J. Mol. Biol., in press, 1962.

12. Hall, B. D., and S. Spiegelman. Proc. Nat. Acad. Sci., 47:137, 1961.

13. Marmur, J., and D. Lane. Proc. Nat. Acad. Sci., 46:451, 1960.

14. Doty, P., J. Marmur, J. Eigner, and C. Schildkraut. Proc. Nat. Acad. Sci., 46:461, 1960.

15. Nakamoto, T., and S. B. Weiss. Proc. Nat. Acad. Sci., 48:880, 1962. 


\section{STEROID PYROGEN STUDIES IN LABORATORY AND DOMESTIC ANIMALS ${ }^{*}$}

By

R. H. Palmer, B. Ratkovits, and A. Kappas

Recent studies from these laboratories have shown that a number of steroid metabolites derived from endogenous adrenocortical and gonadal hormones have consistent and powerful fever-producing action in human beings. ${ }^{1-4}$ This paper is a report of studies on the injection. of these pyrogenic steroids in various experimental animals. This investigation was prompted by the desirability of finding a species of experimental animal susceptible to fever induced by pyrogenic steroids so that studies on the physiologic characteristics and pathogenesis of this form of fever would be facilitated.

The results of this study indicate that several steroid metabolites shown to be pyrogenic in man consistently fail to induce significant temperature elevation in a wide variety of laboratory and domestic animals despite their administration by intramuscular, intravenous or intrathecal injection in large doses. Under comparable experimental conditions, fever induced by bacterial endotoxin could be easily elicited in appropriate animals.

\section{EXPERIMENTAL PROCEDURE}

Steroids used in this study were synthetically prepared and repeatedly purified until their physical constants were equal to the best samples reported. For intramuscular injection, steroids were dissolved in small amounts of propylene glycol or sesame oil: benzyl alcohol vehicle. ${ }^{2,4}$ For intravenous injection, steroids were dissolved in small amounts of 95 per cent ethanol. ${ }^{5}$ Rigid precautions were taken to exclude pyrogens as described previously. ${ }^{4}$ Species of animals used in this study were as follows: monkey (M. rhesus), rat (Holtzman, Gunn), rabbit (Swift Snuffle-Free) and mouse (CF No. 1, Carworth); and unpedigreed dog, cat, guinea pig, sheep, steer, pig and burro. All animals were adult and both sexes were represented in each series of injections. Temperatures were measured by indwelling rectal thermistor probes connected to a continuously recording, internally standardized, electronic temperature-recording device. Control temperature observations were made for 4-6 hours before each injection and temperatures were recorded continuously for 18-24 hours after injections, in all animals except for the sheep, pigs, burros and steers. Rectal temperatures in these animals were recorded four times daily for 1 week preceding steroid injection and every 3 hours for 2 days after each injection.

Intrathecal injections in a cat were made through a stainless-steel catheter permanently implanted into a lateral cerebral ventricle. Comparable injections in monkeys were made through polyethylene catheters implanted into the cisterna magna. Free flow of cerebrospinal fluid was demonstrated in each of the animals before steroid injections. To further insure the patency of these catheters, small amounts of bacterial endotoxin (Piromen) dissolved in the volumes of solvent vehicle (propylene glycol) used for steroid administration were injected into the catheters

\footnotetext{
*This paper appears in J. Appl. Physiol., 16:345, 1961.
} 
after each study, and prompt fever developed as expected. ${ }^{6}$ The number and types of animals, together with dose and route of steroid administration, used in this study are listed.

11-Ketopregnanolone (3a-hydroxypregnan-11, 20-dione):

Intramuscular injection, dose $1.0 \mathrm{mg} / \mathrm{kg}$; eight mice, nine rabbits, four cats, four dogs, four monkeys, nine rats, eight guinea pigs, three sheep, three steers, three pigs and three burros.

Intramuscular injection, dose $5.0 \mathrm{mg} / \mathrm{kg}$; five monkeys, seven guinea pigs, four cats, six rats, six rabbits, thirteen mice and four dogs.

Intravenous injection, dose $1.0 \mathrm{mg} / \mathrm{kg}$; four monkeys, three rabbits, four dogs and five cats. Intrathecal injection, dose $1.0 \mathrm{mg} / \mathrm{kg}$; one cat and two monkeys.

Pregnanolone (3a-hydrnxypregnan-2.0-rone): burros.

Intramuscular injection, dose $1.0 \mathrm{mg} / \mathrm{kg}$; three sheep, three steers, three pigs and three

Intramuscular injection, dose $5.0 \mathrm{mg} / \mathrm{kg}$; six cats, six rabbits, four dogs, four monkeys and six rats.

Intravenous injection, dose $1.0 \mathrm{mg} / \mathrm{kg}$; three rabbits, one heterozygous Gunn rat and one homozygous Gunn rat.

Intrathecal injection, dose $1.0 \mathrm{mg} / \mathrm{kg}$; one monkey and one cat.

Etiocholanolone (3a-hydroxyetiocholan-17-one):

Intramuscular injection, dose $1.0 \mathrm{mg} / \mathrm{kg}$; one monkey, one heterozygous Gunn rat and two homozygous Gunn rats.

Intramuscular injection, dose $5.0 \mathrm{mg} / \mathrm{kg}$; six rabbits, six cats, four dogs, six monkeys and seven rabbits.

Intrathecal injection, dose $1.0 \mathrm{mg} / \mathrm{kg}$; one monkey.

Androsterone (3a-hydroxyandrostan-17-one):

Intramuscular administration, dose $5.0 \mathrm{mg} / \mathrm{kg}$; six cats, six rats, six rabbits, two dogs, four monkeys, one heterozygous Gunn rat and one homozygous Gunn rat.

3

RESULTS

There were no consistent or significant temperature elevations produced by intramuscular, intravenous or intrathecal injections of these four steroid metabolites in the species of animals indicated. Consistent hypothermic responses to intramuscular injections of steroids in sesame oil in the mice were shown to be due to vehicle injection alone. Propylene glycol vehicle injec-tion did not produce either hypothermia or hyperthermia.

In order to demonstrate that the laboratory environment did not inhibit fever production in dogs, cats, rabbits and monkeys, two animals of each of these species received intravenous injections of small amounts of bacterial pyrogen (Piromen) and all responded with the typical endotoxin fever. 7,8

\section{DISCUSSION}

The adrenocortical and gonadal hormone metabolites, etiocholanolone, pregnanolone and 11-ketopregnanolone, have been shown to provoke consistent and intense pyrogenic reactions when injected into human subjects in small doses. ${ }^{1-4,9}$ The present study indicates, however, that these hormonal metabolites administered in large doses and via several routes of injection do not provoke significant temperature elevation in a variety of experimental animals. The phys iologic basis for this apparent high degree of species specificity of fever induced by steroid metabolites remains speculative, and it is probable that an exact explanation will require more definitive knowledge of the mechanism by which these steroids produce fever in man. However, the results of the present study merit brief discussion with respect to several factors having 
possible bearing on the mechanism of the species specificity of steroid pyrogen fever. First, absence of pyrogenic responses to intrathecal injection of large doses of etiocholanolone, pregnanolone and 11-ketopregnanolone in the monkeys and cats is especially significant despite the small number of experiments, since bacterial endotoxins administered by this route are intensely pyrogenic in doses several thousandfold smaller than those required to provoke fever by intravenous injection. ${ }^{6}$ More extensive studies by Petersdorf (personal communication) on intrathecal injection of etiocholanolone confirm the absence of febrile responses to steroid pyrogens administered by this route. Intrathecal injection of these compounds would, moreover, appear to minimize other factors which could potentially limit pyrogenic activity of these compounds in animals, such as inadequate absorption from injection sites, rapid conjugation and excretion or enzymatic inactivation. Second, the failure of these steroids to provoke significant temperature elevation in the limited experiments on the Gunn strain of rats is also of interest. These animals are known to have an hereditary deficiency in glucuronyl transferase activity resulting in defective bilirubin excretion. ${ }^{10}$ If this defect extends to steroid glucuronide formation as well, these animals in particular might have been expected to respond to the pyrogenic activity of these metabolites, and their failure to do so probably indicates that the apparent species specificity of steroid fever is not a consequence of extremely rapid inactivation of these metabolites in animals by the processes of conjugation and excretion. Finally, androsterone was injected into some animals during this study on the possibility that certain species, in contrast to man, might have developed thermoregulatory mechanisms responsive only to $5 a-\mathrm{H}$ steroids. The lack of pyrogenicity of this compound in the animals into which it was injected, however, makes this possibility unlikely.

Thus, the present study indicates that there is a high degree of species specificity to the phenomenon of fever induced by steroid metabolites. Although the physiologic basis for this specificity is not elucidated by this investigation it seems likely that in the animals studied it is real rather than artifactual. These observations thus provide further examples of the important species differences that may characterize the chemical nature of hormonal secretions, ${ }^{11}$ their metabolism 11,12 and their physiological manifestations. ${ }^{13-17}$ 'The possible significance of this species specificity to experimental and clinical investigations on the pathogenesis of fever has already been noted, ${ }^{4,9}$ and the probable etiologic relationship of steroid pyrogen to certain forms of human fever has been demonstrated. ${ }^{18,19}$

We express our_deep appreciation to Dr. Elwood V. Jensen and Dr. Herbert I. Jacobson, Ben May Laboratory for Cancer Research, The University of Chicago and Dr. David K. Fukushima, Sloan-Kettering Institute for Cancer Research, New York City for generous gifts of steroids. We also express our thanks to the following for assistance in various phases of this study: Dr. Sidney Schulman, Department of Medicine (Neurology), Dr. John F. Mullan and Dr. Anthony J. Raimondi, Department of Surgery (Neurosurgery), Dr. Paul B. Glickman, Department of Medicine, and Dr. K. L. Chow, Department of Physiology, The University of Chicago, Dr. Jose Souto, The University of Tennessee, Atomic Energy Commission Agricultural Research Laboratory, Knoxville, Tennessee, and Dr. Irwin Arias, Albert Einstein College of Medicine, Yeshiva University, New York City. 


\section{LITERATURE CITED}

1. Kappas, A., L. Hellman, D. K. Fukushima, and T. F. Gallagher. J. Clin. Endocrinol. and Metabolism, 17:451, 1957.

2. Kappas, A., L. Hellman, D. K. Fukushima, and T. F. Gallagher. J. Clin. Endocrinol. and Metabolism, 18:1043, 1958.

3. Kappas, A., W. Soybel, D. K. Fukushima, and T. F. Gallagher. Trans. Assoc. Am. Physicians, 72:54, 1959.

4. Kappas, A., W. Soybel, P. Glickman, and D. K. Fukushima. A.M.A. Arch. Internal. Med., $105: 701,1960$.

5. Kappas, A., and B. Ratkovits. J. Clin. Endocrinol. and Metabolism, 20:898, 1960.

6. Bennett, I. L., R. G. Petersdorf, and W. R. Keene. Trans. Assoc. Am. Physicians, 70:64, 1957.

7. Bennett, I. L., and P. B. Beeson. Medicine, 29:365, 1950.

8. Bennett, I. L., and L. E. Cluff. Pharmacol. Revs., 9:427, 1957.

9. Kappas, A., P. B. Glickman, and R. H. Palmer. Trans. Assoc. Am. Physicians, 73:176, 1960.

10. Arias, I. M. N. Y. State J. Med., 59:3759, 1959.

11. Bush, I. E. J. Endocrinol., 9:95, 1953.

12. Barry, M. C., M. L. Eidinoff, K. Dobriner, and T. F. Gallagher. Endocrinology, 50:587, 1952 .

13. Gallagher, T. F., L. Hellman, H. L. Bradlow, B. Zumoff, and D. K. Fukushima. Ann. New York Acad. Sc., 86:605, 1960.

14. Weisenfeld, S., and M. G. Goldner. J. Clin. Endocrinol. and Metabolism, 20:700, 1960.

15. Hecht-Lucari, G., and F. Lucisano. Proc. 1st Intern. Congr. Endocrinol., Copenhagen, 909, 1960.

16. Money, W. L., S. Kumacka, and R. W. Rawson. Ann. N. Y. Acad. Sci., 86:512, 1960.

17. Knobil, E., and R. O. Greep. Recent Progr. in Hormone Research, 15:1, 1959.

18. Bondy, P. K., G. L. Cohn, W. Herrmann, and K. R. Crispell. Yale J. Biol. and Med., 30: $395,1958$.

19. Bondy, P. K., G. L. Cohn, and C. Catiglione. Trans. Assoc. Am. Physicians, 73:186, 1960. 


\title{
PYROGENIC_AND_INFLAMMATORY_PROPERTIES OF CERTAIN BILE ACIDS IN MAN ${ }^{*}$
}

By

\author{
R. H. Palmer, P. B. Glickman, and A. Kappas
}

This is a report on the pyrogenic and inflammatory properties of certain bile acids in man. The study was prompted by the structural similarity between these acidic steroids and the pyrogenic neutral steroids described previously. ${ }^{1-6}$ In addition, it seemed important to establish whether the large quantities of steroid acids formed during the metabolism of cholesterol could serve as a source of endogenous compounds having fever-producing action in man.

\section{METHODS AND RESULTS}

Nineteen bile acids and derivatives were examined for fever-producing activity following their intramuscular administration to adult volunteer hospital patients. Lithocholic acid was repeatedly recrystallized to insure purity. The glycine, taurine and acetyl derivatives of lithocholic acid were synthesized and purified in these laboratories: the other compounds were obtained commercially and used without additional purification. All bile acids were dissolved in propylene glycol, in concentrations of 12.5 and $25.0 \mathrm{mg} / \mathrm{ml}$, and because of their acidity these solutions were neutralized with dilute base. The general details of the study, including precautions taken to exclude bacterial pyrogen contamination, were similar to those described in a previous report. ${ }^{2}$ The compounds examined, together with the incidence of pyrogenic responses following their injection are listed below:

1. Lithocholic acid ( $3 a$-hydroxycholanic acid). Nineteen subjects received 22 IM injections of 6-50 mg each. Pyrogenic responses at different doses were as follows: $6 \mathrm{mg}-5$ out of $5 ; 12$ $\mathrm{mg}-6$ out of $7 ; 25 \mathrm{mg}-7$ out of $8 ; 50 \mathrm{mg}-1$ out of 2 . In general, pyrogenic reactions were similar to those previously described with neutral steroid pyrogens and the responses of 3 subjects to injection of $6 \mathrm{mg}$ of this bile acid are shown in Figure 1. At this small dose, lithocholic acid appeared to be more intensely pyrogenic than either etiocholanolone or pregnanolone. ${ }^{3,5}$

Local inflammatory reactions were regularly observed following injection of this steroid. The onset of inflammation, characterized by the usual physical signs, was variable, ranging from 6 - 30 hours after injection. The inflammation usually increased for $2-3$ days and then gradually regressed, with an indolent course sometimes lasting $2-4$ weeks. Histologically, biopsies of injection sites showed edema and necrosis of tissue, with a marked polymorphonuclear infiltrate. Further details will form the basis of a subsequent report. A photomicrograph of a biopsy taken 4 days after injection is shown in Figure 2. It is of interest that the period of most intense inflammation usually occurred well after the fever had subsided.

Constitutional symptoms such as headache, malaise, nausea, anorexia, etc. were intense, and patients frequently complained of an unusually strong sense of fatigue. Myalgias and arthral-

\footnotetext{
${ }^{*}$ This paper appears in J. Clin. Invest., 41:1573 ${ }_{1062)}^{\text {(aug. }}$

${ }^{\dagger}$ Study supported in part by the Joseph and Helen Regenstein Foundation.
} 


\section{BILE ACID FEVER IN MAN}

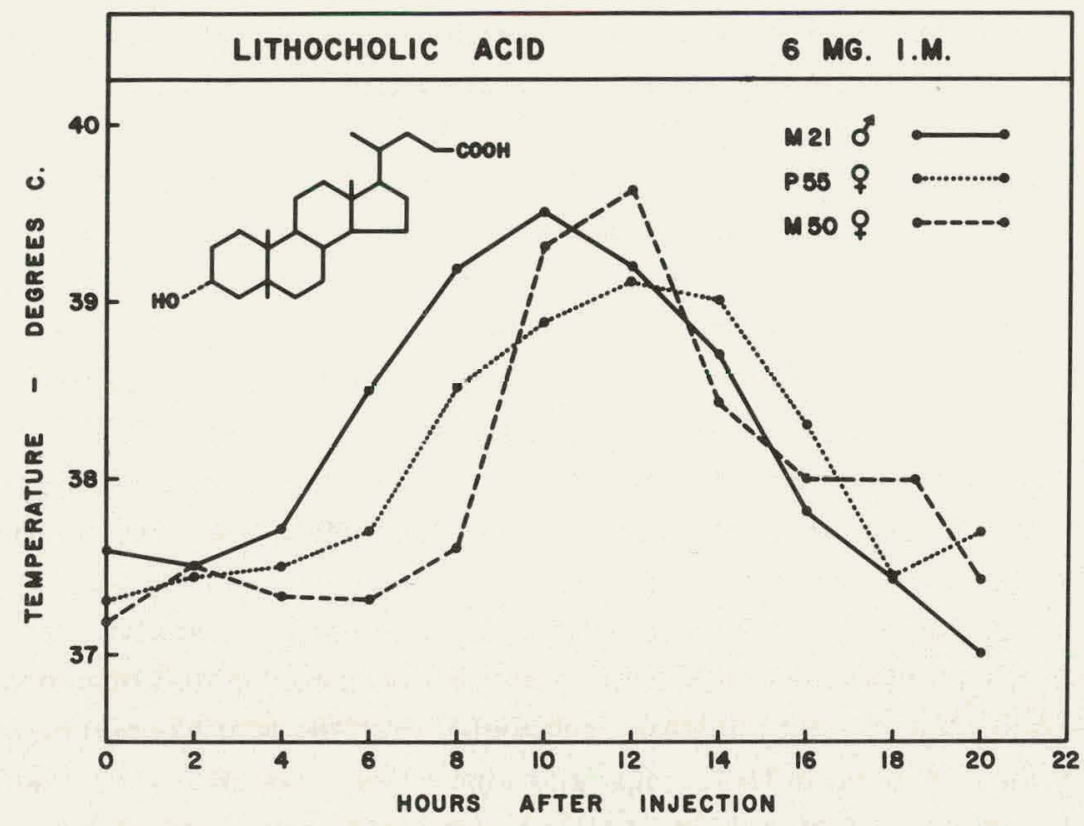

Figure 1. Febrile responses of three subjects to the intramuscular injection of $6 \mathrm{mg}$ of lithocholic acid.

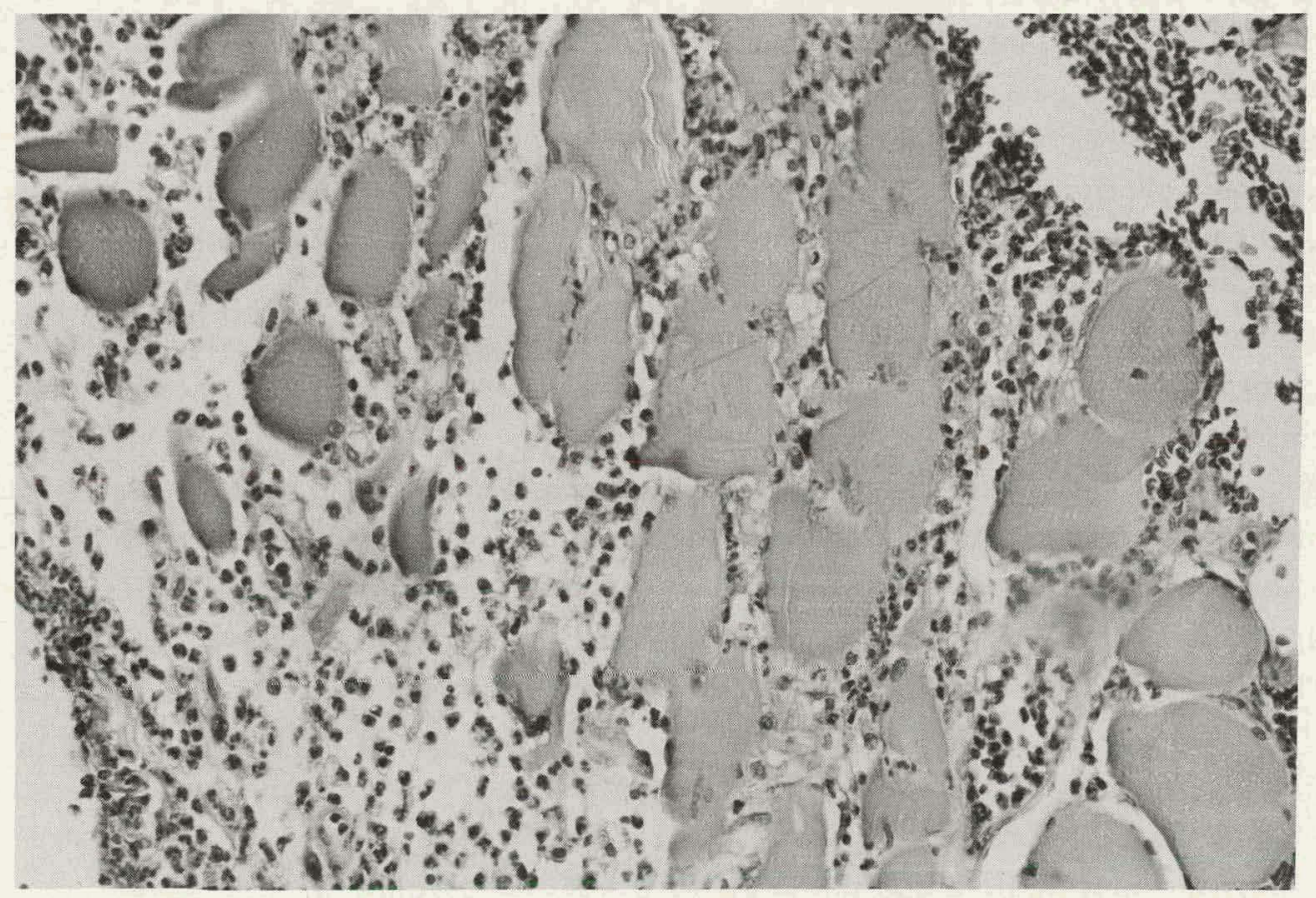

Figure 2. Acute inflammatory reaction following the intramuscular injection of lithocholic acid. $252 \mathrm{X}$ 
gias were less frequent than observed following neutral steroid pyrogen injections.

2. 3-acetyllithocholic acid. This compound was administered to 4 subjects in single doses of $25 \mathrm{mg}$ each. All developed intense pyrogenic reactions, although in one the onset of fever was delayed until the day following injection. Inflammatory reactions and constitutional symptoms were comparable to those produced by lithocholic acid.

3. 24-methyllithocholic acid. One subject received $25 \mathrm{mg}$ and two received $12 \mathrm{mg}$ each. All developed intense pyrogenic responses, the larger dose causing a prolonged fever lasting 5 days. Inflammatory reactions and constitutional symptoms were correspondingly severe. Because of the intensity of these responses, no further testing was done.

4. Glycolithocholic acid. Five subjects received $12 \mathrm{mg}$ and four received $25 \mathrm{mg}$ each. In addition, two other subjects received $21 \mathrm{mg}$ each, the steroid solution having been sterilized by Seitz filtration rather than autoclaving. All subjects, except one, developed pyrogenic and inflammatory reactions similar to those obtained with unconjugated lithocholic acid. The single subject who did not develop a fever after receiving an injection of $12 \mathrm{mg}$, did develop a $2 \mathrm{~cm} \mathrm{x}$ $2 \mathrm{~cm}$ area of inflammation at the site of injection. Chromatographic analysis of the glycolithocholic acid used in these injections showed it to be free of unconjugated precursor.

5. Taurolithocholic acid. Six subjects received $12 \mathrm{mg}$ and four received $25 \mathrm{mg}$ each. The maximum temperature reached in the group receiving $12 \mathrm{mg}$ was $38.3^{\circ} \mathrm{C}$ (one subject) and in the group receiving $25 \mathrm{mg}, 38^{\circ} \mathrm{C}$ (one subject). All other patients remained afebrile despite the presence in all of intense local inflammatory reactions which were frequently as severe as those produced by glycolithocholic or lithocholic acids. Because of the severity of these reactions, no attempt was made to elicit fever with doses greater than $25 \mathrm{mg}$. Figure 3 shows a biopsy of one reaction to an injection of $25 \mathrm{mg}$ together with the corresponding temperature record.

In addition to consistently developing intense inflammatory reactions, unaccompanied by fever, most subjects receiving taurolithocholic acid complained of marked constitutional symptoms, especially anorexia and a strong sense of fatigue.

6. Hyodeoxycholic acid ( $3 a, 6 a$ dihydroxycholanic acid). Five subjects received $100 \mathrm{mg}$ each. One developed a marked febrile response, two developed low grade but significant fevers, and two subjects had no febrile responses.

7. Ursodeoxycholic acid ( $3 a, 7 \beta$ dihydroxycholanic acid). This compound was tested in nine subjects in amounts of $100 \mathrm{mg}$ each. One subject developed a moderately intense fever, three responded with small but significant temperature rises, and five showed no temperature elevations.

Despite several pyrogenic reactions among the subjects receiving these last two compounds, no inflammatory reactions were noted grossly and none of the subjects complained of local tenderness. However, three subjects (two of whom remained afebrile) complained of some of the previously described constitutional symptoms following injection of ursodeoxycholic acid.

8. The following twelve compounds were non-pyrogenic when tested in at least six subjects in doses of $100 \mathrm{mg}$ each:

7-ketolithocholic acid ( $3 a$ hydroxy 7 ketocholanic acid)

3,6 diketocholanic acid

chenodeoxycholic acid ( $3 a, 7 a$ dihydroxycholanic acid)

deoxycholic acid $(3 a, 12 a$ dihydroxycholanic acid)

apocholic acid ( $3 a, 12 a$ dihydroxy 8-14 cholenic acid)

diketolithocholic ( $3 a$ hydroxy 7, 12 diketocholanic acid) 
dehydrocholic acid $(3,7,12$ triketocholanic acid)

cholic acid ( $3 \alpha, 7 a, 12 \alpha$ trihydroxycholanic acid)

glycocholic acid

taurocholic acid

lithobilianic acid

Among these patients there were scattered instances of mild temperature elevations (or absence of normal nocturnal temperature depressions) but these did not form a consistent pattern and were not considered significant. In addition, no inflammatory reactions or constitutional symptoms developed following injection of these steroids.

\section{DISSOCIATION OF FEVER AND INFLAMMATION}

\section{TAUROLITHOCHOLIC ACID 25 MG. I.M.}

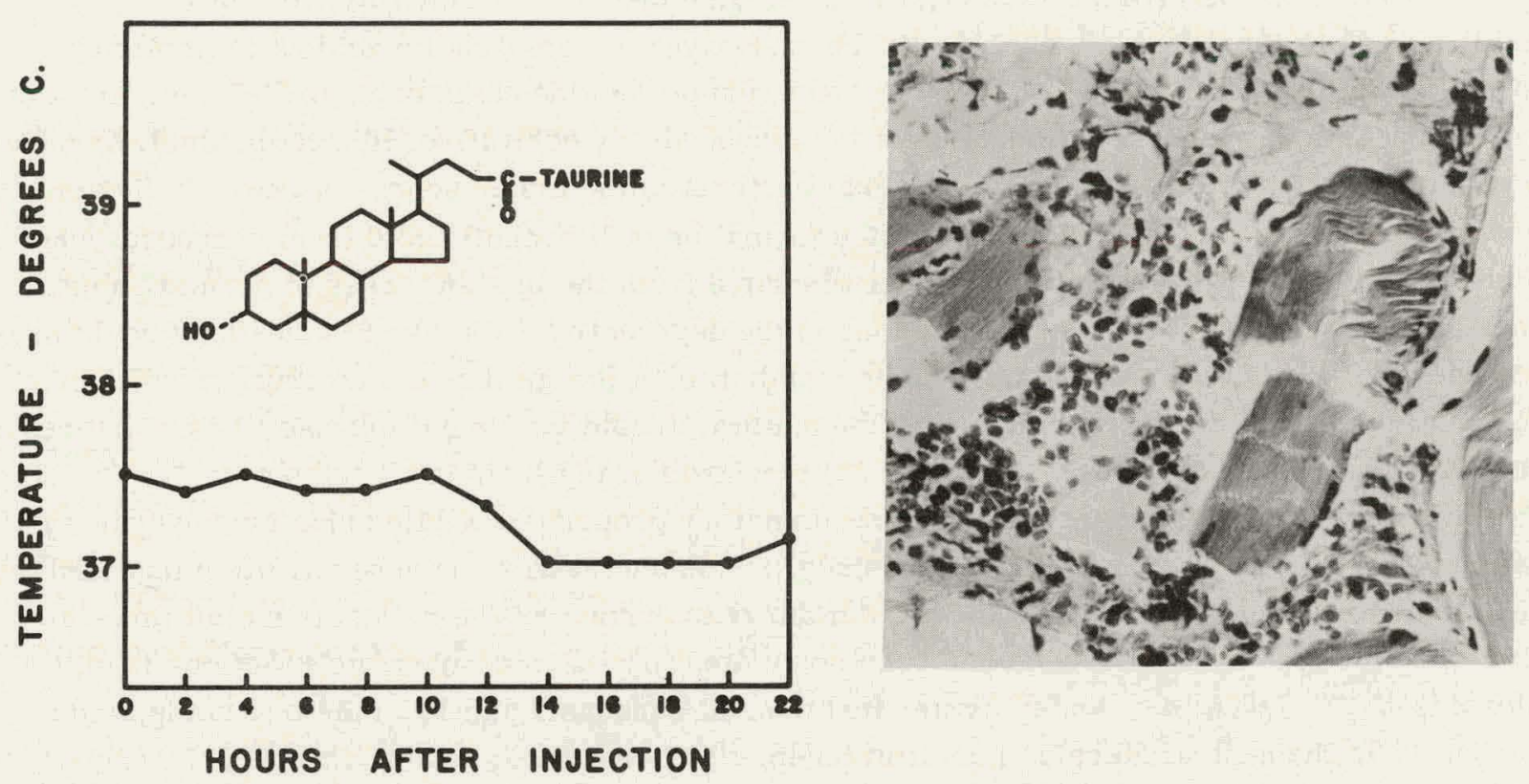

Figure 3. Acute inflammation reaction following the intramuscular injection of taurolithocholic acid in the absence of any febrile response. $315 \mathrm{X}$

\section{DISCUSSION}

The pyrogenic neutral steroid hormone metabolites described previously belong to the $5 \beta-\mathrm{H}$ series of compounds, in which the hydrogen atom projects in front of the plane of the nucleus, and the A:B ring junction is angular (cis). This molecular configuration also characterizes the bile acids, which represent the principal steroid end products of cholesterol metabolism. The large amounts of these steroid acids formed daily from the breakdown of cholesterol thus represent a large potential source of endogenous fever-producing agents in man.

The present investigations demonstrate that several of these biliary compounds do indeed have powerful thermogenic and inflammatory properties when administered intramuscularly to humans. Thus they extend the number of known steroid pyrogens to include non-hormonal deriv- 
atives, and stimulate interest in the possible participation of these toxic biliary substances in clinical disorders in a manner previously demonstrated for the neutral steroid pyrogen etiocholanolone. ${ }^{7,8}$ The activity of lithocholic acid and its conjugates demonstrated in this study makes these monohydroxy compounds of special interest in this regard, although these substances may prove to be only the most potent of a series of pharmacologically active related steroids.

The origin of lithocholic acid and its derivatives, and their concentrations in tissues, fluids and intestinal contents are not well known. However, approximately $1000 \mathrm{mg}$ of cholesterol are degraded to bile acids daily. ${ }^{9,10}$ During this process, hydroxylation of the nucleus occurs, first at carbon 7 and then at carbon 12, resulting in the two principal bile acids in man, chenodeoxycholic and cholic acids. Lithocholic acid could be formed either by failure of $\mathrm{C}-7$ hydroxylation initially or through subsequent bacterial dehydroxylation in the intestine. In the formation of bile acids, oxidation of the terminal side chain seems to prevent further nuclear hydroxylation, and the timing of this process is thought to determine the ratio of dihydroxy to trihydroxy bile acids. Presumably thyroxin increases the chenodeoxycholic acid/cholic acid ratio in bile by stimulating this oxidation. ${ }^{10,11}$ Similarly, oxidation of the side chain prior to C-7 hydroxylation could result in an increased production of the monohydroxy derivative, lithocholic acid. Carbon 7 dehydroxylation of cholic acid by intestinal bacteria is the major source of deoxycholic acid, ${ }^{10}$ and an analogous process could result in the formation of lithocholic acid from chenodeoxycholic acid. In any event, lithocholic acid has been isolated from the bile and feces of normal subjects in significant amounts, ${ }^{12-15}$ and alterations in the degradative pathway of cholesterol could lead to excessive production of this highly toxic metabolite. Although there is no present evidence of the participation of this pyrogenic and inflammatory steroid in clinical disease, it is of interest that this compound can produce experimental cirrhosis of the liver in other species. ${ }^{16-18}$

Suppression of the thermogenic and inflammatory properties of bile acids by polyhydroxylation of the nucleus, as observed in this study, is consistent with the generalization that additional chemical functions which project from the rear surface of the molecule inhibit these activities. This type of interference has been postulated for enzyme-substrate reactions in other steroids. ${ }^{19-22}$ Hence, $\alpha$-oriented oxygen functions at carbons 7 and 12 in the bile acids, and at carbon 17 in the neutral steroids inhibit pyrogenicity. In contrast, $\beta$-orientation of the carbon 11 oxygen substituent in neutral steroids has little effect on fever-producing activity. ${ }^{3}$ The two dihydroxy bile acids found to have weak and irregular thermogenic action (ursodeoxycholic and hyodeoxycholic acids) have additional hydroxyl groups in the $7 \beta$ and $6 a$ positions respectively, and although the equatorial orientation of both hydroxyls may account for incomplete suppression of fever-producing action, individual differences in response to injected steroids, noted previously, ${ }^{5}$ may be of some importance in determining the consistency of the pyrogenic reaction to these compounds.

The powerful thermogenic and inflammatory properties of chemical and physiologic conjugates of lithocholic acid are of some interest and potential significance. It has generally been assumed that in vivo conjugation of steroids represents in part an inactivating process, and previous studies with neutral steroid pyrogens demonstrated that chemical esters such as etiocholanolone and pregnanolone acetate, as well as physiologic conjugates such as the sulfate and glucosiduronate derivatives of etiocholanolone, were devoid of fever-producing activity. ${ }^{23,24}$ Bile acid pyrogens appear to differ strikingly from the neutral steroids in this regard. Esteri- 
fication of lithocholic acid at both terminal positions of the steroid nucleus, exemplified by 3acetyllithocholic and 24-methyllithocholic acids, did not result in suppression of pyrogenicity. Indeed the latter compound produced both prolonged and intense fever. Moreover, both physiological conjugates of this bile acid retained powerful thermogenic and/or inflammatory activity. Thus it would appear that conjugation processes do not necessarily terminate the biological activity of steroid pyrogens, a consideration which must be taken into account when evaluating the possible role of these steroids in the pathogenesis of certain clinical disorders. ${ }^{28,6}$

It is also apparent that the nature of the conjugating substance may determine the type of pharmacologic action manifested by certain steroids, since in the present study, dissociation of the inflammatory from the pyrogenic action of lithocholic acid was determined by the type of conjugating amino acid. Thus alterations in the ratio of taurine/glycine conjugates, which are known to occur with changes in age, diet, or in liver disease ${ }^{25-27}$ may alter the possible biological effects of endogenously produced lithocholic acid.

The ability of taurolithocholic acid to produce intense local inflammatory reactions as well as constitutional symptoms, without significant fever, is of special importance and implies that these effects may be independent pharmacologic properties of bile acids. Thus the production of constitutional symptoms may not be directly the result of fever, nor does non-specific inflammation per se explain the mechanism of steroid-induced fever in man.

\section{SUMMARY}

Nineteen free and conjugated bile acids were examined for pyrogenic properties. The results of this study indicate:

1. The endogenous biliary steroid lithocholic acid has significant inflammatory and pyrogenic action in man. It is possible that aberrations in the degradation of cholesterol to bile acids or enteric microbial dehydroxylation of these compounds might result in excessive production of this extremely active steroid pyrogen which, by inference, could then participate in febrile and inflammatory clinical disorders.

2. The potent pharmacological properties of chemical and physiological esters of lithocholic acid demonstrate that in vivo conjugation processes do not necessarily terminate the biological activity of steroids.

3. Production of intense inflammation without significant fever by taurine-conjugated lithocholic acid strongly suggests that non-specific inflammation per se does not explain the mechanism of steroid fever in man.

\section{LITERATURE CITED}

1. Kappas, A., L. Hellman, D. K. Fukushima, and T. F. Gallagher. J. clin. Endocr., 16:948, 1956.

2. Kappas, A., L. Hellman, D. K. Fukushima, and T. F. Gallagher. J. clin. Endocr., 17:451, 1957.

3. Kappas, A., W. Soybel, D. K. Fukushima, and T. F. Gallagher. Trans. Assoc. Amer. Phycns., 72:54, 1959.

4. Kappas, A., P. B. Glickman, and R. H. Palmer. Trans. Assoc. Amer. Phycns., 73:176, 1960.

5. Kappas, A., W. Soybel, P. Glickman, and D. K. Fukushima. Arch. intern. Med., 105:701, 1960. 
6. Kappas, A., R. H. Palmer, and P. B. Glickman. Amer. J. Med., 31:167, 1961.

7. Bondy, P. K., G. L. Cohn, and C. Castiglione. Trans. Assoc. Amer. Phycns., 73:186, 1960.

8. Cohn, G. L., P. K. Bondy, and C. Castiglione. J. clin. Invest., 40:400, 1961.

9. Lindstedt, S. Acta physiol. scand., 40:1, 1957.

10. Bergstrom, S. In Hormones and Atherosclerosis, G. Pincus, ed., New York: Academic Press, Inc., 1959, p. 31 .

11. Erikssen, S. Proc. Soc. Exptl. Biol., 94:582, 1957.

12. Wootton, I. D. P., and H. S. Wiggins. Biochem. J., 55:292, 1953.

13. Isaakson, B. Acta Soc. Med. upsalien., 59:307, 1954.

14. Heftmann, E., E. Weiss, K. K. Miller, and E. Mosettig. Arch. Biochem., 84:324, 1959.

15. Rosenfeld, R. Personal communication.

16. Holsti, P. Acta path. microbiol. scand., Supp. 113, 1956.

17. Holsti, P. Nature, 186:250, 1960.

18. Stolk, A. Experientia (Basel), 16:507; 1960.

19. Figdor, S. K., M. J. Kodet, B. M. Bloom, E. J. Agnello, S. Y. P'an, and G. D. Laubach. J. Pharmacol. Exptl. Ther., 119:199, 1957.

20. Glenn, E. M., R. O. Stafford, S. C. Lyster, and B. J. Bowman. Endocrinology, 61:128, 1957.

21. Bush, I. E., and V. B. Mahesh. Biochem. J., 71:705, 1959.

22. Bush, I. E., and V. B. Mahesh. Biochem. J., 71:718, 1959.

23. Baulieu, E. E. Personal communication.

24. Palmer, R. H. Unpublished observations.

25. Encrantz, J., and J. Sjovall. Clin. chim. Acta, 4:793, 1959.

26. Sjovall, J. Proc. Soc. exptl. Biol., 100:676, 1959.

27. Ekdahl, P., and V. Stenram. Acta chir. scand., 115:189, 1958.

28. Palmer, R. H., P. B. Glickman, and A. Kappas. J. Clin. Invest., 40:1069, 1961. 


\section{PARATHYROID HORMONE AND WHOLE BODY OXIDATION_OE_GLUCOSE, PYRUVATE, AND CITRATE BY THE INTACT RAT \\ By \\ J. L. Spratt ${ }^{\dagger}$ and Gar Bo $\mathrm{Ho}^{\ddagger}$}

In 1956 Neuman et al. ${ }^{1}$ and in 1958 Neuman and Neuman ${ }^{2}$ postulated that parathyroid hormone inhibits the pentose shunt pathway of glucose metabolism as well as the oxidation of isocitric acid in the tricarboxylic acid cycle, and stated that both these inhibitory actions resulted from the destruction of the chromophoric group of triphosphopyridine nucleotide. Reasoning from this hypothesis, it might therefore be expected that citrate would accumulate in bone, and such an increase in the concentration of citrate in bone tissue under the influence of parathyroid hormone, has, in fact, been demonstrated. ${ }^{1,3}$ More recently, a report from Neuman's laboratory has advanced the hypothesis that parathyroid hormone effects an increase in glycolysis by augmenting the intracellular concentration of phosphate ions, thus resulting in an increased production of lactic and pyruvic acids. ${ }^{4}$ In this latter formulation, the emphasis has been shifted from the formation of a calcium-citrate complex to the solubilizing effect of metabolic acids. These formulations together with earlier reports of a transient hypoglycemia produced by parathyroid extract, ${ }^{5-8}$ prompted us to investigate the whole-body oxidation of glucose following the administration of parathyroid extract. In view of the interest in the effects of the parathyroid on citrate metabolism, citrate and pyruvate oxidation were also studied.

\section{METHODS}

Wistar albino littermate female rats weighing 65-85 g were starved overnight and 10 units of parathyroid extract (Parathyroid Injection, U.S.P., Lilly) was administered intravenously to 16 animals 30 minutes before injection of a radiotracer. Groups of 4 animals then received 2.0 $\mu \mathrm{c}$ glucose-1- $\mathrm{C}^{14}(2.8 \mu \mathrm{c} / \mathrm{mg}$, New England Nuclear Corporation, Boston, Massachusetts), 2.0 $\mu \mathrm{c}$ glucose-6- $\mathrm{C}^{14}(2.0 \mu \mathrm{c} / \mathrm{mg}$, New England Nuclear Corporation, Boston, Massachusetts), 0.3 $\mu \mathrm{c}$ sodium citrate-1,5- $\mathrm{C}^{14}(3.6 \mu \mathrm{c} / \mathrm{mg}$, New England Nuclear Corporation, Boston, Massachusetts), or $0.3 \mu \mathrm{c}$ sodium pyruvate-1- $\mathrm{C}^{14}(42.7 \mu \mathrm{c} / \mathrm{mg}$, Nuclear Chicago Corporation, Chicago, Illinois) intravenously. In addition, two groups of 4 animals received the parathyroid extract at either 10 minutes or 50 minutes before citrate-1,5-C $\mathrm{C}^{14}$. Groups of 4 animals injected intravenously with a volume of saline equivalent to that of the parathyroid extract were used as controls for each group studied.

Immediately following injection of the radioactive intermediate, the animal was placed in a sealed chamber/and the radioactive carbon dioxide contained in the expired air was continuously monitored and graphically recorded for 1 hour. The apparatus is described elsewhere. ${ }^{9}$

*This paper appears in Arch. int. Pharmacodyn., 1962.

$\dagger$ Present address: Department of Pharmacology, State University of Iowa, Iowa City, Iowa.

${ }^{\ddagger}$ Department of Pharmacology, University of Chicago. 


\section{RESULTS AND DISCUSSION}

As can be seen in Table 1, the production of $\mathrm{C}^{14} \mathrm{O}_{2}$ from glucose-1- $\mathrm{C}^{14}$ and glucose-6-C ${ }^{14}$, expressed as per cent of the injected dose cumulated during stated time intervals, is not significantly different in the control and parathyroid extract treated animal. Oxidation of pyruvate, a precursor of citrate, was quite similar in both groups, and there was no significant difference in the oxidation of citrate itself.

Table 1

CUMULATIVE PER CENT OF INJECTED DOSE. DATA EXPRESSED AS MEAN \pm STANDARD DEVIATION*

\begin{tabular}{|c|c|c|c|c|}
\hline \multirow{2}{*}{$\begin{array}{c}\text { Precursor } \\
\text { (injected } 30 \text { min. after } \\
\text { parathyroid extract) }\end{array}$} & \multirow{2}{*}{ Treatment } & \multicolumn{3}{|c|}{ Time after precursor injection } \\
\hline & & $10 \mathrm{~min}$. & $30 \mathrm{~min}$. & $50 \mathrm{~min}$. \\
\hline Glucose-1-C 14 & $\begin{array}{l}\text { Saline control } \\
\text { Parathyroid extract }\end{array}$ & $\begin{array}{r}0.81 \pm 0.23 \\
0.63 \pm 0.23 \\
0.3<\mathrm{p}<0.4\end{array}$ & $\begin{array}{r}5.28 \pm 1.52 \\
4.17 \pm 1.09 \\
0.2<\mathrm{p}<0.3\end{array}$ & $\begin{array}{r}10.45 \pm 2.62 \\
8.67 \pm 2.44 \\
0.3<\mathrm{p}<0.4\end{array}$ \\
\hline Glucose-6-C $C^{14}$ & $\begin{array}{l}\text { Saline control } \\
\text { Parathyroid extract }\end{array}$ & $\begin{array}{c}0.58 \pm 0.40 \\
0.51+0.13 \\
0.7<\mathrm{p}<0.8\end{array}$ & $\begin{array}{r}4.00 \pm 0.49 \\
4.10 \pm 1.40 \\
0.8<p<0.9\end{array}$ & $\begin{array}{r}8.61 \pm 0.89 \\
8.39 \pm 2.00 \\
0.8<p<0.9\end{array}$ \\
\hline Py ruvate $-1-\mathrm{C}^{14}$ & $\begin{array}{l}\text { Saline control } \\
\text { Parathyroid extract }\end{array}$ & $\begin{array}{l}11.63 \pm 2.33 \\
12.45 \pm 2.86 \\
0.6<\mathrm{p}<0.7\end{array}$ & $\begin{array}{l}28.94 \pm 6.73 \\
25.51 \pm 3.52 \\
0.4<p<0.5\end{array}$ & $\begin{array}{l}35.94 \pm 8.61 \\
30.68 \pm 3.17 \\
0.2<\mathrm{p}<0.3\end{array}$ \\
\hline Citrate-1,5-C $\mathrm{C}^{14}$ & $\begin{array}{l}\text { Saline control } \\
\text { Parathyroid extract }\end{array}$ & $\begin{array}{c}8.32 \pm 1.69 \\
8.09 \pm 1.12 \\
0.8<p<0.9\end{array}$ & $\begin{array}{l}23.42 \pm 3.94 \\
21.78 \pm 3.58 \\
0.5<p<0.6\end{array}$ & $\begin{array}{l}31.35 \pm 4.47 \\
30.16 \pm 4.77 \\
0.7<p<0.8\end{array}$ \\
\hline
\end{tabular}

* Standard deviation calculated as $\sqrt{\frac{\Sigma d^{2}}{n-1}} \cdot p$ values indicate control versus experimental values at time intervals indicated.

Animals injected with citrate-1,5-C $\mathrm{C}^{14}$ at 10 minutes and 50 minutes after parathyroid extract showed no significant differences in $\mathrm{C}^{14} \mathrm{O}_{2}$ excretion when compared with the animals injected with citrate at 30 minutes following parathyroid extract. These figures have not been included in the table.

Previous work on the hypoglycemic effect produced by the administration of parathyroid extract indicates that this is dependent on the functional integrity of the pancreatic islet tissue. ${ }^{5-7}$ The effect was stated to be transient and the data were often inadequate for statistical analysis. ${ }^{8}$ The animals used in the present study had no pancreatic disturbance, and might have been expected to show significant differences in $\mathrm{C}^{14} \mathrm{O}_{2}$ production if parathyroid extract caused changes in blood glucose levels: such changes in glucose oxidation were not observed.

The suggestion that parathyroid hormone influences the pathway of glucose metabolism ${ }^{1,2}$ and the rate of glycolysis ${ }^{4}$ is not reflected in our data. The experiments described here are concerned with whole-body oxidation of glucose, and therefore our data are not incompatible with 
either postulate, provided that the authors are restricting their arguments to hormone effects on specific target tissues, and that these specific tissue effects can be demonstrated. However, we see no reason a priori why parathyroid hormone should exert a specific effect on triphosphopyridine nucleotide in bone tissue, while having no influence on this coenzyme in other tissues.

It has been reported that 100 units $/ \mathrm{kg}$ of intravenous parathyroid extract causes a marked increase in systemic plasma citrate levels within an hour in the dog, while changes in plasma phosphate and calcium do not occur until much later. 3,10 This increase is not reflected in the whole-body oxidation of pyruvate and citrate in our experiments on rats receiving $133 \mathrm{units} / \mathrm{kg}$ of parathyroid extract, although the time intervals in our experiments were chosen with the special objective of observing this early citrate change.

\section{LITERATURE CITED}

1. Neuman, W. F., H. Firschein, P. S. Chen, Jr., B. J. Mulryan, and V. Distefano. J. Am. Chem. Soc., 78:3863, 1956.

2. Neuman, W. F., and M. W. Neuman. The Chemical Dynamics of Bone Mineral, Chicago, Illinois: University of Chicago Press, 1958.

3. Firschein, H. E., W. F. Neuman, G. R. Martin, and B. J. Mulryan. Rec. Prog. Horm. Research, 15:427, 1959 .

4. Terepka, A. R., C. M. Dowse, and W. F. Neuman. University of Rochester AEC Report \#UR-577, 1960.

5. Seelig, S. Z. ges. exptl. Med., 78:796, 1931.

6. Olmer, J., and J. E. Paillas. Presse med., 44:1418, 1936.

7. Olmer, J., J. Paillas, and B. Signasi. Compt. rend. Soc. de biol., 12 1:78, 1936.

8. Parhon, C. I., and H. Derevici. Compt. rend. Soc. de biol., 107:388, 1931.

9. Spratt, J. L., and G. V. LeRoy. Proc. Soc. Exptl., Biol. and Med., 107:106, 1961.

10. Firschein, H., G. Martin, B. J. Mulryan, B. Strates, and W. F. Neuman. J. Am. Chem. Soc., 80:1619, 1958. 


\section{PEPTIDE SYNTHESIS IN BONE MARROW: INSULIN AND}

THYROXINE EFFECTS*

By

T. F. Necheles ${ }^{\dagger}$

It has long been recognized that the normal activity of bone marrow is to some extent under the control of humoral agents, ${ }^{1-7}$ but whether these substances can directly stimulate synthetic events in this tissue has been an open question. The present experiments deal with the in vitro effects of insulin and thyroxine on the incorporation of amino acids into protein and on incorporation of various precursors into nucleic acids in isolated bone marrow slices.

\section{MATERIALS AND METHODS}

Male rabbits, 1700-2500 g, of a highly inbred local strain, fasted 24 hours, were sacrificed; the femurs were removed rapidly, and the cortex of the bone was opened with bone forceps. Marrow from the proximal end was removed with a narrow blade spatula, using utmost care not to disturb the architecture of the tissue (Bornstein and Sheath, personal communication). The cylinder of marrow was transferred to a 'Parafilm' (Fisher Scientific Company) sheet and transverse sections were made with a razor blade; 25-30 mg samples were transferred to $1 \times 1$ $\mathrm{cm}$ squares of 'Parafilm,' weighed, and placed in $20-\mathrm{ml}$ beakers containing $1.7 \mathrm{ml}$ ice cold Krebs-Henseleit bicarbonate buffer without glucose. ${ }^{8}$ After addition of hormone and radioactive precursor, the beakers were shaken at 60 cycles per minute for 1 hour at $37.5^{\circ} \mathrm{C}$ in a gas phase of 95 per cent $\mathrm{O}_{2}-5$ per cent $\mathrm{CO}_{2}$. Each incubation mixture was then quantitatively transferred to a graduated centrifuge tube and the reaction stopped by addition of 10 per cent trichloroacetic acid or by quick freezing in a $-70^{\circ}$ acetone-dry ice bath. Each experiment was made with marrow from a single rabbit; triplicate, quadruplicate, or sextuplicate samples were tested, and analyzed separately, for each experimental condition as shown.

Histological sections taken before and after 1 hour incubation showed no substantial degenerative cytological changes in the marrow elements. Mitoses were still evident and all cell lineages were represented.

Crude protein was isolated, ${ }^{9}$ weighed, and counted in a Tracerlab flow counter having a background of $25-30 \mathrm{cpm}$. Sample counts were converted to disintegration per minute (DPM) using a standard $\mathrm{C}^{14}$ source from National Bureau of Standards.

Ribonucleic acid (RNA) and deoxyribonucleic acid (DNA) fractions were isolated by a modification of the Schmidt-Thannhauser technique. ${ }^{10}$ The incubated samples were frozen at $-70^{\circ} \mathrm{C}$, extracted and washed with $0.2 \mathrm{M}$ perchloric acid (PCA), and the lipid removed with successive washes of ethanol, ethanol-ether, and ether. The dried residue was incubated at $37^{\circ} \mathrm{C}$ for 1 hour in the presence of $1 \mathrm{~N} \mathrm{NaOH}$ and again reprecipitated with $0.2 \mathrm{M}$ PCA. The supernatant contained the RNA fraction; the washed precipitate, the DNA oligonucleotides. The separate fractions were

This paper appears in the Am. J. Physiology, 203,1962)

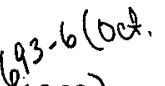

† Present address: New England Medical Center, Boston, Massachusetts. 
then adsorbed on Norite $\mathrm{A}$, eluted, brought to dryness, and each hydrolyzed to the constituent bases with 70 per cent PCA at $100^{\circ} \mathrm{C}$ for 1 hour. The bases were isolated by two-dimensional descending chromatography on Whatman No. 1 paper, using in the first dimension an isopropanol- $\mathrm{HCl}$ mixture (isopropanol-340 ml, concentrated $\mathrm{HCl}-82 \mathrm{ml}$, water to make $500 \mathrm{ml}$ ) for 24 hours and in the second dimension an $\underline{n}$-butanol- $\mathrm{NH}_{3}$ mixture (86 per cent vol/vol $\underline{n}$-butanolwater with enough concentrated $\mathrm{NH}_{4} \mathrm{OH}$ added to the liquid in the bottom of the tank to make 5 per cent of total solvent) for 12 hours. $R_{f}$ values obtained from a known mixture of bases, and from the hydrolyzed nucleic acids, approximated closely the published values. ${ }^{11}$ Each base was located on the paper under an ultraviolet lamp and eluted (by incubating at room temperature for 18 hours in $1 \mathrm{~N} \mathrm{HCl}$ ); the extinction coefficient of each was measured on a Zeiss spectrophotometer (M-QII) at 250, 260, and 280 millimicrons. The ratios of extinction coefficients agreed closely with those reported in the literature. ${ }^{12}$ Recovery of adenosine from known mixtures of bases was 95-100 per cent.

Radioactivity of adenine was estimated in a thin window counter using P-10 gas. Background was 5-7 cpm and sufficient counts were totaled to achieve a 5 per cent standard error level; these were converted to DPM as above.

Crystalline zinc insulin (Lilly, Lot No. 657501) obtained through the kindness of Mr. G. B. Walden, was dissolved in $0.003 \mathrm{~N} \mathrm{HCl}$ to give a stock solution of 1.0 international unit $/ \mathrm{ml}$ and stored at $4^{\circ}$ not longer than 3 months. Inactivated insulin was prepared by addition of an equal volume of $0.2 \mathrm{~N} \mathrm{NaOH}$ and incubation for 3 hours at $50^{\circ} \mathrm{C}$ with mild agitation. Both preparations were diluted to the desired final concentrations in the buffer.

Table 1

THE EFFECT OF INSULIN ON HISTIDINE-2(ring)-C ${ }^{14}$. INCORPORATION INTO PROTEIN

\begin{tabular}{c|c|c|c|c}
\hline $\begin{array}{c}\text { Exp. } \\
\text { No. }\end{array}$ & $\mathrm{N}$ & $\begin{array}{c}\text { Control } \\
\text { DPM/mg protein }\end{array}$ & $\begin{array}{c}\text { With insulin, } \\
10^{-2} \text { U/ml } \\
\text { DPM/mg protein }\end{array}$ & $\mathrm{P}^{*}$ \\
\hline 1. & 3 & $5251 \pm 53$ & $6811 \pm 61$ & 0.001 \\
2 & 6 & $3528 \pm 118$ & $4329 \pm 129$ & 0.001 \\
3 & 6 & $8282 \pm 129$ & $10668 \pm 395$ & 0.001 \\
& & & $8160 \pm 260$ & N.S. \\
4 & 3 & $5105 \pm 128$ & $6292 \pm 59$ & 0.001 \\
5 & 3 & $4902 \pm 249$ & $6234 \pm 110$ & 0.01 \\
10 & 3 & $4293 \pm 34$ & $5415 \pm 584$ & N.S. \\
$9 \ddagger$ & 4 & $2669 \pm 90$ & $3320 \pm 82$ & 0.001 \\
\hline
\end{tabular}

* In this and the following tables, each experimental value is the mean \pm standard error of the mean for the number $(\mathrm{N})$ of tissue samples in each of the control and hormone groups. The probability (P) of the difference arising by chance has been calculated by the $t$ test (25); the $P$ values are included as an aid in appraising the significance of the differences; N.S. = not significant.

$\dagger_{\text {Test }}$ made with alkali-inactivated insulin.

${ }_{\text {Glycine-2-C }}{ }^{14}$ used instead of histidine as labeled amino acid. 
L-thyroxine, 3,5,3'-triiodo-L-thyronine, and 3,5-diiodo-L-thyronine were obtained from Sigma Chemical Company. Stock solutions $(0.02 \mathrm{M})$ were prepared in $0.025 \mathrm{~N} \mathrm{NaOH}$ and diluted to the desired final concentration in the buffer; control flasks contained $0.025 \mathrm{~N} \mathrm{NaOH}$ similarly diluted.

L-histidine-2(ring)- $\mathrm{C}^{14} \cdot(2.62 \mathrm{mc} / \mathrm{mM})$ was obtained from Nuclear Chicago Corporation, glycine $(1.04 \mathrm{mc} / \mathrm{mM})$ and $\mathrm{D}$-glucose-U-C ${ }^{14}(1 \mathrm{mc} / \mathrm{mM})$ from Volk Radiochemical Corporation, and adenosine-8- $\mathrm{C}^{14}(5.0 \mathrm{mc} / \mathrm{mM})$ from Schwartz Bioresearch, Inc.

\section{RESULTS}

Amino acid incorporation. Insulin, $10^{-2}$ units $/ \mathrm{ml}$, increased the incorporation of histidine2 (ring) $-\mathrm{C}^{14}$ into protein (Table 1 ), the average stimulation being $26.0 \pm 1.4$ per cent (mean \pm S.E.). If the $\log$ of insulin concentration was plotted against the increase in incorporation, the values tended to lie along a straight line (Figure 1). Insulin which had been treated with alkali to destroy hypoglycemic activity was inactive in this system (Table 1, exp. 3).

Thyroxine also stiniulated amino acid incorporation (Table 2). There was an optimum concentration $\left(10^{-7} \mathrm{M}\right.$ ) at which incorporation was maximal (Figure 2). Triiodothyronine also gave a marked stimulation; under the same conditions, the effect of diiodothyronine was not statisti-

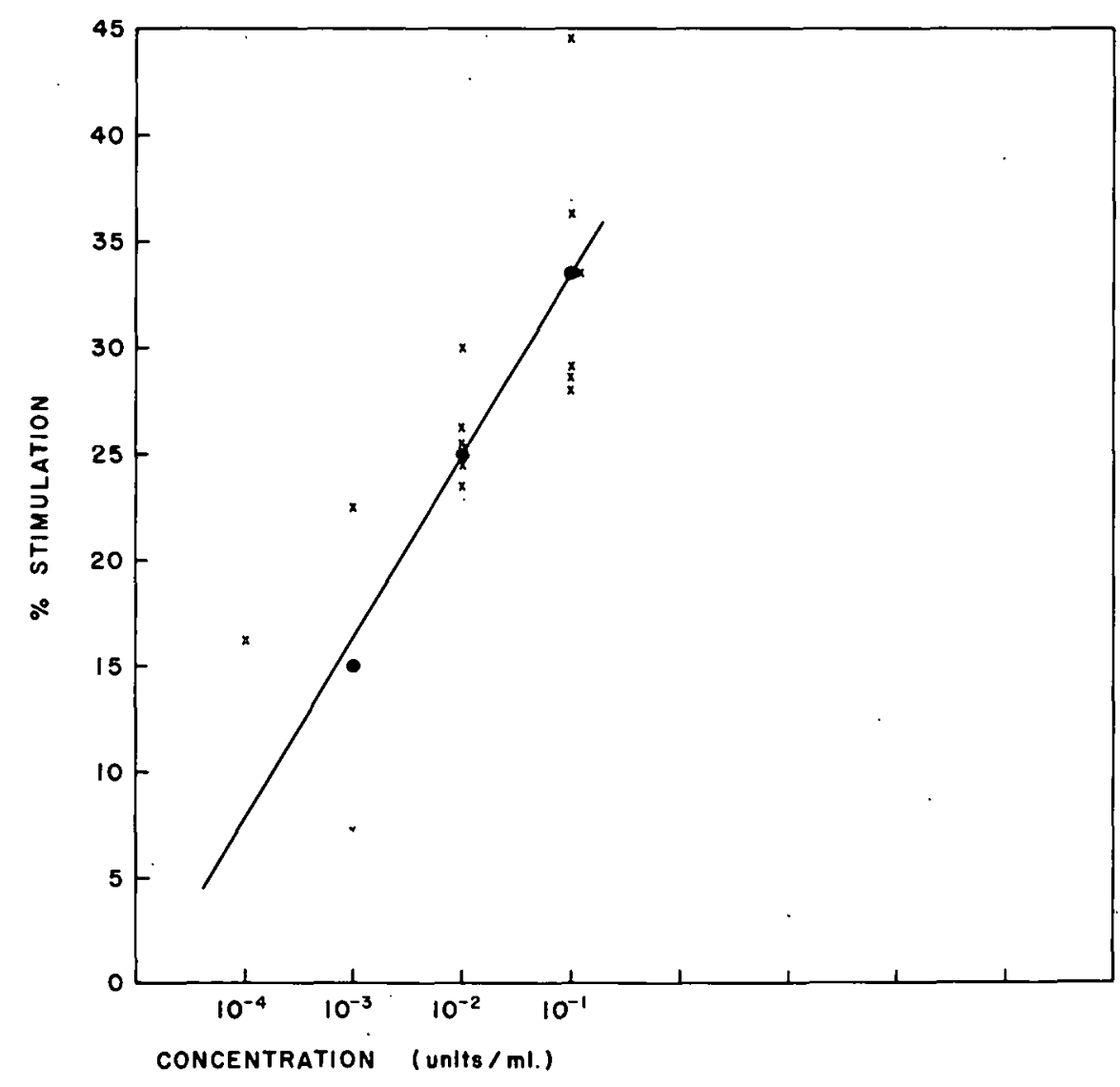

Figure 1. Percentage stimulation by insulin of histidine $a-C^{14}$ incorporation into bone marrow protein in vitro. (Control = base line.) $\bullet$ represents mean of all experiments. $X$ represents individual experiments. 
Table 2

THE EFFECT OF THYROXNE, TRIIODOTHYRONINE, AND DIIODOTHYRONINE ON HISTIDINE-2(ring)-C ${ }^{14}$ INCORPORATION INTO PROTEIN

\begin{tabular}{|c|c|c|c|c|c|}
\hline $\begin{array}{l}\text { Exp. } \\
\text { No. }\end{array}$ & $\mathrm{N}$ & $\begin{array}{l}\text { Addition to } \\
\text { medium }\end{array}$ & $\begin{array}{l}\text { Concentration, } \\
\text { milcromoles per } 1 \text {. }\end{array}$ & $\begin{array}{l}\text { Radioactivity } \\
\text { incorporated, } \\
\text { DPM/mg protein }\end{array}$ & 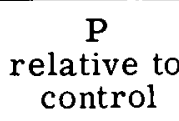 \\
\hline \multirow[t]{3}{*}{4} & 3 & Control. & 0 & $5105 \pm 128$ & \\
\hline & 3 & Thy roxine & 0.5 & $6898 \pm 402$ & 0.02 \\
\hline & 3 & Triiodothy ronine & 0.5 & $6588 \pm 142$ & 0.002 \\
\hline \multirow[t]{2}{*}{5} & 3 & Control & 0 & $4902 \pm 249$ & \\
\hline & 3 & Thyroxine & 0.1 & $6014 \pm 77$ & 0.02 \\
\hline \multirow[t]{2}{*}{6} & 3 & Control & 0 & $3550 \pm 96$ & \\
\hline & 3 & Thyroxine & 0.1 & $5462 \pm 439$ & 0.02 \\
\hline \multirow[t]{3}{*}{7} & 6 & Control & 0 & $4908 \pm 245$ & \\
\hline & 6 & Throxine & 0.1 & $7196 \pm 229$ & 0.001 \\
\hline & 6 & Diiodothyronine & 0.1 & $5366 \pm 463$ & 0.40 \\
\hline \multirow[t]{2}{*}{8} & 3 & Control & 0 & $3292 \pm 219$ & \\
\hline & 3 & Thyroxine & 0.1 & $4781 \pm 190$ & 0.007 \\
\hline
\end{tabular}

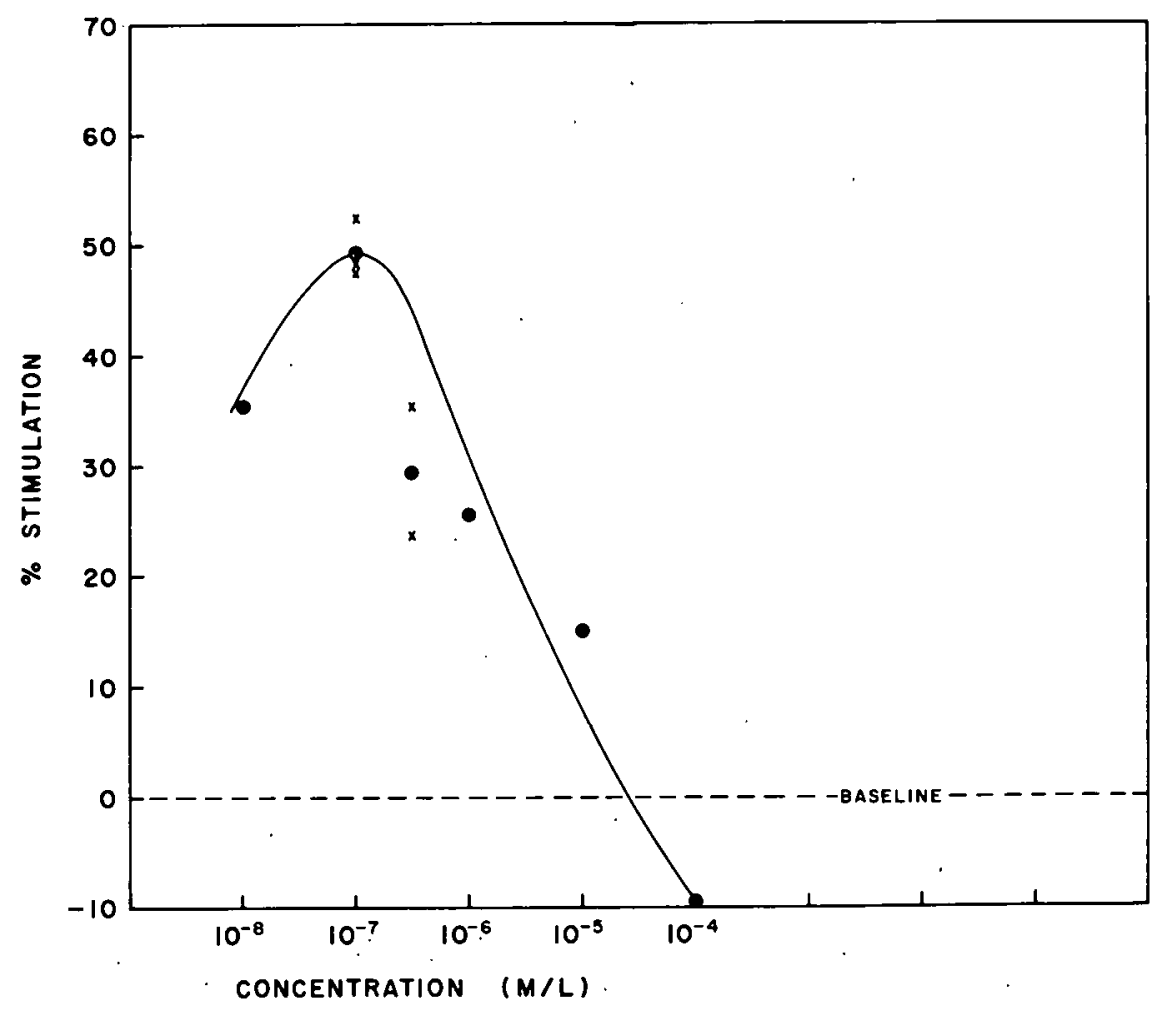

Figure 2. Percentage stimulation by thyroxine of histidinea-C 14 incorporation into bone marrow protein in vitro. (Control incubation = base line.) $\bullet$ represents mean of several experiments. $\mathrm{X}$ represents individual experiments. 
cally significant (Table 2). Somewhat similar phenomena have been observed by Sokoloff and Kaufman, ${ }^{13}$ who measured effects of thyroxine on amino acid incorporation into protein of rat liver homogenate; they report an optimum in vitro concentration of $10^{-4} \mathrm{M}$ with an average stimulation of 80 per cent; triiodothyronine was approximately as active as thyroxine.

Incorporation of precursers into nucleic acids. In bone marrow the incorporation of $\mathrm{C}^{14}$ from nucleotides into RNA or DNA has been reported to be relatively rapid, ${ }^{14-16}$ whereas the synthesis of purines from precursors is relatively slow. $15-24$

The relation of insulin and thyroxine to these processes has now been explored with the in vitro bone marrow system.

Insulin increased the incorporation of radioactivity from adenosine-8- $\mathrm{C}^{14}$ into nucleic acidadenine. The effect on incorporation of $\mathrm{C}^{14}$ from glycine-2- $\mathrm{C}^{14}$ was variable and, in every case, quantitatively very small as compared to those observed with adenosine-8- $\mathrm{C}^{14}$ (Table 3 ).

In contrast, the major effect of thyroxine was to stimulate incorporation of $\mathrm{C}^{14}$ from glycine into nucleic acid-adenine; there was no consistent stimulation of incorporation of adenosine-8$\mathrm{C}^{14}$ into nucleic acid (Table 4). These observations raise the interesting possibility that the anabolic effects of thyroxine on bone marrow may arise in part from stimulation of purine synthesis.

The author is indebted to Dr. M. E. Krahl for a number of suggestions.

Table 3

THE EFFECT OF INSULIN ON INCORPORATION OF PRECURSORS INTO NUCLEIC ACIDS. EACH EXPERIMENTAL NUMBER IS THE MEAN OF TRIPLICATE SAMPLES

\begin{tabular}{|c|c|c|c|c|c|c|c|}
\hline \multirow{2}{*}{$\begin{array}{l}\text { Exp. } \\
\text { No. }\end{array}$} & \multirow[b]{2}{*}{ Precursor } & \multirow{2}{*}{$\begin{array}{c}\text { Incubation } \\
\text { time } \\
\text { hours }\end{array}$} & \multirow{2}{*}{$\begin{array}{c}\text { Insulin } \\
10^{-2} \mathrm{U} / \mathrm{ml}\end{array}$} & \multicolumn{2}{|c|}{$\mathrm{RNA}^{*}$} & \multicolumn{2}{|l|}{ DNA } \\
\hline & & & & $\frac{\mu \mu \text { Mole } C^{14}}{\text { M Mole } A}$ & $\mathrm{p}^{\dagger}$ & $\begin{array}{l}\mu \mu \text { Mole } C^{14} \\
\mu \text { Mole } A\end{array}$ & $\mathbf{p}^{\dagger}$ \\
\hline \multirow[t]{2}{*}{11} & Glycine-2-C ${ }^{14}$ & 1 & 0 & $0.09 \pm 0.03$ & & $0.16 \pm 0.06$ & \\
\hline & & 1 & + & $0.31 \pm 0.06$ & 0.03 & $0.09 \pm 0.09$ & N.S. \\
\hline \multirow[t]{3}{*}{13} & Glycine-2-C $\mathrm{C}^{14}$ & 0 & 0 & & & $0.01 \pm 0.01$ & \\
\hline & & 1 & 0 & $0.05 \pm 0.02$ & & $0.07 \pm 0.02$ & \\
\hline & & 1 & + & $0.33 \pm 0.06$ & 0.02 & $0.27 \pm 0.07$ & 0.06 \\
\hline \multirow[t]{3}{*}{12} & Adenosine-8- $C^{14}$ & 0 & 0 & & & $0.53 \pm 0.10$ & \\
\hline & & 1 & 0 & $3.78 \pm 0.09$ & & $1.44 \pm 0.03$ & \\
\hline & & 1 & + & $5.96 \pm 0.18$ & 0.001 & $2.14 \pm 0.15$ & 0.01 \\
\hline \multirow[t]{3}{*}{13} & Adenosine-8-C $\mathrm{C}^{14}$ & 0 & 0 & $0.06 \pm 0.02$ & & $0.07 \pm 0.03$ & \\
\hline & & 1 & 0 & $2.03 \pm 0.06$ & & $1.13 \pm 0.17$ & \\
\hline & & 1 & + & $6.06 \pm 0.16$ & 0.001 & $2.60 \pm 0.26$ & 0.01 \\
\hline
\end{tabular}

*Values are expressed as micro-micromoles $\mathrm{C}^{14}$ (calculated from specific radioactivity of precursor) per millimicromole adenine (as determined spectrophotometrically in adenine sample eluted from chromatogram).

${ }^{\dagger} \mathrm{P}$ values are calculated relative to samples incubated concurrently without added hormone. 
Table 4

THE EFFECT OF THYROXINE ON INCORPORATION OF PRECURSORS INTO NUCLEIC ACIDS. EACH EXPERIMENTAL NUMBER IS THE MEAN OF TRIPLICATE SAMPLES*

\begin{tabular}{|c|c|c|c|c|c|c|c|}
\hline \multirow[b]{2}{*}{$\begin{array}{c}\text { Exp. } \\
\text { No. }\end{array}$} & \multirow[b]{2}{*}{ Precursor } & \multirow{2}{*}{$\begin{array}{c}\text { Incubation } \\
\text { time } \\
\text { hours }\end{array}$} & \multirow{2}{*}{$\begin{array}{c}\text { Thyroxine } \\
0.1 \mu \mathrm{M} \\
\text { per liter }\end{array}$} & \multicolumn{2}{|l|}{ RNA } & \multicolumn{2}{|l|}{ DNA } \\
\hline & & & & $\frac{\mu \mu \text { Mole } C^{14}}{\text { M } \mu \text { Mole } A}$ & $\mathbf{P}$ & $\frac{\mu \mu \text { Mole C }}{\text { M Mole } A}$ & $\mathbf{P}$ \\
\hline \multirow[t]{2}{*}{11} & Glyrine-2-r. 14 & 1 & 0 & $0.00 \pm 0.03$ & & $0.16 \pm 0.06$ & \\
\hline & & 1 & + & $2.23 \pm 0.45$ & 0.01 & $0.77 \pm 0.11$ & 0.01 \\
\hline \multirow[t]{3}{*}{13} & Glycine-2-C ${ }^{14}$ & 0 & 0 & & & $0.01 \pm 0.01$ & \\
\hline & & 1 & 0 & $0.05 \pm 0.02$ & & $0.07 \pm 0.02$ & \\
\hline & & 1 & + & $0.90 \pm 0.07$ & 0.001 & $1.05 \pm 0.11$ & 0.001 \\
\hline \multirow[t]{3}{*}{12} & Adenosine-8-C $C^{14}$ & 0 & 0 & & & $0.53 \pm 0.10$ & \\
\hline & & 1 & 0 & $3.78 \pm 0.09$ & & $1.44 \pm 0.03$ & \\
\hline & & 1 & + & $3.16 \pm 0.35$ & N.S. & $1.43 \pm 0.15$ & N.S. \\
\hline \multirow[t]{3}{*}{13} & Adenosine-8-C $C^{14}$ & 0 & 0 & $0.06 \pm 0.02$ & & $0.07 \pm 0.03$ & \\
\hline & & 1 & 0 & $2.03 \pm 0.06$ & & $1.13+0.17$ & \\
\hline & & 1 & + & $3.61 \pm 0.31$ & 0.02 & $1.22 \pm 0.18$ & N.S. \\
\hline
\end{tabular}

See Table 3 for explanatory footnotes.

\section{LITERATURE CITED}

1. Gordon, A. S. Rec. Prog. Hormone Res., 10:339, 1954.

2. Linman, J. W., and F. H. Bethell. Factors Controlling Erythropoiesis, Springfield, Ill.: C. C. Thomas Co., 1960, p. 10.

3. Carnot, P., and C. DeFlandre. Compt. rend. Acad. Sci., 143:384, 1906.

4. Plzak, L. F., W. Fried, L. O. Jacobson, and W. F. Bethard. J. Lab. Clin. Med., 46:671, 1953.

5. White, W. F., C. W. Gurney, E. Goldwasser, and L. O. Jacobson. Rec. Prog. Hormone Res., $16: 219,1960$.

6. Erslev, A. J. Blood, 10:954, 1955.

7. Wolstenholme, G. E. W., and M. O'Connor (Editors). Haemopoiesis. Cell Production and Its Regulation, Boston, Mass.: Little, Brown and Co., 1961.

8. Umbreit, W. W., R. H. Burris, and J. P. Stauffer. Manometric Techniques, Revised edition, Minneapolis, Minn.: Burgess Publishing Co., 1957.

9. Wool, I. G., and M. E. Krahl. Am. J. Physiol., 196:961, 1959.

10. Leslie, I. In The Nucleic Acids, Vol. II, E. Chargaff and J. N. Davidson, Editors, New York: Academic Press, Inc., 1955.

11. Wyatt, G. R. In The Nucleic Acids, Vol. I, E. Chargaff and J. N. Davidson, Editors, New York: Academic Press, Inc., 1955. 
12. "Properties of The Nucleic Acid Derivatives." Table published by California Foundation Biochemistry Research, 3rd Revision, Los Angeles, Calif., 1958.

13. Sokoloff, L., and S. Kaufman. Science, 129:569, 1959.

14. Thomas, E. D., and H. L. Lochte, Jr. Blood, 12:1086, 1957.

15. Lajtha, L. G. In The Kinetics of Cellular Proliferation, F. Stohlman, Jr., Editor, New York: Grune and Stratton, 1959.

16. Thomson, R. Y., R. M. S. Smellie, and J. N. Davidson. Biochim. et Biophys. Acta., 29:308, 1958.

17. Lajtha, L. G. Nature, 174:1013, 1954.

18. Smellie, R. M. S., R. Y. Thomson, and J. N. Davidson. Biochim. et Biophys. Acta., 29:59, 1958.

19. Thomson, R. Y., G. Ricceri, and M. Perzetta. Biochim. et Biophys. Acta., 45:87, 1960.

20. Totter, J. R., and A. N. Best. Arch. Biochem. Biophys., 54:318, 1955.

21. Weissman, S. M., R. M. S. Smellie, and J. Paul. Biochim. et Biophys. Acta., 45:101, 1960.

22. Gray, E. D., S. M. Reissman, J. Richards, D. Bell, H. M. Ken, R. M. S. Smellie, and J. N. Davidson. Biochim. et Biophys. Acta., 45:111, 1960.

23. Lajtha, L. G., and J. R. Vane. Nature, 182:190, 1958.

24. Lajtha, L. G., W. D. Noyes, and R. Oliver. Expti. Cell. Res., 16:471, 1959.

25. Fisher, R. A. Statistical Methods for Research Workers, London: Oliver and Boyd, 1941. 


\title{
BIOCHEMICAL_STUDIES ON SPONTANEOUS CARCINOGENESIS: IN VIVO EFFECTS OF HORMONAL CHANGES ON C3H MICE BEARING HORMONE- DEPENDENT MAMMARY CARCINOMA*
}

By

\author{
G. T. Okita and E. A. Ezz ${ }^{\dagger}$
}

In a previous report ${ }^{1}$ we described in vivo changes in the metabolism of various $\mathrm{C}^{14}$-labeled biochemical intermediates in precancerous and spontaneous mammary tumor-bearing C3H mice. Important biochemical changes noted were: 1) the occurrence of altered metabolic patterns in precancerous mice before the onset of tumor formation which were similar to those existing in tumor-bearing animals; and 2) the in vivo demonstration of a decrease in direct oxidative metabolism of glucose with an increase in glycolysis. These metabolic alterations were demonstrated by utilizing an instrument developed in our laboratory and previously described. ${ }^{1,2}$

Since spontaneous mammary tumors in $\mathrm{C} 3 \mathrm{H}$ mice were demonstrated to be hormonally dependent, further in vivo studies were conducted to determine the effects of hormonal changes on the altered metabolic patterns which exist in precancerous and tumor-bearing animals. The present communication describes the effects of ovariectomy and administration of testosterone and estradiol on the oxidation of glucose-1-C $\mathrm{C}^{14}$ and glucose-6-C $\mathrm{C}^{14}$ to $\mathrm{C}^{14} \mathrm{O}_{2}$ in control, precancerous, and tumor-bearing $\mathrm{C} 3 \mathrm{H}$ mice.

\section{EXPERIMENTAL}

The respiratory $\mathrm{C}^{14} \mathrm{O}_{2}$ monitor has been described previously ${ }^{1}$ and is a slight modification of an earlier design used in human studies. ${ }^{2}$ Briefly, it measures continuously $\mathrm{C}^{14} \mathrm{O}_{2}$ radioactivity in expired air, $\mathrm{CO}_{2}$ levels, and relative specific activity $\left(\mathrm{C}^{14} / \mathrm{C}^{12}\right)$ of expired $\mathrm{C}^{14} \mathrm{O}_{2}$ as computed by a ratio-analyzer. All data are printed out on a four-channel recording millivoltmeter.

The animals utilized in this study were female $\mathrm{C} 3 \mathrm{H}$ mice obtained from Cumberland View Farms and selected because this strain has over a 95 per cent incidence of spontaneous mammary adenocarcinoma. Hormonal dependence was established by noting regression of mammary tumors following ovariectomy. The following experimental groups were studied: a) control virgin females, approximately 3 months old, b) "precancerous" multiparous retired exbreeders, approximately 12 months old, and c) single tumor-bearing exbreeders, also approximately 12 months old. The precancerous nature of $\mathrm{C} 3 \mathrm{H}$ mice is well documented ${ }^{3,4}$ since they have welldefined hyperplastic alveolar nodules in their mammary glands which are regarded as precancerous lesions. Histological examination of our $\mathrm{C} 3 \mathrm{H}$ mice indicates that after $5-6$ months of age mammary tumor milk factor bearing animals all have hyperplastic nodules whether they are virgin or non-virgin females. However, 3 months old factor-bearing mice as well as nonfactor bearing $\mathrm{C} 3 \mathrm{H}$ mice of various ages generally do not. Only mice bearing firm, non-necrotic

${ }^{*}$ This paper was presented before the VIII International Cancer Congress, Moscow, U.S.S.R., August 1962, and will appear in the proceedings of the conference.

${ }^{\dagger}$ Present address: University of Alexandria, Faculty of Medicine, Alexandria, U. A. R. 
and non-deteriorating tumors between 0.5 to $1.5 \mathrm{~cm}$ in diameter were used. The mammary tumor milk factor is common to all groups except where indicated. For ovariectomized animals, metabolic studies were conducted a week after operation. Estradiol-17 $\beta$ and testosterone were administered intraperitoneally at doses of $0.2 \mu \mathrm{g} / \mathrm{gram}$ and $0.03 \mathrm{mg} / \mathrm{gram}$ body weight, respectively, two hours before administration of $\mathrm{C}^{14}$-labeled intermediates.

All $\mathrm{C}^{14}$-labeled intermediates were obtained from commercial sources and were reassayed for radiochemical purity and radioactivity. In order to prevent bacterial decomposition sterile solutions of the labeled intermediates were prepared in normal saline and stored in the freezer when not in use. All injections were made intraperitoneally to mice fasted 8-14 hours. Immediately after injection, the mice were returned to the animal chamber for continuous recording of expiratory $\mathrm{C}^{14} \mathrm{O}_{2}, \mathrm{CO}_{2}$ and specific activity of $\mathrm{C}^{14} \mathrm{O}_{2}$. Analysis of the experimental data has been described previously. 1

\section{RESULTS AND DISCUSSION}

Effect of ovariectomy. In a previous communication, ${ }^{1}$ altered glucosc metabolism was reported for precancerous and spontaneous mammary tumor-bearing $\mathrm{C} 3 \mathrm{H}$ mice as evidenced by a decrease in oxidation of glucose-1-C $\mathrm{C}^{14}$ and an increase in oxidation of glucose-6-C $\mathrm{C}^{14}$ to respiratory $\mathrm{C}^{14} \mathrm{O}_{2}$ when compared to control animals. Since spontaneous mammary tumors in these mice were demonstrated to be hormone dependent, the effects of ovariectomy in further changing the altered metabolic patterns observed in precancerous and tumor mice was investigated. The in vivo effects of ovariectomy on the oxidation of glucose-1-C ${ }^{14}$ and glucose-6-C ${ }^{14}$ to respiratory $\mathrm{C}^{14} \mathrm{O}_{2}$ for the various experimental groups are shown in Table 1. Ovariectomy significantly decreases the elevated oxidation of glucose-6-C $\mathrm{C}^{14}$ in precancerous and tumor animals to levels found in non-precancerous, non-tumor virgin control mice. This is further demonstrated by the increase in depressed G-1/G-6 ratios to control values of 1.39 . However, ovariectomy has little or no effect on glucose-1-C $\mathrm{C}^{14}$ metabolism in the three experimental groups. It was interesting that ovariectomy had no effect on the metabolism of glucose-6-C ${ }^{14}$ in virgin animals. However, this may not be surprising since 3-month-old virgins have low hormonal titers which would not be appreciably affected by ovariectomy.

Effect of testosterone. Table 2 shows that testosterone exerts a similar effect to ovariectomy on the metabolism of $C^{14}$-labeled glucose in tumor-bearing mice. Glucose-6- $C^{14}$ oxidation is reduced from 12.8 to $8.9(\mathrm{P}<0.01)$ which is in good agreement with the reduced values for ovariectomized tumor bearers (8.6) and virgin controls (9.9). The G-1/G-6 ratio is also similar for testosterone-treated tumor-bearers and virgin controls. These findings suggest that ovariectomy and testosterone therapy tend to correct metabolic alterations observed in precancerous and tumor-bearing $\mathrm{C} 3 \mathrm{H}$ mice, and that the biochemical mechanism underlying clinical treatment of mammary carcinoma by ovariectomy and testosterone therapy may be similar.

Effect of estradiol. Since the biochemical effects reported above appear to be related to removal of estrogen source and to estrogen antagonism, respectively, the effects of estradiol on glucose oxidation was investigated. If one can assume that the observed effects may be related to estrogens, then a priori, it would be expected that administration of estrogen to control animals would decrease the oxidation of glucose-1-C $C^{14}$, and increase oxidation of glucose-6-C ${ }^{14}$, as demonstrated in precancerous and tumor-bearing $\mathrm{C} 3 \mathrm{H}$ mice. For these experiments, factorfree exbreeder $\mathrm{C} 3 \mathrm{H}$ mice were used as non-tumor, non-precancerous controls instead of young 
Table 1

EFFECTS OF OVARIECTOMY ON IN VIVO OXIDATION OF GLUCOSE-1-C ${ }^{14}$ AND GLUCOSE-6-C ${ }^{14} \mathrm{~J}_{2}$ IN C3H MICE

\begin{tabular}{|c|c|c|c|c|c|c|}
\hline \multirow{2}{*}{$\begin{array}{l}\text { Experimental } \\
\text { groups }\end{array}$} & \multicolumn{2}{|c|}{$\begin{array}{c}\text { Glucose-1-C } \mathrm{C}^{14} \\
\text { (per cent oxidized to } \mathrm{C}^{14} \mathrm{O}_{2} \text { ) } \\
0-60 \text { minutes }\end{array}$} & \multicolumn{2}{|c|}{$\begin{array}{c}\text { Glucose-6-C } \mathrm{C}^{14} \\
\text { (per cent oxidized to } \mathrm{C}^{14} \mathrm{O}_{2} \text { ) } \\
0-60 \text { minutes }\end{array}$} & \multicolumn{2}{|c|}{$\begin{array}{c}\text { G-1/G-6 } \\
\text { (ratio of per cent oxidized) }\end{array}$} \\
\hline & $\begin{array}{l}\text { Non-ovariectomized } \\
(\mathrm{N})\end{array}$ & $\begin{array}{l}\text { Ovariectomized } \\
(\mathrm{N})\end{array}$ & $\begin{array}{l}\text { Non-ovariectomized } \\
(\mathrm{N})\end{array}$ & $\begin{array}{l}\text { Ovariectomized } \\
(\mathrm{N})\end{array}$ & Non-ovariectomized & Ovariectomized \\
\hline Virgin controls & $13.8 \pm \underset{(11)}{1.4 \mathrm{~S} . \mathrm{D} .}$ & $13.0 \pm \underset{(4)}{0.3}$ & $9.9 \pm \underset{(11)}{0.8}$ & $9.5 \pm \underset{(5)}{0.7}$ & $1.3:$ & 1.37 \\
\hline $\begin{array}{l}\text { "Precancerous" } \\
\text { exbreeders }\end{array}$ & $\begin{array}{l}12.7 \pm 1.4 \\
(12) \\
\mathrm{p}^{+}<0.05\end{array}$ & $15.3 \pm \underset{(5)}{4.2}$ & $\begin{array}{l}13.3 \pm 2.6 \\
(14) \\
\mathrm{P}^{+}<0.005\end{array}$ & $\begin{array}{l}9.8 \pm \underset{(5)}{0.1} \\
\mathrm{P}^{*}<0.005\end{array}$ & 0.95 & 1.56 \\
\hline $\begin{array}{l}\text { Tumor-bearing } \\
\text { exbreeders }\end{array}$ & $\begin{array}{l}11.1 \pm 1.6 \\
(15) \\
P^{+}<0.005\end{array}$ & $12.1 \pm 2.0$ & $\begin{array}{l}12.8 \pm 2.5 \\
(8) \\
\mathrm{P}^{+}<0.005\end{array}$ & $\begin{array}{l}8.6 \pm 1.4 \\
(4) \\
\mathrm{P}^{*}<0.01\end{array}$ & $0.8^{m}$ & 1.41 \\
\hline
\end{tabular}

$P$ values for differences in mean values between various groups and virgins of non-ovariectomized series.

* $P$ values for differences in mean values between ovariectomized and non-ovariectomized controls. 
Table 2

EFFECTS OF TESTOSTERONE ON IN VIVO OXIDATION OF GLUCOSE-1-C ${ }^{14}$ AND GLUCOSE-6-C ${ }^{14}$ TO $\mathrm{C}^{14} \mathrm{O}_{2}$ IN TUMOR-BEARING C3H MICE

\begin{tabular}{|c|c|c|c|}
\hline $\begin{array}{l}\text { Experimental } \\
\text { groups }\end{array}$ & $\begin{array}{c}\text { Glucose-1-C } \mathrm{C}^{14} \\
\text { (per cent oxidized to } \mathrm{C}^{14} \mathrm{O}_{2} \text { ) } \\
0-60 \text { minutes }\end{array}$ & $\begin{array}{c}\text { Glucose-6- } \mathrm{C}^{14} \\
\text { (per cent oxidized to } \mathrm{C}^{14} \mathrm{O}_{2} \text { ) } \\
0-60 \text { minutes }\end{array}$ & $\begin{array}{c}\text { G-1/G-6 } \\
\text { (ratio of per } \\
\text { cent oxidized) }\end{array}$ \\
\hline $\begin{array}{l}\text { Tumor } \\
\text { exbreeders }\end{array}$ & $11.1 \pm \underset{(15)}{1.6}$ S.D. & $\begin{array}{r}12.8 \pm 2.5 \\
(8)\end{array}$ & 0.87 \\
\hline $\begin{array}{l}\text { Tumor-bearing } \\
\text { exbreeders } \\
\text { + testosterone }\end{array}$ & $13.9 \pm \underset{(6)}{4.4}$ & $\begin{array}{r}8.9 \pm \frac{1.4}{(4)} \\
\mathrm{P}^{+}<0.01\end{array}$ & 1.55 \\
\hline Virgin controls & $13.8 \pm \frac{1.4}{(11)}$ & $\begin{array}{l}9.9 \pm \underset{(11)}{0.8} \\
(11)\end{array}$ & 1.39 \\
\hline
\end{tabular}
mice.

" $P$ value for difference in mean value between testosterone-treated and nun-treated tumor

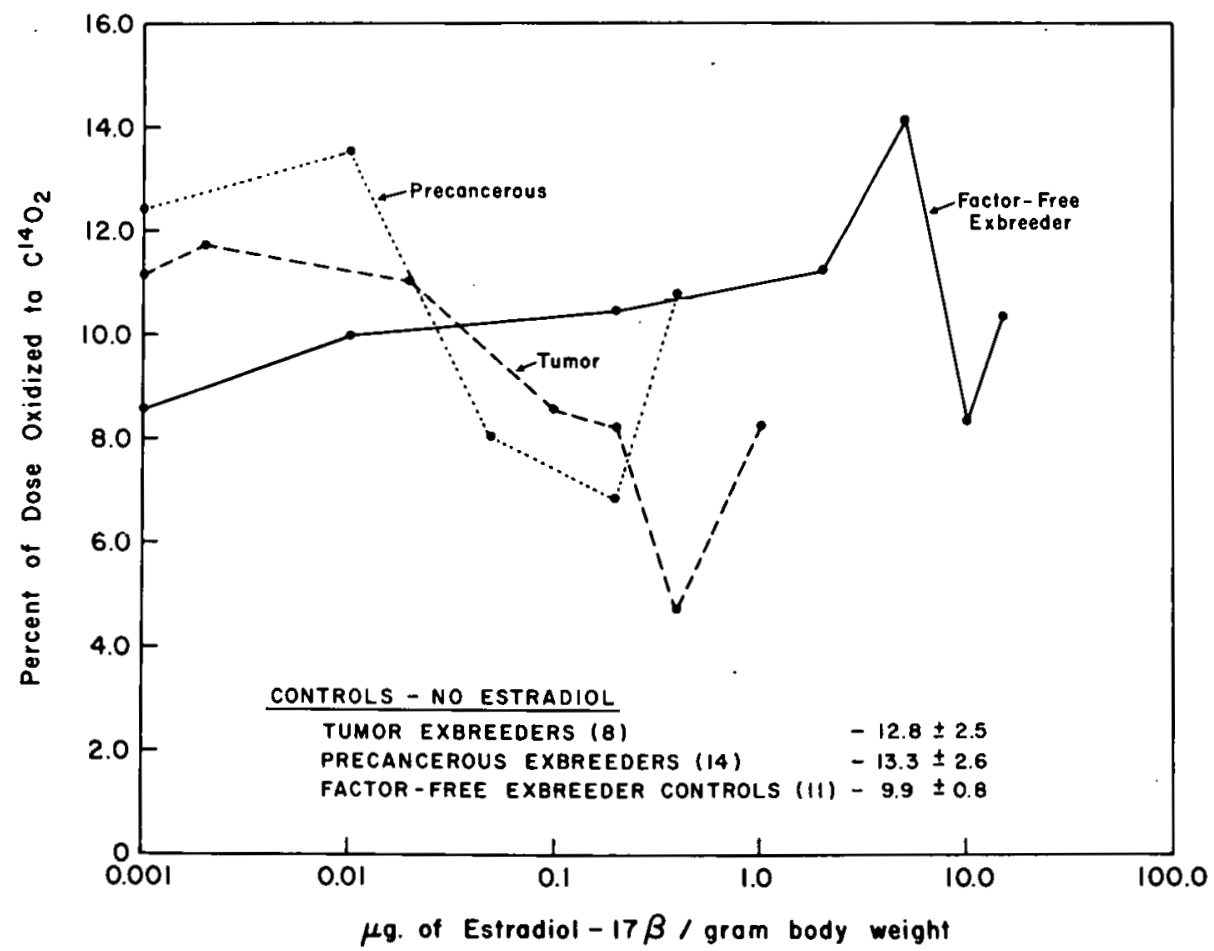

Figure 1. Dose-response curves of estradiol-17 $\beta$ on in vivo oxidation of glucose-6-C $\mathrm{C}^{14}$ to $\mathrm{C}^{14} \mathrm{O}_{2}$.

virgins so that all animals would be under similar hormonal conditions with respect to multiple pregnancy. As shown in Table 3 the factor-free exbreeder control group exhibited a 25 per cent decrease in glucose-1-C $C^{14}$ oxidation $(P<0.005)$ and an insignificant increase in glucose-6- $C^{14}$ oxidation. For the precancerous and tumor groups, a small but significant decrease in metabolism of glucose-1-C $\mathrm{C}^{14}$ also was noted, while for glucose-6- $\mathrm{C}^{14}$, instead of an increase in oxida- 
Table 3

EFFECTS OF ESTRADIOL ON IN VIVO OXIDATION OF GLUCOSE-1-C ${ }^{14}$ AND GLUCOSE-6-C ${ }^{14}$ TO $\mathrm{C}^{14} \mathrm{O}_{2}$ IN C3H MICE

\begin{tabular}{|c|c|c|c|c|c|c|}
\hline \multirow{2}{*}{$\begin{array}{c}\text { Experimental } \\
\text { groups }\end{array}$} & \multicolumn{3}{|c|}{$\begin{array}{c}\text { Glucose-1- } \mathrm{C}^{14} \\
\text { (per cent oxidized to } \mathrm{C}^{14} \mathrm{O}_{2} \text { ) } \\
0-60 \text { minutes }\end{array}$} & \multicolumn{3}{|c|}{$\begin{array}{c}\text { Glucose-6- } \mathrm{C}^{14} \\
\text { (per cent oxidized to } \mathrm{C}^{14} \mathrm{O}_{2} \text { ) } \\
0-60 \text { minutes }\end{array}$} \\
\hline & Control & $\begin{array}{l}\text { Estradiol } \\
\text { treated* }\end{array}$ & $\begin{array}{l}\text { Per cent } \\
\text { change }\end{array}$ & Control & $\begin{array}{l}\text { Estradiol } \\
\text { treated* }\end{array}$ & $\begin{array}{l}\text { Per cent } \\
\text { change }\end{array}$ \\
\hline $\begin{array}{l}\text { Factor-free } \\
\text { exbreeder controls }\end{array}$ & $14.5 \pm \frac{1.2}{(4)}$ S.D. & $10.9 \pm \underset{(5)}{0.86}$ & $\begin{array}{l}-25 \% \\
\mathrm{P}<0.005\end{array}$ & $9.7 \pm \underset{(5)}{1.1}$ & $10.5 \pm \underset{(5)}{0.9}$ & $+7.6 \%$ \\
\hline $\begin{array}{l}\text { "Precancerous" } \\
\text { exbreeders }\end{array}$ & $12.7 \pm \frac{1.4}{(12)}$ & $11.0 \pm \frac{1.0}{(5)}$ & $\begin{array}{l}-13 \% \\
\mathrm{P}<0.005\end{array}$ & $13.3 \pm 2.6$ & $6.9=0.9$ & $\begin{array}{l}-48 \% \\
\mathrm{P}<0.005\end{array}$ \\
\hline $\begin{array}{l}\text { Tumor-bearing } \\
\text { exbreeders }\end{array}$ & $11.1 \pm \frac{1.6}{(15)}$ & $9.3 \pm \underset{(6)}{0.7}$ & $\begin{array}{l}-16 \% \\
\mathrm{P}<0.025\end{array}$ & $12.8 \pm 2.5$ & $8.3=\frac{1.4}{(5)}$ & $\begin{array}{l}-35 \% \\
\mathrm{P}<0.005\end{array}$ \\
\hline
\end{tabular}

${ }_{0.2 \mu}^{*}$ g estradiol-17f per gram administered I.P. 2 hours before $\mathrm{C}^{14}$-glucose administration. 
tion, a decrease was observed. On the assumption that the observed decrease in glucose-6-C $\mathrm{C}^{14}$ may be the result of an inhibitory phase of a diphasic action of estrogen, a dose-response experiment was conducted. As can be seen from the curves in Figure 1, at a dose of $0.2 \mu \mathrm{g} / \mathrm{gram}$ of estradiol the precancerous and tumor-bearing animals were on the inhibitory part of a polyphasic curve. Therefore, it appears that when doses of estradiol between $0.01-0.5 \mu \mathrm{g} / \mathrm{gm}$ are administered to both precancerous and tumor $\mathrm{C} 3 \mathrm{H}$ mice the rate of oxidation of glucose-6- $\mathrm{C}^{14}$ is decreased, whereas when doses less than $0.01 \mu \mathrm{g} / \mathrm{gm}$ are administered there is an increase in oxidation to $\mathrm{C}^{14} \mathrm{O}_{2}$. An unexpected finding was the approximately five hundred-fold increase in sensitivity of precancerous and tumor mice to the inhibitory effects of estradiol on glucose$6-\mathrm{C}^{14}$ oxidation in comparison to non-tumor, non-precancerous controls. Therefore, the results obtained from the present study suggest a biochemical correlation between mammary tumor carcinogenesis and hormonal influences on $\mathrm{C} 3 \mathrm{H}$ mice.

The authors wish to acknowledge Mr. William Gross for technical assistance during studies on the effects of estradiol on $\mathrm{C}^{14}$-glucose metabolism.

\section{LITERATURE CITED}

1. Ezz, E. A:, and G. T. Okita. Cancer Res. In press.

2. LeRoy, G. V., G. T. Okita, E. C. Tocus, and D. Charleston. Int. J. App'd. Radio and Isotopes, $7: 273,1960$.

3. Gardener, W. U., L. C. Strong, and C. M. Smith. Am. J. Cancer, 37:510, 1939.

4. Huseby, R. A., and J. J. Bittner: Cancer Res., 6:240, 1946. 


\section{STAFF PUBLICATIONS}

Blaisdell, R. K. Ionizing radiation and human leukemia. Postgraduate Medicine, 31(3):A-61, 1962 .

DeBersaques, J., and S. Rothman. Mechanism of keratin formation. Nature, 193:No. 4811, 147, 1962 .

DeGowin, R. L., D. Hofstra, and C. W. Gurney. A comparison of erythropoietin bioassays. Proc. Soc. Exptl. Biol. Med., 110:48, 1962.

Fisher, J. W. Effect of adrenalectomy on the erythropoietic response to sheep erythropoietin and cobalt. Endocrinology, 70(2):243, 1962.

Fisher, J. W., and J. J. Crook. Influence of several hormones on erythropoiesis and oxygen consumption in the hypophysectomized rat. Blood, 19(5):557, 1962.

Fitch, F. W. Immunohistochemical study of Ehrlich ascites tumor. Arch. Pathol., 73:144, 1962.

Fitch, F. W., J. Winebright, and P. V. Harper. Iodine-125 as a protein label in immunology. Science, 135:No. 3508, 1068, 1962.

Goepp, R., and F. Fitch. The effect of therapeutic and protective measures on "Oral Radiation Death" in mice (abstract). Radiation Research, 16(4): 1962.

Goepp, R., and F. Fitch. Pathological study of oral radiation death in mice. Radiation Research, $16(6): 833,1962$.

Griem, M. L., and K. Ranniger. Modification of the radiation effect on hair roots of the mouse by actinomycin. Radiation Research, 17(1):92, 1962.

Gunderson, C. H., D. Juras, M. F. La Via, and R. W. Wissler. Tissue and cellular changes associated with antibody formation in the rat spleen. J. Am. Med. Assoc., 180:1038, 1962.

Harper, P. V., G. Andros, K. Lathrop, W. Siemens, and L. Weiss. Metabolism of technetium$99^{\mathrm{m}}$ (abstract). Radiation Research, 16(4): 1962.

Jacobson, L. O., and M. Doyle, editors. Erythropoiesis, New York: Grune and Stratton, 1962.

Jefferson, E. H., A. C. Kienzle, and M. L. Griem. Microwave heating as an adjunct in the experimental control of tumors in mice. (Abstract.) Radiation Research, 16(4): 1962.

Lanzl, L. H., and J. W. J. Carpender. Adapted and expanded, Moving Field Radiation Therapy, by F. Wachsmann and G. Barth, Chicago: The University of Chicago Press, 1962 .

Mendel, G. A. Studies on the regulation of iron absorption. Proc. Inst. Med., Chicago, 24(4): 1962 .

Nakamoto, T., and S. B. Weiss. The biosynthesis of RNA: priming by polyribonucleotides. Proc. Nat. Acad. Sci., 48(5):880, 1962.

Necheles, T., J. Spratt, E. Ford, and E. Beutler. Effect of thyroid hormone on the pathways of glucose oxidation in the intact rat. Proc. Soc. Exptl. Biol. Med., 109:114, 1962.

Okita, G. T. On the use of expiratory ${ }^{14} \mathrm{CO}_{2}$ patterns as a pharmacological tool for studying the biochemical effects of drugs. Biochemical Pharmacology, 8(1): 1961 (abstract), New York: Pergamon Press.

Okita, G. T., and J. L. Spratt. Determination of radiotracer stability of tritium-labeled compounds in biological studies. In I.A.E.A. publication Tritium in the Physical and Biological Sciences, Volume II, Vienna, 1962, pp. 85-92. 
Palmer, R. H., P. B. Glickman, and A. Kappas. Pyrogenic and inflammatory properties of certain bile acids in man. J. Clin. Invest., 41(8):1573, 1962.

Rothman, S. Medical research in Africa. Arch. Dermatol., 85:311, 1962.

Rothman, S. Some remarks on Moricz Kaposi and on the history of Kaposi's sarcoma. Acta Union Internationale Contre le Cancer, 18(3):322, 1962.

Rothman, S. Remarks on sex, age and racial distribution of Kaposi's sarcoma and on possible pathogenetic factors. Acta Union Internationale Contre le Cancer, 18(3):326, 1962 .

Rothman, S. Some clinical aspects of Kaposi's sarcoma in the European and North American population. Acta Union Internationale Contre le Cancer, 18(3):364, 1962.

Sorensen, L. B. The pathogenesis of gout. Arch. Int. Med., 109:379, 1962.

Stone, M. J., K. Dzoga, and R. W. Wissler. Combined inhibitory effect of antitumor antibody and an oncolytic virus on the solid Ehrlich tumor. Lab. Invest., 11(4):306, 1962.

Thompson, J. S., E. L. Simmons, and D. Hofstra. Studies on the immunologic unresponsiveness during the secondary disease period of lethally irradiated mice protected by homologous bone narrow. J. Immunol., 89(1):62, 1862.

Tocus, E. C., G. T. Okita, J. P. Evans, and S. Mullan. The localization of octoiodofluorescein$I^{13} 1$ in human brain tumors. Cancer, 15(1):153, 1962.

Weiss, S. B. Biosynthesis of ribopolynucleotides. Federation Proceedings, 21(1):120, 1962. 